\title{
'TRUE DIRECTION' ASPECTS OF AESTHETICISM IN NEW ZEALAND (1880-1913)
}

LAURA ELIZABETH CAMPBELL

A thesis submitted in fulfilment of the requirements for the degree of Master of Arts in Art History

VICTORIA UNIVERSITY OF WELLINGTON

2016 


\section{CONTENTS}

$\begin{array}{ll}\text { Contents } & \text { ii }\end{array}$

$\begin{array}{ll}\text { Abstract } & \text { iii }\end{array}$

Acknowledgements iv

INTRODUCTION 1

1 THE ORIGINS OF AESTHETICISM: AN INTERNATIONAL 13 MOVEMENT

2 THE 'LOST' THOUGHTS OF AN ANTIPODEAN BUTTERFLY. 44 J. M. NAIRN’S ‘DECORATIVE ART’ LECTURE OF 1890

3 SEARCH FOR BEAUTY 'SOUTH OF THE LINE’: THE 81 ARTIST'S STUDIO AND THE ANTIPODEAN WOMAN

$\begin{array}{ll}\text { CONCLUSION } & 103\end{array}$

$\begin{array}{ll}\text { List of Plates } & 108\end{array}$

$\begin{array}{lr}\text { Plates } & 110\end{array}$

$\begin{array}{ll}\text { Bibliography } & 142\end{array}$

Appendix J. M. Nairn's 'Decorative Art' in Otago Witness (1890) 161 


\section{ABSTRACT}

This thesis examines aspects of Aestheticism in New Zealand. Despite the paucity of literature written on Aestheticism in colonial contexts, there is evidence that Aesthetic tendencies flourished in the art and literature of the 'South Seas'. Aestheticism in Australia and New Zealand has been categorised as 'insignificant' within national art histories, overlooking the complex ways whereby aspects of Aestheticism arrived in the antipodes through international exhibitions, touring theatre productions, academically trained artists from Europe, and dispersal through literature. It is a moment in our national art history that should be recognised. My research is the first comprehensive study of Aestheticism and its impact on applied art and the general lifestyles of artists and patrons in New Zealand.

With particular focus on James McLauchlan Nairn and Charles Frederick Goldie, this study revises the status of two New Zealand artists who have been viewed as representative of opposing artistic camps - Nairn, a bohemian promoting Impressionist and open air landscape practice, and Goldie, a painter of the 'Old World' tradition of academic instruction. I suggest the oppositional status that has been applied to these painters in New Zealand's art history is no more than a polemical device. By contrast, Aestheticism allows us to understand how both artists are not too dissimilar in certain aspects of their artistic ambition. They were both educated in Paris and this alone provided them with a sense of authority to dictate art and fashion when advising their upper-class clientele in New Zealand. My research has revealed how Nairn and Goldie inhabited similar social circles, in Wellington and Auckland respectively, and integrated aspects of the 'cult of beauty' into their art and living environments. Based on this research, I argue for a more nuanced understanding of how local and international tendencies interacted within New Zealand's art. 


\section{ACKNOWLEDGEMENTS}

I wish to express my gratitude to supervisors Associate Professor Roger Blackley and Professor Geoffrey Batchen for the opportunity to participate in the Master's programme. I sincerely value your professionalism, guidance, encouragement, and engagement with this research project. To the Victoria University of Wellington Humanities and Social Sciences Research Grant Committee - Thank you for financial support which enabled me to obtain crucial material during visits to various institutions throughout New Zealand and Melbourne, Australia.

I convey my appreciation to the following people and teams who assisted with my research project. I recognise the valuable contribution they make to New Zealand's art history.

- Museum of New Zealand Te Papa Tongarewa. Librarian: Victoria Boyack. Curators of applied arts: Claire Regnault, Justine Olsen, Mark Stocker, and Rebecca Rice.

- Curators and staff at Alexander Turnbull Library.

- Hocken Library, Dunedin: Librarians, Curators and Pictorial Collections team, Sarah Snelling, Anna Blackman, Deborah Gale, Anna Petersen.

- Dunedin Public Art Gallery: Assistant Curator, Lauren Gutsell.

- Toitū Otago Settlers Museum, Dunedin: Emma Knowles.

- Dunedin City Council Archives: Alison Brees.

- Olveston, Dunedin: Sue Roy who guided me on two private tours of Olveston - a magical experience.

- Auckland Art Gallery Toi o Tāmaki: E. H. McCormick Research Library, Tom Irwin, Catherine Hammond and Geoffrey Heath. Pictorial Collections, Mathew Norman and collections team for allowing me to view works 'behind the scenes'.

- Auckland War Memorial Museum Tamaki Paenga Hira: Christina Tuitubou, Philippa Robinson and library team - the viewing of Goldie's scrapbooks.

- Christchurch Art Gallery Te Puna o Waiwhetu: Lara Strongman and Ken Hall. 
- Victoria University of Wellington: J. C. Beaglehole Room Collections.

- Manatū Taonga Ministry for Culture and Heritage: Imelda Bargas.

- The home of Bill Main - a fascinating visit on a sunny Wellington afternoon to view and discuss a unique collection.

- National Archives New Zealand: letters between Sir Frederic Leighton and John Roberts discovered here due to the suggestion of a Hocken Librarian when searching through fading inked copies of New Zealand South Seas Exhibition 1889/90 correspondence in Dunedin.

I also wish to recognise the assistance I have received from overseas ins titutions:

- Leighton House Museum.

- Musée Rodin: Curator, François Blanchetière.

- Gainsborough House, England: Director, Mark Bills.

- National Portrait Gallery, London: Associate Curator, Paul Cox.

- National Gallery of Victoria, Melbourne: Assistant Curator, Rebecca Edwards.

- State Library of Victoria: Special Collections.

- The University of Melbourne: My gratitude to Alison Inglis for outstanding hospitality; your interest and advice for my project was uplifting. To Ben Thomas and Terence Lane, thank you for your interest and enthusiasm for my research project.

Finally, a special thank you to all staff and fellow postgraduates of the Art History Department, Victoria University, Wellington. You have all provided great support, inspiration and friendship. To my family and friends, thank you for your unwavering support during the writing of this thesis. 


\section{INTRODUCTION}

... we hope to ... observe and record what yet remains of their ancient manners and customs, and if there be any trait, whether of the poetical, of the pathetic, or of the emotional, in their lines (which are not without sentiment), herein lies our duty and the true direction for our study ... We have made a place at least for our flower, let exotics be ever so beautiful. ${ }^{1}$

In his inaugural speech as President of the New Zealand Art Students' Association (founded in December 1883), Kennett Watkins shared with his colleagues what he regarded to be 'the true direction for our study'. That direction involved the incorporation of aspects of New Zealand's indigeno us art forms within the colonial artist's own work.

The relations of Māori and Pākehā cultural traditions, and indeed the relations of local and international art more generally, continue to be a pressing issue for artists working in New Zealand. With that issue in mind, this thesis will examine the intersection of local and international impulses that is manifested in New Zealand's response to the Aesthetic Movement. Signs of the influence of this movement can be found around the turn of the twentieth century, when beauty was thought to reside within exotic artefacts, including Māori artefacts. However, a number of other elements of art making in New Zealand during this period will also be investigated. The aim will be to use this historical study to propose the need for a transnational approach to the art history of New Zealand. This term will argue for the simultaneity of both local and international influences in our art, thereby acknowledging the achronological confluence of local and European art trends one is able to detect in provincial cultures such as New Zealand.

When analysing the patriotic fervour in Watkins's speech, it is clear that this artist was seeking the formation of a national art school. According to Watkins, this art

\footnotetext{
1 'Meeting of the New Zealand Art Students' Association', New Zealand Herald [NZH], 24 December $1883,6$.
} 
should comprise scenes and motifs specific to the region and thereby found 'nowhere else but here in New Zealand'. In his mind, elements necessary to New Zealand art were picturesque views of landscape, accurate figure drawings and the representation of indigenous Māori artefacts. ${ }^{2}$ Watkins suggested to his students that the depiction of historical scenes could be realised through the 'faithful portrayal of our scenery and incidents, by directing the attention of artists to the more careful and exact representation of New Zealand landscape and foliage, flowers, Maori carving' ${ }^{3}$ What is most ambitious about this speech is Watkins's call for the incorporation of indigenous designs into New Zealand's art. This idea is both nationalist and informed by a wider global movement, Aestheticism, in which 'exotic' or 'indigenous' objects were seen to be sources of beauty. Instead of looking elsewhere for objects that would instil this sense of beauty in art and life, Watkins admired the simplicity of line in ancient artefacts closer to home, specifically Māori art.

Watkins expressed concern about the relentless flow of indigenous Māori artefacts exiting New Zealand for the collections of European museums in London, Berlin, Vienna, and Paris. This was a significant observation for a Pākehā artist to be communicating in the early 1880s in New Zealand. In response to this flow, Watkins suggested that the 'true direction' of art studies in New Zealand could not lead to the 'resuscitation' of Māori carving, but would aim at least to document these objects as ancient 'relics' once belonging to this locality. Watkins went on to profess: 'We appeal to you, is not our own [Māori art] worthy of a place? Have we a nationality in an art sense, or have we none? As artists or as people of taste, as New Zealanders, have we ever felt for its beauty?' 4 By referring to the harmony of line in Māori objects, he effectively labels Māori carvings as 'art' and places their indigenous makers in the same league as artisans found elsewhere.

As it happened, Watkins was not the only advocate for the establishment of a national art school and for appropriating Māori 'curios' into an artist's own work. Alfred

\footnotetext{
2 Samuel Stuart's The Interior of a Maori Pa in the Olden Time, 1885 (Auckland Art Gallery Toi o Tāmaki) depicts a historical scene. However, records show that no prizes were awarded in the historical category at the New Zealand Art Students' Association of 1885.

${ }^{3}$ New Zealand Art Students' Association of Auckland for the Year 1884, First Annual Report, Auckland: Wilson \& Horton, 1885, 5.

4 'Meeting of the New Zealand Art Students Association', NZH, 24 December 1883, 6.
} 
Sharpe, a pre-eminent watercolourist and member of the Association, made a remarkable statement in response to negative criticisms of the placement of Māori carvings alongside fine art paintings at the New Zealand Art Students' Association exhibition of 1885. Writing in the New Zealand Herald, Sharpe argued as follows:

You remark that the exhibition has to lower itself into a sort of Maori curiosity shop and botanical garden. I would ask what decorations could be more appropriate to take off the bareness of a building never designed for an art gallery than our beautiful palms and ferns. And with regard to the Maori curios; we call them Maori works of art; and they are so in every sense of the word, and as worthy of exhibition as our own, if not more so. ${ }^{5}$

Obviously, both Sharpe and Watkins supported the appropriation of Māori 'art' and believed it should feature prominently in exhibition displays. Their propositions represent a confluence of European and provincial ideas, creating a quite particular context for the progress of New Zealand art at this time. With reference to Watkins's speech, I propose to argue that the influence of Aestheticism on New Zealand art has been insufficiently acknowledged in prevailing literature. In order to properly assess its significance, I will suggest that we need to invent a different form of art history that does not simply relay New Zealand's art as a kind of second-hand provincialism borrowed directly from Europe. Watkins, in pressing for a national art, claims that we have to call on our distinctive indigenous heritage. I will argue that his call is ultimately derived from the Aesthetic Movement.

This international phenomenon has been described by New Zealand art historian, Ann Calhoun, as 'the spell of aestheticism'.6 This so-called 'spell' disseminated from the writings of great English poets such as Algernon Charles Swinburne and his German philosophical counterpart Immanuel Kant, who each desired a return to an age of ideal beauty and purity. These ideas were embraced by predominantly British artists and writers residing in London during the 1860s. James McNeill Whistler, Dante Gabriel Rossetti and George Frederic Watts may not have necessarily agreed on a set vision of 'beauty', nor did they share any striking similarities within their respective styles. However, these artists did collectively believe in a phrase devised

\footnotetext{
5 'The Art Exhibition', NZH, 27 October 1885, 6. Cited: Roger Blackley, 'The Exhibitions of Māori Art in Auckland 1884-1885: Documents of the New Zealand Art Students Association', Antic 3, 1984, 121. ${ }^{6}$ Ann Calhoun, The Arts and Crafts Movement in New Zealand 1870-1940, Auckland: Auckland University Press, 2000, 18.
} 
within Aestheticism: 'Art for Art's Sake'. This term promoted 'an art self-consciously absorbed in itself, aware of the past but created for the present age, and existing only in order to be beautiful' ${ }^{7}$

A member of this 'cult of beauty' would be able to detect the signs of Aestheticism in many different media, recognising it in, for example, the decorative presence of peacock feathers, sunflowers, birds, roses, and lilies. The English writer Oscar Wilde was an avid supporter of an elitist lifestyle that immersed its dedicated followers in an 'other-worldly' realm. This realm was achieved by adherents surrounding themselves with beautiful paintings, designs, drapery, and costumes that decorated the interiors of private residences, artists' studios and public municipal buildings. An interest in the 'exotic' enabled true Aesthetes to place elements of Japonisme within their didactic fantasy. Hence the interest in Japanese and Chinese blue ceramics, as well as in fans, screens, prints, kimonos, and other textiles. ${ }^{8}$ These aspects of Victorian Aestheticism can be found in New Zealand in a range of objects and spaces, including paintings, photographs, the artist's studio, clothing, ceramics, and house interiors during the period of 1880 to 1913.

In existing analyses of New Zealand's art history, the influence of the Aesthetic Movement has generally been overlooked and there has not been sufficient examination of it. Scholars have most commonly referred to the importance of 'Impressionism' in New Zealand art, but have chosen to acknowledge only in passing the influences of the Aesthetic Movement. Jane Vial, for example, has commented that 'no record of studios furnished in the Aesthetic manner has come to light in New Zealand'. ${ }^{9}$ This thesis will seek to contest this claim. It is true that the studios of 'local' artists in New Zealand did not offer an exact 'decorative' arrangement of the type favoured by Victorian Aesthetes such as Edward Burne-Jones, Frederic Leighton or James McNeill Whistler. However, they did create an environment of tactile delight and beauty, with a pronounced interest in the 'exotic' cultures of New Zealand and

\footnotetext{
7 Stephen Calloway and Lynn Federle Orr (eds.), The Cult of Beauty: The Aesthetic Movement 18601900, V\&A Publishing, 2011, 11.

8 Wilde's infamous remark: 'Oh, would that I could live up to my blue china'. Cited: Elizabeth Aslin, The Aesthetic Movement: Prelude to Art Nouveau, London: Elek Publishing, 1969, 98.

9 Jane Davida Vial, 'Painting in New Zealand and Australia 1884-1904'. M. A. Thesis, Art History,

Victoria University of Wellington, 1993, 58.
} 
abroad. The aims of Aestheticism, as discussed by Walter Pater in his book The Renaissance, sought to promote 'the power of being deeply moved by the presence of beautiful objects. He [the artist] will remember always that beauty exists in many forms'. ${ }^{10}$ That dictum was frequently manifested in New Zealand art during the midto-late 1890s and it was sometimes invested in aspects of Māori art.

Although not mentioning the Aesthetic Movement directly, art historian Rebecca Rice found reports in this period suggesting it was common practice to:

consider Māori products as 'art' as opposed to mere 'curiosities', conferring status upon the objects and suggesting they are a valid source for inspiration and appropriation by European artists and designers. ${ }^{11}$

This desire to collect, document and admire the 'decorative' qualities of indigenous artefacts in New Zealand is a distinctive aspect of this country's art history. When observing the situation of our closest neighbouring country, Australia, past and present, the relations that have been forged with the indigenous people are quite different. Artists living and practising in Australia in the late nineteenth century did not desire to recognise, elevate or even acknowledge the designs or culture of Aboriginal people (let alone to define these 'primitive' objects as 'art'). ${ }^{12}$

Art history is a rational discourse where art movements are usually placed in sequence, with one influencing the next in a sort of evolutionary narrative. The problem with this model is that it does not reflect what actually occurred in New Zealand. Provincial histories are often complicated, as art movements invariably arrived in the provinces late and, in some cases, all in one moment. For example, in the 1880s, the ideas connected with Aestheticism and Impressionism may have arrived in some remote localities on literally the same boat. It is therefore not appropriate to simply state that our 'local' arthistory is unoriginal or derivative. The

\footnotetext{
10 Pater, The Renaissance, xii.

11 Rebecca Rice, 'Picturing Progress in Paradise: New Zealand on Display at International Exhibitions 1873-1886', M. A. Thesis, Art History, Victoria University of Wellington, 2003, 119.

12 An Aesthetic-like representation of an indigenous Aboriginal woman is featured in Sydney Long's The Music Lesson of 1904 (Sydney: Art Gallery of New South Wales). However, this is an exception. It was not until the late 1920s that The Jindyworobak Movement looked to the designs of Australian Aboriginals for inspiration in literature and art. Margaret Preston, one of Australia's leading modernists was associated with this movement. See Deborah Edwards, Margaret Preston, Sydney: Art Gallery of New South Wales, 2005.
} 
'wilful borrowings' of artistic traditions from our European counterparts ultimately translated into something original and specific to New Zealand. Art in New Zealand in the mid-to-late nineteenth century should therefore not be interpreted as a kind of slavish second-hand borrowing of Western art history. In reality, here in New Zealand, the Academic, Aesthetic, Impressionist, Symbolist, Arts and Crafts, and Art Nouveau movements are all interconnected and enmeshed. This points to a complex integration of the establishment of avant garde practices in the antipodes. ${ }^{13}$ It is therefore crucial to understand the unique circumstances pertaining to the introduction of avant-gardism in remote localities such as New Zealand.

How, then, has Aestheticism been treated in New Zealand art history before now? Gordon H. Brown's exhibition catalogue New Zealand Painting 1900-1920 outlines the conditions in which early twentieth-century New Zealand art was produced. In order to do so, Brown reflects on the ramifications of what has occurred during this period-the significance of the first international exhibition to be held in New Zealand in 1889-1890, the arrival of immigrant artists and the novel approaches to art that arrived with them. In this book, Brown is the first art historian to acknowledge the presence of Aestheticism in New Zealand. The far-reaching effects of this international movement are discussed as follows:

Although largely drained of its vitality, the Aesthetic Movement still cast its shadow on New Zealand painting in the 1900s. Less well defined than the arts and crafts movement, which in some directions it paralleled and overlapped, the Aesthetic Movement was, however, a good deal more receptive to ideas from the Continent. ${ }^{14}$

Brown's comment on the state of New Zealand painting at the turn of the century supports the notion that, when attempting to formulate an appropriate art history for this country, one cannot simply mirror a 'neat' or sequential narrative derived from European art. Brown argues that, due to our geographical isolation, artistic and intellectual ideas crafted in Europe arrived in New Zealand decades later and in a somewhat 'overlapped' and 'drained' state.

\footnotetext{
13 See Vial, 'Avant-Garde Painting', 1993.

14 Gordon H. Brown, New Zealand Painting 1900-1920: Traditions and Departures, Wellington: Queen

Elizabeth Arts Council of New Zealand, 1972, 23.
} 
This temporal time lag should not hinder the importance of taking into consideration the Aesthetic Movement's arrival in New Zealand. In fact this 20-year time delay affirms the distinct and unique interpretations of Aestheticism and its reception that occurred outside of Britain, France and the United States of America. Artists living and practising in New Zealand were presented with a unique oppor tunity to pick and choose elements of various imported movements they would adapt to local conditions. This thesis will attempt to define the parameters of what we can and cannot include in our assessment of Aestheticism in New Zealand between 1880 and 1913.

Similar patterns of 'overlapping' have been identified in literature published in relation to antipodean art history. Terence Lane's Australians at Home suggests the Aesthetic Movement and Arts and Crafts Movement were 'blended' in the antipodes. Lane suggests the reasons for this 'overlap' are partly due to the delay in its arrival and also the longevity of this popular movement. ${ }^{15}$ In his assessment of 'Australian Aestheticism' in domestic interiors, he argues that it is difficult to define the boundaries between these specific movements. However, Lane endeavours to set parameters and explain this movement's significance in Australia during the last quarter of the nineteenth century. In similar fashion, as part of her $\mathrm{PhD}$ research, Anna Petersen analysed the Aesthetic Movement and domestic spaces in New Zealand. Her study identifies a local adaptation of Aestheticism in relation to the incorporation of Māori design. This point will be factored into my assessment of Aestheticism and the paintings produced at the end of this period.

Gordon H. Brown's work continues to be the foundation on which any such assessment must be built. Within the transition 'between the dying of one century

\footnotetext{
15 In my discussions with Alison Inglis and Terence Lane, two leading art historians of Australian art, they both claim there was a close connection between Australia and New Zealand through trade, which could have formed into a kind of South Seas Aestheticism in the 1880s. This project will primarily be looking at Aestheticism in New Zealand. However, it is valuable to know that Aestheticism is prospering in both countries between 1880 and 1913. Further reading on Australian Aestheticism; see, Terence Lane, Australians at Home: Documentary History of Australian Domestic Interiors from 1788 to 1914, Oxford: Oxford University Press, 1990, 37-40; Alison Inglis, 'Aestheticism and Empire: The Grosvenor Gallery Inter-colonial Exhibition in Melbourne, 1887', Seize the Day: Exhibitions, Australia and the World, edited by Kate Darian-Smith et al, ebook, Melbourne: Monash University, 2008, 16.116.17; Ann Galbally, 'Aestheticism in Australia', in Anthony Bradley and Terry Smith (eds.), Australian Art and Architecture: Essays Presented to Bernard Smith, Melbourne: Oxford University Press, 1980, 124-33.
} 
and the birth of another', Brown considers the enduring legacy of one prominent English writer, John Ruskin. Ruskin is said to have made an emphatic impression on the minds of young artists in England, and even as far away as New Zealand.

According to Brown, Ruskin's strong argument for the assimilation of Aesthetic ideas sought to promote 'the notion of beauty; for art to be beautiful, it had also to be instructive and true in essence to nature'. ${ }^{16}$ An example of this Ruskinian appraisal being openly conferred upon artists practising in New Zealand is included in a series of lectures presented by the director of the School of Art Christchurch in 1906. In a lecture on 'decorative art', Robert Herdman-Smith argued as follows:

As one cannot see colour without light, neither can we expect sensibility to beauty to grow up naturally amid sordid and dull surroundings. To begin with, then, before we can have this impulse and sensibility towards beauty, it is necessary to create an atmosphere of beauty... Seeking beautiful Art. ${ }^{17}$

Evidently, Herdman-Smith, an English painter, sculptor and accomplished musician, shared this desire with his students - to elevate this sense of beauty into all aspects of art and life. One of his pupils was Raymond Francis McIntyre, a Christchurch-born artist and musician, who is said to have been a great admirer of James McNeill Whistler. ${ }^{18}$ Before making his decision to leave New Zealand in search of success at the Royal Academy, London and the potential of being 'hung-on-the-line', McIntyre had been exposed to the latest fashions and art education witnessed by Sydney Lough Thompson. Thompson, who had recently returned to New Zealand from London and Paris in 1905, shared his experiences of art training and bohemian life with his fellow artists in Christchurch, eventually co-founding an informal Sketch Club. It was established for the purpose of allowing like-minded artists to meet and learn how to draw. In Thompson's studio located on Cambridge Terrace, a group of male artists observe the female model wearing a kimono and holding a Japanese fan [Plate 6]. This photograph suggests that McIntyre, standing quite confidently at his easel behind Thompson, was exposed to the latest 'craze' for the beauty of Japan and

\footnotetext{
16 Brown, New Zealand Painting, 23.

17 'Mr R. Herdman-Smith and His Art', Weekly Press, 26 September 1906, 39.

18 Michael Dunn, New Zealand Painting: A Concise History, Auckland: Auckland University Press, 2003, 60 .
} 
emphasis on learning to draw from antique and life. He learnt these invaluable lessons before leaving for London in February 1909.

In Francis Pound's Frames on the Land, the author discusses the arrival of three professional artists between 1890 and 1903. The work of Nairn, Nerli and Friström 'carried as many traces of styles before and after Impressionism as it did qualities of Impressionism itself' ${ }^{19}$ Pound is acknowledging the presence of a range of art movements and ideas being brought to New Zealand in the early 1890s. However it is noticeable in Pound's book that he does not mention the Aesthetic Movement in particular. When referring to the artist James McLauchlan Nairn (1859-1904), Pound makes reference to Nairn's 'Impressionistic' style and the artist's admiration for the founder of Naturalism, Jules Bastien-Lepage (1848-1884). ${ }^{20}$ This view of Nairn's style as being exclusively Impressionist has been present since the writings of the first New Zealand art historian, Eric H. McCormick. ${ }^{21}$ In his 1940 book Letters and Art in New Zealand, McCormick states, 'It was chiefly through Nairn that Impressionism came to New Zealand'.22 This thesis is not refuting these claims. But it will endeavour to take a revisionist 'look' at the degree to which Aestheticism also captivated the minds of professional artists in New Zealand such as Nairn, Nerli and their contemporaries. To view artists such as Nairn and Nerli strictly in terms of their Impressionist credentials does not present the full picture.

Along with Gordon H. Brown and Hamish Keith, Pound was one of the first art historians to critically question the relationship of 'local' artists, living and working in New Zealand, to the Euro-centric standards of French Impressionism. According to Pound, 'The Progress of Art in New Zealand', 'a paper read [by Nairn] to the

\footnotetext{
19 Francis Pound, Frames on the Land: Early Landscape Painting in New Zealand, Auckland: William Collins Publishers Ltd., 1983, 26.

${ }^{20}$ An undated newspaper clipping claimed Nairn had a print of Bastien-Lepage' Pas Mêche in his Wellington studio. Nairn may have obtained this print from a reproduction made in The Scottish Art Review, 1, 4, September 1888, 113. See Vial, 'Avant-Garde Painting', 1993, 26; Nairn, Scrapbook, (Wellington: Te Papa).

${ }^{21}$ E. H. McCormick, Letters and Art in New Zealand, Wellington: Department of Internal Affairs New Zealand, 1940, 120; Harry H. Tombs (ed.), A Century of Art in Otago, Wellington: Harry H. Tombs Ltd, 1947, 19; Hamish Keith, 'James McLauchlan Nairn 1859-1904', Auckland City Art Gallery Quarterly, 25, 1963, 5; Gil Docking, Two Hundred Years of New Zealand Painting, Wellington, 1971, 78; Michael Dunn, 'Notes on Nairn in Glasgow', Bulletin of New Zealand Art History, 5, 1977, 12; Vicky Hearnshaw, 'James McLauchlan Nairn: The Glasgow Years', unpublished, October 1990, 18-19; Roger Blackley, 'First Impressionists', Listener, 17 July 2010, 44.

22 McCormick, Letters and Art in New Zealand, 120.
} 
Wellington Art Club in 1892, is the most important document we have of his ideas' ${ }^{23}$ A transcript of this lecture, published in a New Zealand newspaper, reveals Nairn's interest in the importance of light and painting outdoors. These views are predominantly associated with the doctrine of Impressionist painting; that is, to paint the immediacy of nature through the study of light and colour.

However, neither McCormick nor Pound refers to the content of Nairn's first lecture in New Zealand, presented only six months after his arrival in Dunedin in 1890. Michael Dunn, in a booklet published by the National Art Gallery, claimed that the text for this lecture was lost. ${ }^{24}$ Victoria Hearnshaw includes 'Decorative Art' in the bibliography of her 1992 Master's thesis, 'James McLauchlan Nairn: The New Zealand Years', but at no point is the content of the lecture sufficiently analysed. ${ }^{25}$ I will argue that Nairn's 'Decorative Art' lecture of 1890 is a valuable record of this artist's ideas and is a vital starting point in our attempt to understand the influences of Aestheticism in New Zealand art.

My thesis comprises three chapters that investigate the presence of Aestheticism in the art and surroundings of artists, such as Nairn, Nerli and Goldie. Although these artists did not collaborate and may not be grouped together stylistically, I will argue that they all shared an appreciation for aspects of Aestheticism. This is evident when examining each artist's studio, private correspondence, and most importantly, the artworks they produced between 1880 and 1913.

Chapter One will define the parameters of what we may consider to be a part of this term 'Aestheticism'. This discussion encompasses the European perception of the Aesthetic Movement, a term devised in England during the 1860s. It will then determine its effects on the writers and artists of New Zealand, who interpreted this 'cult of beauty' through a colonial lens. Chapter Two will take a deeper look at Nairn's 'Decorative Art' lecture of 1890 and the notion of surrounding artists and the 'ordinary public' with beautiful objects. The idea of beauty in art and life will be

\footnotetext{
23 Pound, Frames on the Land, 84.

${ }^{24}$ National Art Gallery, Nairn and his Associates, Supplement, Wellington: Madison Print Ltd., 1975, unpaginated; George E. S. Packwood, Nairn and his Associates. Selected from Works in the Collection of the National Art Gallery, 4, Wellington: National Art Gallery, 1969, unpaginated.

25 Victoria Hearnshaw, 'James McLauchlan Nairn: The New Zealand Years', M. A., Art History,

Christchurch: University of Canterbury, 1992, 160.
} 
developed further in Chapter Three where I will examine the opulent studio environment of Charles F. Goldie at the turn of the century. The manner in which Goldie decorates his studio reflects the artist's desire to encapsulate the beauty of Parisian studios in New Zealand with his collection of Māori, European and Japanese art objects. My Conclusion will draw all these threads together, proposing that Nairn and Goldie transcend the oppositional status that has been applied to these artists in previous literature - the avant garde versus the academic tradition. Through an Aesthetic lens it is apparent that both Nairn and Goldie inhabited similar social realms and produced art that are more closely aligned than art historians have previously acknowledged in New Zealand art. 


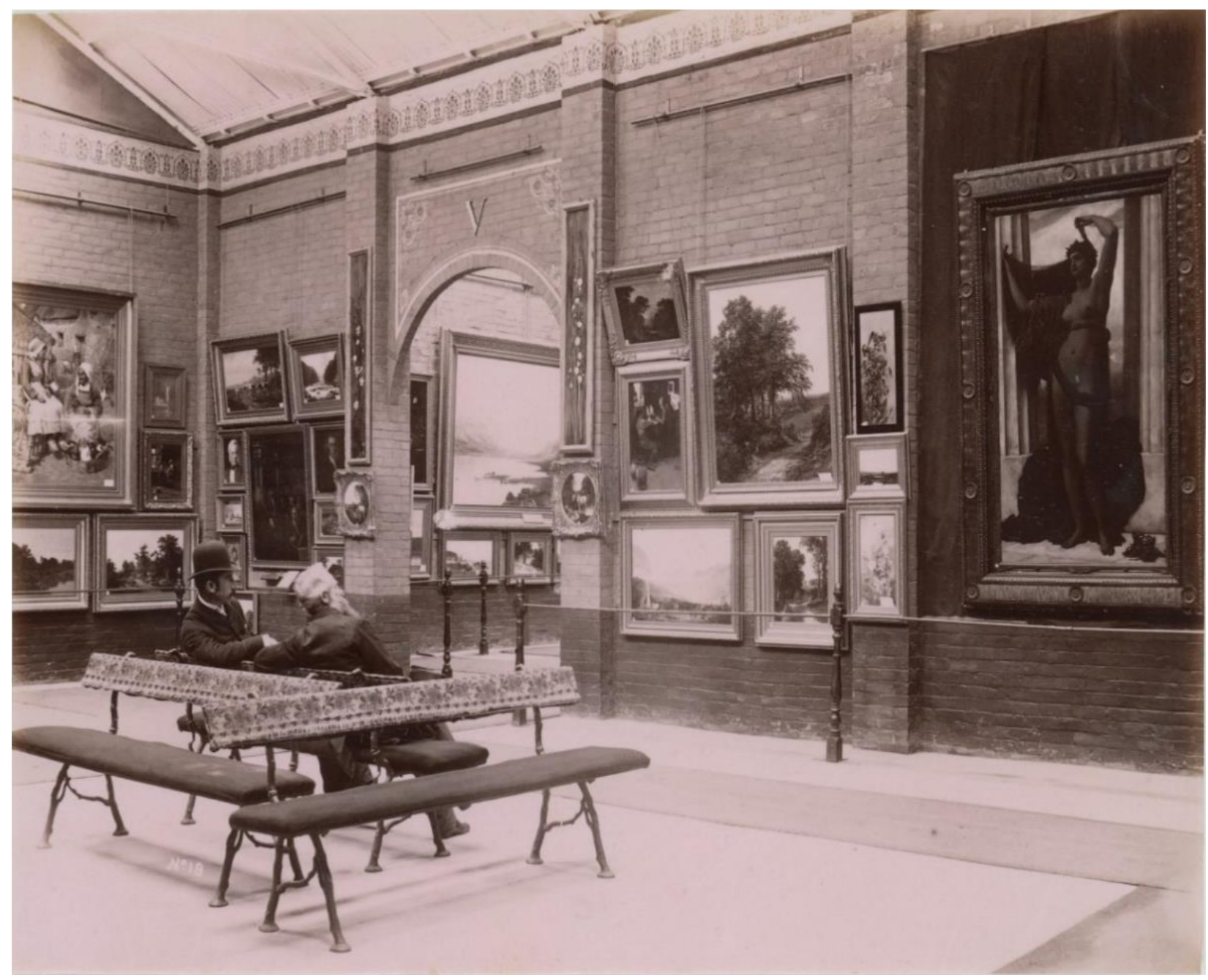

Plate 1: G. P. Nerli (on left) and David Con Hutton (on right) sitting in front of Leighton's Phryne hanging in pride of place at the New Zealand and South Seas Exhibition, 1889-90. (Alexander de Maus Album, Dunedin: Toitū Otago Settlers Museum, Ref. 1919.134.324). 


\section{Chapter One}

\section{THE ORIGINS OF AESTHETICISM: AN INTERNATIONAL MOVEMENT}

The Aesthetic Movement, as it came to be known, was an international phenomenon that cultivated the idea of beauty in art and life. ${ }^{1}$ In response to an age of consumer capitalism and advances in manufacturing and technology, Aestheticism provided an opportunity for artists and poets to revitalise society through art and literature. 'L'art pour l'art' or 'Art for Art's Sake', a term coined by French writer Théophile Gautier in his novel Mademoiselle de Maupin of 1835, encapsulated the desires of artists and poets in the later nineteenth century, including those living in Australia and New Zealand. 'Art for Art's Sake' offered a new way of seeing - an aesthetic and intellectual innovation that instilled beauty in art objects, the home, the artist's studio, and public buildings.

The ideologies of the Aesthetic Movement were admired, not only for the artistic and intellectual stimulus that they provided to individuals who surrounded themselves with beautiful objects, but also as a philosophy and even a kind of theology. With uncertainties surrounding religious devotion and increasing support for secularisation in Victorian England (and in her colonies), Aestheticism, the so-called 'poisonous honey stol'n from France' started to grow in popularity amongst the social elite. ${ }^{2}$ One avid proponent, who supported the nurturing of Aesthetic ideals and wished for them to be viewed as 'the religion of art', was Walter Pater. The English

\footnotetext{
${ }^{1}$ An alternative term for the 'Aesthetic Movement' is 'Aestheticism'. I will only use the term 'movement' when referring to the Aesthetic Movement in England and the United States of America. In this thesis, preference will be given to the term Aestheticism when referring to its presence in New Zealand, as I believe it is inappropriate to define it as a 'collective' movement, when it is more of a dissemination of ideas. For further discussion of this approach, see, Stephen Calloway and Lynn Federle Orr, The Cult of Beauty: The Aesthetic Movement 1860-1900, V\&A Publishing, 2011, 13; Lee Glazer and Linda Merrill (eds.), Palaces of Art: Whistler and the Art Worlds of Aestheticism, Washington D. C.: Smithsonian Institution Scholarly Press, 2013, 7. 2 Janice Nadelhaft, 'Punch and the Syncretics: An Early Victorian Prologue to the Aesthetic Movement', Studies in English Literature 1500-1900, 15, 4, 1975, 628.
} 
writer Richard Le Gallienne often proclaimed that Pater 'was virtually the founder of the Aesthetic Movement'. ${ }^{3}$

In his preface to The Renaissance: Studies in Art and Poetry (1873), Pater denotes the 'true' aims of the Aesthete:

To define beauty, not in the most abstract, but in the most concrete te rms possible, to find, not universal formula[e] for it, but the formula which expresses most adequately this or that special manifestation of it, is the aim of the true students of aesthetics. ${ }^{4}$

This modern artistic philosophy bestowed a sense of independence on the student of art. In turn, Aestheticism granted a sense of autonomy for the artist and their chosen practice. The ambiguity about what style or subject to follow in this pursuit led to one of the first truly modern art movements that allowed artists to focus on creating an art object that was appreciated for its aesthetic qualities alone. Given the vagueness of Pater's definition, artists interpreted the notion of 'Art for Art's Sake' in different ways and created a range of styles. In general, Aestheticism in Victorian painting consisted of 'decorative' works across many genres, including landscape, portraiture, Neo-Renaissance mural paintings, illustrations, and applied art. For many art historians this fragmentary choice of genre and medium has made it difficult to determine which artists should fall within the parameters of Aestheticism. What these artists do have in common is an endeavour to adopt this 'modern' artistic philosophy, stemming from Kantian ethics and idealism, to make works that celebrate art itself. With the rise of secularism in England, the philosophical and spiritual essence of Aestheticism became a religious metamorphosis requiring its followers to dedicate one's life to art and completely adapt one's lifestyle to 'worship' beauty. 5

The Aesthete, whether an artist or writer, shared a common trait when creating art or literature. This is demonstrated in Sidney Colvin's understanding of Aestheticism in the late 1860s. He believed an Aesthete created 'the art whose aim is beauty' ${ }^{6}$ The

\footnotetext{
3 Richard Le Gallienne, The Romantic '90s, London: Putnam, 1926, 74.

4 Walter Pater, The Renaissance, Studies in Art and Poetry, London: Macmillan and Co. Ltd., 1900 (originally published in 1873), ix.

5 Glazer and Merrill (eds.) Palaces of Art, 107.

${ }^{6}$ Sidney Colvin, 'English Painters and Painting in 1867', Fortnightly Review, 1 October 1867, 472.
} 
sharing of this aim has allowed art historians in the present to write comprehensive monographs which group artists who worked predominantly in Britain and to declare them proponents of the idea of creating beauty in art and life. ${ }^{7}$ Art historian Elizabeth Aslin, for example, has shared her understandings of those figures that should be included in this group. In her book The Aesthetic Movement: Prelude to Art Nouveau, she suggested that 'the essence of the movement is the union of persons of cultivated tastes to define and decide upon what is to be admired.' ${ }^{8}$ According to this definition, the artists commonly associated with Victorian Aestheticism are James McNeill Whistler, George Frederic Watts, Albert Moore, Edward Burne-Jones, Dante Gabriel Rossetti, Lawrence Alma-Tadema, Walter Crane, William Morris, and Frederic Leighton.

Although many of these artists differed in their approaches and degrees of loyalty to the cause of Aestheticism, they all sought to induce a kind of nostalgia for an idyllic past that may not have necessarily occurred in the first place. Artists wished to create this other-worldly experience to escape their present moment. This desire to return to a romantic past time resulted in a juxtaposition of both local and foreign impulses. Those who were part of the Aesthetic Movement in England can be identified with the revival of art from the Renaissance and Georgian periods. The incorporation of elements from these periods resulted in quite a Gothic dimension to the works. They are also credited with taking inspiration from the Neo-Classical austerity presented in Joshua Reynolds's portraiture or frescoes created by the Early Renaissance painter Giotto, which spurred these English Aesthetes to study from life and the antique. The figures in Giotto's frescoes were static and expressed very little emotion; two characteristics that were borrowed from the past and integrated into 'Aesthetic' painting.

\footnotetext{
${ }^{7}$ Refer to Elizabeth Prettejohn, Art for Art's Sake: Aestheticism in Victorian Painting, New Haven and London: Yale University Press, 2007; Charlotte Gere, Artistic Circles: Design \& Decoration in the Aesthetic Movement, London: V\&A Publishing, 2010; Christopher Newell, The Grosvenor Gallery Exhibitions: Change and Continuity in the Victorian Art World, Cambridge University Press, 1995; Calloway and Federle Orr, The Cult of Beauty.

8 Aslin, The Aesthetic Movement, 14.
} 
Emerging artists in the late 1870s were regarded as 'second-generation PreRaphaelites', and they inherited a 'trained eye' for depicting medieval subjects. ${ }^{9}$ Susan Casteras argued that the Victorian era saw the overlap of Pre-Raphaelitism and the Aesthetic Movement. ${ }^{10}$ This is demonstrated in Edward Burne-Jones's scenes of Arthurian legend and female figures in a contemplative state of melancholic languor, which featured prominently at the Grosvenor Gallery. Hung alongside the firstgeneration Pre-Raphaelites' paintings may have been works by the so-called 'Victorian Olympian' painters, such as Frederic Leighton, Albert Moore and George Frederic Watts. These English painters admired the eighteenth-century Georgian period for its restoration of Classical ideas, the study of antiquity and the restraint of its art and architecture. The gallery also contained works by Walter Crane, who endeavoured to include both Gothic and Classical features in his paintings. All of these artists surveyed past ages for inspiration. The blending of past and present influences provides a plausible explanation why writers such as Oscar Wilde and Walter Hamilton frequently refer to the terms 'Classical' and 'Mediaeval' in their definitions of Aestheticism.

An iconic sign of the Aesthetic Movement was an increasing interest in art of the 'ancient world'; that is, Greek, Persian, Indian, Chinese, and Japanese art, pertaining especially to their fashions and artefacts. Since the first trade agreement was signed between Great Britain and Japan in 1859, Victorian Aesthetes shared a certain fascination with decorative oriental ornaments and designs - whether they were authentic or Anglo-Japanese reproductions. The importation of authentic relics from Asia (prints, porcelain, screens, fans, and manuscripts) assumed a cult-like status in Victorian England. These foreign objects provided an opportunity for members of the elite classes to momentarily escape the morbid reality of industrial Britain. They could do so by entering public buildings or private residences that were lavishly decorated in an oriental style - a type of oasis that could transport the artist, writer or wealthy patron to an exotic elsewhere.

\footnotetext{
9 The Pre-Raphaelite Brotherhood was an English art movement founded in 1848. Edward BurneJones exhibited at the Grosvenor Gallery, London. His compatriot Daniel Gabriel Rossetti, on the other hand, chose not to hang his art in 'the Palace of the Aesthetes'. 10 Susan Casteras and Colleen Denney (eds.), The Grosvenor Gallery: A Palace of Art in Victorian England, New Haven and London: Yale University Press, 5.
} 
Over time, a more complete definition of the 'Aesth etic' began to evolve. By 1882, Walter Hamilton relayed his general observations around the complexities associated with defining this term:

Botticelli and E. Burne-Jones, Oxford and Japan, Romeo and Juliet at the Lyceum Theatre and Patience at the Savoy, Wagner and Sullivan, Swinburne and Oscar Wilde; how widely asunder do these all sound, how dissimilar their attributes, yet each and all in a manner aggregate to form the Aesthetic school, and have helped it to the position it holds at present, high in the estimation of all true lovers of the ideal, the passionate, and the beautiful. ${ }^{11}$

Notably, this excerpt demonstrates that Aestheticism could encompass a range of artistic disciplines under one common ideological thread. Despite the apparent difference in art practices such as painting, 'decorative' arts and even theatre, each Aesthetic creative mind shared a dedication to surrounding themselves and the general public with all things beautiful. ${ }^{12}$ Their mission from the outset was to elevate the minds, souls and bodies of Englishmen, in a desire to attain 'not pleasure, but a general completeness of life'. ${ }^{13}$

These aims were reflected in the opening of the Grosvenor Gallery in $1877 .{ }^{14}$ This socalled 'Palace of Art' enabled its patron, Sir Coutts Lindsay, and selected contemporary artists (predominantly Aesthetes) to compose a social arena of Aesthetic delight that was designed to enhance modern sensibilities and taste in Victorian England. ${ }^{15}$ Oscar Wilde, a proponent of Aestheticism, was said to have visited the gallery in its opening year dressed in brightly coloured suits adorned with a lily or sunflower (these were later identified as noticeable symbols of a 'true' Aesthete). ${ }^{16}$ Walter Pater found it difficult to explain how the sunflower, lily and the peacock feather had become so closely identified with the movement, especially

\footnotetext{
11 Walter Hamilton, The Aesthetic Movement in England, New York and London: Garland Publishing, 1986 (first published in 1882), 124.

12 This inclusive attitude and equal treatment of art disciplines (not just painting) led to the emergence of the Arts and Crafts Movement. An avid proponent of this movement was Walter Crane, who is identified as a key figure in both the Aesthetic Movement and the Arts and Crafts Movement in England during the 1880s and 1890s.

13 Elsie B. Adams, Bernard Shaw and the Aesthetes, Columbus: Ohio State University Press, 1971, 37.

14 The Grosvenor Gallery will abbreviated to the 'Grosvenor'.

15 Alfred Tennyson, 'The Palace of Art', Poetical Works, London: Macmillan \& Co., 1916, 44-49.

16 See description of Wilde in 'London's Aesthetic Young Man', Evening Star [ES], 19 August 1881, 4; 'Aestheticism in London', Nelson Evening Mail [NEM], 17 October 1881, 4; 'An Aesthetic Ball', New Zealand Tablet, 7 October 1881, 5.
} 
considering the superstitious folklore suggesting peacock feathers to be unlucky. ${ }^{17}$ These emblems of Aestheticism were nevertheless, a distinctive and meaningful insignia for the wearer or owner; a peacock feather or a sunflower signified loyalty to the cult of Aestheticism. This individual was typically of high intelligence, wealth, status, and also a worshipper of a type of theology or belief system devoted to exquisite beauty in all aspects of life.

Wilde commented on his reaction to the overall feeling of the Grosvenor space:

As far as the Gallery itself is concerned, there are only three rooms, so there is no fear of our getting that terrible weariness of mind and eye which comes on after the 'Forced Marches' through ordinary picture galleries. The walls are hung with scarlet damask above a dado of dull green and gold; there are luxurious velvet couches, beautiful flowers and plants, tables of gilded and inlaid marbles, covered with Japanese china and the latest 'Minton', globes of 'rainbow glass' like large soap-bubbles, and, in fine, everything in decoration that is lovely to look on, and in harmony with the surrounding works of art. ${ }^{18}$

The ostentatious 'greenery-yallery' environment of the Grosvenor Gallery was mocked four years later in Gilbert and Sullivan's comic opera Patience (1881). In the 1880s, feelings towards the Aesthete oscillated between tolerance of the harmless ineffectual outcast and condemnation of something more sinister. Both stereotypes were seeking to denigrate the individual's status in society and challenge their belief system. Despite brooding 'anti-Aesthetic' fervour in Gilbert and Sullivan's satire and George Du Maurier's cartoons in Punch, there was a surge of interest for the aims of Aestheticism by artists, writers and elite members of the general public. Craving the decadence of an Aesthetic lifestyle, many followers were attracted to the exaggerated portrayal of an Aesthete in Patience. Oscar Wilde, the so-called 'High Priest' of Aestheticism, elaborates on the public's reception of the satirical operetta:

Patience, by the way, has done our cause no harm. Ridicule may be a serious weapon, but there should be that in a true poet or a genuine cause which is indestructible; and there is indestructibility in our cause. Oh no, people understand that Patience is merely a burlesque. I enjoyed it very much. The

\footnotetext{
17 Hamilton, The Aesthetic Movement in England, 35.

18 Oscar Wilde, 'The Grosvenor Gallery', Dublin University Magazine, July 1877, 118-126. Cited: Newall, The Grosvenor Gallery Exhibitions, 15.
} 
music is delightful, and that is certainly on our side, even if the words are not. 19

Many proponents of Aestheticism, including Wilde, believed this satire enhanced the reputation of the movement and created a newfound awareness of Lindsay's Grosvenor Gallery in London. The Grosvenor soon became a social arena for the wealthy and privileged to discuss the elevation of beauty in art-a place for seeing and, more importantly, for being seen.

In 1882, the journalist Walter Hamilton's popular account The Aesthetic Movement in England commented on the politics involved with the establishment of the Grosvenor:

... in the Grosvenor Gallery the more exclusive system has been adopted of inviting artists to exhibit. This method of admission has enabled painters who were either unwilling (as many were) or unable to obtain entrée into the Royal Academy, to bring their best works prominently before the general public, without having to run the gauntlet of jealousy of the Royal Academicians, and without having to bow down before a narrow-minded and exclusive clique, which settles not only who shall exhibit, but can at any time punish an unpopular man by placing his work so high, or so low, that only a giant or child can catch a glimpse of it. ${ }^{20}$

Hamilton's comments provide an insight into the public's growing dismay with the 'collective egoism' overshadowing the once prestigious Royal Academy. Officials were criticised for the poor treatment of students and failure to exhibit their works. This negativity towards the teaching methods of the Academy is voiced in the Magazine of Art, where a critic writes:

As an educational institution its influence is practically non-existent: it [the Royal Academy] has little or nothing to teach; and its students, as soon as they have passed the curriculum it imposes on them, make haste to betake themselves to France, to learn, not only how to paint and draw, but to forget as much as they can of the practice and theory acquired in its schools. In Paris they are taught to see and to represent; no painter warns them back from the unholy and unnecessary study of the nude. ${ }^{21}$

\footnotetext{
19 Social columns, criticisms and speeches delivered by Wilde in Britain and the United States were subsequently published in New Zealand periodicals. See 'Sketcher: The Aesthete on his Travels', Waikato Times [WT], 22 July 1882, 6.

20 Hamilton, The Aesthetic Movement in England, 23.

21 'Current Art', Magazine of Art, 8, 1885, 470.
} 
Lindsay's independent gallery, located in New Bond Street, London, provided an alternative space that supported artists with a particular artistic vision. However Christopher Newell does not believe that Lindsay had ever intended the Grosvenor Gallery to be viewed as the salon des refusés of the London art scene. ${ }^{22}$ Artists (both academicians and non-academicians) who were refused entry into the Royal Academy exhibitions of that year were not automatically accepted to exhibit at the Grosvenor. Instead, those favoured by Coutts Lindsay, his wife Blanche and the artist Charles Hallé were invited to show 'decorative' works that were either on loan from a private collection or were available to be sold.

In contrast to the over-crowded arrangement of paintings in the Royal Academy, Lindsay carefully designed his gallery space to avoid this sense of disorder. He ensured that the paintings were hung near eye level and equally spaced. Each painting was hung strategically to please the eye of the viewer and satisfy the heart and mind of its creator. This novel way of displaying works of art demonstrated a modern sensibility that is now accepted as common practice and is standard in twentieth and twenty-first century curatorial practice.

The Grosvenor was a social, commercial and cultural setting. It answered a newfound desire for middle- and upper-class patrons to emulate this sensorial and luxurious Aesthetic environment by acquiring such 'decorative' art objects for themselves. Lindsay's grand scheme and artistic foresight enabled his guests to also envision a sense of harmony in art and nature within their own home, a sense of 'pleasure rather than virtue'. ${ }^{23}$ Thus, the ideals associated with the Aesthetic Movement were not confined to the grand atmosphere of the Grosvenor Gallery but were also increasingly found in the interiors of domestic residences and public buildings in Victorian England. In fact, writers such as Wilde and Crane encouraged the idea that 'beauty' should surround people in all facets of daily life so that they would become fully immersed in the 'House Beautiful.' ${ }^{24}$ John Ruskin, a strong supporter of the 'first generation' of Pre-Raphaelites, shared his beliefs on the

\footnotetext{
22 Newell, The Grosvenor Gallery Exhibitions, 13-14.

23 Deborah Cohen, Household Gods: The British and their Possessions, New Haven \& London, 2006, 79.

24 For more on the term 'House Beautiful'; see, Charlotte Gere and Lesley Hoskins, The House Beautiful: Oscar Wilde and the Aesthetic Interior, London: Lund Humphries, 2000.
} 
importance of integrating the 'second wave' of beauty (or the 'Aesthetic' philosophy) into the domesticity of the Victorian household.

This is the true nature of home-it is the place of Peace; the shelter, not only from all injury, butfrom all terror, doubt, and division. In so far as it is not this, it is not home; so far as the anxieties of the outer life penetrate into it, and the inconsistently-minded, unknown, unloved, or hostile society of the outer world is allowed by either husband or wife to cross the threshold, it ceases to be home; it is then only a part of that outer world which you have roofed over, and lighted fire in. But so far as it is a sacred place, a vestal temple, a temple of the hearth watched over by Household Gods, so far as it is this, and roof and fire are types only of a nobler shade and light - shade as of the rock in a weary land, and light as of the Pharos in the stormy sea - so far it vindicates the name, and fulfils the praise, of Home. ${ }^{25}$

It was the role of these artists to promote new ideologies by integrating the Aesthetic principles of beauty in artand life within the private residences and public building $\mathrm{s}$ of their patrons.

It is important to note that, at this time, Wilde had departed Europe to spread the Aesthetic gospel in the United States. In an interview conducted with Oscar Wilde during the period he was teaching the Aesthetic doctrine in the United States, he shared his own definition of the movement:

The philosophy of Aestheticism is that the secret of enjoyment in life is to be able to understand and appreciate the beautiful. People cross continents to see a lake or a mountain or a waterfall, while the simple creatures who live about these scenes are able to discern earth and water. ... Even today the masses of the people, owing to their grovelling and unbeautiful surroundings, are not able to appreciate the poets. I would like to see everyone able to appreciate the artistic quality of the simplest things around them, and thus, learn of higher things than money getting. My greatest object in visiting this country [America] is to see what effect these ideas will have upon an unprejudiced people, who are not wedded to old conventionalism. I would have Americans make for themselves the beautiful objects they bring from the older world. ${ }^{26}$

This article provided an insight into the aspirations Wilde held for the movement; he believed the Aesthetic Movement would flourish in a 'new world' environment. At this moment, the social conditions of the United States were not too dissimilar to New

25 John Ruskin, 'Sesame and Lilies', Works, 18, 122. Cited: Walter E. Houghton's The Victorian Frame of Mind 1830-1870, New Haven: Yale University Press, 1957, 343.

26 'Sketcher: The Aesthete on his Travels', WT, 22 July 1882, 6. 
Zealand. These two countries were considered independent nations forging in new directions, even though New Zealand retained an appreciable degree of interdependency with Britain. The United States and New Zealand shared similarities as 'new world' territories with the creation of capitalist wealth from an abundance of natural minerals, establishment of government structures and applied efforts to affirm their own cultural identity. The echoing stages of progress in New Zealand and the United States, at this time, are in fact quite important to recognise, as the transcript of Oscar Wilde's thoughts on Aestheticism prospering in new world territories was coincidentally published in a New Zealand newspaper in $1882 .{ }^{27}$

What was once considered a strictly national artistic phenomenon, with links to the English Pre-Raphaelite Movement, had dispersed to new territories. As Lee Glazer suggested in her recent global study of Aestheticism, it would be constructive 'to approach Aestheticism as an art that reaches out, rather than one that turns inward'-allowing it to become a truly international phenomenon. ${ }^{28}$

\section{THE DISPERSAL OF AESTHETIC IDEOLOGIES TO THE SOUTH SEAS}

I am ashamed of young New Zealand. They want a purifying influence-a mad wave of Pre-Raphaelitism, of super Aestheticism should intoxicate the country. Katherine Mansfield, April/May 1908.29

Aestheticism was one of the first international avant garde movements to reach the out-lying colonies of the South Pacific. The signs of this movement first appear in publications that were distributed from England to the antipodes in the early $1880 \mathrm{~s}$. In fact, when considering the importance of literature in relation to the spread of Aesthetic principles, it is not surprising that periodicals enabled these ideas to reach New Zealand. It is therefore inappropriate to simply credit émigré artists, arriving in New Zealand circa 1889, as the first to introduce Aesthetic ideologies to this country. The term Aestheticism had already been mentioned on numerous occasions in art

\footnotetext{
27 Ibid.

28 Glazer and Merrill (eds.), Palaces of Art, 154.

${ }^{29}$ Letter from Katherine Mansfield to Vera Beauchamp in 1908. Cited: David Eggleton, Towards Aotearoa: A Short History of Twentieth-Century New Zealand Art, Auckland: Reed Publishing Ltd, 2007, 11; P. J. Gibbons, 'The Climate of Opinion', The Oxford History of New Zealand, Geoffrey Rice (ed.), 2 ed., Auckland: Oxford University Press, 1992, 318.
} 
journals, newspapers and magazines, forging links between Britain and the colonies. For example, in 1881 an article published in the Nelson Evening Mail discusses 'ultraAestheticism' in London society:

As 'Aestheticism' is the latest London rage, the following graphic account of the Grosvenor gallery and its celebrities will be read with in terest, even at the antipodes: 'This great event was the private view at the Grosvenor. The Grosvenor represents the ultra-Aestheticism, the gilded rose and refined lilyism of that sublimated artistic circle whose members prostrate themselves before Ineffable as manifest in cracked teapots, who speak Chaucerian English, and whose prophets are Burne-Jones and the Rossettis'. The disciples of this ultra-Aestheticism are distinguished from the world's people by affected quaintness or picturesqueness of dress; the women running to dishevelled locks, scant, lank draperies, and a mediaeval melancholy of countenance. ${ }^{30}$

This article suggests that key aspects of Aestheticism and a selection of practising Aesthetes in London were known about long before the British loan paintings were displayed at the New Zealand and South Seas Exhibition in 1889. The notable fashions and customs which were indicative of the Aesthetic Movement had already reached the antipodes through the influx of material from British periodicals.

Members of this international movement considered themselves to be the intellectual elite of society. As Hamilton once professed, Aesthetes are supposed to belong to the 'Upper Crust'. One of the characteristics of the lower middle classes, according to Hamilton, is an intense desire to know, or profess to know, all that goes on in aristocratic circles. ${ }^{31}$ Possessing the knowledge of this movement would be a sign of elevated status in the class hierarchy. Those familiar with the 'cult of beauty', whether upper or middle class, read about the 'Aesthetic man', 'decorative' paintings or latest fashions in London, in the highly ornate pages of the Magazine of Art, Punch or The Studio. These articles were often re-printed in New Zealand newspapers. In 1881, there were 32 articles published in New Zealand periodicals describing 'London's Aesthetic young man', Oscar Wilde. ${ }^{32}$ For the benefit of the colonial reader a description of Wilde's appearance featured in The New Zealand Herald:

\footnotetext{
30 'Aestheticism in London', NEM, 17 October 1881, 4.

${ }^{31}$ Hamilton, The Aesthetic Movement in England, 93.

32 'London's Aesthetic Young Man', ES, 19 August 1881, 4.
} 
The aesthetic poet is patronisingly spoken of, by those who think too much fuss is being made about him, as a harmless young man with a proclivity to velvet suits low in the neck, artistically disordered hair, and an air of mediaeval languor. 33

Wilde's effeminate persona, distinctive dress and decadent lifestyle were often criticised in Punch and Harper's. These fashionable magazines, published in London and New York, mocked the flamboyant lifestyles of the 'apostles' of Aestheticism with unflattering caricatures and witty narratives. British periodicals containing both favourable and derogatory views on Aestheticism circulated widely and were distributed to the colonies.

Publicity surrounding the elitist nature of the Aesthetic Movement inspired the premise for F. C. Burnand's The Colonel and Gilbert and Sullivan's comic operetta, Patience. The two satirical operas, both opening in February 1881, in London, ridiculed the 'apostles' of an Aesthetic lifestyle such as Wilde, Algernon Charles Swinburne, Dante Gabriel Rossetti, Ellen Terry, and James McNeill Whistler. Patience, the 'entirely new and original Aesthetic opera' first caught the attention of New Zealand readers on 4 June 1881, when a female correspondent in London recalled listening to Gilbert describe Patience at a dinner party. ${ }^{34}$ The following week a lengthy description of Gilbert and Sullivan's comic operetta was published in several New Zealand newspapers, preparing local audiences for the impending arrival of the plays through touring theatre companies. ${ }^{35}$

It was only one year after their London premieres that the maiden performances of The Colonel and Patience opened in Australia and New Zealand. The first 'Aesthetic' play to be performed on New Zealand shores was The Colonel on 2 February 1882 at the Princess Theatre, Dunedin. A description of this performance notes the prominent placement of cracked china, lilies and sunflowers on the stage. ${ }^{36}$ In a review of the more popular opera Patience, a critic noted that audiences in Australia and New Zealand were already familiar with these iconic signs of Aestheticism, for

\footnotetext{
33 'Current Gossip', NZH, 24 September 1881, 3.

34 'The Obserber' [sic], Observer, 4 June 1881, 408.

35 'Patience', NZH, 11 June 1881, 7.

36 'The Colonel', ES, 2 February 1882, 2.
} 
example, the symbolic nature of the sunflower appearing in the satirical cartoons produced by George du Maurier in Punch. ${ }^{37}$

In Ann Galbally's assessment of 'Australian Aestheticism', she notes that, following the first performance of The Colonel in Melbourne, satirical caricatures were published as the frontispiece of the Australasian Sketcher, dated 22 April 1882. ${ }^{38}$ The sketches depict both characters of the play and audience responding to this social occasion. A long-haired male figure is illustrated wearing a monocle and holding a sunflower. The figure is a hybrid embodiment of two true Aesthetes, Whistler and Wilde. These comical sketches provide an insight into the mixed reactions of intrigue and suspicion surrounding the Aesthetic 'craze' direct from London.

The J. C. Williamson Theatre Company toured Gilbert and Sullivan's operas around the South Pacific. Stage sets and original cast members of Patience were transported directly from the Theatre Royal, Sydney, to the Princess Theatre, Dunedin. The set reportedly displayed hand-painted scenes of Bunthorne's castle enveloped in lilies, hollyhocks, sunflowers, and decorated with Japanese blue porcelain. Actors were styled as though they were other-worldly. Maidens in Patience were said to possess classical and medieval traits: with flowing Aesthetic dress and very little facial expression. ${ }^{39}$ Their moods were described as melancholic and contemplative, as though they were longing for a distant past time. ${ }^{40}$ An article published one week before the New Zealand premiere of Patience, on 27 February 1882, described the favourable reception of the touring production in England, the United States and, more recently, in Sydney, Australia.

Although modern Aestheticism, as regards Australians, has few, if any, pronounced disciples, and is to the masses an unknown thing, it is undoubtedly true that the newspapers have educated us to a certain familiarity with the practices of the extreme Aesthetic school; and even as London Punch is the most trustworthy fashion journal and the surest index of prominent political questions, so in the continuous discourses and illustrations of Postlethwaite and Maudle we get a picture, exaggerated

\footnotetext{
37 'Patience', NZH, 11 June 1881, 7.

38 Galbally, 'Aestheticism in Australia', 127.

${ }^{39}$ A description of Aesthetic dresses worn by the three maidens are documented in 'Society', Observer, 27 May 1882, 164.

40 The Williamson Opera Company arrived at port in Bluff from Sydney aboard The Rotomahana on 20 February 1882. The cast, including Mr and Mrs Riccardi, were en route to Dunedin for the first performance of Gilbert and Sullivan's Patience. See 'The Critic', Observer, 25 February 1882, 372.
} 
indeed, of that art movement which, within the last few years, has done so much to develop a love of the beautiful among English people. But though the true movement belongs to enthusiastic students, and is presided over by great artists and accomplished scholars, the pretenders are legion, and it is the excesses of the sham Aesthetes which have furnished the materials for Mr Gilbert's charming satire in the Aesthetic opera. ${ }^{41}$

The reviews of the show are invaluable when assessing to what extent artists and scholars in Australia and New Zealand may have known about the Aesthetic Movement. Although the influences of Aestheticism were not overtly present in Australian art, or for that matter in New Zealand, at this time, it is clear that many antipodeans were aware of its basic characteristics. Sections of local newspapers were dedicated to reporting social gossip back 'home' in England and this reflects the degree to which colonists living in New Zealand saw themselves as an extension of the British Empire. Thus, figureheads such as Oscar Wilde and concepts indicative of Aestheticism were already familiar to many individuals living in New Zealand through the distribution of literature and touring theatre companies from England, the United States and Australia. It was not until the arrival of British loan collections at International Exhibitions in Australia and New Zealand that both colonies started to comprehend the holistic nature of Aestheticism in both art and life in Britain.

The first real signs of Aestheticism in the antipodes were evident at the opening of the Melbourne Exhibition of 1880. There was an interest in Minton's stall, which contained a large number of Anglo-Japanese porcelain vases, plates and antique statues. The stall was elaborately decorated with Chippendale furniture, tapestries and a large ornamental peacock. In addition to the introduction of decorative elements derived from the Grosvenor in London, newspaper articles on both sides of the Tasman noticed a certain shift of interest in 'new' literature being imported, to accompany artworks on display at the Melbourne Exhibition of 1880. It is recorded that

we have sent all our old-fashioned tomes to the second-hand booksellers, our Tom Jones and Mr. Chuzzlewit, and have ordered two yards of poetry of the 'fleshy school' to fill their vacant places, 'Swinburne', 'Rossetti', and 'Jones's'

41 'The Aesthetic Opera "Patience"', ES, 20 February 1882, 1. 
Nocturnes. We roar no more over Dickens and Tom Hood, but exchange them for 'the lilies and languor', 'the roses and rapture', of Swinburne. ${ }^{42}$

The interest in the 'Aesthetic' grew in popularity with the opening of the Grosvenor Gallery Inter-Colonial Exhibition of 1887, in Melbourne. At this time, there was an opportunity to display great masters of Modern English painting in the colonies and it attracted the attention of many, including members of Art Societies in New Zealand. At an Otago Art Society meeting convened on 18 November 1886, a letter from the Premier of New Zealand, Sir Robert Stout, was read aloud. Enclosed with this letter was a personal communication from Sir Coutts Lindsay regarding 'a proposed exhibition of English pictures, in the Colonies' ${ }^{43}$ Members of the committee, including landscape watercolourist William Mathew Hodgkins and the Head Art Master at the Dunedin School of Art, David Con Hutton, expressed their shared interest in Lindsay's proposal to display Aesthetic paintings in Australia and New Zealand. This correspondence with Lindsay, the founder and owner of the Grosvenor Gallery in London, demonstrates an awareness of the Aesthetic Movement and the Art Society's willingness to exhibit these works. The Otago Art Society recorded in their minutes,

that the letter of the Honourable the Premier enclosing that of Sir Coutts Lindsay be acknowledged, that Sir R. Stout be assured of the hearty cooperation of this Society in the scheme proposed and of their entire agreement with the valuable suggestions made by him in reference to the localization of the exhibition. ${ }^{44}$

Unfortunately, the opportunity to spread Lindsay's Aesthetic doctrine by enabling the Grosvenor to exhibit on New Zealand shores never eventuated. Despite this setback, I believe the intention of members of the Otago Art Society to consider such works is significant. It suggests a real interest in trying to understand the progressive nature of British painting and display, particularly at the Grosvenor Gallery in London.

The initial failure to secure an extension of British loan paintings from the Grosvenor Intercolonial Exhibition in Melbourne did not deter the Otago Art Society from

\footnotetext{
42 'The Melbourne Exhibition', Bruce Herald, 12 November 1880, 5 and Alexandra and Yea Standard, 5 November 1880, 3.

43 Kirby-Jane Hallum is currently researching the wives of New Zealand's Premiers, Julius Vogel, Robert Stout and William Pember Reeves. Stout's personal letters to Sir Coutts Lindsay supports her argument of an 'Aestheticised fetish culture' in New Zealand. See Kirby-Jane Hallum, Aestheticism and the Marriage Market in Victorian Popular Fiction: The Art of Female Beauty, London: Routledge, 2015. 44 'Otago Art Society Minutes Book 1886-1893', (Dunedin City Council Archives, Box 1).
} 
pursuing further opportunities to exhibit English pictures in New Zealand. In fact another opportunity arose only two years later. In October 1888 the President of the Otago Art Society, Hodgkins, urged officials in charge of British paintings touring Australia, both at the Melbourne Centennial Exhibition and in Sydney, to consider loaning works for display in Dunedin. ${ }^{45}$ He believed it was important for local artists and the New Zealand public to witness such masterful wor ks by the great 'modern' painters. His plea was published in the editorial pages of The Melbourne Argus and the Sydney Morning Herald. ${ }^{46}$ This support for Hodgkins's proposal in Australia led Government officials to intervene. A series of letters written to the Premier of Victoria by the Premier of New Zealand, Sir Francis Dillon Bell, resulted in a selection of key works by English painters such as Watts, Burne-Jones and Leighton being secured for display at the New Zealand and South Seas Exhibition the following year. ${ }^{47}$ Significantly, this was to be the first time Aesthetic paintings would be viewed by a New Zealand audience. More importantly, it was a chance for young artists to observe and learn from paintings by revered masters of the period. ${ }^{48}$

The New Zealand and South Seas Exhibition was officially opened to the public on 26 November 1889 to commemorate the 50th anniversary of the settlement of New Zealand as a British colony. The exhibition consisted of pavilions displaying the finest advances made in art and industry from New Zealand, Australia and England. Situated under the dome of the main exhibition hall was a grand statue of Queen Victoria on a pedestal carved from Port Chalmers stone. A photograph reveals an arrangement of native ferns and flowers at the foot of the statue. Surrounding the statue were mirrors imported from Henry Brooks \& Co., of Wellington, England and

\footnotetext{
45 'History of the Present Exhibition', Otago Witness [OW], 28 November 1889, 15. 46 'The New Zealand and South Seas Exhibition: The Closing Ceremony', Otago Daily Times [ODT], 21 April 1890, supplement, 1.

47 Premier of the State of Victoria, Australia, Duncan Gillies wrote: 'should any Australian Colony desire the loan of the articles for Exhibition, they should be considered available for that purpose'. Letter dated 28 May 1889, in Francis Dillon Bell, (Agent General, London), 'Correspondence and Consent to Display Sir Frederic Leighton's Phryne', 1889-90, (Wellington: National Archives [N. A.], Ref no. IA1 578).

48 The first international exhibition in New Zealand was opened in Dunedin, in 1865. This exhibition focused on promoting industry, trade and New Zealand's commercial relations with the rest of the world. See 'Opening of the New Zealand Exhibition', ODT, 13 January 1865, 4-5. Cited: Hocken's 'Scrapbook of New Zealand and South Seas Exhibition', (Dunedin: Hocken Library, MS-0451/038); Alfred Eccles, The First New Zealand Exhibition and Dunedin in 1865, Dunedin Crown Print, 1925, 5-6; Rebecca Rice, 'The State Collections of Colonial New Zealand Art: Intertwined Histories of Collecting and Display.' PhD Thesis, Art History, Victoria University of Wellington, 2010.
} 
archways framed with decorative hand-painted spandrels. This elaborate arrangement continued, as mentioned in the press, with Italianate Corinthian columns draped in rich velvet curtains. These details created a high-end aesthetic not too dissimilar to the elitist interior decoration of the Grosvenor in London.

The official catalogue for the exhibition provided a floor plan of the gallery spaces. ${ }^{49}$ Outside the principal art gallery there was a main corridor connecting with the Avenue of All Nations. Located within this corridor was the Monrad Collection of prints and according to Mathew Norman, the placement of Monrad's prints suggests their inclusion was a complete 'afterthought'. 50 The corridor provided access to the art galleries, which had been divided into six separate rooms; galleries I and VI contained works of Colonial painters with Galleries II, III, IV, and V containing the British loan collection of oil paintings and watercolours. ${ }^{51}$ Contractors responsible for the interior decoration of these gallery spaces wished to create an environment of luxury and sophistication. In order to achieve this aim the lower section of the walls, often referred to as the dado, was painted in an Indian red colour. For Prettejohn, the practice of differentiating the lower section of the wall was a key aspect of Aesthetic interior design. ${ }^{52}$ It is fascinating to see this detail implemented in New Zealand.

Several visitors to the exhibition found it difficult to discern the precise colour used on the walls, describing them as 'straw', 'buff' or 'light chocolate' in tone. ${ }^{53}$ The cornices and panel work were hand-painted in various tones to both complement and harmonise with the colour scheme of the walls and paintings. A frieze near the top of the wall was finished with a rich stencil pattern. This strong attention to detail suggests officials of the New Zealand and South Seas Exhibition wanted to emulate and uphold the aesthetic traditions admired in the great galleries of Europe. After all, for those visiting the exhibition, it would have been their first opportunity to view

\footnotetext{
${ }^{49}$ Floor plan in Official Catalogue of the New Zealand and South Seas Exhibition, held at Dunedin 188990, (compiled by D. H. Hastings), Wellington: Government Printer, 1891, 3.

50 Mathew Norman, 'Print Collection of Bishop Monrad (1811-1887)', M. A., Art History, Wellington: Victoria University of Wellington, 2006, 51-52.

51 Official Catalogue of the New Zealand and South Seas Exhibition, 2.

52 Prettejohn, Art for Art's Sake, 7.

53 'The Exhibition Building: Its Disposition Into Courts', ODT, 26 November 1889, 6; 'The New Zealand and South Seas Exhibition', Tuapeka Times, 14 December 1889, 4.
} 
works by the Victorian Aesthetes they had read about in magazines such as Punch. It was therefore appropriate to place these pictures amongst beautiful surroundings.

\section{WATTS AND LEIGHTON—AESTHETICISM AT THE DUNEDIN EXHIBITION}

The most 'curious' painting to arrive on board the SS Rimutaka from London was George Frederic Watts's The Spirit of Christianity, c. 1873-75 (London: Tate Britain).54 Located in Gallery II, this large allegorical painting was completed by a loyal Aesthete, commonly referred to as 'England's Michelangelo'. ${ }^{55}$ Despite Watts's reputation as one of the great artists of his generation, his allegorical representation of Christianity received mixed reactions from the general public. 56 Visitors to the exhibition were informed that this painting was not listed for sale as it had been bequeathed by the artist to the British Museum. A handful of observers expressed their relief at this arrangement, as they were completely against the idea of purchasing this 'detestable' painting for a New Zealand collection.

Irregularities with the colour scheme in Watts's Aesthetic painting proved too distracting for some onlookers. They voiced their concerns with the picture, calling it 'crude' and 'unpleasant' to look at. ${ }^{57}$ The style of the painting was not their only criticism. The large sculptural figure floating in the clouds appeared to be neith er male nor female. This blur between 'effeminate' and 'masculine' attributes was a key characteristic synonymous with Pre-Raphaelite and Aesthetic paintings in England. It is not surprising that a predominantly conservative New Zealand audience responded with such apprehension towards the androgynous figure. In response to the public's scrutiny and confusion surrounding Watts's painting, Hodgkins and Ross sought to enlighten the general public. Their critiques were published in December 1889 and expressed complete admiration for the artist's achievement.

\footnotetext{
54 'Exhibition Notes', ES, 30 July 1889, 2.

55 Wilfrid Blunt, A Biography of George Frederic Watts: England's Michelangelo, London, Hamish Hamilton, 1975, xvii.

56 Rebecca Rice has given two presentations on reactions to Watts's painting at the New Zealand and South Seas Exhibition. 'G. F. Watts's The Spirit of Christianity and the Role of British art at Colonial Exhibitions', AAANZ Conference, 2010; 'That Most Detestable Picture': Art and Emotion in NineteenthCentury New Zealand', History of Emotions Conference, Victoria University of Wellington, September 2015. Rice's argument proposed an artwork could inspire active dislike rather than just passive contemplation of beauty.

57 W. M. Hodgkins, 'The Exhibition', ODT, 2 December 1889, 2.
} 
With sorrowful expressions, the four chubby putti shelter below the red-cloaked figure on a bed of clouds. In the foreground a low horizon separates the divine figures from humanity below. Blended strokes of 'mystic' and 'dreamy' colours form what appear to be buildings and a cathedral spire. Ross believes the 'poetic truth' in this painting can only be achieved by a true master of art. The Spirit of Christianity delivered a symbolic message of beauty to worshippers of art and theology. However, Watts did not consider this painting to be a religious scene, claiming it was merely intended to act as a cautious reminder of an 'infinite' power. ${ }^{58}$ After all, Watts lived during a time of profound industrial expansion, secularisation and shifts in class structure. It marked a period of growing uncertainty in England. The strong symbolism in his painting served as a coded message from a humble servant of art; to portray power as greed. This underlying but ever-present message is reflected in Ross's final statement: 'G. F. Watts, the poet-painter of the present day, is in the front rank of living artists. He is at all events a genuine artist, and of him it can be said tr uly that he thinks only of Art for Art's Sake'. ${ }^{9}$ Despite Watts's lack of 'worldly goods', Ross believed the artist's legacy would be his dedication to upholding the autonomy of art. It is through these comments that the New Zealand-born and educated critic eloquently showed his awareness of the aims of Aestheticism and by doing so, he admires Watts's ability to present the truth of his practice through the lyricism of his brush.

Watts's tribute to 'the Infinite' was not the only picture capturing the attention of critics at the exhibition. In Gallery IV there was an allegorical scene by a fellow proponent of Aestheticism in England. Sir Frederic Leighton, the President of the Royal Academy in London and exhibitor at the Grosvenor, sent several works to be exhibited in Australia and New Zealand. One of the most prized at the international exhibition was Phryne at Eleusis, c, 1880-82 (untraced). ${ }^{60}$ The painting shows an

\footnotetext{
58 At the Royal Academy Exhibition (1875) this painting was entitled Dedicated to All the Churches; see, Mark Bills and Barbara Bryant, G.F. Watts, Victorian Visionary, New Haven and London: Yale University Press, 2008, 212.

${ }^{59}$ Malcolm Ross, 'The Art Gallery By M. R., II, George F. Watts and Edwin', ODT, 3 December 1889, 5. 60 Provenance recorded by Leighton House Museum shows Phryne was bequeathed by the artist to his sisters; sold through Christie's, London 13 July 1896 (lot 110); sold through Christie's, London 14 June 1902, (lot 79); sold through Christie's, London 21 June 1907, (lot 91); purchased by Sampson; current whereabouts is unknown. https://www.rbkc.gov.uk/lordleightonsdrawings/ldcollection/painting record.asp?workid=803. Accessed 3 November 2015.
} 
idealised female nude with her arms raised above her head in an iconic Aesthetic state of inactivity. Leighton chose to depict a significant moment at the festival of Poseidon, where the celebrated Greek courtesan of the fourth century B.C.E. reputedly disrobed among a vista of ancient Doric columns before walking into the sea at Eleusis. She was a true embodiment of beauty. Soft red drapery flows around the curvature of her smoothly rendered body and rests on the marble steps at her feet. ${ }^{61}$ In her right hand Phryne threads her voluminous, dishevelled length of auburn hair through her fingers, and with her left, she binds a traditional fillet (or headdress) around her head. Leighton's imposing figure embodies elements of pure beauty that mimic the statuesque idealism present in ancient Greek and Roman sculpture. The pose itself reflects Leighton's careful study of the antique, for example, the contrapposto of her body and elevated arms are reminiscent of Aphrodite Anadyomene (Rome: Museo Nazionale delle Terme). ${ }^{62}$ Over time, this pose evolved and was later used in other notable paintings by Leighton, including The Bath of Psyche, 1890 (London: Tate Gallery) and Phryne: The Arts of Industry as Applied to Peace, 1884-86 (London: Victoria and Albert Museum). In fact, the facial features of the female figure in his monumental scene The Arts of Industry as Applied to Peace share similarities with Phryne of 1882, demonstrating Leighton's use of the life model.

The Greek maiden Phryne is said to have been modelled after a non-professional English woman. It was common practice to find actresses and high-ranking women posing for artists. There was speculation that the mythical creature shared a striking resemblance to his muse Dorothy Dene, but was manipulated to give this character a 'brown-skinned' appearance. ${ }^{63}$ However, her exact identity has never been confirmed. Nevertheless, Pamela Gerrish Nunn believes the subject, the 'mythological nude', infamous at the peak of the Aesthetic Movement in the 1880s, was appreciated for being 'sensual, pseudo-historical and often very titillating, though elegant.' 64 Gerrish Nunn's point is reinforced when analysing Leighton's experimentation with

\footnotetext{
61 The use of 'unnatural' colours described by Charlie in 'Letters Home', ODT, 7 December 1889, 5. 62 Tim Barringer and Elizabeth Prettejohn (eds.), Frederic Leighton: Antiquity, Renaissance, Modernity, New Haven and London: Yale University Press, 1999, 31-33.

63 The Times, 1 May 1882, 4. Cited in Alison Smith, The Victorian Nude: Sexuality, Morality and Art, Manchester and New York: Manchester University Press, 1996, 168.

64 Pamela Gerrish Nunn, Victorian Women Artists, London: The Women's Press, 1987, 107.
} 
an Aestheticised formula in Phryne. The subject of a solemn-looking woman dressed in flowing drapery on the seashore became a popular scene for painters within Aesthetic circles. Notably, it was a subject revisited on numerous occasions by dedicated Aesthetes such as Leighton, Whistler and Albert Moore. Prettejohn believes paintings like Phryne reveal Leighton's conflicting attitudes or, as she likes to refer to it, his 'Janus-stance' on art. ${ }^{65}$ On the one hand, Leighton adhered to the traditions of History Painting while on the other, he produced Aestheticized scenes of young maidens caught in a transient wave of serenity, peace and music. Walter Hamilton remarked, although Leighton was not a proponent of the extremist end of the 'Aesthetic School', he spoke the Aesthetic language. ${ }^{66} \mathrm{He}$ advocated for an elevated and refined sense of beauty in art and life.

As a leading painter in Victorian England, Leighton stood at the threshold between Academician and Aesthete, the traditional versus the modern. His 'Janus-stance' was an 'act' for the betterment of art and formed a pathway for artists to embrace 'Art for Art's Sake'. Leighton's hesitancy about committing to the Aesthetic cause wholeheartedly may have had to do with the stigmatisation of the movement as 'effeminate'. In the 1870s and 1880s the cult of Aestheticism and its dictum promoting 'Art for Art's Sake' was associated with negative connotations of an incurable 'sickness' and 'indolence'. 67 The fact that Leighton never married has led some art historians to speculate about his sexuality. One contributor adding to this lively discussion, Keren Rosa Hammerschlag, argued that as an 'eligible bachelor' of revered stature, Leighton's paintings could be interpreted differently. Hence, 'to read Leighton's paintings of boys and men as evidence of his latent homosexuality, and his paintings of women as evidence of his misogyny and fear of female sexuality, is to simplify the complexity of his masculine identity'. ${ }^{68}$ Leighton held steadfast to the traditions of Academic painting. He continued to paint historical scenes in order to maintain a 'masculine' appearance in the public arena. Yet, Barringer and Prettejohn

\footnotetext{
65 Barringer and Prettejohn, Frederic Leighton, 89.

66 Hamilton, The Aesthetic Movement in England, 22.

67 Glazer and Merrill (ed.), Palaces of Art, 107.

68 Keren Rosa Hammerschlag, Frederic Leighton: Death, Mortality, Resurrection. British Art: Histories and Interpretations since 1700. Surrey, U. K.: Ashgate, 2015, 79.
} 
urge caution when discussing Leighton's supposed homosexuality, as biographical evidence about his sexual orientation has never confirmed these claims. ${ }^{69}$

Leighton persevered with his Aestheticised subjects of mythical goddesses and sleeping women during the 1880s. Phryne is a great example of the artist's continuation of an 'effeminate' Aestheticism. Her vacant expression, limited iconographical motifs and languid pose make it almost impossible for the viewer to identify her other-worldly status. This painting was composed to represent beauty. True to the aims of Aestheticism, Leighton had no intention of overtly presenting a historical narrative, but was more interested in appreciating the radiant beauty and contemplative demeanour of the female form. ${ }^{70}$

This aestheticised 'goddess' would soon cause quite a stir when she was placed on display in early November 1889 at the New Zealand and South Seas Exhibition, Dunedin. Leighton was recognised by many as the greatest 'decorative' painter of his generation and deemed a 'celebrity' in England's high society. When Phryne arrived at the Exhibition in late 1889, the painting was considered one of the finest in the touring British Loan Collection. Unbeknown to the public, it was uncertain as to whether Leighton's work would be shown in Dunedin. Due to an oversight by an official in Sydney, the whereabouts of Phryne was unknown for a short period of time. A collection of hand-written exchanges between the Agent General, Ingram, in Sydney, President of the New Zealand and South Seas Exhibition in Dunedin, John Roberts, and Leighton at Holland Park in London reveal tension over the mismanaged shipping arrangements that were not pursuant to the insurance policy. ${ }^{71}$

It was after several urgent telegrams between Dunedin and London that Leighton's Phryne was finally found to have been in crate 19 containing the Anglo-Australian collection sent directly from Sydney to Dunedin. Leighton was displeased with Ingram as the work had not been sent back to London on the SS Rimutaka as the artist had instructed. Leighton was insistent that the work not be displayed in Dunedin without his permission. The artist's reaction suggests this work was

\footnotetext{
69 Barringer and Prettejohn, Frederic Leighton, xiv-xv.

70 Smith, The Victorian Nude, 115.

${ }^{71}$ Correspondence between Francis Bell, John Roberts and Frederic Leighton on locating Phryne, 188990, (Wellington: N. A., Ref. IA1 578).
} 
invaluable to him. In an effort to keep the work, which ironically was already on display in Dunedin, Roberts sent a reassuring telegram to Holland Park in London. He notified Leighton that Phryne was hanging safely in a fire-proof gallery in Dunedin. It was not until 23 November 1889 that Leighton relayed his permission for the painting to remain on display in New Zealand. To Roberts's relief, Leighton believed the act of displaying his pictures in the antipodes had the potential to inspire young artists in both Australia and New Zealand. The Academician reiterated this point in a letter addressed to Sir Francis Bell in 1889, where Leighton offered his 'sincere desire to aid the cause of art amongst my brother Englishmen of the other hemisphere'. ${ }^{72}$

\section{GIROLAMO PIERI NERLI: AN ANTIPODEAN AESTHETE}

Leighton's wish for his work to facilitate discussion between artists in the antipodes was captured by the official photographer for the Exhibition, John Alexander de Maus [Plate 1]. His photograph shows a remarkable meeting that took place in front of Phryne. Italian-born artist Girolamo Pieri Nerli is seated next to the Art Master at the Dunedin School of Art, David Con Hutton. Both Nerli and Hutton appear to be analysing Leighton's depiction of an idealised beauty in her very elaborate bronzegilt frame. The photograph provides an extraordinary piece of evidence revealing Leighton's allegiance to the Aesthetic doctrine. The decorative frame shows a series of 12 sunflowers evenly spaced along the large and ornate border. Phryne takes pride of place on a feature wall with a plush crimson curtain resting behind her. The curtain separates this painting from other works, providing a setting of harmony and aesthetic clarity.

There is no definitive evidence revealing the thoughts these two artists expressed about Leighton's work. However, historical evidence of Nerli's interaction with avantgarde painters in Australia suggests it is probable that he would have been familiar with Leighton's reputation, as first and foremost a History Painter but also through the Royal Academician's affiliation with the Aesthetic Movement in England. By 1883, the Art Gallery of New South Wales (AGNSW) had purchased Leighton's Wedded, 1882 and Head from The Arts of Industry as Applied to Peace, 1883 (AGNSW,

\footnotetext{
72 Letter from Frederic Leighton to Francis Bell, 22 November 1889. (Wellington; N. A., Ref. IA1 578).
} 
Sydney). ${ }^{73}$ Evidently, Nerli would have been familiar with these two works of art in the New South Wales Collection. In his discussion with Hutton, Nerli may have made a connection between the similarities of the pose and facial features demonstrated in Leighton's The Arts of Industry as Applied to Peace and Phryne in Dunedin.

Nerli was visiting New Zealand as an exhibitor and spokesperson for the touring New South Wales Collection. Reviews of the New South Wales Court praised Nerli's ability to produce works deploying the technique macchie, or application of spots of pure colour found in contemporary Italian painting. One of the most talked about paintings in the New South Wales Court was Nerli's Bacchanalian Feast c. 1889 (AGNSW, Sydney), not only for its style but due to the fact it was omitted from the official catalogue. ${ }^{74}$ Its presence is confirmed by Alfred Henry 0'Keeffe's recollection of his first encounter with Nerli. They met at the Exhibition and the Italian artist took him to view the painting, which ironically changed O'Keeffe's initial perception of Nerli as a talented artist. ${ }^{75}$ However, some critics identified the significance of seeing such a progressive painting in amongst the abundance of landscapes presented in the New South Wales collection. It was celebrated for its 'variant' style of avant garde painting, never before seen in New Zealand, and which one critic claimed to be a new style starting to develop in the 'sister colony' of Australia. Nerli was experimenting with more than just 'Impressionistic' scenes presented in his Bacchanalian Feast. This 'blend' of art movements adopted by artists in Australia and New Zealand reinforces the contradictory and overlapped state of art in the antipodes at this specific moment.

Before visiting New Zealand in late 1889, Nerli associated with a circle of progressive artists experimenting with avant-gardism in Australia. Nerli had arrived in Melbourne with his Florentine compatriot, Ugo Catani, aboard the Calédonian in

\footnotetext{
73 P. A. Tomory and Anne Kirker, British Painting 1800-1990: In Australian and New Zealand Public Collections, Sydney: The Beagle Press, 1997, 123.

${ }^{74}$ Nerli painted five versions of this scene. Scholars differ on which of these paintings Nerli presented as part of the New South Wales Collection at the New Zealand and South Seas Exhibition, Dunedin (1889-90). Currie believes Bacchanalian Orgy, 1887 (AGNSW, Sydney) was the painting located at the Dunedin exhibition. However, Entwisle suggests it may in fact have been Bacchanalian Feast, c. 1889 (Auckland Art Gallery Toi o Tāmaki, Auckland). See Peter Entwisle, Michael Dunn and Roger Collins, Nerli: An Exhibition of Paintings \& Drawings, Dunedin: Dunedin Public Art Gallery, 1988, 107; Anthony Murray-Oliver, 'Art in New Zealand', New Zealand's Heritage, 3, 1972, 1198.

75 A. H. O'Keeffe, 'Art in Retrospect: Earlier Dunedin Days, Paint and Personality', Art in New Zealand, 47, March 1940, 160.
} 
November 1885. Setting sail from Marseilles, the two artists brought a vast collection of oil sketches by their Italianate artist-friends and continued to accumulate artefacts on their travels through Madagascar, Mauritius and the Bourbon (Réunion) Islands. Nerli and Catani's presence was noticed immediately. Local newspapers reported their delight in discovering the two Florentine artists had established a contemporary Italianate-styled studio environment in Collins Street West, Melbourne. The romanticism of their bohemian outlook and décor of the city studio intrigued various contemporary artists and patrons.

Catani occupied the studio in Collins Street, Melbourne until the early 1890s, but Nerli grew restless and towards the end of 1886, he moved to Sydney. During this time, Nerli's personality and talent made an impression on several members of a group that was later known as the 'Heidelberg School'. This group of plein air painters included Charles Conder, Arthur Streeton and Tom Roberts. Members of the Heidelberg School were known to experiment with painting techniques, form social gatherings to discuss ideas presented in art magazines and even share studios. It is only recently that art historians have realised that Nerli's association with these Australian artists was more significant than previously acknowledged. Nerli's friendship with Conder, and the fact these two artists shared a lavishly decorated studio in Sydney, reveal their common interest in establishing both a local and international confluence of predominantly Aesthetic ideals in this part of the world.

Australian art historian Bernard Smith believed that Phil May, a close associate of Conder and a designer for the Sydney Bulletin, was the first to impart knowledge of Whistler and the Aesthetic Movement to the colonies in 1886. However, with Nerli's arrival in Sydney that same year, the Italian artist conveyed his own pre-existing notions of an Italian variant of Aestheticism. The representation of art and life was an ideology adhered to by members of the Macchiaioli and the Scapigliati groups of bohemian painters in Italy. By the mid-1880s, both Conder and Nerli were aware of Aestheticism and its role of informing fashion and taste. They began to establish connections with wealthy clientele, such as the Master of Katoomba College, Blamire Young. ${ }^{76}$ These middle- and upper-class self-made men lived in urban commercial

\footnotetext{
76 Ursula Hoff, Charles Conder, Melbourne: Lansdowne Press, 1972, 15.
} 
centres in the antipodes and began to commission artists to decorate the interiors of their homes with hand-painted scenes and 'exotic' furnishings. Aestheticism began to thrive. The ideology spread and evolved across the South Pacific resulting in the promotion of beauty in art and the home. Wealthy businessmen started to build redbricked homes with luxurious interiors in urban centres such as Melbourne, Sydney and Dunedin. This influence would also inhabit the artist's studio: 'Show me a man's home and I will tell you his character is emphatically true of an artist's studio'.77

Between 1888 and 1889 Nerli shared a studio with Conder at Norwich Chambers in Sydney. During this period Nerli produced a painting that reflected his knowledge of Aestheticism and his desire to live amongst beautiful objects. This new ideology and lifestyle was clearly infiltrating the minds of intellectuals living in the antipodes. Aspects of Aestheticism, in this case, an interest in exotic artefacts, are presented in Nerli's The Sitting, 1889 (Brisbane: Queensland Art Gallery) [Plate 7]. Nerli's painting features an antipodean woman dressed in a light pink dress with a white ribbon accentuating her waist. The unknown model directs her gaze over to the right, presumably where the artist is sitting. Her gloved hands hold on to an intricately hand-painted Japanese silk fan. She is positioned off-centre to the left and is evidently not the focal point of this picture. Is she in fact a commodity herself? Scholars of gender studies believe capitalism precipitated 'the study of women as commodities' ${ }^{78}$ Kirby-Jane Hellum's Aestheticism and the Marriage Market in Victorian Popular Culture argues the presence of a woman in art took on a whole new meaning in the context of Aestheticism. ${ }^{79}$ The female subject became a sexuallycharged irresistible 'object' of desire. Nerli's audience becomes immersed in the ambience of The Sitting with luxurious objects and a fashionably dressed woman portrayed in the privacy of his studio.

The female subject is surrounded by 'decorative' objects specific to the Asia-Pacific region and Europe. A juxtaposition of paintings, wall hangings, a lion-skin rug, intricately patterned fabrics draped over the screen, and decorative fans from the Pacific Islands and Japan rest side-by-side on the walls of the studio. These objects,

\footnotetext{
77 Sydney Mail, 12 October 1889, 812. Cited: Astbury, 'Around the Studios', 64-69.

78 Hallum, Aestheticism and the Marriage Market in Victorian Popular Fiction, 7.

79 Ibid.
} 
sourced from local and international cultures, are arranged in bric-à-brac fashion-to create a 'harmonious' space of 'ordered disorder' that only an artist familiar with the latest Aesthetic fashions could envision. On the left, an Aesthetic decoration of a large bronze Minton vase contains a voluminous amount of pampas grass. To balance the composition, Nerli has covered the bronze-painted divan and a section of the wall with sumptuous Middle-Eastern carpets and an Anglo-replica of an oriental-styled rug.

Nerli is presenting his own vision of his studio. In The Sitting it becomes obvious that imitation of reality was not the aim of Nerli's painting. Instead, it was painted to celebrate the essence of the medium. On the right, there appears to be a large gold frame decorated with translucent daubs of paint, somewhat resembling a butterfly. This frame is severely cropped out of the composition. Placed above the settee are two small frogs hanging on the richly-coloured wall. In Japanese culture a frog symbolises safe travels and rebirth; a poignant token for Nerli starting a new life in the antipodes.

Nerli's brilliantly executed depiction of an antipodean studio is an evocative representation of what is thought to be Nerli's and Conder's studio at Norwich Chambers in Sydney. A newspaper article described the ambience of Conder's studio as:

attractively fitted up with soft draperies of Madras muslins, liberty silks, and other lightly falling fabrics, while souvenirs of Sydney are scattered over the room-sketches by Phil May, F. B. Schell, Mahony, Julian Ashton, Mills [Minns?], Nerli and Madame Constance Roth. Scraps of seascape, river views, and a few of the artist's own pictures are dotted about the walls among fans and other odds and ends of curious little articles that artists love and which go far in making the studio the picturesque little spot it is. 80

Curiously, within The Sitting, Nerli deliberately chose to centralise his own work The Ascension. Nerli's small sketch harmoniously rests amongst the other curios and luxurious decorations hanging arbitrarily on the wall. The presence of Polynesian fans, positioned to the left and central foreground of the picture, reveals an antipodean adaption of Aesthetic objects which instil a sense of beauty within the

80 Table Talk, 5 April 1889, 6. Cited: Andrew Montana, 'Arabesques of Beauty: Cullis Hill, the 9 by 5 Impression Exhibition, Decorative Decor and Painting', The La Trobe Journal, 2014, 85; Galbally, 'Aestheticism in Australia', 124-33. 
studio. Michael Dunn believes Nerli's choice of subject in The Sitting provides an insight into 'the fashionable interests of a young Aesthete; beautiful women, Japanese art, the exotic and the decorative'. 81 The inclusion of items from the Pacific Islands (where Nerli would later visit Samoa in 1892) shows his intention of allowing the artist's mind to retreat into a superior realm of the beautiful; an idea reminiscent of Whistler and his purpose for the Aesthetic studio environment. Nerli's Portrait of a Young Woman Artist, 1889 (Dunedin: Hocken Library) also depicts a female figure surrounded by 'exotic' objects from the Far East and the South Pacific region. Leigh Astbury has argued that although Nerli's studio did not try to systematically replicate Whistler's workshop in London, The Sitting irrefutably shows the artist's intention to create a cosmopolitan studio environment after the fashionable Aesthetic interiors in Europe. 82

Fellow artists working in Aestheticist circles in Melbourne, such as Tom Roberts, were also drawn to Aesthetic decoration in the studio. Roberts had one of the finest studios in Melbourne. The studio was elaborately decorated with hard-edged modern frames, soft draperies knotted around the edges of his paintings, Japanese screens, and fernery in vases. ${ }^{83}$ Within this studio Roberts painted his iconic Aesthetic portrait Blue Eyes and Brown, 1888 (NGV, Melbourne). Roberts's picture depicts the sorrowful eyes of a young girl with auburn hair as she rests on a bamboo chair dressed in a peacock-inspired garment of blue and green. An ochre-coloured screen behind her guides our attention towards the soft and lonely glance of the young girl. The presence of sorrowful women, Japanese motifs and decorative interiors, found in works produced by Roberts and Nerli, enables art historians to claim that Aestheticism had found its way to the antipodes during the late 1880s.

The 9 by 5 Exhibition was initially advertised to take place in Roberts's studio at the Grosvenor Chambers. However, the exhibition was relocated to Buxton's Galleries in Melbourne in August 1889. Recent scholarship by Andrew Montana and Leigh Astbury has proposed that Roberts was a leading figure when it came to designing the layout for the exhibition. In collaboration with the decorating firm Cullis Hill and

\footnotetext{
81 Entwisle, Dunn, and Collins, Nerli, 18.

82 Astbury, 'Around the Studios', 64.

83 Table Talk, 26 April 1889, 5. Cited: Astbury, 'Around the Studios', 66-67.
} 
Co., the organisers insisted the interior should be furnished with Chippendale, Bretby Jardinières, Liberty silks, and Japanese parasols, screens, and fans. ${ }^{84}$ Montana, Astbury and Galbally have agreed that the 9 by 5 Exhibition was 'staged-managed' by Roberts to attain an 'elixir of Aestheticism' 85

These exhibiting artists often painted en plein air in the countryside, as Helen Topliss has suggested in The Artists' Camps. They were asked to 'forsake their studios and set up easels in the countryside'. ${ }^{86}$ There is evidence to suggest these artists replicated the splendour of their studio environments in a rural setting within makeshift tents. Existing photographs and paintings of the artist's studio (like Nerli's opulent scene), however, also show that these artists actively 'touched up' paintings on easels within luxurious studios. The Heidelberg group would paint outdoors and then retreat inside to a sanctuary of Aesthetic delight in either a tent or studio.

Conder, Roberts and Nerli evidently shared a fascination for the 'exotic' in both Asia and the South Pacific. Ursula Hoff's examination of Conder's life in Australia and England proposes that his works inhabited both a local and international realm of importance. Conder's development as an artist was seen to be a 'combination of painting, music, of décor and poetry [that] is much in the spirit of the Aesthetic Movement, Art Nouveau and the desire for the "Gesamtkunstwerk" (the total artistic experience), so characteristic of the late nineteenth century'. ${ }^{87}$ Nerli's direct connection to progressive art circles in Australia made him a pioneering figure of art in the antipodes. However, Nerli was not the only important figure spreading the teachings of Aestheticism throughout the South Pacific. While Nerli was in Dunedin, a young Scottish-born artist associated with 'the Glasgow Boys' arrived and was invited to present a lecture. Nerli may well have attended as an honoured guest. It is at this lecture where the two artists would have met for the first time and openly discussed their artistic philosophy. The coincidental nature of their visits to Dunedin in 1890

\footnotetext{
${ }^{84}$ Arthur Liberty's department store opened Regent Street, London in 1875. Liberty's merchandise became an emblem of 'Aestheticism gone commercial'. In Fiona MacCarthy, 'The Aesthetic Movement', Guardian, 26 March 2011. http://www.theguardian.com/ artanddesign/2011/mar/26/aestheticismexhibition-victoria-albert-museum. Accessed: 7 August 2015.

85 Galbally, 'Aestheticism in Australia', 132; Andrew Montana, The Art Movement in Australia: Design, Taste and Society 1875-1900, Melbourne: Melbourne University Press, 2000, 110.

86 Helen Topliss, The Artists' Camps: Plein Air Painting in Melbourne 1885-1898, Melbourne: Monash University Gallery and The Visual Arts Board of the Australia Council, 1984, 7.

87 Hoff, Charles Conder, 39.
} 
led to an admiration for one another's work, as evident in Guy Morris's photograph, where the two artists are seen reunited in 1896 [Plate 8]. In this lecture presented in 1890, the young Glaswegian would impart his understandings of Aestheticism in Europe and his hope for it to prosper in New Zealand. 


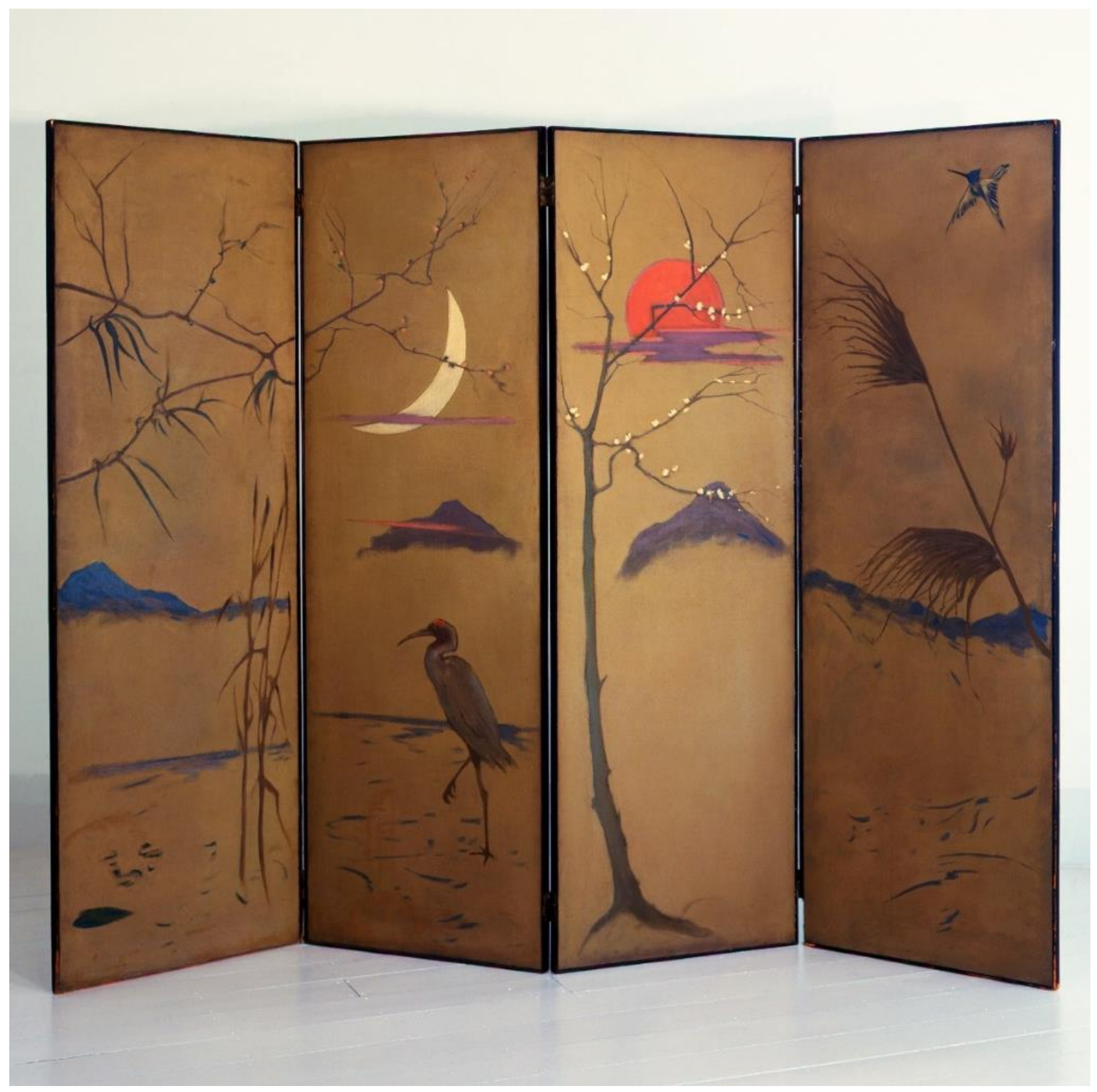

Plate 2: James McLauchlan Nairn, Sun and Moon-a Japanese Landscape, (verso) screen, oil on canvas, four framed panels, each 1727 x 559 mm, 1888 (purchased 1987 by the National Art Gallery, now Museum of New Zealand Te Papa Tongarewa). 


\section{Chapter Two}

\section{THE 'LOST' THOUGHTS OF AN ANTIPODEAN BUTTERFLY: J. M. NAIRN’S ‘DECORATIVE ART’ LECTURE OF 1890}

The year 1890 heralded a new era for painting practices and professionalism in New Zealand art. A few months after the Italian émigré Nerli arrived in Dunedin to display his 'colourful sketches' at the New Zealand and South Seas Exhibition, the Scottishborn painter James McLauchlan Nairn (1859-1904) reached Port Chalmers, on 2 January 1890.1 During Nairn's 100 days at sea on-board SS Forfarshire, the young member of the Glasgow Art Club (founded 1867) felt compelled to decorate the walls of his private cabin. This gesture did not go unnoticed by the ship's captain. In fact, upon arrival in New Zealand the captain of the Forfarshire, John Collingwood, entreated the art dealer and expatriate Scot McGregor Wright to accompany him to inspect Nairn's cabin. ${ }^{2}$ It is here that McGregor Wright first encountered the Glaswegian's work.

In his description of the cabin, Wright revealed that, while Nairn was at sea, he had decorated his cabin with atmospheric studies in peacock green, blue and gold; a palette revealing the artist's fondness for Jules Bastien-Lepage and James McNeill Whistler. Nairn's decision to surround himself with beautiful and idyllic scenes to achieve a heightened sense of 'escapism' reveals his admiration and knowledge of Aestheticism. It is his overwhelming urge to decorate a 'bland' interior space with vivid colours and the 'Decorative Art' lecture he delivered shortly after his arrival in Dunedin which supports this notion of Nairn being identified as a true 'Antipodean Butterfly'.3

\footnotetext{
1 First mention of James M. Nairn on the SS Forfarshire (Glasgow en route to Dunedin) in 'Shipping', ODT, 12 December 1889, 1.

2 A. A. St. C. Murray-Oliver, 'Brief Notes on James McLauchlan Nairn, Artist', 24 July 1939, 1. (Wellington: ATL, qMS-1402).

3 I am grateful to Assoc. Prof. Alison Inglis for suggesting the term 'Antipodean Butterfly'.
} 
Nairn, described as a 'saloon passenger' in the ship's inventory, had even taken the liberty of painting a life-size study of Captain Collingwood on his wall. ${ }^{4}$ It is not known whether Collingwood was more outraged by the 'vandalism' to his vessel or was simply offended by Nairn's unseemly depiction of the captain. Nevertheless, Collingwood made his displeasure known to Wright and Nairn, labelling the artist as 'stark, staring mad'. ${ }^{5}$ Despite the captain's hostility towards Nairn, Wright was more welcoming of this bohemian's new approach to painting with daubs of pure colour and his artistic philosophy: Art for Art's Sake.

This anecdote reveals Nairn's bohemian spirit. During his time in New Zealand, Nairn provided a dignified response to those who did not yet understand him or his mission to paint for its own sake. The artist was constantly defending his artistic philosophy, which was a revelation to many in the 1890s. Before Nairn's arrival, landscape painters such as William Mathew Hodgkins, John Gully and J. D. Moultray were painting romantic 'Turneresque' landscapes of Mitre Peak in Milford Sound. ${ }^{6}$ It was commonplace to find romantic landscape scenes occupying at least half of the wall space at annual exhibitions. ${ }^{7}$ According to Nairn, 'true' artists of British and French landscape painting, such as John Constable, Jean-Baptiste-Camille Corot and Cecil Lawson, would never elect to paint such 'amateurish' scenes..$^{8}$ Nairn's new vision and artistic direction for New Zealand painting meant he was often criticised and labelled a reckless 'dauber'.

Despite the onslaught of criticism, Nairn stated, 'I shall always make a point of trying to outrage the taste of the ordinary public, as I don't want them to like my work'. ${ }^{9}$ This is a classic avant-garde position fostering a set of conventions and skills that only a select group identified with. Maurice Crompton-Smith (1864-1953), a pupil of Nairn at the Wellington School of Design, revealed the duality of his master's character and artistic ability. In a letter to a close friend, he recalled '[Nairn] lived life

\footnotetext{
4 'Arrival of the Forfarshire', ODT, 4 January 1890, 1 and 'Shipping', ES, 4 January 1890, 2.

5 'All Sorts of People', Free Lance, 5 March 1904, 3.

${ }^{6}$ E. H. McCormick, The Expatriate: A Study of Frances Hodgkins in New Zealand, Wellington: New Zealand University Press, 1954, 15; W. M. Hodgkins, 'A History of Landscape Art and its Study in New Zealand', ODT, 20 November 1880, Supplement, 5.

7 'The Late Mr Nairn', EP, 26 February 1904, 5.

8 J. M. Nairn, 'Some Notes on Landscape Painting', New Zealand Mail (NZM), 23 April 1896, 13.

9 Letter from James M. Nairn to Mabel MacIndoe (née. Hill), 19 August 1898, (Wellington: ATL, MSPapers-5581).
} 
to the full intensely. The clay and the gold both interested him, perhaps the clay more'. ${ }^{10}$ This statement alludes to Nairn's inherent ability to practice both 'high' and 'low' art forms. ${ }^{11}$ The colour 'gold' was associated with wealth and opulence, and therefore Crompton-Smith might be referring to Nairn's 'highbrow' status as an artist participating in the upper echelons of society. Nairn was after all recognised as a leading portrait painter in New Zealand and established close professional relationships with wealthy patrons. Although the records of the Académie Julian for the period prior to 1890 were completely destroyed during World War II, ${ }^{12}$ art historians tracing the 'darkly muffled section' of Nairn's early career have tentatively established that he studied at this prestigious art school, in Paris, during the early-tomid 1880s.13 This point supports Nairn's conventional teaching methods; instructing his students to uphold the Academic tradition of learning how to draw first.

Additionally, from Crompton-Smith's reference to the term 'clay', it is reasonable to deduce his awareness of Nairn's experimentation in 'low' art. Nairn endeavoured to paint the landscape en plein air (in the open air) with broad brushstrokes of vivid colour and study nature with his fellow bohemian artists for very little monetary reward. His 'open-hearted' generosity with time and 'open-handedness' with lending money to friends (which he could ill-afford to do) demonstrated Nairn's decision to embrace the lifestyle of a bohemian painter. ${ }^{14}$ He appreciated beauty above all other virtues: a lesson idolised and reiterated in Walter Hamilton's The Aesthetic Movement in England.

The flexibility of social class and moderate displays of wealth in New Zealand enabled Nairn to live a care-free bohemian lifestyle that differed from the class disparities in the Old World system. The artist could socialise with the lowest and highest levels of

\footnotetext{
10 McGregor Wright to Stanley Edwards, 22 June 1939 (Wellington: ATL, MS-Papers-1438).

11 In conversation with Roger Blackley, he suggested Crompton-Smith might be referring to Nairn's versatility as both a portrait and landscape artist: a painter of high and low forms of art. Quoted from Crompton-Smith Papers (Wellington: ATL, MS-Papers-1438).

12 'Archives de L'Académie Julian', 1890-1928 (Paris: Archives Nationales, 63 AS). Cited: H. Barbara Weinberg, The Lure of Paris: Nineteenth-Century American Painters and their French Teachers, New York: Abbeville Press, 1991, 222.

13 Scholars continue to deliberate when Nairn may have visited the Continent. Rice speculates that Nairn visited Paris in 1880-81, whereas Hearnshaw and Pound believe Nairn visited Paris in 1882-83. See Rice, 'The State Collections of Colonial New Zealand Art', 172; Hearnshaw, 'James McLauchlan Nairn', 2 and Pound, Frames on the Land, 86.

14 'All Sorts of People', FL, 5 March 1904, 3.
} 
society. This 'overlap' in society often gave the appearance that Nairn was communicating in different artistic languages, or living in separate 'artistic' spheres. He embraced both the 'gold' and the 'clay': a characteristic which truly epitomises Nairn's posthumous reputation as 'a disciple of Whistler'. ${ }^{15}$ In the end, CromptonSmith argued that Nairn preferred the 'clay' more. The artists belonging to the 'inner circle' believed, without proper artistic training, the ordinary public and art critics were not in a position to be making judgements on art. 16 To protect the autonomy of art, Nairn believed the distinction between 'good' and 'bad' art should be left to his 'brother artists' to critique and discuss. This elitist mentality was a key feature of the Aesthete: a belief which Nairn held on to throughout his career. Therefore, only a specific audience would be able to understand the true aims of 'decorative' art.

The term 'decorative' gained notoriety among young bohemian artists practising in London, Paris and Glasgow during the late 1880s. During this time, Nairn was a promising young member of the Glasgow Art Club. He trained under the guidance of Robert Greenlees and took additional life-drawing classes in the independent studio of William York MacGregor, a founding member of the Glasgow Boys. ${ }^{17}$ MacGregor's studio was a well-known meeting point or 'smoking room' environment for the Art Club members. It was a place of informal discussion about new techniques emerging out of the studios in London and Paris. This is where Nairn's interest in artists such as Whistler and Bastien-Lepage began. Ironically, both of Nairn's teachers adopted a balanced mind-set towards the study of art. MacGregor counselled against following any schools in art. ${ }^{18}$ Instead, he emphasised the importance of upholding the integrity of drawing from life while also embracing new artistic methods. Adherence to traditional art practices, while accepting 'modern' advancements, proved to be a

\footnotetext{
15 Murray-Oliver, 'Brief Notes', 2.

16 With the rise of art critic, the artist began to sense a shift in power. Nairn's stand against the 'philistine critic' is reminiscent of Whistler's conflict with the aging art critic, John Ruskin. In defence of his artistic philosophy, to paint Art for Art's Sake, Whistler raised his ideas during a civil trial in 1878 against Ruskin, who famously slandered Whistler for'flinging a pot of paint in the public's face'. Whistler claimed those who were not a part of 'the cult' would not be able to see the artist's 'true' depiction of Nature. See Kanopy Film Production, Whistler: For Art's Sake, 2014. https://vuwkanopystreaming-com.helicon.vuw.ac.nz/video/whistler-arts-sake. Accessed: 3 January 2016. 17 Keith, 'James McLachlan Nairn 1859-1904', 5.

18 Roger Billcliffe, Pioneering Painters: The Glasgow Boys, Glasgow: Kelvingrove Art Gallery and Museum, 2010, 125.
} 
great influence on the development of Nairn's approach to painting while in Scotland and later in New Zealand.

It is on the strength of Nairn's association with the Glasgow Boys that, following his arrival to Dunedin in January 1890, the writers of New Zealand's art history have chosen to identify him as the harbinger of Impressionism in this country. Art historian E. H. McCormick was the first to describe Nairn as an Impressionist painter in his 1940 book Letters and Art in New Zealand. However, more recent art historians, including Pound, Michael Dunn, Roger Blackley, Jane Vial, and Rebecca Rice, have not been so forthcoming with definitive statements about Nairn and Impressionism in New Zealand's art history. Instead, they have collectively crafted a biography of the artist, suggesting Nairn brought an 'attenuated' form of a so -called 'Impressionistic' style to New Zealand. Jane Vial explains that, while Nairn may not be an Impressionist in the French sense of the term, the artist certainly did bring aspects of the movement to New Zealand.

This Impressionist sensibility has been explored in Michael Dunn's assessment of Nairn's early years in Glasgow. His research, published in The Bulletin of New Zealand Art History, referred to a rare street scene painted by Nairn, who at this time was a young artist considered to be on the fringes of the Glasgow Boys. ${ }^{19}$ As Roger Billcliffe has noted, it was uncommon for this group to represent their own city on canvas. In Pioneering Painters, Billcliffe claimed Nairn's West Regent Street, 1884 (location unknown] [Plate 9] was an exceptionally rare example of an artist depicting urban streets of industrial Glasgow. ${ }^{20}$ In essence, the artists of 'the Glasgow School' were more inclined to escape the thick yellow haze shrouding the inner city to represent the clean, idyllic lifestyle found in the countryside.

A black and white photogravure of Nairn's West Regent Street, published in The Glasgow Art Club Book, confirms the significance of his cityscape. The book mainly comprises genre scenes in the style of the Dutch Hague School and their 'cult' hero, Jules Bastien-Lepage. Nairn's contribution to the book was a rare exception. The

\footnotetext{
19 Michael Dunn, 'Notes on Nairn in Glasgow', Bulletin of New Zealand Art History, 5, 1977, 11-14. 20 Billcliffe, Pioneering Painters, 78. The whereabouts of the original is unknown, but a black and white reproduction of the painting exists in The Glasgow Art Club Book, 1885, 176 (Glasgow: National Library of Scotland).
} 
scene overlooks a public sidewalk from an elevated window (which is most likely to be Nairn's private residence and studio] [Plate 10]. ${ }^{21}$ In the street below are gas-lit streetlamps, pedestrians walking with umbrellas and the reflection of water underfoot on the pavement. This composition of West Regent Street shares characteristics with the Impressionist painters of Paris. For example, Nairn's use of an elevated viewpoint, high horizon line, choice of subject matter, spatial recession of line, and exaggerated perspective are all aspects often found in works produced by the French masters of plein air painting. It has been speculated that Nairn may have been inspired to paint this street scene after viewing 'true' Impressionist paintings by Claude Monet exhibited in Paris or London between 1882 and 1883. ${ }^{22}$ Exposure to such masterful works by Monet (and possibly other less er-known Impressionist painters such as Gustave Caillebotte) prompted Nairn to paint what he saw below his studio window in Glasgow. ${ }^{23}$ West Regent Street is a voyeuristic scene. With its high viewpoint, Nairn makes the viewer feel as though they are an anonymous spectator, observing the people below going about their daily tasks. The high quality intaglio print in the Art Club Book revealed Nairn was experimenting with elements of Impressionist painting - that is, the immediacy of light, atmospheric effects and capturing a fleeting moment in real time.

Nairn's West Regent Street is a fine example of his early work in Glasgow and provides an appropriate point of reference when examining the artist's background and his subsequent place in New Zealand's art history. It is not my intention to deny Nairn's connection with the plein air tradition. Indeed, it is necessary to acknowledge the Impressionist credentials that are clearly represented in his early works in Glasgow and the landscapes he produced (after 1891) at locations such as Pumpkin Cottage in Silverstream near Wellington, New Zealand. But it is also necessary to reassess how we perceive this artist and his contribution to New Zealand art in this period. For example, there is a mysterious work by Nairn which represents a very different approach, one that art historians have chosen to leave unaddressed.

\footnotetext{
21 In 1887, Nairn lived at 144 West Regent Street, Glasgow. See Colin McCahon, James Nairn and Edward Friström, Auckland: Auckland City Art Gallery, 1964, 12.

22 Pound, Frames on the Land, 86.

23 Dunn, 'Notes on Nairn in Glasgow', 11-14.
} 


\section{NAIRN'S SCREEN-'À LA WHISTLER'}

Nairn and his 'brother' artists of the Glasgow Art Club shared a fondness for the French rural painters of Naturalism and the Barbizon School. The influence of Jules Bastien-Lepage on the Glasgow Boys was immense. Bastien-Lepage excelled in drawing and trained under the guidance of Alexandre Cabanel in Paris. At the Paris Salon in the 1870s, the young academician impressed. Bastien-Lepage showed great potential and raw talent through his ability to paint exquisitely detailed large-scale historical paintings. It was years later, after several failed attempts to win the Prix de Rome, that Bastien-Lepage retreated to the idyllic and reclusive surroundings of Damvillers. His rural landscapes were often displayed at the annual exhibition of the Glasgow Institute of Fine Art (founded 1861). It was through the generosity of wealthy local collectors that artists in Glasgow, including Nairn, would benefit from exposure to original works by the great modern painters of his generation.

The works of English, French and Dutch painters became popular acquisitions for local Scottish collectors and were frequently loaned to the Institute. Revered artists featured at the Institute included: John Constable (1776-1837), George Frederic Watts (1817-1904), Edward Burne-Jones (1833-1898), Anton Mauve (1838-1888), Josef Israels (1824-1911), Jacob Maris (1837-1899), Jean-Baptiste Camille Corot (1796-1875), Charles-François Daubigny (1817-1878), and Jean-François Millet (1814-1875). However, the most influential painter that young Glasgow artists epitomised as a 'true' artist, one who was faithful to serving art for its own sake, was the founder of Naturalism, Bastien-Lepage.

Nairn's admiration for characteristics of the 'Pre-Impressionists' paintings, particularly those of Bastien-Lepage, was demonstrated in a 'decorative' object. His hand-painted screen entitled Sun and Moon-a Japanese Landscape, 1888 (Museum of New Zealand Te Papa Tongarewa) [Plate 2] was commissioned by Dr James Cumming, a general practitioner living in Glasgow. Nairn was asked to produce a free-standing partition that most likely resided in Cumming's medical practice. ${ }^{24}$ With an increasing middle-class population in Glasgow, many young artists were asked to

\footnotetext{
24 Anne Kirker, 'Special Feature, The Nairn Screen: A New Acquisition', National Art Gallery Newsletter, April-June 1988, 6-7.
} 
accommodate the demand for 'decorative' works of art in homes, public buildings and business environments. This project differ ed from Nairn's common art practice; that is, as a painter of 'Impressionistic' landscapes with vibrant daubs of pure colour. Instead, his hand-painted screen features two very different subjects on opposing sides. On one side, the four-panel screen features an arrangement of a setting sun and crescent moon, a series of mountain ranges, studies of vegetation, and a cran e and hummingbird; all clearly influenced by Japanese design. The opposing side features four female figures allegorising the Four Seasons in the stylistic tradition of Jules Bastien-Lepage. What is truly fascinating about the screen is that the style and iconography directly reference the Aesthetic Movement.

Nairn's knowledge of other 'modern' art movements during the late 1880s and early 1890s is confirmed by Crompton-Smith, a pupil and close friend of Nairn. Although he never saw this hand-painted screen, Crompton-Smith did recall his initial observations of Nairn's early sample of works in New Zealand:

He [Nairn] was an artist to his fingertips, his hands were those of an artist, shapely, long and clever fingers. I have seen some of his work done when he first came out, very different from his later and well-known style, carefully and closely worked out in details - every stone in a river bed I remember. ${ }^{25}$

Crompton-Smith suggests that the works Nairn produced within the first few years of living in New Zealand differed from his later, more well-known landscapes and portraits. This initial observation of Nairn's use of restraint in his paintings is clearly evident in his stylised Japanese landscape spread across all four vertical panels. The contrast between the varying shades of blue hues on the clay-toned background is striking. At the top of one panel, a glowing orange disc alludes to a setting sun behind a dusky haze of cloud. To the left, Nairn paints the last phase of the moon for the season. Below the crescent-shaped moon, a crane appears to be walking from right to left across the lower section of a panel. On the far right a hummingbird is placed in

25 M. Crompton-Smith, 'Correspondence with Stanley Edwards', 10 July 1939 (Wellington: ATL, MSPapers-1438). 
full flight. ${ }^{26}$ Nairn's Japanese landscape is loosely arranged, yet the composition is harmonious and balanced: a key feature of Japanese design.

The illogical configuration of this scene suggests it depicts a realm of fantasy: an imagined Japanese landscape fashioned from the artist's mind. It is not an accurate scene of a specific place. The floating 'snapshots' of iconic symbols found in Japanese culture reflect Nairn's interest in Japonaiserie, a European style derived from an appreciation of Japanese art. Although he had never travelled to Japan, this did not deter Nairn and his 'brother' artists in Glasgow from envisioning the wonders of Japan. Nairn's ambition to visit Japan was recorded in The Bailie, a Glasgow social magazine. As he departed for Dunedin on 15 September 1889, it was reported that Nairn intended to visit Japan and the Pacific region on the return voyage (which never eventuated as Nairn succumbed to his illness). ${ }^{27}$ But why was there such a desire to visit Japan and how did Nairn find the inspir ation or envisage the mountains, trees and bird-life of a distant land he had never visited?

Nairn was not alone in his desire to one day visit the 'exotic' islands of Japan. During the 1880s, the economic prosperity of Glasgow grew, allowing it to be recognised as the Second City of the Empire. The wealth of the city expanded through trade, resulting in the rise of upper-and middle-class collectors of oriental art. Increasing trade with Asia made the resources of this richly cultured and 'mysterious' continent accessible to the second-largest industrial centre in Europe. A flourishing art market in the west of Scotland began to surge during the late 1880s with the return of a prominent Scottish art dealer, Alexander Reid. His presence had a profound effect on Glasgow's brotherhood of artists.

Reid returned to Glasgow in March 1889 after his once-close personal and working relationship with Theo and Vincent van Gogh ended. ${ }^{28}$ In Paris, Reid had lived with the van Gogh brothers for approximately six months, in their small apartment at 54 rue Lepic. It seems that over time Reid grew accustomed to Vincent's romantic vision

\footnotetext{
26 I am indebted to Dr. Colin Miskelly, Curator of Natural History at Te Papa Tongarewa, for his observation that a hummingbird is not native to Japan. It is a New World Species commonly found in the Americas. He suggested this bird is likely to be an 'artistic invention'.

27 The Bailie, 11 September 1889. (Nairn, Scrapbook, Wellington: Te Papa).

28 Frances Fowle, Van Gogh's Twin: The Scottish Art Dealer Alexander Reid, Edinburgh: National

Galleries of Scotland, 2010, 26.
} 
of making the south of France his 'absolute Japan'. In a letter, Vincent professed 'For my part I don't need Japanese pictures here, for I am always telling myself that here I am in Japan'. ${ }^{29}$ Vincent perceived Japan to be not only a beautiful foreign oasis but a state of mind, almost a religion. Despite never visiting Japan, Vincent convinced himself that he was living in a Japanese paradise: Arles became his spiritual utopia.

This spiritual mindset is prevalent in his Self-Portrait as a Bonze, 1888 (Fogg Art Museum, Cambridge, Mass.), where he personifies himself as a Japanese bonze or monk. In his portrait, dedicated to close friend Paul Gauguin, he manipulated the facial features. Vincent accentuated the slant of his eyes, flattened the bridge of his nose and rounded his head. He imagined himself to be a disciple or prophet of a new theology in art. In a letter to Gauguin, Vincent recalled his artistic awakening in his 'Japon' in the south of France and asked his friend to join him. Art historian Tsukasa Kōdera believed Vincent wished to establish an 'atelier du Midi' or a 'brotherhood' of artists at Arles. ${ }^{30}$ Gauguin, however, did not share Vincent's enthusiasm in making this location his permanent home, nor did he feel inclined to stay in Arles for very long.

Vincent van Gogh was not alone in his endeavour to find an ideal setting on the Continent, to equal, if not surpass, the beauty of Japan. When Reid returned to Glasgow in 1889 to open his art dealership, he too endorsed the mentality of immersing the public in a realm of ideal beauty. Reid's mission was to expose a new audience to the finest Japanese works. The first exhibition held at his dealer gallery, La Société des Beaux-Arts, comprised a selection of authentic Japanese prints, including some by the celebrated Katsushika Hokusai (1760-1849). The gallery, located at 227 West George Street, was a short walk away from Nairn's last known street address in Glasgow. It is plausible that Nairn would have discussed the opening of Reid's gallery with his friends before leaving Glasgow in September 1889. As the director of La Société des Beaux-Arts, Reid formed close relationships with members of the Glasgow Art Club, especially Henry and Hornel. Reid supported these local

\footnotetext{
${ }^{29}$ Letter from Vincent to his sister Wilhelmina van Gogh, Arles, 9 and 16 September 1888. Cited: Tsukasa Kōdera, 'Japan as Primitivistic Utopia: Van Gogh's Japonisme Portraits', Simiolus: Netherlands Quarterly for the History of Art, 14, 3, 1984, 208.

30 Vincent wanted to build on this idea first realised by the Pre-Raphaelites in England and wished to make a small community of artists in Arles a reality. See, Kōdera, Japan as Primitivistic Utopia, 201.
} 
artists to such an extent that, in 1893, he financed a trip to Japan for the two Glasgow Boys. ${ }^{31}$ His gallery became an artistic and spiritual haven for local collectors and artists to source and be inspired by Japanese prints and design.

Reid would have disclosed his own personal experiences of the fashionable events taking place in 'the Art Mecca' of Europe. A popular social event in Paris during the 1890s was the fancy-dress costume balls, where attendees would be expected to dress as famous artists like Velázquez or a subject taken from one of his paintings. ${ }^{32}$ On 29 November 1889, only two months after Nairn's departure for New Zealand, the members of the Glasgow Art Club organised a fancy-dress ball. John Lavery, dressed as Rembrandt, setup a makeshift studio at the venue to paint guests in their costumes. His Hokusai and the Butterfly, 1889 (National Galleries of Scotland, Edinburgh) depicts Edward Arthur Walton (1860-1922) dressed in a kimono as Hokusai, the leading ukiyo-e painter, while his fiancée Helen Law was in costume as 'Whistler's Butterfly': the butterfly representing a monogram devised by Whistler as his artistic signature [Plate 11]. Other guests chose to dress as Whistler, replicating his trademark features. For example, several artists wore monocles, three-piece suits and a ribbon tied around a white tuft of hair. These fashionable events allowed an individual to dress up and, for a short period of time, escape reality. As a social event, it promoted an awareness for art and culture while also promoting Reid's commercial ventures in Japanese art. ${ }^{33}$ If it were not for Nairn's sudden departure on 21 September 1889, he would surely have attended this playful 'Aesthetic' affair .

Nairn's screen indicates he was already responding to a moment where the Glasgow Art Club members were intrigued by the novelty of Whistler, Aestheticism and Japanese art. In the 1880s, rumours about Whistler's practices in London had spread to the studios of Glasgow and by 1884, his Arrangement in Grey and Black, No. 2: Portrait of Thomas Carlyle (1872-73, Kelvingrove Art Gallery and Museum, Glasgow) was 'skied' at the annual hanging of the Royal Scottish Academy. ${ }^{34}$ In the same year

\footnotetext{
31 William Buchanan, Mr Henry and Mr Hornel visit Japan, Edinburgh: Scottish Arts Council, 1979, Fowle, The Scottish Art Dealer, 55-56; Billcliffe, Pioneering Painters, 72-75.

32 I am grateful to Roger Blackley for enlightening me on his research in relation to the 'vogue' for dressing up as famous artists such as Rembrandt, Velasquez or Whistler in 1890s Paris.

33 Fowle, The Scottish Art Dealer, 55.

34 Ibid, 76.
} 
that Whistler's painting went on display, Nairn asked his father if he could paint his portrait [Plate 12]. Portrait of Archibald Nairn, Esq., 1884 (Museum of Te Papa Tongarewa, Wellington) shows his elderly father sitting in profile with his hands gently clasped against a plain wall; reminiscent of the pose, setting and restrained colour palette found in Whistler's Arrangement in Grey and Black series. Diverging from Gustave Courbet's Realism, Whistler adopted a non-literal approach to painting people and the landscape. Sidney Colvin described this shift as a conscious decision by the artist to paint 'beauty without realism'. ${ }^{35}$ Whistler's alternate style, formidable personality and revitalisation of art through a new artistic philosophy was greatly admired by the Glasgow Boys, especially James Nairn.

Whistler reiterated that art needed to be subdued, simplified and, most of all, beautiful. These components of making great art are connected to his obsession with oriental porcelain, embroidered silks and ukiyo-e-prints. Japonisme transfixed the imaginations of the Glasgow Boys. This was demonstrated in paintings produced by Nairn's friend, John Lavery. Woman in a Japanese Dress, 1883 (Yale Center for British Art, New Haven) and $A$ Visitor, 1885 (National Gallery of Ireland, Dublin) reflected the 'advanced' methods of Whistler's practice and an interest in 'exotic' cultures slowly enticing creative minds in Glasgow at this time. Lavery's studio at 248 West George Street, only a few buildings away from Reid's gallery, was lavishly decorated with Japanese fans and prints. Nairn and his 'brother' artists in Glasgow also read about oriental art in Whistler's famous Ten O'Clock Lecture, published in 1888. In this lecture, Whistler endorsed the simplicity of line and colour found in Japanese art. This lesson was implemented in both Whistler's and Nairn's experimentation with a limited palette of no more than three base colours and a decision to paint directly onto a screen.

Whistler took inspiration from the Far East and became the 'first western screenmaker to experiment with the concept of a folding image'. ${ }^{36}$ One of Whistler's early Nocturne studies was hand-painted on the reverse side of a two-panelled folding

\footnotetext{
35 Sidney Colvin, English Painters in 1867', Fortnightly Review, 1 October 1867, 473. Cited: Prettejohn, Art for Art's Sake, 112.

36 'Whistler, James McNeill', Hunterian Art Gallery Whistler Collections. http://www.huntsearch.gla .ac.uk/cgiin/foxweb/huntsearch/Detailed Results.fwx?collection=whistler\&SearchTerm=46379\&reqM ethod=Link. Accessed: 19 November 2015.
} 
screen [Plate 13]. Whistler purchased a screen, which on one side, had already been decorated with a Japanese landscape scene of birds and blossom trees designed by a female Japanese artist, Osawa Nampo. Whistler decided to paint a 'decorative' study of a moonlit night overlooking the Thames River, entitled Blue and Silver: Screen with Old Battersea Bridge, 1871-72 (Hunterian Museum and Art Gallery, Glasgow) on the opposing side of the screen. Initially, Whistler intended to sell the screen to his patron, Frederick Leyland (an art collector and owner of the controversial Peacock Room designed by Whistler), but later chose to keep the screen for his own pleasure. ${ }^{37}$ This Aestheticised object, inspired by and partly created in the Far East, was ultimately designed by the artist to satisfy his 'incurable thirst for a sense of escape'. 38 There is uncertainty surrounding how and where Nairn discovered this idea of painting directly on to the four framed wooden panels. However, following my observations of Nairn's screen, depicting a Japanese landscape on one side and a European scene on the other, it would be impossible to say this arrangement was not in some way inspired by Whistler's Anglo-Japanese screen.

The subjects represented on both sides of Nairn's screen reflect his interest in the confluence of East and West. A common feature on the opposing side of an Aestheticised screen was the depiction of genre scenes set in ancient Greece and Rome, mythological stories, or symbolic representations of women as the seasons. ${ }^{39}$ The latter featured prominently on the reverse of Nairn's screen, entitled Four Seasons [Plate 14]. From left to right, the figures representing Spring, Summer, Autumn, and Winter show very little emotion. Their dispassionate expressions resonate somewhat with the solemn demeanour presented on the faces of BastienLepage's figures, for example, the young boy in Pas Mèche, 1882 (Scottish National Gallery, Edinburgh). However, when examined more closely, the way in which Nairn has painted the four women with broad brushstrokes does not pay homage to the fluid technique we often associate with Bastien-Lepage. Nairn's non-illusionistic

\footnotetext{
37 The screen was found in Whistler's studio at the time of his death. See, Andrew McLaren Young et al, The Paintings of James McNeill Whistler, New Haven and London: Yale University Press, 1980, 85. 38 Glazer and Merrill, Palaces of Art, 10.

39 Casteras and Denney (eds.), The Grosvenor Gallery, 5.
} 
composition of flattened forms, vivid colours and strong definition of line are reminiscent of the French painter, Pierre Puvis de Chavannes. ${ }^{40}$

By 1880, Puvis had established a reputation for being one of the foremost French painters on the Continent. On 1 March 1888, Alexander Reid, a friend of Puvis and an admirer of his paintings, purchased Ludus Pro Patria, 1883 (Walters Art Museum, Baltimore). Reid sent his most recent purchase to Glasgow, where it was later displayed at the International Exhibition of 1888. Reid's foresight and the generosity of other prominent art collectors in England and Scotland allowed young artists situated in Glasgow to study contemporary art by some of the most revered painters of their generation. ${ }^{41}$ Other works to appear alongside Puvis's Ludus Pro Patria were Whistler's Portrait of the Artist's Mother, 1871 (Musée d'Orsay, Paris), Burne-Jones's The Tower of Brass, 1887-88 (Glasgow Museums, Glasgow), and Watts's Diana and Endymion, 1872 (private collection).

Although Nairn does not specifically mention Puvis as an influence, these early encounters with the art of modern painters in Glasgow certainly left an impression on his approach to painting. Nairn's flattened treatment of his four maidens on the screen are faithful to Puvis's 'less is more' approach - a concept which in turn inspired proponents of Aestheticism and Symbolism. There is almost an 'unfinished' quality to the figures and surrounding landscape and this is demonstrated in the panel representing 'Winter'. On the lower left side of the panel there is a hazy mist of smoke rising from the burning embers in the foreground. Nairn's broad brushstrokes of contrasting blue and orange tones engulf the hooded figure. His treatment implies that he did not paint what the viewer could already see, but chose to show nature in its most simplified form. This was an attitude also shared by Puvis, who stated 'the simplest conception proves to be the most beautiful. Painting isn't an imitation of reality, but [is] a parallelism of nature'. ${ }^{42}$ Nairn's 'Winter' stands upright with a vacant expression, her hands clasped. This pose is significant as it shares similarities to a figure standing in Puvis's Ludus Pro Patria.

\footnotetext{
40 Anne Kirker 'Special Feature, The Nairn Screen: A New Acquisition', National Art Gallery Newsletter, April-June 1988, 7.

41 The Scottish Art Review, 1, 9, February 1889, 243.

42 Brown-Price et al., Pierre Puvis de Chavannes, 15.
} 
The figures, across all four panels, are dressed in rigid folds of brightly coloured fabrics. Their bodies and garments are well defined by hard-edged outlines. Behind the figures, variations of sawn-off and oddly arranged cluster of trees are positioned in the seasonal landscape setting. The high horizon line filled with solid blocks of colour is a characteristic of Puvis's paintings. Nairn's screen shares not only aspects of Puvis's style but also communicates a feeling of beauty through a decorative yet functional object. When I observed the screen for the first time, it appeared as though the two opposing sides were disconnected. On closer inspection, the trees in the Japanese landscape interconnect and change with the seasons at the intersection of each panel. It then became apparent that the seasons on each side of the screen corresponded. The panels comprising the four maidens depict, from left to right, Spring, Summer, Autumn, and Winter. The panels featuring the Japanese scenes also display the versatile nature of the seasons but they read from right to left, as traditionally, Japanese is read vertically in columns and ordered from right to left. Despite the different subjects on opposing sides of the screen, Nairn has thought about the entire composition. He has created harmony between East and West by coordinating each panel with a tribute to the changing nature of seasons.

As a young painter, Nairn experienced the 'wonderful results, apparent on the European continent' and recalled seeing 'work in several different mediums for the people, in the form of decoration for museums, cathedrals, and other public buildings'. ${ }^{43}$ Once he had returned to Glasgow, Nairn, Alexander Roche, Peter MacGregor-Wilson, and Edward A. Hornel were entrusted with designing large mural paintings in the galleries for the Glasgow International Exhibition of 1888. Nairn and his peers were admired in The Scottish Art Review and Quiz for innovative designs that had never before been attempted in Scotland. ${ }^{44}$ Reviewers were fascinated by how the members of the Glasgow Art Club transported the sophisticated décor of 'Neo-Renaissance' mural design found in England and France to Scotland. The British artist Ford Madox Brown had recently completed his large mural in Manchester's Town Hall; Whistler had been invited to paint a celestial study of the moon and stars

\footnotetext{
43 James McLauchlan Nairn, 'Decorative Art,' 'Art and Artists' by James M. Nair [sic] (A Member of the Glasgow Art Club) Being a Paper Read Before the Students of the Otago School of Art', OW, 7 August $1890,41$.

${ }^{44}$ Fiat Justitia, 'Light and Shadows,' Quiz, 20 April 1888, 70. (Nairn, Scrapbook, Te Papa).
} 
on the ceiling of the Grosvenor Gallery in London; and the French artists Jules Bastien-Lepage and Pierre Puvis de Chavannes had both achieved success with their large paintings decorating municipal buildings on the Continent. ${ }^{45}$ Nairn would have encountered such works in the galleries of Europe, allowing him to communicate the knowledge he acquired with his 'brothers' in Glasgow and, subsequently, in New Zealand.

Nairn's obituarist asserted that during the artist's lifetime, he strongly rejected the idea of being remembered as an Impressionist painter. ${ }^{46}$ This statement prompted Pound to revisit McCormick's limited view of Nairn's place in New Zealand's art history. In his book Frames on the Land, Pound dedicates a section of his writing to Nairn. Pound's study on nineteenth-century landscape painting in New Zealand refers to Nairn's speech of 1892 entitled 'The Progress of Art in New Zealand'. Pound claimed this lecture to be the most important and comprehensive document of the artist's ideas. In this lecture, Nairn addressed the members of the Wellington Art Club:

If we want art, we must begin at the point where all great artists have begun: the study of nature from life or outside. All the great men have gone in for close study, as exemplified in the works of Constable, Corot, Lepage and Cecil Lawson, who stand at the top of the tree. ${ }^{47}$

This list of artists and, more notably, those not mentioned, surprised Pound. His close examination of this quote reveals that Nairn did not refer to the iconic artists of the Impressionist School. Instead, Nairn has chosen to admire 'Pre-Impressionists' from 'the English and French schools of landscapists' who, in the past, observed Nature through the eyes of a painter. One of founders of the landscape tradition and precursor to plein air painting, John Constable and his lesser-known Scottish 'disciple', Cecil Lawson (a successful artist towards the end of his life and gained posthumous recognition at his retrospective at the Grosvenor Gallery in 1883) are

\footnotetext{
45 The Scottish Art Review, 1, 10, March 1889, 304.

46 'Obituary', NZH, 23 February 1904, 5.

47 James McLauchlan Nairn, 'The Progress of Art in New Zealand', NZM, 6 October 1892, 11. First cited in Pound, Frames on the Land, 86. These artists are also mentioned in Nairn's, 'Some Notes on Landscape Painting', NZM, 23 April 1896, 13.
} 
overlooked in relation to their influence on the Glasgow Boys. ${ }^{48}$ Pound's reassessment of those that influenced Nairn suggests the artist was not solely interested in the Impressionist Movement but was evidently inspired by a wide range of 'modern' painters.

As many art historians have done before him, Pound momentarily paused; he blocked out definitive claims made about Nairn's contribution to New Zealand art and stepped back to analyse the words expressed by the artist himself. This act alone is admirable. Pound's open-minded approach to deciphering New Zealand's art history is one that art historians should emulate. However, Pound does not analyse the content of a 'lost' lecture which Nairn presented to the Dunedin School of Art in July 1890. Nairn's first lecture on New Zealand shores does not appear to have been closely examined and the most probable explanation for this oversight is that art historians did not have access to this lecture on 'Decorative Art'. ${ }^{49}$ My aim for the remainder of this chapter is to analyse Nairn's lecture of 1890, which clearly demonstrates his comprehensive understanding of Aestheticism and complements what he had set out to achieve with his highly 'decorative' Anglo-Japanese screen.

\section{'DECORATIVE ART’-THE LECTURE}

On 25 July 1890, Nairn, a visiting 'member of the Glasgow Art Club' delivered his first lecture in New Zealand to the students of the Otago School of Art. This took place only six months after a health condition had forced the artist's sudden departure from Scotland. The Otago Witness subsequently published a transcript of the lecture verbatim. Nairn's lecture did not discuss plein air painting. Instead, he endorsed the following key features of the Aesthetic Movement: the 'pictorial' and 'decorative' representation of art; the artist George Frederic Watts; the Grosvenor Gallery in London; the arduous study of antique traditions; the simplicity of Japanese art; and the artist-designer of the Arts and Crafts Movement, Walter Crane.

\footnotetext{
48 In Billcliffe's Pioneering Painters, Bastien-Lepage is referred to 29 times compared to Corot mentioned once and, Constable and Lawson are omitted from the key text on the Glasgow Boys. 49 Transcript of Nairn's 'Decorative Art' lecture featured in Hearnshaw's M. A. Thesis appendices. She does so without sufficiently analysing the content of the lecture and its implications in her main argument.
} 
In his opening remarks, Nairn elected to primarily address what he meant by the term 'decorative art'. Nairn does not mean 'decorative' in the sense of 'decorative' versus 'applied' art, but merely implies the term is used 'to impose this notion that a trained artist can take the "ordinariness" of nature and apply the rules of art, which he has obtained through extensive training, to make it beautiful'. ${ }^{50}$ Elizabeth Prettejohn reiterated this point in her book Art for Art's Sake, where she explained that the meaning of 'decorative' has often been misconstrued. According to Prettejohn, the definition of the term 'decorative' essentially means a work of art (or object) that compels an individual to feel a sense of completeness, both visually and spiritually. ${ }^{51}$

Nairn's interpretation of the aims of Aestheticism entailed taking these ideas on decorative art and making it more accessible to the public. The only way to accomplish this was through the willingness of an artist to succeed at his chosen art practice. ${ }^{52}$ To achieve the 'decorative tout ensemble', an artist needed to unify all aspects of his work, including colour, form and line. Nairn emphasised that only through dedication to their artistic training at the School of Art would students be able to achieve a 'pictorially decorative' work to a high standard.

In an attempt to express what he meant by the term 'pictorially decorative', Nairn asked the students to recall a work of 'grace' and 'beauty' that had previously been on display at the New Zealand and South Seas Exhibition (26 November 1889 - 3 May 1890). ${ }^{53}$ George Frederic Watts's The Head of Alfred, Lord Tennyson (Poet Laureate), 1863-4 (private collection), also referred to as the 'Bowman Tennyson', was discussed at length to provide an example of 'Decorative Art' [Plate 15].

Let me give as an example of really true art, a picture which will be a lasting memory to me, and, I hope, to all who saw it and studied it - viz., The Head of Tennyson in the Art Gallery at the Exhibition. ${ }^{54}$

\footnotetext{
50 Laura Campbell, 'James McLauchlan Nairn (1859-1904): Through an Aesthetic Lens', B. A. (Hons.) Thesis, unpublished, 2014, 13.

51 Prettejohn, Art for Art's Sake, 198.

52 Dianne Sachko Macleod, Art and the Victorian Middle Class: Money and the Making of Cultural Identity, Cambridge: Cambridge University Press, 1996, 272.

53 Two versions of the painting exist. Its' 'twin' dated 1873, is housed at the National Portrait Gallery, London. See Jeremy Maas, Victorian Painters, London: Barrie \& Jenkins, 1969, 201.

54 Nairn, 'Decorative Art', 41.
} 
Nairn elected to focus on Watts's portrait, as it was in his opinion, the most successful 'pictorially decorative' painting at the exhibition. His decision to analyse Watts's painting was an intriguing selection for the artist to make. For example, hanging in Gallery IV was a painting by one of the founding members of the New English Art Club and Newlyn School painter, Stanhope Alexander Forbes (1857-1947). Surely, if Nairn was to admire a 'decorative' work following the plein-air tradition of BastienLepage, then he would have analysed Forbes's Preparations for Market, Quimperlé, Brittany, 1883 (Dunedin Public Art Gallery). This certainly would have been a more obvious choice. Why then, did Nairn select this particular work by Watts for such careful analysis? After all, Watts was not considered a plein-air painter. The Royal Academician was admired as a leading portraitist, history painter and contributor to the Aesthetic Movement in Victorian England. During the English artist's lifetime, he spoke freely about his support for the ideals that we now associate with the Aesthetic Movement-the study of the antique, simplicity of Japanese design, the decorative effects of the painted surface, and celebrating Artfor Art's Sake.

Nairn had clearly encountered Watts's work first-hand while exploring the New Zealand and South Seas Exhibition, in Dunedin, with the art dealer, Wright.55 In his lecture, Nairn claimed the 'Bowman Tennyson' had left him feeling mesmerised. 56 So, what was it about Watts's painting that captivated Nairn? The portrait depicts a 'bustlike' study of the Poet Laureate, Alfred Tennyson. Watts befriended the renowned poet and requested to paint him on more than one occasion. ${ }^{57}$ He painted two versions of Tennyson side-by-side during a third sitting with the Poet Laureate; the first was purchased by the revered ophthalmologist, Sir William Bowman and the second was kept by the artist himself, later bequeathed to the National Portrait Gallery, London in $1895.5^{58}$ There are other examples of Watts's portraits of Tennyson

\footnotetext{
55 'All Sorts of People', FL, 5 March 1904, 3.

56 The Alfred Tennyson exhibited at the Dunedin Exhibition was owned by Sir William Bowman (Bart.). Ownership confirmed in insurance records, published in 'Exhibition News', OW, 26 September 1889,

13. The 'Bowman Tennyson' was subsequently sold at Christie's auction-house on 25 March 1994, lot 73 and is currently in a private collection.

57 Another portrait by Watts of Tennyson was exhibited at the Grosvenor Gallery Intercolonial Exhibition in Melbourne (1887-88) and purchased in 1888 for the National Gallery of Victoria collection. See John Payne, Framing the Nineteenth Century: Picture Frames 1837-1935, Peleus Press and NGV, 2007, 143.

58 'Twin' portrait of Watts's Alfred Tennyson, 1st Baron Tennyson, c. 1863-64, (London: National Portrait Gallery).
} 
which position the sitter in three-quarter pose, dressed in his red scholarly robes or peerage regalia. Bowman's Tennyson shows a more intimate perception of the scholar. Watts elected to portray his close friend without the discernible signs of his status and intellect. This instilled a considerable sense of vulnerability on the sitter, who at first glance would not immediately be identified as one of the greatest poets of his age. Instead, Watts placed Tennyson in a frontal pose. His dark complexion, brown hair and beard present a 'youthful' looking man wearing a more subdued black cloak with a white collar. The 'Bowman Tennyson' confirms Charles Baudelaire's assertion that only a gr eat colourist can extract 'colour from a black coat, a white shirt, against a dark background'.59

The poet appears motionless yet imparts a presence due to his incredible 'likeness' when compared to the real man. The upper half of the composition bathes the head of Tennyson in a warm light. He is crowned by a wreath of Bay laurel leaves. A restrained palette of green, blue and flickers of yellow creates a mysterious seascape in the background. The English writer G. K. Chesterton admired this section of the composition for 'the mere materialising of the poet's own spirit in the eternal laurels and the eternal seas'. 60 To breathe life into a portrait through capturing 'the artist's mind in colour' is an incredible feat and one that was greatly admired by Nairn. ${ }^{61}$

At the New Zealand and South Seas Exhibition, Watts's painting was arranged on a feature wall surrounded by several other examples of his work. Above the 'Bowman Tennyson' was Watts's large allegorical work, The Spirit of Christianity. The small selection of Watts's paintings were unified by matching bronze-gilded frames. Nairn chose to disregard the other paintings in his discussion and focus on the portrait. His favourable response to the work might be connected to the portrait's careful placement in the gallery space. The Head of Tennyson was placed at eye-level, to create intensity between viewer and subject. When standing in front of the portrait, Nairn felt as though he was in the presence of two great men-Tennyson, a revered

\footnotetext{
59 Elizabeth Pennell and Joseph Pennell, The Life of James McNeill Whistler, London: W. Heinemann, 1908, 217.

60 G. K. Chesterton, 'The Literary Portraits of G. F. Watts, R. A.', The Bookman, XIX, 1900, 81. Cited: Mark Bills and Barbara Bryant, G.F. Watts Victorian Visionary: Highlights From the Watts Gallery Collection, New Haven and London: Yale University Press, 2008, 36, 49.

61 Nairn, 'Decorative Art', 41.
} 
intellectual, and Watts, a true master of art. Nairn's emotive response to the painting was shared by the portrait's owner, Sir William Bowman. His reception of the portrait in the privacy of his own home was that 'painter and painted' would feel like 'a pair of nobles answering one to the other on my walls'. ${ }^{62}$ The spiritual intensity of Watts's painting, as expressed by Bowman, was also felt by Nairn when he stood in front of it at the Exhibition in Dunedin.

The spellbinding effect that Watts's Alfred Tennyson exerted over Nairn was reinforced by Dunedin critic Malcolm Ross's compelling analysis of the painting: 'His [Watts's] portraits stand alone; they are not the picture of the outward man only, but of the inward spirit.' 63 Nairn's lecture also discussed this 'sixth sense', which only the 'true disciples of art' were fortunate enough to possess. ${ }^{64}$ This rare gift was raised in Mark Bills and Barbara Bryant's extensive research on Victorian art. They propose the precision of Watts's brush and refined colour palette in this painting led to a somewhat 'hypnotic' experience for the viewer. ${ }^{65}$ Nairn explained:

There was life in the head, and out of the eyes beamed the soul of the great poet. There was no feeling of paint, or searching after paltry detail in the work, but it was the outcome of a great man's mind in colour, presenting a perfect poem in itself-in fact, a masterpiece of art-pictorially, yet decorative, and from its rightness came its pictorial beauty. ${ }^{66}$

Watts's ability to express his vision of the poet's facial features through the medium of oil paint was extraordinary. His accuracy in painting the folds of skin under the eye and the fine individual strands of hair resulted in a startling resemblance to the poet. He certainly accomplished this with the 'Bowman Tennyson' and its variant copy housed in the National Portrait Gallery (London) collection. In this excerpt from Nairn's lecture it is quite extraordinary to sense his admiration for Watts's fastidious application of colour onto the surface. Instead of promoting the layering of visible

\footnotetext{
62 Mary Seton Watts, George Frederic Watts: The Annals ofan Artist's Life, 1, London, 1912, 217-18. Cited: Bills and Bryant, G.F. Watts Victorian Visionary, 36.

$63 \mathrm{Mal}$ colm Ross frequently signed his initials M. R. for his criticisms of the exhibition. He was a reviewer for the Otago Daily Times and exhibitor at the Otago Art Society in the 1890s. See profile in Una Platts, Nineteenth-Century New Zealand Artists: A Guide and Handbook, Christchurch: Avon Fine Prints, 1980, 290; Ross, 'Some of the Exhibits', ODT, 3 December 1889, 5.

64 Nairn, 'Decorative Art', 41.

65 Bills and Bryant, G. F. Watts Victorian Visionary, 36.

66 Nairn, 'Decorative Art', 41.
} 
daubs of thick impasto, the artist appreciated Watts's lyrical method in applying oils on to the canvas.

In 'Decorative Art', Nairn makes a revealing comment about the poet-painter's ability to unify art, poetry and music. This link made between the disciplines was a key aspect of the Aesthetic Movement in England. As Walter Pater, one of the founders of Aestheticism, preached, 'All art constantly aspires towards the condition of music' ${ }^{67}$ Obviously familiar with Pater's words, Nairn stated that, in order for artists to achieve 'a new reading of Nature ... the works of the great masters require study, too, where the true soul and love of music is desired'. ${ }^{68}$ It was the role of the artist to experiment and somehow capture their unique perception of Nature in a way that the 'ordinary pot-boiler' could never envision in the real world. This idea of encouraging artists in all disciplines to elevate the status of art to its purest form was also recommended by Whistler in his Ten O'Clock Lecture presented in 1885:

Nature contains the elements, in colour and form, of all pictures, as the keyboard contains the notes of all music. But the artist is born to pick, and choose, and group with science, these elements that may be beautiful-as the musician gathers his notes, and forms his chords, until he brings forth from chaos glorious harmony. To say to the painter, that Nature is to be taken as she is, is to say to the player, that he may sit on the piano. That nature is always right, is an assertion, artistically, as untrue, as it is one whose truth is universally taken for granted. Nature is very rarely right, to such an extent even, that it might almost be said that Nature is usually wrong: that is to say, the condition of things that shall bring about the perfection of harmony worthy a picture is rare, and not common at all. ${ }^{69}$

In this speech, Whistler insisted on distancing art from morality and from Naturalism. Music was the purest art discipline and Whistler adopted key words such as Harmony and Symphony to name his paintings. This act alone informed the audience of his new 'theory in art'..$^{70}$ Whistler identified the abstract language of music engrossed an audience and made them fall into a sense of synaesthesia. This total immersion was

\footnotetext{
67 Pater, The Renaissance, 106.

68 Nairn, 'Decorative Art', 41.

69 James McNeill Whistler, 'Ten O'Clock Lecture, presented in London 20 February 1885. Cited: 'The Correspondence of J. M. Whistler'. http://www.whistler.arts.gla.ac.uk/miscellany/tenoclock/. Accessed: 2 October 2015.

70 Andrew McLaren Young, Margaret MacDonald, Robin Spencer, and Paul Mellon Centre for Studies in British Art, The Paintings of James McNeill Whistler, New Haven: Yale University Press, 1980, 84.
} 
achieved in the paintings of English Aesthetes and explains the sensations Nairn described when standing in front of Watts's masterpiece of 'poetical beauty'.

Nairn followed on from his recollection of the portrait to explain the current situation plaguing art in Britain and his admiration for men who were the real 'backbone' to producing 'good' art. Britain was an industrial centre of innovation and beacon of commercial culture. Despite societal changes, political restructuring and economic growth, Nairn expressed his disappointment at the declining standards of art. He compared art to music and claimed the foundations of both disciplines were built on tradition. Due to the advancements made in technology 'the artist' had been sidelined by 'imitators', thereby corrupting the autonomy of art. The reputability of art and music were threatened by the 'easy-going man' who believed it was his duty to produce second-rate copies of 'abominations at 5 s a foot, which have neither colour, drawing, nor anything, and resembling nothing on earth or sea'. ${ }^{71}$ This statement was professed by the thirty-one year old artist who, only six months earlier, had departed from an increasingly unsettled and divisive art environment in Glasgow. Nairn raised his concerns about the 'trivial prettiness' of pictures with the students of Dunedin. In his lecture, he reiterated that art should not be produced to satisfy the demands of 'ordinary men'. The autonomy of art needed to be resurrected by the artist. According to Nairn, only a true servant of art, such as Watts, would understand that art should be made for pleasure not production.

In art the ardent student comes forward, and through his sincerity and love of Art for Art's Sake, presents to the world his own, and a new reading of Nature, which is really, from its originality, great. ${ }^{72}$

Nairn relayed the artist's ability to embrace art for its own sake would 'in all probability end in failure, and by such failure will come success gradually; and a proper tendency to the appreciation of good art will be arrived at by practice'. ${ }^{73}$ His uplifting words professed that it was the responsibility of young artists to uphold the true meaning of art and paint for its own sake. Despite these words of encouragement, Nairn warned the students that not everyone is born with a gift as

\footnotetext{
${ }^{71}$ Nairn, 'Decorative Art', 41.

72 Ibid.

73 Ibid.
} 
great as Watts. This is reaffirmed by his opening statement: 'I should like so much to be able to paint'; a generic phrase often overheard in art galleries. To improve the standards of art in New Zealand, Nairn believed these students needed to persist with their training and stay true to the origins of Aestheticism: or that is, to promote Art for Art's Sake. Nairn understood that failure inevitably accompanied progress. Over a period of time proper training would result in the next generation of artists in New Zealand elevating standards of art. This would benefit artists and the general public in discovering an appreciation for art in this country.

As a young artist practising in Glasgow, Nairn had been exposed to the politics of art. Standing before the students in Dunedin, Nairn made an astonishing comment about the failures of the Royal Academies of England and Scotland. He expressed his dissatisfaction with the standards set by these once prestigious art establishments. He believed the Academies were failing in their duty to train the next generation of artists to a satisfactory standard:

Those institutions have closed their doors to the advances of art with the rising generation, but keep sailing over the calm sea of fashionable picture making. Young spirit and power has been kept out, rejected, or when admitted, skied. Why? Because true to themselves, the young men would not for art's sake follow in the steps of men whom they sincerely thought were not true, either to themselves or art. ${ }^{74}$

Strict rules enforced by the Royal Academy resulted in the exclusion of a large number of promising artists, many of whom were rebuffed for their differentiating thoughts on how to paint and were therefore deemed too radical. Nairn considered senior officials to be ignorant in their refusal to admit talented individuals into the increasingly exclusive membership of the Royal Academies. Their hindrance on progress was seen as an enormous loss for 'art and her mission'. In response to this threat to the autonomy of art and its maker, independent art institutions began to emerge in England and Scotland. The Royal Academies' control over the artist was challenged by the creation of independent galleries. Nairn's lecture praised the founding members of the Grosvenor and English Art Club Galleries for their support of artists. These institutions were not seen as equivalents of the Salon des Refusés in

\footnotetext{
74 Nairn, 'Decorative Art', 41.
} 
Paris, but were regarded as a self-regulating forum where artists could actively 'step forward and do something for our own benefit at present and from the present'. ${ }^{75}$

After witnessing the poor treatment of talented individuals by the Scottish Royal Academy, Nairn applauded the unconventional approach undertaken by bohemian artists, who opposed such powerful yet repressive authorities on art education in Britain. He stated:

In the Grosvenor and English Art Club Galleries are seen works from the young and energetic men who have gone through a thorough training in drawing and severe study, resulting in fine art productions visible in the pictures of those men, which can be termed a pervading sense of the true artloving soul. ${ }^{76}$

Remembering that Nairn presented his lecture in July 1890, this statement could be referring to the recent achievements made by his 'brother' artists in Glasgow. In early 1890 Sir Coutts Lindsay engaged in discussions with 'The Boys' offering them space to create their first group show in what was to be the final Grosvenor Gallery Exhibition. The financial woes of Lindsay meant his beloved 'Palace of Art' would be forced to close its doors in December $1890 .{ }^{77}$ The Boys' refreshing and innovative approach to painting was very well received by art critics and the general public in London. Art historian Victoria Hearnshaw has even suggested that, if Nairn had not departed for New Zealand in September 1889, there was a strong possibility that his pictures would have featured alongside his 'brothers' at the Grosvenor, in May $1890 .^{78}$ This argument is strengthened by a conversation that took place when a friend of Nairn's, Charles Wilson, visited the Glasgow Art Club in 1903. He mentioned Nairn to an elderly gentleman at the gallery who remembered 'that clever Nairn lad' and expressed, 'Aye, but he would ha' made a gran' name for himself had he stopped in Glasgow'. ${ }^{79}$ Nairn's contribution to the Art Club was reinforced further by another anecdote, this time concerning a young New Zealand artist who 'went home to study art' and was asked: 'What do you want to come here for, when you have the best

\footnotetext{
75 Nairn, 'Decorative Art', 41.

76 Ibid.

77 Casteras, The Grosvenor Gallery, 7.

78 Hearnshaw, 'James McLauchlan Nairn', 61.

${ }^{79}$ Charles Wilson, 'James McLachlan Nairn', Sydney: Art in Australia, 5, August 1923, unpaginated.
} 
possible man in J. M. Nairn. Go back to him' ${ }^{80}$ These praiseworthy recollections of Nairn back home, made nearly a decade after his departure, reaffirm that by 1889 he was making progress as an established member of the Glasgow Art Club.

David Con Hutton recognised Nairn's talent upon his arrival in Dunedin and invited him to discuss his artistic philosophy at his home. According to the Drawing Master's son, David Edward Hutton (1866-1946), his father also invited W. M. Hodgkins (President of the Otago Art Society), George Bell (Editor of The Star), Professor J. H. Scott, Mr J. White, R. F. Smith, George Joachim, and the Dunedin artist Alfred O'Keeffe to attend. ${ }^{81}$ As promised, Nairn brought his portfolio of sketches completed while on board the Forfarshire and spread the sketches across the table after dinner. Hutton was delighted with Nairn's 'masterly treatment' and the 'beautifully silvery line' in his oil and charcoal sketches. ${ }^{82}$

After discussions with senior artists and patrons in Dunedin on the diminishing state of New Zealand art, Nairn believed there was an urgent need to form new Art Clubs in this country. The lecture outlined Nairn's perception of the dysfunctional 'possession is nine points of the law' system enforced by the Royal Academies of Scotland and England. Untainted by this bureaucratic and 'toxic' environment, he believed there was potential for artists in New Zealand to elevate the standard of art. Nairn asked the students of Dunedin to emulate:

Those single-hearted and strenuous efforts of our younger men [which] are undoubtedly marked by advance, and one would be only too pleased to see this energy among yourselves, and you're quite sure of success when you work hard. 83

The artist's endorsement for the creation of Art Clubs had a resounding effect on those present at the lecture; 'stimulating the students into action'. ${ }^{84}$ The following year, in 1891, the Dunedin School of Art Club was established. Nairn supported the founding of this Art Club and in October 1893, sent three paintings of his own for

\footnotetext{
80 Murray-Oliver, 'James McLachlan Nairn', 2.

81 Typewritten note found on the reverse of Guy Morris's photograph of J. M. Nairn and G. P. Nerli, 1896 (Dunedin: Hocken, Box-171 MOR076,).

82 M. E. R. Tripe, 'James McLauchlan Nairn: Some Personal Reminiscences', Art in New Zealand, 1, December 1928, 105, and Murray-Oliver, 'Brief Notes', 2. (Wellington: ATL, qMS-1402).

83 Nairn, 'Decorative Art', 41.

84 'Dunedin School of Art Club’s Exhibition', ODT, 7 September 1891, 3.
} 
display at the annual exhibition. Senior artists involved with the Dunedin School of Art Club showed their indebtedness to Nairn:

A young and enthusiastic artist from Glasgow, who was on tour through the colony last year, visited the Dunedin School of Art and delivered an address to the students on "Art and the Brotherhood" in which he strongly urged on them the importance and the many advantages to be derived from art clubs. ${ }^{85}$

While recognising the progress made in art by young professional artists in Europe, Nairn's speech reminded the students of Dunedin, and later in Wellington, to always remember the necessity of first learning how to draw:

By the arduous study of the antique and life, one gets a knowledge of fine form and line, and of light and shade. This knowledge gained and applied properly must have the result desired by the art-loving student. ${ }^{86}$

Those attending the lecture were instructed to never lose sight of drawing from the antique and mastering the effects given to us in Nature through light, form and shade.

The students attending Nairn's life drawing classes at the Wellington School of Design recounted his words: 'Mind your drawing' was his constant injunction, 'for good drawing is the foundation of true art.' 87 Nairn exemplified these methods in his own work and they are reflected in a photograph showing Nairn working in his studio during the late 1890s [Plate 16]. He poses with his brush and palette in front of a portrait at his easel. Behind his easel, fabrics are lavishly draped between small paintings which hang on the studio walls. Positioned to the right of the photograph, Nairn analyses the marble statue, Venus de Milo. This iconic statue epitomises the grace, beauty and harmony found in Classical art. Alison Smith perceives the constant presence of Venus in the artist's studio to be a metaphor for an 'artistic rebirth': a desire formed in Pater's Aesthetic renaissance in England. ${ }^{88}$ Nevertheless, Nairn believed it was only through hours of examining the antique and life model that an artist could truly begin to gain sufficient knowledge of the human form.

\footnotetext{
85 Ibid.

86 Ibid.

87 Wilson, 'James McLachlan Nairn', unpaginated.

88 Smith, The Victorian Nude, 114-16. Cited: Morna O'Neill, Walter Crane: the Arts and Crafts, Painting, and Politics, 1875-1890, New Haven: Yale University Press, 2010, 35.
} 
One of Nairn's pupils, who attended art classes in Wellington in the 1890s, noted that his teacher was the first artist in New Zealand to introduce life classes to study the nude. ${ }^{89} \mathrm{~A}$ series of archival photographs capture Nairn teaching art classes at the Wellington Technical School [Plate 17]. These amateur photographs reveal Nairn's enduring belief in the importance of conventional art practices, which was instilled in him as a student in Glasgow and Paris. In a lesson on drapery in 1904 (only a few months before his untimely death), Nairn is captured sitting unobtrusively behind the model. She wears delicate folds of drapery and stands side-on.

An emphasis on the importance of drawing from the antique was already well established in the art curriculums of several New Zealand art schools. In 1869, David Con Hutton (1843-1910) was appointed the first 'Drawing Master' at the Dunedin School of Art. There was great anticipation surrounding Hutton's arrival in Dunedin from Perth on 19 January 1870. Crowds gathered, not to meet the professional artist but for a chance to inspect his cargo. The Christian McAusland was carrying Hutton's collection of antique casts sourced directly from the studio of the celebrated modeller at the Kensington School of Design, Domenico Brucciani. ${ }^{90}$ Hutton's antique sculptures are documented in one of the finest surviving representations of an art school in New Zealand; a painting completed only a few months after Nairn had been invited to speak there.

James Kilgour, an amateur student who attended Nairn's lecture, painted Dunedin School of Art, c. 1891 (Hocken Library, Dunedin) [Plate 18]. In the centre of the room Hutton stands at his easel surrounded by his beloved plaster casts highlighted against rich-coloured crimson walls. On the right, a female student sits at her easel. She examines the defined musculature of an antique cast, the Borghese Gladiator. It was standard practice for a female artist to learn how to draw human anatomy from the antique, as sketching from a life model was frowned upon. What is most asto unding about this rare glimpse into a New Zealand art school is Kilgour's inclusion of an oriental screen and decorative Chinese vase. In the right foreground a rich fabric flows out of the vessel and across the floorboards. Perhaps Kilgour included the

\footnotetext{
${ }^{89}$ Murray-Oliver's claim was challenged in a newspaper article stating: 'Classes from the life were conducted at Mr W. L. Morison's School of Art in the Exchange Buildings before Mr. Nairn arrived in the colony'. See 'Advertisements', EP, 24 February 1904, 4 and Murray-Oliver, 'Brief Notes', 4. 90 'Models for the Drawing School,' ODT, 12 February 1870, 2.
} 
oriental vase and fabric after listening to Nairn proclaim the art of Japan was a gift to the artistic world. ${ }^{91}$ Nairn encouraged students to observe art from the Far East and confessed, 'Herein lies their greatness, admitted by the artistic world. All the work is decorative, and still has a strain of realism which, by its consideration for colour, values and tone, makes the work fine in an artistically decorative sense'. ${ }^{92}$ Kilgour's painting could therefore be an embodiment of Aesthetic tendencies proposed in Nairn's lecture.

Nairn continued to distance himself from the 'conventional' school, in this case the New Zealand Academy of Fine Arts, and instead established an Art Club in the New Zealand capital, Wellington. Tony Eden has proposed that Nairn's decision to create the Wellington Art Club (founded 1892) was not a complete rejection of the Academy and its 'depressed' environment, but was more realistically driven by local artists requesting art classes. Nairn was given permission to teach a class once a month at the Academy. ${ }^{93}$

The Wellington Art Club held annual exhibitions and acted as an independent forum for local artists, including Mabel Hill and Mary Elizabeth Tripe (née Richardson). The Art Club became a social arena, where enlightened conversation would echo around the gallery spaces. Nairn's 'Aesthetic flair' was implied from the outset as elaborately designed invitations for the 1893 annual exhibition were sent to artists and the social elite in Wellington. An invitation sent to Will and Isabel Field (brother-in-law and sister of Frances Hodgkins) illustrates an artist wearing a suit with dishevelled hair, standing holding a brush and palette [Plate 19]. His back is turned to the viewer, as he paints directly on to a large canvas. In the top left corner, Nairn uses the initials of the Art Club 'W. A. C.' to create a stylised monogram. Small additions in watercolour were individually hand painted onto each invitation. This is an Aesthetic touch: a signal to his guests that this exhibition would be very different to those held in the past. On the Fields' invitation, there is a silhouette of a sunflower rising out of a Japanese vase, and on Mabel Hill's invitation, there is an image of bamboo [Plate 20]. The sunflower, bamboo and Japanese object refers to the Art Club's pledge to uphold

\footnotetext{
91 Ibid.

92 Nairn, 'Decorative Art', 41.

93 Robin Kay and Tony Eden, Portrait of a Century: the History of the NZ Academy of Fine Arts, Wellington: Millwood Press, 1983, 41.
} 
'Art for Art's Sake'. The invitations were seamlessly integrated into the exhibition concept and prepared the invitee for the beautiful gallery environment they were about to encounter.

In 'Decorative Art', Nairn emphasised it was the artist's responsibility to elevate the expectations and standards of art education. As President of the Wellington Art Club (1892-1896), Nairn expressed his intent to enrich the minds of the ordinary public with 'true artistic art' and beautiful surroundings at their annual exhibitions. An Aesthetic design evoking a sense of pleasure was proposed for styling the interior at the Wellington Art Club exhibitions of 1893 and 1894. Nairn's cover design for the second annual exhibition catalogue is reminiscent of the 9 by 5 Exhibition catalogue designed by Charles Conder in Australia [Plate 21] ${ }^{94}$ As discussed in Chapter One, the 9 by 5 Exhibition was a celebration of national art in an Aesthetic mode of display by our Australian counterparts, and arguably, so, too, was Nairn's carefully orchestrated exhibition.

Aspects of Aestheticism are prevalent in Nairn's cover design [Plate 22]. A serpentine-shaped climbing plant and flowers form a border around the monogram and red ink lettering. A bohemian artist with long hair stands in front of a large canvas with his palette and brush. Nairn's contribution to the catalogue's cover design demonstrates that every minute detail of the exhibition was stage-managed, especially the exhibition layout. Lord Glasgow opened the exhibition and his speech was followed by a tea service and the accompaniment of music soon filled the gallery. ${ }^{95}$ One individual wrote that the décor of 'the gallery has been very tastefully arranged with palms and pot plants from Government House, and old gold draperies, which have been freely used over and around the frames, and are admirably harmonious and effective. The glaring yellow labels which mark the bottom of each section are the only chromatic discord in the general effect'. ${ }^{96}$ The exhibition's harmonious colour scheme of blue, green and yellow was complemented further by Nairn's Whistlerian Motif-Blue and Yellow. In one of the few surviving photographs, Mabel Hill, a pupil of Nairn is also clearly familiar with the Whistlerian Aesthetic

\footnotetext{
94 Creator of cover design for the Art Club's catalogue is identified in 'Yesterday's Proceedings', Evening Post [EP], 28 June 1894, 2.

95 'A Lady's Letter', Manawatu Herald, 19 July 1894, 3.

96 'Wellington Art Club, Second Annual Exhibition,' EP, 16 July 1894, 4.
} 
profile and has painted her teacher accordingly [Plate 23]. A few years later, she posed for the photographer Francis Lawrence Jones in the same manner. ${ }^{97}$

The walls of the Wellington Art Club second annual exhibition (1894) are covered in portraits, still life and landscapes—not Aesthetic scenes of mythological goddesses found in the art galleries of England. However, there are components borrowed from Aestheticism which demonstrated how Nairn strived to create a gallery environment of harmony and pleasure. When planning the layout of an interior, whether private or public, Nairn shared:

To have a nice piece of fresh landscape on the walls at home is all very well, but what if the said pictures are not in tone with the room, and, what's worse, out of tone in themselves? Where pictures, not decorative, are shown which disturb the general surrounding art beauties, there is something wrong. Why so? Because anything which disturbs the mind or eye is either wrong in itself or the accessories. ${ }^{98}$

Nairn had the final say on how to decorate the gallery space and chose to make the gallery seem less formal. The layering of decadent fabrics around the paintings and placing fernery throughout the room made the space feel more domestic. The PhD research by Rebecca Rice explains the evolving nature of exhibition display during this period. She concludes that once-formal spaces were transformed into an atmosphere more akin to the privacy found in a collector's home or a cigar lounge. ${ }^{99}$

Nairn's 'unconventional eye' for decorating spaces was not isolated to art gallery interiors, or for that matter, the painting of the ship's cabin. To the dismay of his landlord, the artist took a paint-pot to the walls of his temporary residence and was subsequently billed for 'damages'.100 The Director of the Wellington School of Design, Arthur D. Riley described his admiration for the artist's 'decorative' paintings:

He knew that in many houses in New Zealand one's eye was caught on the walls with a spot of light like a gleam as from a precious jewel, and there was

\footnotetext{
97 Photograph by Francis Lawrence Jones of Mabel MacIndoe, c. 1898 (Wellington: ATL, Ref. 1/2092954-F).

98 Nairn, 'Decorative Art', 41.

99 Rice, 'The State Collections of Colonial New Zealand Art', 172.

100 'All Sorts of People', FL, 5 March 1904, 3.
} 
no need to go near and read the signature of J. M. Nairn to recognise whose work it was. ${ }^{101}$

The bohemian's impulse to paint with vibrant colours on canvas and the walls of his temporary living quarters are explained somewhat in the lecture:

The decorative beauty of a house is often absent on the walls thereof, because a tenant enters his new abode as the landlord let it-viz., three coats of paint by the contractors, without ever a thought whether the general result was or might be the least bit artistic or decorative. Here is the opportunity people have to make homes agreeable; but how few think of the artistic side of one's mind! 102

Nairn constantly strove to create spaces of heightened beauty, even if his eccentricity and 'decorative' additions to the room were not appreciated by some individuals. Although often ridiculed for his artistic gestures, he noted 'advance is made daily by a few artistic painters, who look upon a room as a picture of health and comfort; and this is due to art principles being their aim'.103 The desire for an artist to surround themselves with beautiful scenes can be better explained by Morna O'Neill's comparison between Whistler and Crane's 'use value' of decorative art: 'Whistler and Crane presented parallel modes of decorative painting that address the 'use value' of art in different ways; whereas Whistler acknowledged the purpose of painting as decorative, Crane put forth the implicit argument that the purpose of decoration was to uplift and inspire'.104

\section{WALTER CRANE-ADVANCING STANDARDS IN PUBLIC ART AND DOMESTICITY}

In the closing statements of his speech, Nairn does not refer to Whistler, but recites a quote from the socialist writings of Walter Crane, an artist-designer of the Aesthetic and Arts and Crafts Movements. In July 1888, Crane delivered a lecture to an audience, including Oscar Wilde, in London. He claimed the commercialisation of

\footnotetext{
101 'The Late Mr Nairn', EP, 26 February 1904, 5. Reprinted in New Zealand Illustrated Magazine (NZIM), 1 May 1904, 135-38.

102 Nairn, 'Decorative Art', 41.

103 Ibid.

104 Morna O'Neill, Walter Crane: the Arts and Crafts, Painting, and Politics, 1875-1890, New Haven: Yale University Press, 2010, 74.
} 
British art and society was a threat to the autonomy of art and its maker. He explained:

While we crowd our galleries and exhibitions with masses of pictures every year, our public halls and the walls of schools are left blank for the most part ...Why should not the walls of our schools be pictured with the drama of history? ${ }^{105}$

In relation to art education, Nairn used the following quotation to communicate Crane's concerns to a New Zealand audience. All too often 'we are thinking more of our shop windows than the windows of our minds'. ${ }^{106}$ In front of the art-loving public in Dunedin, perhaps Nairn is reiterating Crane's point by drawing attention to the problems he encountered at the New Zealand and South Seas exhibition and the potential ramifications it held for the standards of art in this country.

Nairn may have reached this conclusion after witnessing what he described as a panAsian assortment of 'knick knacks' at the New Zealand and South Seas Exhibition. At the centre of the Avenue of All Nations there was an astonishing exhibit of oriental objects. Messrs E. C. Reynolds and Co. were renowned for importing specialised goods and curios from the 'Museum of Arts and Manufacturers, Ko be-Hiogo' located in Japan [Plate 24]. The display was recorded as one of the most captivating sights at the New Zealand and South Seas Exhibition and a local journalist described the stall as follows:

Messrs E. C. Reynolds and Co have a very attractively arranged display in the Avenue of All Nations, in a space which is canopied by a bewildering array of Japanese lamps and entered through an opening that has been left in a light and elegant bamboo railing. It may be said that included in the display are some fine specimens of chinaware, bronzes, lacquerware, cabinet-ware, basket-ware, a great profusion of fans, walking sticks, folding scree ns, umbrella stands, and a general assortment of drawing room and mantel ornaments of unique designs. 107

105 The Scottish Art Review, 1, 4, February 1888, 82.

106 Original quote from Walter Crane, 'The Prospects of Art under Socialism' presented July 1888.

Transcript of lecture reprinted in The Scottish Art Review, 1, 4, September 1888, 82.

107 T. M. Hocken, 'Scrapbook of New Zealand and South Seas Exhibition' (Dunedin: Hocken, MS-

0451/038). 
The visitors were enthralled by the canopy of Japanese lamps hanging from the ceiling and the fretwork-filled spandrel (arch) of symmetrical designs - a detail synonymous with a Western-inspired Meiji innovation in Japanese architecture. ${ }^{108}$ It is fair to say Nairn was underwhelmed to see its inclusion. Earlier in the lecture, he discussed the prestige of Japanese art, but confessed there was an exception: 'I don't of course refer to the manufactured rubbish so commonly displayed as Japanese, with fashion as its patron'. ${ }^{109}$ The artist was aware of the mass influx of 'cheap', 'fashionable' objects entering Scotland, and now realised they had already reached the British colonies of Australia and New Zealand.

In the 1890s, Dunedin was the wealthiest town in New Zealand, due largely to exports in dairy, forestry and the discovery of gold. According to P. J. Gibbons, 'the tolerance, worldliness and sophistication of the haute bourgeoisie [in Dunedin] set them apartfrom the rest of colonial society. They were, in the colonial context, cosmopolitan people, often well-travelled and wealthy'.110 Unsurprisingly, the social elite of Dunedin inherited the collecting habits of those back 'home'. For example, the wealthy Jewish importer of grand pianos, David Edward Theomin, imported Liberty silks to drape across the ceiling of his pavilion [Plate 25].111 Theomin travelled extensively, first departing Dunedin for overseas in 1892. He travelled to Australia, Asia, America, Europe, and the Middle East to source 'exotic' objects for his home 'Olveston'. He returned with items such as weaponry, Persian bowls and MiddleEastern coffee-tables. Further items of exquisite embroideries were collected by Dorothy and Maria Theomin from India, Morocco, Turkey, and Central Asia. On the completion of the house in 1906, the Theomins entertained their closest friends in rooms designed with these objects from Japan and the Middle East.112 The opulence of Olveston's interior and other neighbouring properties on Royal Terrace, for example, David Scott's 'decorative' glass panels at George Esther's 'Te Tarata' [Plate

\footnotetext{
108 I am indebted to Richard Bullen, Senior Lecturer, Art History and Theory at Canterbury University, Christchurch. Bullen believed the photograph shows a filled fretwork, and this kind of design in Japan is ordinarily found in the rectangular space between the lintel and the ceiling of a room, often called a 'ramma'. Correspondence received 3 November 2015.

109 Nairn, 'Decorative Art', 41.

110 P. J. Gibbons, 'The Climate of Opinion', in W. Oliver (ed.), The Oxford History of New Zealand, Wellington: Oxford University Press, 1981, 311.

111 Unidentified news clipping (Dunedin: Hocken, Scrapbook, MS-0451/038).

112 'Table Talk', OW, 4 September 1907, 71. Cited: Blackman, Dorothy Theomin of Olveston, 21.
} 
26] displayed the owner's 'worldliness', wealth and urge to acquire beautiful objects; a welcome distraction from his sometimes all too consuming and stressful business affairs. ${ }^{113}$

In the lecture, Nairn acknowledged the role of creating 'decorative art' was to momentarily distract the weary businessman from his 'daily monotonies':

In every country there is art born in the people and to develop this sense let us study not merely to become workers in, but workers for art. New Zealand is a rising country, and with its strong business population there ought to be a proportionate art-loving population. Man cannot work for ever at his daily monotonies, but should rest and enjoy thoughts of the beauty around him, or that which is within reach of us all in everyday life, sent by the Almighty to stir up the better sense within and elevate man to the appreciation of the arts of painting, sculpture, and music. This of course, to gain the proper end, must be the perfection - as near as possible—of life, form, or sound in harmony. ${ }^{114}$

Nairn appealed to Dunedin collectors, who were corrupted by the dictates of fashion, to commission 'competent men' to decorate both public and private buildings with 'decorative' scenes, 'whether pastoral, peasant, or historical, these would help the student both artistically and morally'. ${ }^{115}$ After all, Walter Crane advocated 'the eye' was the receiver of ideas for humanity. Instead of purchasing items from the local importer's 'shop window', Nairn stated 'to those who are studying (let it be in whichever branch), I advise the cultivation of a desire to be genuine, so that giving to the world your mind in any form of art, you would know that you have done it sincerely for the elevation of the minds of the community'.116 Over time, Nairn was commissioned to paint 'decorative art' for community buildings, was the leading portraitist for the New Zealand Supreme Court, and designed stage sets for theatre productions. ${ }^{117}$

In the wake of an industrial age, the primary concern for artists was the public's growing obsession with an ever-expanding and superficial consumer culture.

\footnotetext{
113 Valuation Department Series I, Valuation Rolls, 1890-99 [DCC] and 'Esther, George', The Cyclopedia of New Zealand. http://nzetc.victoria.ac.nz//tm/schol arly/tei-Cyc04Cycl-t1-body1-d2-d30-d4.html. Accessed: 23 November 2015.

114 Nairn, 'Decorative Art', 41.

115 Ibid, 42.

116 Ibid, 41-42.

117 See “"Rob Roy” at the Opera House,' EP, 1 September 1891, 2.
} 
Throughout his 14 years in New Zealand, Nairn reiterated that it was the responsibility of the artist to create beautiful works of art that would detach the onlooker from inhabiting an industrial world preoccupied with social, political and economic disharmony. Once an artist had received proper academic instruction, the 'initiated' painter would be able to create 'decorative' art-thereby transporting themselves or a prospective client into an un-worldly realm of pleasure and a contemplative state of thought. 


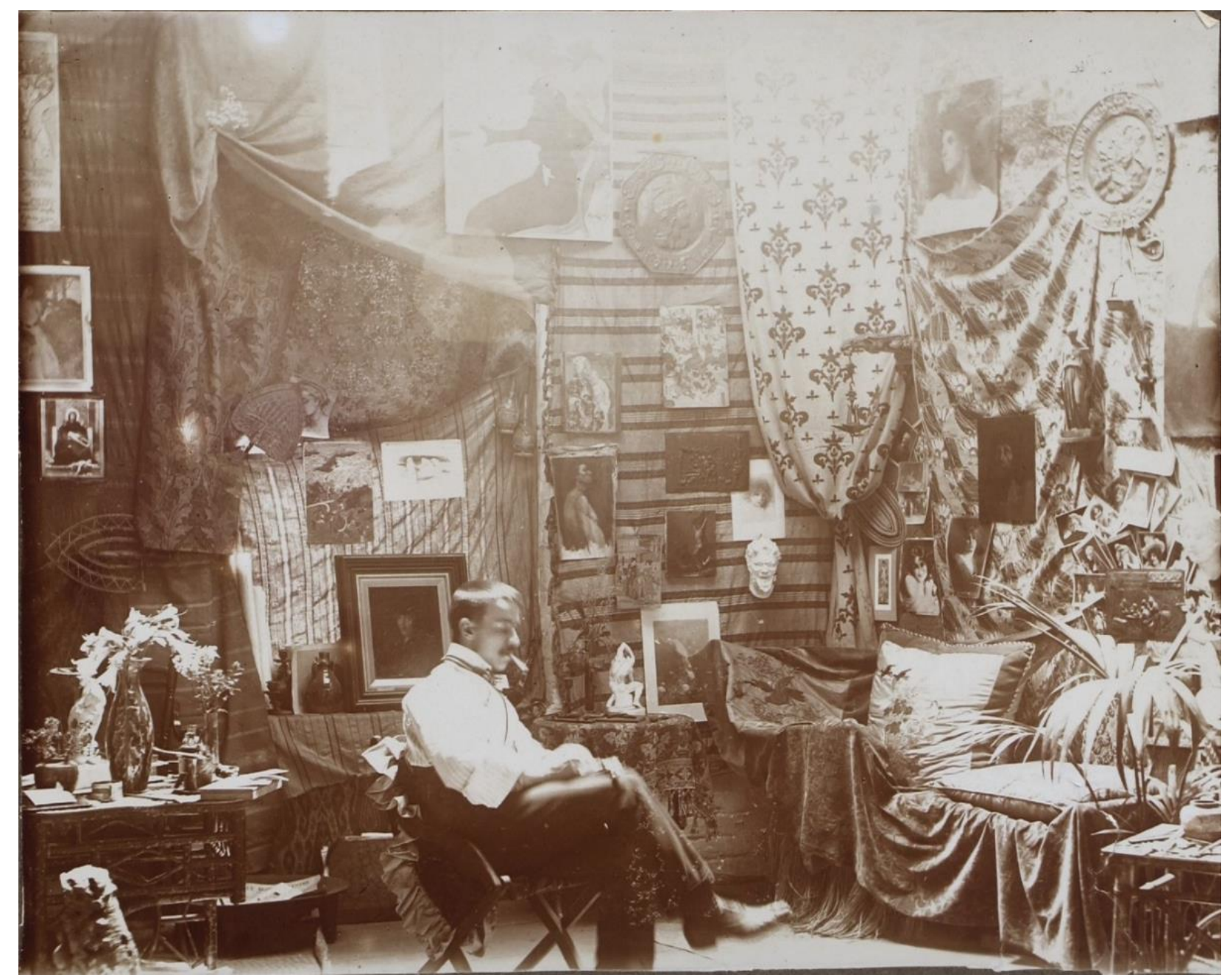

Plate 3: Unidentified photographer, Charles F. Goldie in his Studio, Hobson's Buildings, 1900 (courtesy Auckland Art Gallery Toi o Tāmaki, gift of the Goldie Family). 


\section{Chapter Three}

\section{SEARCH FOR BEAUTY 'SOUTH OF THE LINE': THE ARTIST'S STUDIO AND THE ANTIPODEAN WOMAN}

Studios! - even as we write the word studio, doors fly open to admit for once in the year shoals of eager visitors. Outsiders are always curious about artists and their surroundings; to them the sanctum sanctor um of the painter's house is a mysterious place, draped in tapestry ... it is the sacred meeting ground of a secret society, whose talk is a masonic puzzle to the uninitiated -a laboratory in which ideas are melted down and boiled up, and turned out on canvas by magic, the paint-pot and brushes being the wizard's apparatus. ${ }^{1}$

A romantic notion of the artist's studio was firmly entrenched by the twentieth century. The once-private and mysterious quarters of a professional artist's studio soon transformed, to become multi-purpose spaces. The studio was a sanctuary, where an artist could retreat from the fast-paced hardship of modernity to live, work and socialise. Surviving documentary photographs and sketches of famous artists posing in their oriental treasure-houses, such as the eminent Aesthetes Frederic Leighton and Lawrence Alma-Tadema, provide us with a glimpse of their creative process and bohemian lifestyle. These images of opulent studios were published in illustrated art magazines and circulated around the world, enticing the general public and aspiring young artists to decorate the interiors of their homes, public buildings and workrooms in an Aesthetic or Orientalist fashion. More pressingly, the conception of the studio exuded wealth, artistic knowledge and celebrity status, bestowing a sense of empowerment on the professional artist. The artist became the disseminator of a new-found religion of art, a 'High Priest' of a moral and spiritual worth that would dictate art, fashion and culture. As the title of this chapter suggests, the artist's search for beauty through the decoration of the studio and his home

\footnotetext{
1 'A Gossip about Studios', The Architect, 11, 28 March 1874, 174. Cited: Mark Bills and David Webb, Victorian Artists in Photographs, The World of G. F. Watts: Selections from The Rob Dickens Collection, Compton: Watts Gallery, 2007, 12 and Pamela Todd, The Pre-Raphaelites at Home, London: Pavilion Books, 2001, 150.
} 
served as a model to be emulated, and captivated the minds of an audience as far away as the antipodes.

In the last quarter of the nineteenth century a wave of international artists departed Europe for the South Pacific in search of an ideal beauty. As previously discussed, Nerli was one of these professional artists who would play a significant role in the progress of Australian and New Zealand art. In 1885, the same year that Nerli arrived in Melbourne, another émigré artist was attracted to the vitality of this urban commercial centre. From the outset, the Austrian-born artist Carl Kahler made a favourable impression on elite patrons living in Melbourne. Along with his charm and artistic abilities, he was known for the extravagant décor of a studio that some proclaimed to be one of the finest Aesthetic studios 'south of the line'. ${ }^{2}$ Steeped in Aesthetic culture, Kahler's studio was decorated with masses of objects, including large bronze-gilt frames, peacock feathers, Japanese lacquerware, ornate vases filled with pampas grass, and Turkish fabrics which enveloped intricately carved pieces of furniture in the Rococo and Neo-Renaissance style. These iconic signs of Aestheticism reveal the artist's desire to be surrounded by an assortment of beautiful objects.

Collectors and visitors privileged to be invited into Kahler's studio were reportedly left astounded by the opulence of this interior. One eye-witness recalled their first encounter:

To ascend from the noise, the bustle, and agitation of Elizabeth Street into this tranquil and isolated spot was like walking out of the nineteenth into the sixteenth century. You entered another epoch, and another atmosphere. Everything was quaint, mediaeval, elegant and artistic. The walls were tapestried with old gobelins; the carved furniture suggested ancient palaces and monasteries; the precious bric-a-brac had been gathered from many cities in many lands, and its picturesque arrangement denoted the eye and hand of an accomplished artist. $^{3}$

The extent of Kahler's collection of exotic treasures was revealed in 1890 when the artist disbanded his studio in Melbourne to continue his professional career in the United States. Weekly social magazine Table Talk and the Argus newspaper recorded

\footnotetext{
2 'Herr Kahler's Studio', Age, 15 February 1890, 11. Cited: Montana, 'One of the Greatest Sights of the World', 83.

${ }^{3}$ Gemmell, Tuckett \& Co., Catalogue Raisonné of the Contents of Herr Kahler's Studio, Melbourne: McCarron, Bird \& Co., 1890, 4 (Melbourne: State Library of Victoria).
} 
'the hysteria' surrounding the sale of his prized art and antiques. Despite the firm interest in Kahler's collection, the auction at Messrs. Gemmell, Tuckett \& Co. on 20 February 1890 provoked a degree of negativity from the public. Kahler's studio highlighted Aestheticism as an emblem of elitism and overt decadence to some individuals. Photographs of the studio, published in the sale catalogue, drew criticism in relation to the Aesthete's lifestyle and complete lack of engagement with 'the real' world. Most scholars writing on Aestheticism argue that the ideology itself began to reach a natural conclusion during the 1890s in Europe and the United States. ${ }^{4}$ The conflicting reactions to the sale of Kahler's possessions might allude to the degeneration and inevitable demise of Aestheticism in the Antipodes. However, while it is plausible to suggest Aestheticism was no longer worshipped to the extent it had been almost a decade earlier, there is evidence to suggest the belated arrival of Aestheticism in Australia and New Zealand during the 1880s prolonged the circulation of these ideas well into the early twentieth century.

In 1888 and 1890, Kahler made two visits across the Tasman to visit Auckland studios and market his art to a new audience. His presence caused quite a sensation, especially on his second visit, when enlarged heliotype photographs of his Melbourne studio appeared in Mr Wildman's prominent shop window in Shortland Street, one of Auckland's main thoroughfares. ${ }^{5}$ The scenes of Kahler's studio in Melbourne proved popular to passers-by. Only a decade after these attractive photographs appeared in Mr Wildman's store on Shortland Street, the New Zealand-born artist Charles F. Goldie would inherit Kahler's reputation for working in a studio that even an artist on the Continent would sorely envy. ${ }^{6}$

Goldie's studio was his treasure-house of art. He created a domain based on the promotional pictures of his Parisian teachers, including Bouguereau and Ferrier. How, then, did this young artist become interested in emulating these bohemian painters and their Parisian studios? George Grey, former Governor and sometime Premier of New Zealand, had been impressed by Goldie's early still life sketches at the

\footnotetext{
${ }^{4}$ Calloway and Federle Orr, The Cult of Beauty, 227.

5 Description of Kahler's visitin 'Untitled', NZH, 22 October 1890, 4 and 'A German Artist in Auckland', Observer, 8 November 1890, 12.

6 I will refer to Goldie according to his documented request. The elderly artist wrote to his nephew in 1936 advising 'give my name as Charles F. Goldie'. Refer to Blackley's Goldie, 196.
} 
Auckland Academy of Art in 1891, and supportive of the promising young artist's attendance at the most popular and successful commercial art school in Paris, the Académie Julian. On 3 July 1893, the 22-year-old New Zealander enrolled at the Académie situated on the Rue du Dragon, on the Left Bank of the Seine. Goldie was one of the thousands of international artists gravitating towards the Académie Julian in the 1890s. In H. P. Sealy's animated discussion about his personal experience of the milieu at the art school, he describes the attraction of studying at the Académie and its acceptance of foreign artists:

No part of the world is too remote, no social state too humble, no incapacity too glaring. Everyone is welcome at the Academie Julian in Paris. Even New Zealand, farthest probably of all countries, being almost the Antipodes of Paris, had at one time three representatives in one studio. This was in the early nineties, when Messrs. T. Ryan, C. F. Goldie and the writer, all from Auckland, were at Julian's, while on the walls, among the compositions, may be seen the signature of S. Begg, now well known as an illustrator, who hails from Napier. This and Mr Goldie's pronounced success as a medallist at the Academie, speak well for our future in the World of Art. ${ }^{7}$

Founded by Rodolphe Julian in 1868, this cosmopolitan art school welcomed foreign students. In order to succeed, Goldie learned he would have to adjust to the Parisian lifestyle. There are few surviving letters written by Goldie from Paris, and as a consequence it is not clear whether he frequently socialised with his fellow countrymen (one of whom, Ryan, had already suspended his studies at the art-school on 24 April 1893) ${ }^{8}$ or whether he was a part of a wider social circle at the Académie. One confirmed friendship that Goldie made while studying in Paris is reflected in a portrait Goldie painted of an English-born student, Joseph Kirkpatrick (1872-1930). The portrait of his friend holding his brushes, mahlstick and easel was reproduced in Sealy's 1901 article in New Zealand Illustrated Magazine. ${ }^{9}$ These two Englishspeaking students stand next to each other in an 1897 official group photograph of Bouguereau's class at the Académie [Plate 27]. The considerable length of time both artists spent at the Académie was unusual, suggesting that they both relished learning in an intensely competitive and highly stimulating work environment.

\footnotetext{
${ }^{7}$ H. P. Sealy, 'L' Academie Julian in Paris', NZIM, 5, 1 October 1901, 21-22.

8 Blackley, Goldie, 7.

${ }^{9}$ H. P. Sealy, 'In the Studio: Mr C. F. Goldie's Work', NZIM, 6, 1 November 1901, 147.
} 
The commercial arrangement of the Académie Julian was advantageous for both professor and student. Professional artists working as tutors at the Académie received financial benefit while the students attending classes were under the aegis of some of the most celebrated artists of this period. The tutors imparted their expertise and took the time to teach the required standards of academic drawing. One of these revered artists was the eminent Salon painter of mythological scenes William-Adolphe Bouguereau (1825-1905). Goldie thrived under his tutelage for the considerable duration of 41/2 years from July 1893 to January 1898.

Goldie was placed in the Atelier Bouguereau et Ferrier to learn the methods of drawing from the antique and life. Every month the tutors would alternate. Bouguereau and Ferrier made occasional appearances in the studio and each demonstrated a different approach to teaching-Ferrier, a very 'hands-on' method compared to Bouguereau's honest and gentle demeanour. Needless to say, both teachers' inspirational words had a significant effect on Goldie's earliest works produced in Paris. A letter addressed to his family was subsequently published in the New Zealand Herald in December 1893, confessing the young artist's thoughts on his studies and settling into Parisian life.

I like the school very much, also the students who represent almost every nationality. We have only about forty students in our section of the academy at present, viz., that under Professors Bouguereau and Ferrier, but I understand in winter there will be from 100 to 150. Before commencing work direct from the model, I thought it better to make one or two drawings from the antique first. The studies made were from the 'Venus of Milo' and 'The Slave', after Michael Angelo [sic], the originals of which are in the Louvre. The professor for this month (Ferrier) complimented me on both studies. ${ }^{10}$

This was not the only compliment Goldie received from his tutors at the Académie. Bouguereau expressed his delight that a student would take the initiative to observe, not the life model, but the antique cast first and stated, 'I am glad one of my students had the will to carry his work so far'. ${ }^{11}$

10 'Untitled', NZH, 6 December 1893, 4.

11 Sealy, 'L' Academie Julian in Paris', 17-22. 
In his first few months of study, Goldie informed his family of an enlightened discussion he had with an unidentified Tasmanian artist about the emphasis the French School placed on learning to paint from the life model. His day entailed sitting in a classroom of up to 150 students, for many hours, perfecting esquisses (rough sketches in oils) from the life model. The room was said to be full of pungent 'blue' smoke making it hard for artists sitting at the back to see the model. Goldie utilised the remainder of his time making copies after 'Old Master' paintings and sculptures housed in the Musée du Louvre. It was common practice for aspiring artists in Paris to visit the Louvre. Bouguereau and Ferrier encouraged their students to take advantage of the educational experience that Paris offered by entering the museums and copying art of their predecessors.

The Académie was open to students all year long. Due to the sweltering heat of a Parisian summer, it was commonplace for students to reduce or temporarily suspend their tuition hours at the Académie Julian in favour of visiting museums, travelling, or venturing to the countryside. This time away from the atelier proved invaluable for Goldie. He seized the opportunity to make 'thorough' charcoal and oil sketches after famous paintings by the great masters, including Rembrandt, Géricault, Fragonard, Tiepolo, Prud'hon, and Goya. The Cyclopedia of New Zealand confirms Goldie used his time away from the Julian by going on sketching expeditions to art galleries in Antwerp, Rome, Florence, Venice, Milan, Naples, Amsterdam, The Hague, Rotterdam, Haarlem, Brussels, Bruges, Dusseldorf and London. ${ }^{12}$ It is speculated that on one occasion he visited his brother William, who was adding to their father's financial strains back home by studying medical science in Edinburgh. In 1897 it is claimed Goldie deferred his studies for a short period to attend art lessons with the Royal portrait painter, James Guthrie. ${ }^{13}$ Soon after, he realised the study of anatomy was essential to his practice and enrolled in anatomy classes with Professor Duval at the École des Beaux-Arts in Paris. The discipline adhered to in the French art-school system would enhance his 'realistic' depictions of Māori sitters back in New Zealand.

The vast majority of international artists commencing studies at the Académie would eventually return home. Goldie therefore made an effort to keep members of the art

12 Cyclopedia of New Zealand, (2, Auckland), Christchurch, 1902, 320. Cited: Blackley, Goldie, 194. 13 Ibid. 
fraternity in Auckland up-to-date with his progress throughout his training at the Académie Julian. While living in Paris, Goldie sent a drawing of the Venus de Milo to the Auckland Society of Arts exhibition in March 1894 and was awarded a bronze medal for his efforts. However, despite the result, as an artist who had received training at 'the Mecca' of the art world, Goldie believed his education in Paris rightfully bestowed upon him a pre-eminent status.

By 1897, Goldie had come to terms with his inevitable return to Auckland and had by that time already started to stage-manage his flattering reputation as a Parisiantrained artist. In a letter written to a dear friend, Grace Hesketh, he reported that while studying at the Académie Julian, his friends would often tease him about returning to an 'uncivilised' country and they declared, 'You'll never be able to settle down on that desert island'. ${ }^{14}$ Goldie then explained that his friends knew very little about New Zealand. They would often proclaim 'the Maoriland artist' was electing to leave Paris in favour of a desolate land of men living in make-shift 'mud huts' and hunting wild 'moa'.15 This anecdote of how his friends envisioned life in far-off New Zealand amused Goldie greatly. Despite the playful language and assured tone in his letter to Hesketh, hinting he was in good spirits, the artist's subsequent action in mid1898 suggests he feared the impending prospect of remaining in New Zealand for the rest of his professional life. Unsure of his short-term future, Goldie sought the advice of a fortune-teller in Paris: 'In two years time I am according to prophecy to [be] back in Paris and London for good'. ${ }^{16}$ This must have been reassuring news to an artist who clung to the hope of one day returning to the Continent.

On 29 August 1898 Goldie arrived back in Auckland on board the Waihora, along with a vast collection he had assembled while studying in Paris. ${ }^{17}$ These objects would prove to be an integral part of Goldie's life in New Zealand-decorating practically every inch of Goldie's studio, his family's town house Velitoa located at 47 Pitt Street and the 'French Academy of Art' co-founded with his first teacher, Louis John Steele

\footnotetext{
14 C. F. Goldie to Grace Hesketh (ATL, Ref. A-252-010). Cited: Blackley, Goldie, 10; Taylor and Glen, C. F. Goldie 1870-1947, 15.

15 Ibid.

16 Ibid.

17 'The Waihora', Auckland Star (AS), 29 August 1898, 4; 'Passenger Lists, 1839-1973', (Wellington: Archives New Zealand, Ref. 004436336).
} 
(1843-1917). The collection acted as a comfort mechanism for an artist who felt detached from the wonders of Paris. Goldie made a conscious decision to live among beautiful objects which could momentarily transport him back to his now-vanished bohemian lifestyle in Paris. His assortment of plaster casts, posters, esquisses, Māori and Japanese artefacts, and luxurious oriental fabrics brought a confluence of local and international ideas that were all juxtaposed in this Aesthetic studio. Whether it was a domestic interior or an artist's studio, for a self-confessed Aesthete the decoration of an individual's surroundings represented an extension of themselves. ${ }^{18}$ Although Goldie never openly swore an allegiance to the Aesthetic doctrine, this urge to emulate the fashion for collecting bric-a-brac-an aspect of Aestheticism in its later phase-is apparent in the design of his Auckland studio.

On reflection, Goldie was exposed to the bohemian lifestyle in Steele and Watkins's studio in Victoria Arcade, Auckland before travelling to Paris. In the late 1880s, Goldie had grown weary of a part-time job at his father's timber mill and turned to Steele to find his 'true direction' in life, as a professional painter. Steele was allegedly taught by Alexandre Cabanel and was often described as a bohemian. Adorned with his Turkish fez, he coordinated annual exhibitions for the Auckland Academy of Art (founded in 1889) in rooms adjoining his studio. As President of the Academy, Steele's 'artistic' direction sought to transport an onlooker to another realm: this was a concept indicative of the new-fashioned Aesthetic interior at this time. He successfully created this effect at the 1890 exhibition, where a visitor proclaimed, 'on stepping into the studio ... Auckland is left far behind. You enter into a sort of forest of fern and nikau, and amongst the groves are hung most delightful paintings and studies'. ${ }^{19}$ Another commentary on the exhibition was made by a young female observer. Upon entering Steele's studio she recalled seeing 'yards upon yards of quaint Māori hangings and matting cumbered the floor, and dozens upon dozens of pictures were stacked on every side'. ${ }^{20}$

Following Goldie's departure for Paris, Steele continued to impress the public with the opulence of his studio. The Weekly Standard described Steele's studio in 1894 as

\footnotetext{
18 Macleod, Art and the Victoria Middle Class, 289.

19 'Academy of Art', AS, 30 April 1890, 5.

20 'Auckland Academy of Art', AS, 26 April 1890, 8.
} 
'a combination of art gallery, museum, and general curiosity shop, with himself as a genial showman.'21 It was not until Steele moved his studio to a new location and a photograph of this space was published in a periodical that the extent of his collecting habit was revealed.

In 1901 the New Zealand Graphic published a series of photographs documenting artists' beautifully decorated studios in Auckland [Plate 28]. On the left, Steele's 'cluttered' studio contains rich 'exotic' treasures collected from all parts of the world. Steele's possessions included Afghan swords, Indo-Persian daggers with gold inlay and ivory hilts, inlaid Solomon Island combs, and an ivory Buddha figure from Goa. These items were gifted to the Auckland Museum in 1917.22 In the photograph, soft draperies hang from the ceiling, and rest on top of stacks of empty frames leaning against every inch of available floor space. The studio was rumoured to be filled with objects and is documented in an infamous court case. The son of a famous English landscape painter, Frank Walton appeared before the court in Auckland accused of stealing a meerschaum pipe from Steele's studio. L. J. Steele confessed his studio was so 'packed' with art and curios that he was alerted by the local authorities that the pipe was in fact missing. ${ }^{23}$ The photograph of Steele's studio reveals how this transpired-the interior was consumed by the sheer volume of his collection of art and ethnographic treasures.

At the centre of the photograph featured in the New Zealand Graphic, a New Ireland mask rests inside a box of Steele's utensils used for painting along with oils, mixing solutions and the artist's palette. Steele's own Sketch for the Arrival of the Maoris in New Zealand (1901, Te Papa) is positioned above the painter's box. The framed oil sketch is surrounded by visual clues of Steele's fascination with 'exotic' cultures. Two vases from the Far East, a statuette from the Pacific Islands and Māori curios are arbitrarily placed along a shelf. Above them, on the main wall, hang portraits of Māori sitters.

\footnotetext{
21 'Music, Drama and Art', Weekly Standard, 24 February 1894, 8.

22 'Untitled', Auckland Star, 18 August 1917, 4. Item gifted to Auckland Museum by L. J. Steele in 1917 included: Buddha (8841, 1917.28).

23 'Serious Accusations', AS, 4 May 1888, 3.
} 
The display of Māori curios in New Zealand interiors became increasingly popular during the 1890s and were relatively easy to acquire. They were sold at stores such as Eric Craig's Curiosity Shop, situated in Princes Street, a 'stone's throw' away from Auckland Museum. ${ }^{24}$ This store contained:

... exhibits from the countless tribes of the Dark Continent, from the Sioux, Esquimaux [sic] and other American Indians, from Arabia Felix, from Madagascar and the islands of the Indian Seas, from Australia and New Guinea. The collection of New Zealand curios is unique and of the greatest value. $^{25}$

Steele held a keen appreciation for the formal characteristics of Māori art and 'possessed' these objects for their 'exotic' appearance. The New Zealand Graphic's feature on 'Some Auckland Studios' shows another Auckland artist, Frank Wright, had a shared interest in displaying relics of ancient cultures on the feature wall of his studio. Medieval armour and Māori weaponry are placed side-by-side, provoking enlightened discussion at social gatherings held at Wright's studio to view his latest painting and observe his collection. ${ }^{26}$

In her PhD thesis on the European uses of Māori art, Anna Petersen proposed that Aestheticism, with its disparate styles and considerable attraction for possessing exotic artefacts, led to the aestheticisation of Māori and Pasifika objects in the New Zealand home. ${ }^{27}$ The 'House Beautiful' and Aesthetic decoration was adapted to encompass traditional artefacts of ancient cultures native to the antipodean region. An example of Māori taonga and Pacific objects being integrated into A esthetic designs within the home is found in Alexander Horsburgh Turnbull's private residence, 'Elibank', in Wellington [Plate 29]. Turnbull, photographed in the 1890s with his brother Robert and friend E. F. Hadfield, is seated in his living room surrounded by his collection of artefacts from ancient cultures. On the wall there are fine examples of medieval European, Chinese, Japanese, Middle Eastern, and Pacific forms of weaponry, set against a decorative wallpaper design. The Aesthetic interior

\footnotetext{
24 The Auckland Curiosity Shop', Hot Lakes Chronicle, 7 October 1896, 2.

25 Ibid.

26 'Personalities', Observer, 15 August 1891, 7.

27 Anna Petersen, 'The European Use of Māori Art in New Zealand c.1890-1914', At Home in New Zealand: History, Houses, People, Barbara Brookes (ed.), Wellington: Bridget Williams Books, 2000, 65.
} 
of Turnbull's home is one of luxury in excess. While Aesthetic patrons in Europe and the United States idolised the simplicity of Japanese art in domestic interiors, Turnbull's living quarters show how the dispersal of Aestheticism to New Zealand resulted in a further development-an adaption of Aestheticism in a colonial context. At the turn of the century in New Zealand there was a new-found desire to, not only display art from the Far East, but also integrate Māori and Pacific art into both public and private Aesthetic spaces.

Petersen's observation of Māori art in New Zealand homes during this period can be applied elsewhere-namely, to public art galleries and studios. As early as the late 1880s, while Goldie exhibited his student works at the New Zealand Art Students Association, Kennett Watkins decorated the gallery space with flags, nikau palms and Māori curios. ${ }^{28}$ But it was predominantly Goldie sharing an Auckland studio with Steele (both before and after Goldie's studies in Paris) which had a significant effect on the young artist's skill set and aspirations to live as a bohemian. His teacher often reminded him 'to paint what you see and not what you know'. ${ }^{29}$ Steele's anecdotes inspired Goldie to learn the traditions of the French School and yearn for the spectacular lifestyle a bohemian artist could lead. Only a few months into his studies at the Académie Julian:

Mr. Goldie expresses his indebtedness to Mr. L. J. Steele, of his city, for the manner in which he has trained him, so that on entering one of the principal art schools of the world, he had nothing to unlearn, showing that the teaching of his Auckland master had been the right direction. ${ }^{30}$

Steele forewarned his protégée about the intense learning environment he would encounter but reinforced how these lessons would ultimately increase his understanding of art. Goldie sought to re-create the romanticism of the artists' studios of Paris in his homeland. His obsession for collecting art, books and curios culminated in his Auckland studio being filled with all manner of objects. The only surviving records of the contents of Goldie's studio are conveyed in the words of his friends, sale valuations and the miraculous photographs supplied to periodicals. The remaining section of this chapter will analyse surviving evidence and propose that

\footnotetext{
28 'New Zealand Art Students' Association', NZH, 15 October 1884, 5.

29 'Academy of Art', AS, 29 April 1890, 8.

30 'Untitled', NZH, 6 December 1893, 4.
} 
Goldie's highly decorative studio was the embodiment of a subset of Aesthetic ideas that were transformed within a colonial context.

\section{GOLDIE'S 'TREASURE-HOUSE OF ART'}

For approximately two years (1898-1899), Goldie shared a studio and teaching institution, 'The French Academy of Art', with Louis J. Steele at Hobson's Buildings, Shortland Street in Auckland. Trading on their French credentials, they opened their studio doors to aspiring artists, revealing the masses of continental and 'exotic' artefacts accumulated on their travels. During this period, Goldie and Steele completed their collaborative 'history' painting The Arrival of the Maoris in New Zealand, 1898 (Auckland Art Gallery Toi o Tāmaki), a composition inspired by Goldie's copy of Théodore Géricault's Raft of the Medusa. However, towards the end of 1899, a degree of hostility arose between the two artists. This may have been provoked by the constant praise that Steele's star pupil was beginning to receive, a pupil destined to surpass the reputation of his former teacher. The favourable reception of Goldie's paintings eventually proved too much for Steele and signalled an end to their professional relationship. As a result, Goldie chose to move his possessions to the top floor of the Hobson's Buildings, where his independent studio became his 'palace' of show and entertainment.

Richard Arnold Singer, an Auckland-based solicitor and habitué of the studio, wrote of the beautiful sights he discovered in Goldie's atelier in Auckland:

Yet, mount to the top of the extremely prosaic Hobson's Buildings, in the extremely prosaic Shortland Street, Auckland, and there will be found a studio full of brilliant studies in oil and chalk, of most delightful curios from all parts of the world, hung and laid with the quaintest mats and carpets, all disposed in the ordered disorder that speaks of a true artist's touch, and above all, adorned with pictures that but little knowledge will convince to be the work of a man who will one day be famous in lands where not alone art, but history, also has an appeal. ${ }^{31}$

Singer's favourable impression of the studio includes a common expression often used to describe an Aesthetic space-the 'ordered disorder' that only an artist can

\footnotetext{
31 Richard Arnold Singer, 'Mr C. F. Goldie and his Pictures', Triad, 11, 9, 1 December 1903, 10-12. Cited: Blackley, Goldie, 179-80.
} 
envision and make beautiful. It is only on viewing surviving photographs of the studio that we begin to understand Singer's reaction to this luxurious and cosmopolitan setting.

Goldie collected a plethora of objects from every corner of the world, both historical and contemporary. His urge to collect exotic curios is explained in Charlotte Gere's book Artistic Circles, where she suggests the conception of an exotic studio proved popular and is ultimately where Orientalism and Aestheticism meet. ${ }^{32}$ The Aesthetic Movement in England, France and the United States elevated the public's perception of the artist's identity. At this time, there was a dramatic shift in the representation of an artist, who in the past, had been labelled 'poverty-stricken' and 'scarcely respectable'. Aestheticism instigated not only a cultural revival of art, music and literature, but introduced a 'theological intensity' in an increasingly secularised society. This signalled the ascendance of the artist as a cultivated individual and superior being. ${ }^{33}$

Photographs of Parisian and London studios featured in New Zealand periodicals. In the New Zealand Illustrated Magazine, Sealy's 'L'Academie Julian' includes an extraordinary image of Goldie's teacher in Paris, Gabriel Ferrier (1847-1914). ${ }^{34} \mathrm{He}$ sits in his Oriental-inspired studio surrounded by prints, fabrics, sculptures, and original paintings. As arbiters of creative taste, professional artists regarded their studios as autobiographical platforms for openly communicating their talent, sophistication, success, and celebrity status to a 'global' audience. Hence, Goldie wished to emulate such scenes in his own Auckland studio through the local press.

Akin to the romantic studio scenes of his professors in Paris, Goldie stage-managed the photographs taken in his Auckland studio. He marketed himself as a successful graduate from a reputable art school on the Continent and a leading academic painter in the antipodes. A part of Goldie's marketing strategy was to maximise his exposure through art and society magazines. In November 1901, Sealy wrote a lengthy article

\footnotetext{
32 Charlotte Gere, Artistic Circles: Design \& Decoration in the Aesthetic Movement, London: V\&A Publishing, 2010, 81.

33 Bernard Denvir, The Late Victorians: Art, Design and Society 1852-1910, London and New York: Longman, 1986, 59.

34 Sealy, 'L'Academie Julian in Paris', 19.
} 
for the New Zealand Illustrated Magazine on the wonderful scenes found in Goldie's Auckland studio. 'In the Studio' provides an intimate glimpse of Goldie sitting amongst his collection in a secluded area of his studio [Plate 3]. With a cigarette dangling from the corner of his mouth, he looks very debonair in dark trousers, dress shoes, white shirt, and bow tie. Notably, Goldie does not make any conscious effort to interact with the camera lens. The photograph therefore acts as a keyhole, seemingly allowing the viewer to enter the studio undetected to witness the bohemian lifestyle of the professional artist.

Accompanying the photograph, taken by an unknown individual, Sealy writes a brief description of the attractive elements he encountered in Goldie's studio:

Among the many treasures that surround the walls of the studio, some visitors would be most attracted by the large collection of sketches, evidently painted by various hands and by artists of divers[e] nationalities. Many of these rough sketches exhibit great vigour in the drawing and colour, and the artistic skill shown in the composition of some of them suggests the making of great painters in the future. These sketches or esquisses, as they are called, have been mostly painted for the usual weekly competition, described in an article on 'Julian's' in last month's magazine. They display the freer hand of the pupil who has allowed his artistic sentiment to have full swing. Apart from any intrinsic value they may have, these sketches are always highly prized by the students in after years, more especially, of course, when, as is often the case, the signatures become famous in the Art World of Paris and the Continent. 35

One of these esquisses from his time at the Académie can be seen on the main wall, to the left of the artist, and positioned directly at the centre of the photograph. The oil sketch of a life model was presumably undertaken at the Académie Julian within approximately two to five days for the weekly concours. Unframed on unstretched canvas, the severe angle of the male torso standing in profile suggests its maker was sitting relatively close to the model. ${ }^{36}$ For the artist, now very distant from Paris, this

\footnotetext{
35 Sealy, 'In the Studio', 147.

36 The maker of this sketch is unknown. It might have been painted by 'the hand' of a fellow artist in Paris. Alfred O'Keeffe, an artist based in Dunedin, studied under the tuition of Benjamin Constant at the Académie Julian in 1894. On his return, he established an Aesthetic studio in Princes Street, Dunedin. A visitor noted that he also had 'examples of the work done by three of his fellow students in Paris - Mr H. L. Hilderbrand [sic], MrJames Quinn, and Mr W. Linde [sic]'. See 'Dunedin Artist in their Studios: No. 10, Mr A. H. O’Keefe [sic]', OW, 10 March 1909, 50; 'Untitled', ES, 18 July 1895, 2.
} 
sketch acted as a reminder of the wonders an academically trained painter could achieve in a short period of intense study.

The variety of art objects surrounding this oil sketch offer an insight into the diverse and lively atmosphere that Goldie experienced in 1890s Paris. To the right of the study of a male torso, Goldie pinned his rough oil sketch of The Crucifixion, after Prud'hon (private collection) to the wall. This sketch was one of the 13 small copies after monumental paintings by 'Old Masters' at the Louvre [Plate 30]. ${ }^{37}$ On the right there are two more examples of Goldie's sketches, including The Head of Christ (Ecce Homo) and immediately behind the artist is a framed copy after a Dutch painter, David Bailly's Portrait of a Young Man, 1637 (Louvre).

On the table beside Goldie, a miniature plaster cast figure of the écorché after Michelangelo rests on a hand-knotted Caucasian fabric. This cast, attributed to the great Renaissance master, was omnipresent in the studios of celebrated artists. It was believed to be a great learning tool as the figure showed extreme torsion of human musculature and conveyed a distressed expression on the face. Hanging to the right of the écorché, the head of a faun protrudes out of the main wall. Both plaster casts might have acted as visual aids, where he sought for heightened expression in certain works, for example, Aperahama Rairai in A Centenarian: Aperahama, aged 104, 1908 (private collection).

Goldie has thought about the systematic groupings of his possessions into a logical order. He constantly moves his beloved objects around the room. Patterned fabrics overlap, blocking windows to the outside world. To the far right of the photograph, nestled amongst elaborate folds of muslin, are postcards of Edwardian and Parisian beauties (several taken by the French photographer Léopold Reutlinger) [Plate 31]. ${ }^{38}$ In the centre, Tuscan Chianti bottles float next to a Dutch study of a Mother and Child. On the floor near the intricately carved oriental table, a French newspaper rests in a traditional kava bowl from the Pacific Islands. Woven fans are scattered throughout the studio, partially covering sketches and photographs. These items

\footnotetext{
37 See 'Copies of Old Masters', AS, 7 July 1920, 12.

38 Goldie reported to Grace Hesketh that he had his portrait taken at the Atelier Reutlinger in Paris, in 1898; see, 'C. F. Goldie to Grace Hesketh', (Wellington: ATL, Ref. A-252-010/013).
} 
from all over the world are placed next to one another to conjure feelings of the 'exotic' and the ownership of such objects signalled his status as a successful artist.

On the far left, Pacific fans frame a reproduction of Bouguereau's Virgin of Consolation. Ironically, on the opposite side of the studio, a Pacific fan threatens to cover a small photograph of his former teacher, Bouguereau, which is situated underneath a gargoyle wall mount in the corner. Above the gargoyle is a portrait of an unidentified woman in three-quarter profile with roses in her hair. This portrait is significant as it features in one of Goldie's earliest known paintings Study of Still Life, c. 1890 (private collection) and hence predates his time in Paris [Plate 32]. In this still life there are elements of Aesthetic tastes-a Chinese jar filled with his brushes and peacock feathers protrude out of a slender green vase on the table. In an exquisitely gilded frame, the artist's mahlstick rests against the portrait in the foreground. This early still life reveals that, even before Goldie's time in Europe, he already had an 'eye' for collecting all manner of objets d'art and assembling them in a bric-à-brac fashion. On returning to examine the photograph more closely, there are peacock feathers framing the portrait. Whether this is done for purely decorative purposes or to symbolise his allegiance to Aestheticism is unknown, but it is undeniably a curious addition to this opulent room.

Parisian studios were covered in rich tapestries and contained Japanese fans, lithographic posters of Parisian life and antique sculptures-a juxtaposition of art from Europe and 'the other', both historical and contemporary. An artist's studio was no longer perceived to be strictly a workshop, but functioned as a reflective space, where the artist could gather his thoughts and find inspiration. A divan is situated in the corner, adorned with exquisite silks and embroidered cushions from the Far East, enabling Goldie recline on the sofa and observe his 'exotic' possessions. The main wall features three examples of Japanese woodcuts. By the 1890s, there was an increasing demand for Japanese ukiyo -e prints and Goldie obviously felt compelled to collect them. Each print is pinned to swathes of decorative fabrics covering every inch of wall space. One Japanese print, located between the Julian sketch and the copy of The Crucifixion, shows two women dressed in kimono. The second print, positioned above the metal work, has an outline of trees, while the third seemingly shows a 
flood. These prints can be identified as Japanese ukiyo-e prints due to their size, striking simplicity and vertical blocks of traditional text.

This intimate glimpse of Goldie relaxing in a corner of his studio also provides further evidence to suggest the young artist was intrigued by Japonaiserie and its effect on Western art. Positioned at the top of the photograph, partly cropped in the upper centre, is Divan Japonais, a famous colour lithographic poster designed by Henri Toulouse-Lautrec [Plate 30]. During the 1890s, Lautrec was commissioned to portray café-concert scenes in Haussmann's urbanised Paris. He chose to base his designs on the simplicity of line and block colour found in Japanese ukiyo-e prints. The outline of a solid black slender figure in the foreground of the composition is the dancer Jane Avril. She holds a fan while seated on a bamboo chair. Lautrec depicts Avril in profile, listening to one of her favourite singers, Yvette Guilbert, who is partially cropped out of the poster. The singer appears on stage as a headless figure but is instantly recognisable by her iconic black gloves. The photograph's overexposure has left a faint outline of Guilbert and the top hat of the music critic Edouard Dujardin, who sits behind Avril.

Lautrec's Divan Japonais was designed in 1893, the year Goldie arrived in Paris to start his academic training. At this time, the interior of the Café du Divan Japonais was being re-decorated with Japanese lanterns and bamboo furniture. Lautrec was commissioned to advertise the latest changes and to promote the nightlife of Paris. Open air cafés chantants were attractive settings, enticing diverse groups of Parisians to socialise at these dance halls. In Roger Blackley's monograph Goldie, he suggests it is very likely the young art student attended the notorious social event for the art students of Paris, the Four Arts Ball (Bal Quat'z' Arts) at the Moulin Rouge. Goldie witnessed these kinds of café-concert scenes devised in Lautrec's Divan Japonais and participated in the fashionable activity of collecting the racy lithographic posters, especially those by Lautrec, as they were a new form of inexpensive art. Goldie's lithographic impression hung on the wall of his studio to remind him of the atmosphere or certain events experienced in Paris. ${ }^{39}$

\footnotetext{
39 Bill Hill to Allan Jonson, The Quartier Latin, 1 July 1896, 19. Cited: Blackley, Goldie, 10, 194.
} 
Goldie's love for all things Japanese is present not o nly in his ukiyo-e prints and Lautrec's poster but also in the oriental objects found elsewhere in the studio. His ambition to re-create a continental treasure-house of art in his Auckland studio is confirmed in a rare surviving photograph that the artist carefully concealed between two pages of a scrapbook, now housed in the collections of Auckland Museum [Plate 35]. The 'personal' quality of the image and the nature in which this miraculously preserved photograph was kept in one of Goldie's scrapbooks suggests it could have in fact been taken by the artist with his own camera. This photograph differs greatly from the carefully orchestrated scenes of Goldie's studio published in periodicals

[Plate 36]. Instead, the sepia photograph shows a secluded section of the studio, an area that remained hidden from the world. Peacock feathers, seen in the ceramic vase on the left, form a familiar element of Aesthetic decoration. Note also the presence of the Japanese four-panelled screen, kakemono (wall hangings) featuring bird designs, and a wooden hanging lantern in the top-right corner. In the centre of the composition are plaster copies of the Dancing Faun, the écorché and a bust of Agrippa. Discarded on the floor in front of the antique casts is a korowai (Māori cloak) and, to the left, a waka hoe (canoe paddle) rests against Goldie's compositional studies of The Finding of Moses, 1896 (private collection) and The Betrayal of Christ, 1896 (private collection). Several portraits of Māori sitters, including Goldie's One of the Old School, are framed in hard-edged kauri mouldings and arranged in an orderly fashion. This harmonious layout contrasts with the piles of art magazines and books littered across the studio's floor, partially covering the korowai he would often use to 'dress-up' his guests or supply for his Māori sitters to wear in formal portraits [Plate 37].

\section{'THE MAORILAND PAINTER'}

In New Zealand's art history Goldie is predominantly revered as the painter of Māo ri. The academic portraits of Māori sitters hang on the main wall and overlook his collection of curios scattered throughout the studio. Goldie's hyper-realist style and interest in 'exotic' primitivism are captured in photographs of his 'ethnological laboratory'. The incorporation of 'exotic' artefacts within the artist's studio are indicative of concepts devised by the founders of Aestheticism in the 1860s, where beauty was found in inanimate objects. 
Goldie's Auckland studio was not solely used as a workroom but was a fashionable retreat to host his friends and family on social occasions. His studio was a room of entertainment, where his visitors could peruse the ro om looking at wonderful art objects and curios obtained during his trip to Europe, analyse original paintings and, on rare occasions, meet some of his Māori sitters in person. Alfred Hill, a composer recalled his good fortune one evening while visiting Goldie's studio:

When the light failed for a painting he [Goldie] would say, 'Now, Alf, here's your chance; you can stay with this tattooed Maori for a while'. This would mean that, if the Maori was in the mood, he would sing an old chant or lament. He might even get excited and do a war dance that would shake the floor. This, of course, was my opportunity, and I never went to Goldie's studio without pencil and manuscript paper. When Goldie returned I was whistling and singing it, and I said: 'Listen to this. I've got a world beater! I sat down at his old piano and thus a song was born'. ${ }^{40}$

The purpose for creating artistically furnished studios was to find inspiration and forms of self-expression. This site of creativity obviously had quite a significant effect on Goldie's friend, who felt completely at ease in the studio and arranged a composition on the artist's piano.

On 24 May 1902 the New Zealand Graphic published a photograph of Goldie sitting in his studio, looking every inch the successful antipodean painter [Plate 38]. The photograph of Goldie's studio is centred on the page with four examples of his early portraits of Māori. However, the artist's versatility in painting the 'likeness' of both Pākehā and Māori subjects was acknowledged in the local press:

Though Mr Goldie is the special exponent of the Maori, he does not confine himself entirely to one subject, and has executed some very fine portraits of several Auckland celebrities. ${ }^{41}$

Goldie inhabited a world of the social elite living in Auckland and, on his return from Paris, his abilities as a portrait painter were recognised by high-ranking public officials. Goldie also found time to paint members of his family, for example, the large portrait of his mother Maria Goldie and also one of his brothers Frank Percy Goldie.

\footnotetext{
40 Undated newspaper clipping, Goldie Scrapbook, 11, (Auckland War Memorial Museum, MS-438); Alister Taylor and Jan Glen, C. F. Goldie 1870-1947: His Life and Painting, Martinborough: A. Taylor, 1977, 21-22.

41 'Mr C. F. Goldie', OW, 24 December 1902, 6.
} 
They are both positioned in three-quarter profile and dressed in formal attire. Another intriguing portrait of a family member appears in a photograph published in the New Zealand Graphic. Resting at his feet is a portrait of the artist's sister, Violet Elsie Goldie (known as Elsie), entitled Sorrowful Moments, c. 1900 (private collection) [Plate 39]. In contrast to the formal attire worn in other portraits of his family, Goldie depicts his sister Elsie as a youthful beauty in an evening dress and posed in resolute profile. The subject and composition emulates the fashions and inactivity present in William-Adolphe Bouguereau's classical beauties, for example, Irène, 1897 (private collection) [Plate 40].

Goldie painted his sister Elsie as a glorious vision of youth in a white dress with revealing décolletage. ${ }^{42}$ As the poetic title suggests, she lowers her head slightly to the right in strict profile view. Her sorrowful expression is poignant as Elsie would never marry..$^{43}$ His portrayal of Elsie emulates the hallmarks commonly found in Aesthetic portraits of female beauty where 'her eyes focus not on us but on something elsewhere, to the side, or perhaps not in the external world at all'. ${ }^{44}$ The bust-length painting of his sister is an intimate and nostalgic scene of an antipodean woman dressed in classical drapery. The figure's thick brow, dark hair tied up with an ornamental fillet, and floral detailing on the oriental screen beh ind her are all visual components that link her to the aestheticising mode of portraiture promoted during this period. ${ }^{45}$ Goldie's Sorrowful Moments has no narrative. Instead, he replaces iconographical meaning with the representation of the elegance and beauty of the female form. Ambiguity over lack of visual clues to identify the sitter, oriental screen and muted colour palette in the background are also other features linking this portrait to aspects of Aestheticism.

\footnotetext{
42 A page in Violet Elsie Goldie's autograph book contains a conté drawing by Goldie. She wears the same outfit with her hair dishevelled at shoulder length. 'Goldie, Elsie, Writing Album', c. 1900, conté on paper, 197 x 156 mm, (Wellington: Museum of New Zealand Te Papa Tongarewa, Ref. CA000253/001/0001).

43 Jemma Field, 'Charles Frederick Goldie, Sorrowful Moments', Auckland: Webb's Auction House, August 2011. www.webbs.co.nz/auction-item/sorrowful-moments. Accessed: 14 July 2015.

44 Cult of Beauty, 66-67.

45 Glazer and Merrill (eds.), Palaces of Art, 108.
} 
The Otago Witness replicated the photo used in the Graphic and beautifully describes the significance of the artist's achievements in their full-page feature article published in December 1902:

Mr C. F. Goldie in his Studio-Here we have the artist at home, surrounded by his Lares and Penates-the triumphs of his own pencil, and the free-will offerings of his friends. The artist seems to be sacrificing to the goddess Nicotine, even while he works or pretends to work, and from the glimpse thus afforded of his comfortable, even luxurious quarters, adorned with palms and ferns, and furnished with easy-chairs and rugs, we can well credit the statement which says that this is the most artistic studio south of the line. ${ }^{46}$

The decorative arrangement of an artist's studio was an extension of the individual and contributed to the public's perception of his moral, spiritual and creative worth. Goldie orchestrated the compositional layout of the photographs taken in his studio. Notice how the artist has positioned himself in the centre with his brush and pale tte in front of his latest painting. His possessions include esquisses on the wall (by himself and other artists of multiple nationalities), miscellaneous knick knacks, Māori curios, plaster casts, and an assortment of used and unused frames provided by local art dealer and framer, John Leech Ltd. ${ }^{47}$ The artist's involvement in crafting his public image is noticeable when analysing a chronology of his photographs in New Zealand periodicals. His strategic placement of plaster casts, fabrics, curios, and paintings are obvious through his constant alterations to details in the studio. Goldie's marketing strategy was to declare himself a true bohemian painter living in the antip odes. The studio's atmosphere was attuned to those of his Parisian teachers, but with the inclusion of Māori curios this artist, perhaps unknowingly at times, took ideas from an artistic philosophy current in Paris and London and adapted it successfully to local conditions.

\footnotetext{
46 'Mr C. F. Goldie', OW, 24 December 1902, 6; Blackley, Goldie, 17.

47 Roger Blackley, 'As Rembrandt would have painted the Māori', Auckland: Gow Langsford Gallery, 2013, 2-3.
} 


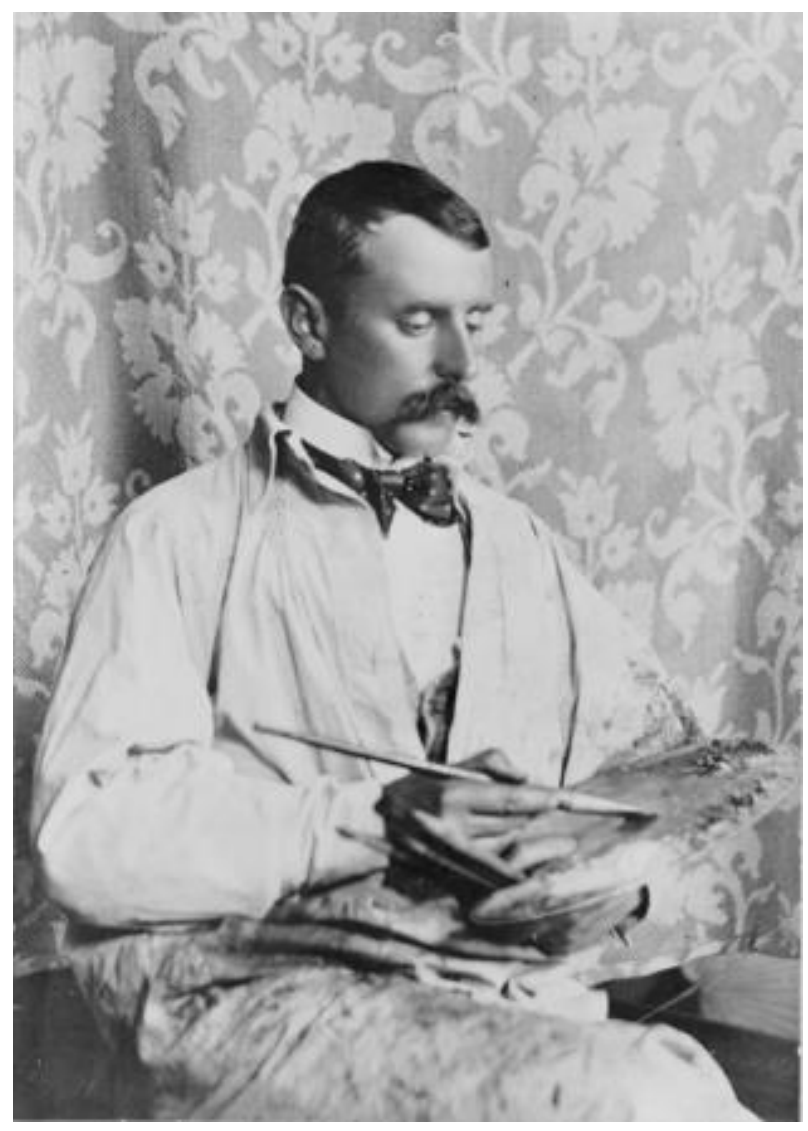

Plate 4: (Above) James McLauchlan Nairn with a palette and paintbrush in front of a 'decorative' wall hanging. Photograph taken in 1897 by J. Hendry. (Wellington: ATL, PAColl-6853).

Plate 5: (Below) 'Mr Goldie at Work on The Child Christ Before the Elders, c. 1901'. In New Zealand Illustrated Magazine, 1 November 1901, 148.

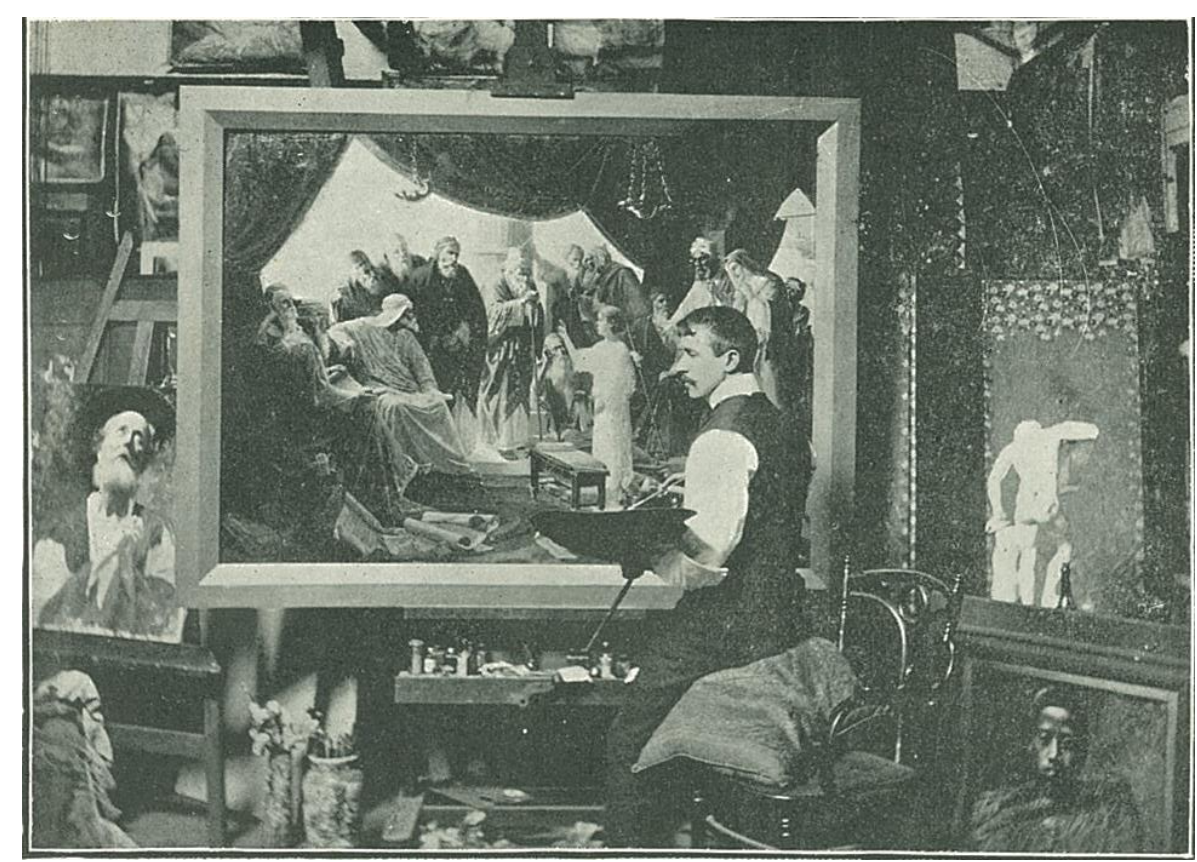




\section{CONCLUSION}

In existing analyses of New Zealand's art history, the influence of Aestheticism in New Zealand has generally received little, if any, attention. Scholars Gordon H. Brown and Ann Calhoun have acknowledged the presence of Aestheticism in their respective texts, but gloss over its significance to provincial art histories, particularly here in New Zealand. They merely refer to Aestheticism as a precursor to the Arts and Crafts, Art Nouveau and Symbolist movements. ${ }^{1}$ I have sought to show this brief assessment of the impact of Aestheticism in New Zealand culture is insufficient.

My account has indicated that, during the latter part of the nineteenth century, multiple art movements were arriving on our shores within a short period of time, overlapping with one another to create a distinctive amalgam of artistic ideas and practices. Australia and New Zealand were not inheriting a sequential chronology of definitive art movements from Europe. Due to our geographical isolation, these ideas arrived somewhat belatedly and by various means. Aesthetic attitudes were already featuring as early as 1881 in the local press and theatre companies were touring Gilbert and Sullivan's satirical operetta throughout Australia and New Zealand in 1882. It is therefore inappropriate to claim artists such as Nerli, Nairn and Goldie were the first to introduce Aestheticism to a New Zealand audience. My findings suggest the public were already familiar with the leading proponents of this sensibility, such as Wilde and Whistler, and with some of the iconic signs of Aestheticism through literature, the popular press and theatre productions from Europe. In illustrated periodicals such as The Studio, images of opulent studios were circulated around the world, enticing the general public and aspiring young artists to decorate the interiors of their homes, public buildings and workrooms in an Aesthetic or Orientalist fashion. Therefore, when Nairn referred to the term 'Decorative Art' in his 1890 lecture and Goldie set up an opulent studio in Auckland, the bourgeois

\footnotetext{
${ }^{1}$ Galbally, 'Aestheticism in Australia', 124.
} 
public were already well-informed as to the components of this far-reaching international phenomenon.

Nairn and Goldie's art practices have been placed in opposition to each other-the Impressionist versus the Academic painter. My research suggests that we should no longer treat these artists as exclusively representative of two polarities of art. In reality, when seen through an Aesthetic lens, there are certain elements which Nairn and Goldie both share, including their endorsing of the French School, creating beautiful interiors and their forging of 'superior' bohemian lifestyles in New Zealand. To be clear, for an artist to be associated with the term Aestheticism does not necessarily mean an individual needed to be a fully-fledged member of the cult of beauty. Despite differences in style-for example, Goldie's hyper-realism and Nairn's Impressionistic flair - they both subscribed to a life of exclusivity and beauty which relied upon society's recognition of their cultivated status. ${ }^{2}$

Both artists studied in Paris, the city of bohemian lifestyles. In the nineteenth century, the term 'bohemian' conjured a specific look to an individual-the eccentric longhaired fashionable dandy. However, over time the characteristics associated with a bohemian artist were revised. Art magazines published photographs of the esteemed painters of Europe showing them to be well-dressed, sophisticated gentlemen posing in their luxurious studios.

Nairn and Goldie also took pride in their appearance. Nairn explained to one of his pupils: 'Be rational, one need not grow unkempt locks and try to be as much unlike other people as possible to be an artist'. ${ }^{3}$ In photographs of the two artists, they each pretend to be at work with their palette, mahlstick and brushes-Nairn, positioned in front of a decorative curtain [Plate 4], and Goldie, sitting in profile with his collection of paintings and curios [Plate 5]. Yet, on looking more closely, one finds that both Nairn and Goldie have slicked back hair and are wearing semi-formal attire-a bow tie, white shirt and trousers - hardly the most appropriate set of clothes for an artist to paint in. Their urbane appearance, while posing with their palette and brush, echo the 'celebrity' images commonly found in European art magazines. These

\footnotetext{
2 Ibid.

3 'The Late Mr J. M. Nairn by One of his Pupils', NZIM, 1 May 1904, 138.
} 
photographs show two artists who truly believe they are the arbiters of taste in this country. After all, Nairn made it known that critics no longer had the right to comment on matters of art and the greatest compliment a painter could receive was from his 'brother artist'. This suggests that only those educated in 'true art' could recognise the beauty of his decorative art.

My research has suggested the strengthening urban middle-class populous in Auckland, Dunedin, Christchurch, and Wellington were already familiar with the concepts associated with Aestheticism. With the rise of an 'art-loving' public, Nairn and Goldie established a similar clientele of middle- and upper-class professionals. Nairn invited a mixture of artists and prominent businessmen to the Wellington Art Club exhibition, including William Hughes Field, a solicitor and Member of Parliament. He continued to show his knowledge of a Whistlerian design aesthetic by experimenting with stylised invitations and executing an Aesthetic ambience par excellence at the 1894 exhibition. Similarly, in Auckland, Goldie built a reputation for the 'likeness' he captured in exquisite portraits of public officials. Both of these artists were socialising with the upper echelons of society in New Zealand to further their artistic ambitions.

As I have previously stated, art historians writing on Aestheticism in Europe, the United States and Australia claim the Aesthetic 'craze' was reaching its natural conclusion in the early 1890s. This trend is reflected in New Zealand periodicals, where articles on Aestheticism begin to lessen after news of Oscar Wilde's trial and conviction in 1896. However, aspects of Aestheticism were still present in exhibitions and artists' studios well into the twentieth century in New Zealand. This could be attributed to a culmination of factors - the belated arrival of Aestheticism to the South Seas or, perhaps even more plausible, the continued influence of 'Old World' artists, such as Goldie, who experienced the wonders of nineteenth-century Paris and blatantly refused 'the modern'. 4

Signs of Aestheticism can be found around the turn of the twentieth century, when beauty was thought to reside within exotic artefacts, including Māori curios. The language used by Watkins in 1883 through to Goldie implementing these ideas in his

4 C. F. Goldie, 'Battle of the Schools: Modernism Condemned', NZH, 28 September, 1934, 15. 
Auckland studio is both nationalist and informed by a wider global movement, Aestheticism, in which 'exotic' or 'indigenous' objects were seen to be sources of beauty. In my research I have argued that, instead of looking elsewhere for objects that would instil this sense of beauty in art and life, artists such as Goldie admired the simplicity of line in ancient artefacts closer to home, spe cifically Māori art. Watkins, in pressing for a national art, claims that we have to call on our distin ctive indigenous heritage. In this thesis I have proposed that his call is ultimately derived from the Aesthetic Movement.

As discussed in previous chapters, Aestheticism encompasses the simultaneity of both local and international influences in our art. This bears out the achronological confluence of local and European art trends one is able to detect in provincial cultures such as New Zealand. For example, in Nerli's The Sitting there are Polynesian artefacts - a headdress and fans-lying next to Middle-Eastern embroideries and Japanese silk wall hangings; Goldie's studio shows off Māori and Pacific curios next to Japanese screens; and a photo of O'Keeffe's studio has a plaster cast of Michelangelo's The Slave behind a large Japanese porcelain vase [Plate 41]. By collecting 'exotic' items to fill their studios, these artists were following Kennett Watkins's desire for individuals of this country to realise the beauty of Māori and Pacific objects. These and other inanimate objects cover the studios from floor to ceiling. They do not normally belong together but with the 'true artist's touch' a sense of harmony is created in these opulent interiors. ${ }^{5}$ This clearly was a local adaptation of an international artistic philosophy which favoured beautiful objects from ancient cultures.

Informed by the wider global movement of Aestheticism, Nerli, Nairn, and Goldie were familiar with the 'cult of beauty' culture in Europe. As I have shown, to group these artists under the term Aestheticism has very little to do with whether they collaborated, socialised or shared stylistic similarities. What unites them is a belief in 'the power of being deeply moved by the presence of beautiful objects'. 6 This is the thread which connects all of the artists and patrons referred to in this project. Aestheticism was one of the first international movements to ar rive in New Zealand

\footnotetext{
5 Singer, 'Mr C. F. Goldie and his Pictures', 10.

6 Pater, The Renaissance, xii.
} 
and should be acknowledged more substantively in literature based on our national history. The 'wilful borrowings' of artistic traditions, such as the call to worship everything beautiful from our European counterparts, ultimately translated into something original and specific to New Zealand. 


\section{LIST OF PLATES}

1 Alexander de Maus, Nerli and Hutton in front of Phryne, c. 1889-90.

2 James M. Nairn, Sun and Moon-AJapanese Landscape, 1888.

3 Unknown, Charles F. Goldie in his Studio, 1900.

$4 \quad$ J. Hendry, Photograph of J. M. Nairn, 1897.

5 'Mr Goldie at Work on The Child Christ Before the Elders', c. 1900.

6 Unknown, The Sketch Club, Christchurch, c. 1906.

$7 \quad$ G. P. Nerli, The Sitting, 1889.

8 Guy Morris, J. M. Nairn and G. P. Nerli in Dunedin, 1896.

9 Nairn's West Regent Street from Glasgow Art Club Book, 1885.

10 Unknown, Undated Photograph of Nairn in his Glasgow studio.

11 John Lavery, Hokusai and the Butterfly, 1889.

12 James M. Nairn, Portrait of Archibald Nairn, c. 1884.

13 James McNeill Whistler, Blue and Silver: Screen, 1871-72.

14 James M. Nairn, Four Seasons, c. 1888.

15 George Frederic Watts, The Head of Alfred, Lord Tennyson, 1863-64.

16 Unknown, Nairn in his Wellington Studio, mid-1890s.

17 Alcorn Family Album, Nairn's Drawing class, 1904.

18 James Kilgour, Dunedin School of Art, 1891.

19 The Fields' invitation to the Wellington Art Club Exhibition, 1893.

20 Mabel Hill's invitation to the Wellington Art Club Exhibition, 1893. 
21 Charles Conder, The 9 by 5 Exhibition Catalogue Design, 1889.

22 J. M. Nairn, Wellington Art Club Exhibition Catalogue Design, 1894.

23 Unknown, Wellington Art Club Second Annual Exhibition, 1894.

24 Alexander de Maus, E. C. Reynolds and Co. Stall, 1889-90.

25 Alexander de Maus, Theomin's Dresden Piano Stall, 1889-90.

26 Photograph of D. Scott's glass panels at 58 Royal Terrace, Dunedin.

27 Unknown, Students with Bouguereau at the Académie Julian, 1897.

28 Unknown, 'Some Auckland Studios', New Zealand Graphic, 1901.

29 Unknown, Turnbull and his Friends at Elibank, Wellington, 1890.

30 Detail of Charles F. Goldie in his Studio, 1900 (see plate 3).

31 Detail of Charles F. Goldie in his Studio, 1900 (see plate 3).

32 Detail of Charles F. Goldie in his Studio, 1900 (see plate 3).

33 Charles F. Goldie, Study of a Still Life, c. 1890.

34 Henri Toulouse-Lautrec, Divan Japonais, 1892-93.

35 Unknown, Photograph of Goldie’s Studio, c. 1900.

36 Unknown, Goldie in his Studio, Hobson's Buildings, c. 1900.

37 Unknown, Undated Photograph of Kamariera Te Wharepapa and Visitor.

38 'The New Zealand Artist', New Zealand Graphic, 1902.

39 Charles F. Goldie, Sorrowful Moments, c. 1900.

40 William-Adolphe Bouguereau, Irène, 1897.

41 Mr A. H. O’Keeffe in his Dunedin studio, 1909.

42 Detail of James M. Nairn's 'Decorative Art' in Otago Witness, 1890. 


\section{PLATES}

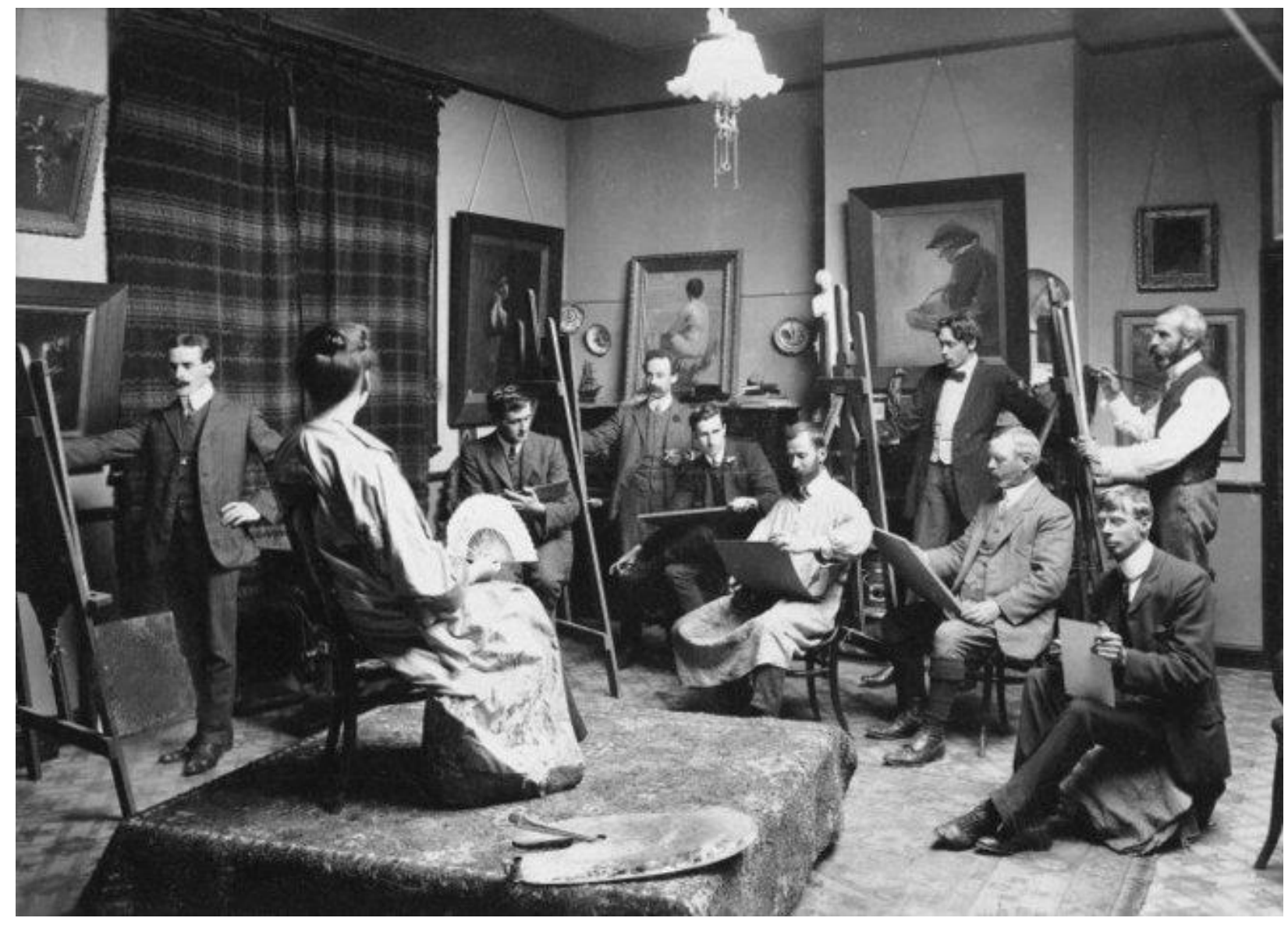

Plate 6: The Sketch Club, c. 1906 (Wellington: ATL, Ref. PAColl-5374-2). From left: Cecil Fletcher Kelly, Leonard Hampden Booth, Edwin Bartley, A. K. Henderson, Sydney Lough Thompson, Raymond Francis McIntyre, William Menzies Gibb, Alfred Wilson Walsh, and Charles E. Bickerton. 


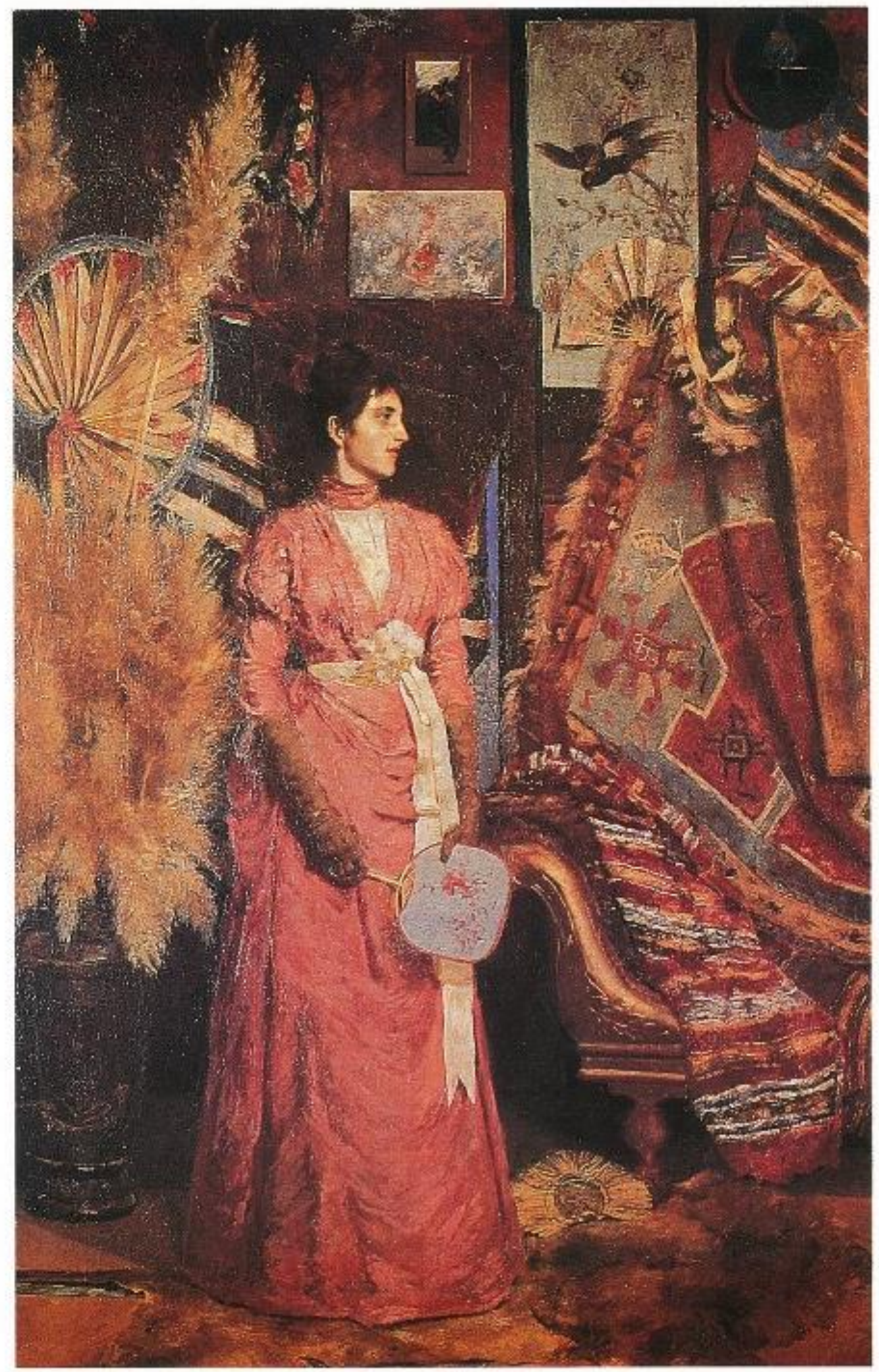

Plate 7: Girolamo Pieri Nerli, The Sitting, 1889 (Brisbane: Queensland Art Gallery). 


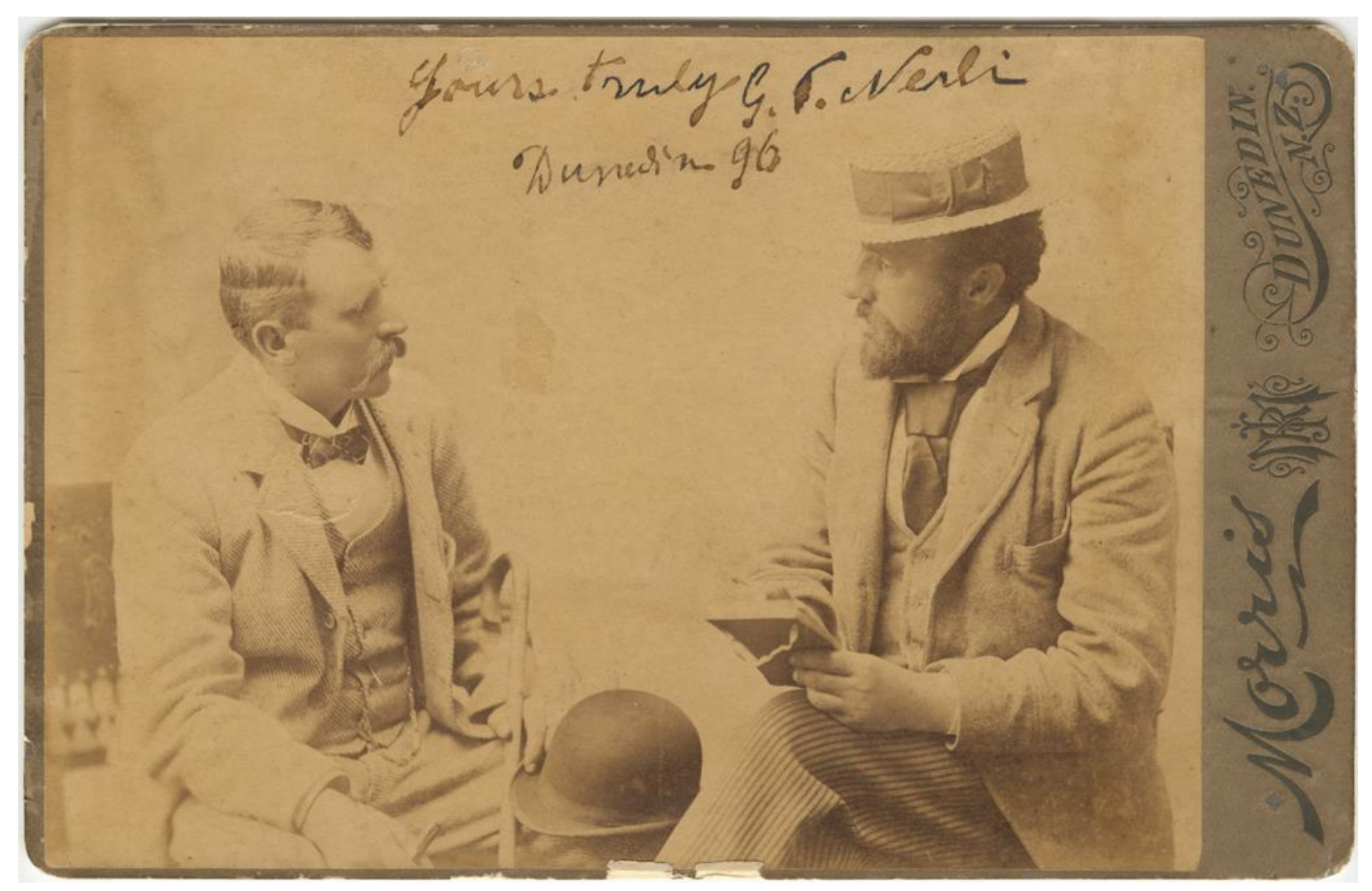

Plate 8: Guy Morris, J. M. Nairn (on left) and G. P. Nerli (on right) in conversation while meeting in Dunedin, 1896. Nerli is presumably drawing his fellow artist from life on his sketch pad. (Dunedin: Hocken Library, Ref. Box-171 MOR076). 


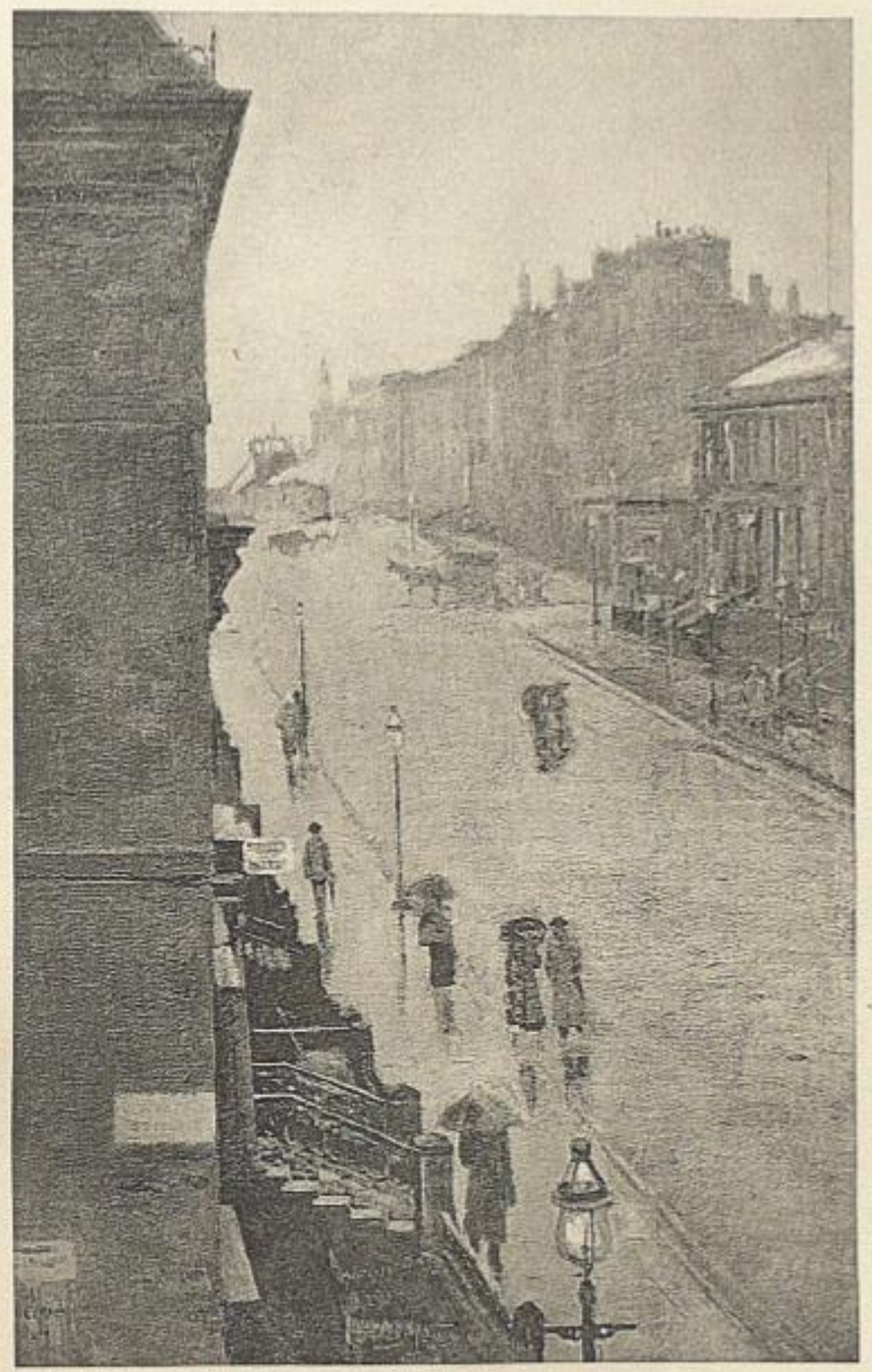

Plate 9: Untitled photogravure of an original painting by James McLauchlan Nairn, published in Glasgow Art Club Book, 1885, 176 (National Library of Scotland, Glasgow). 


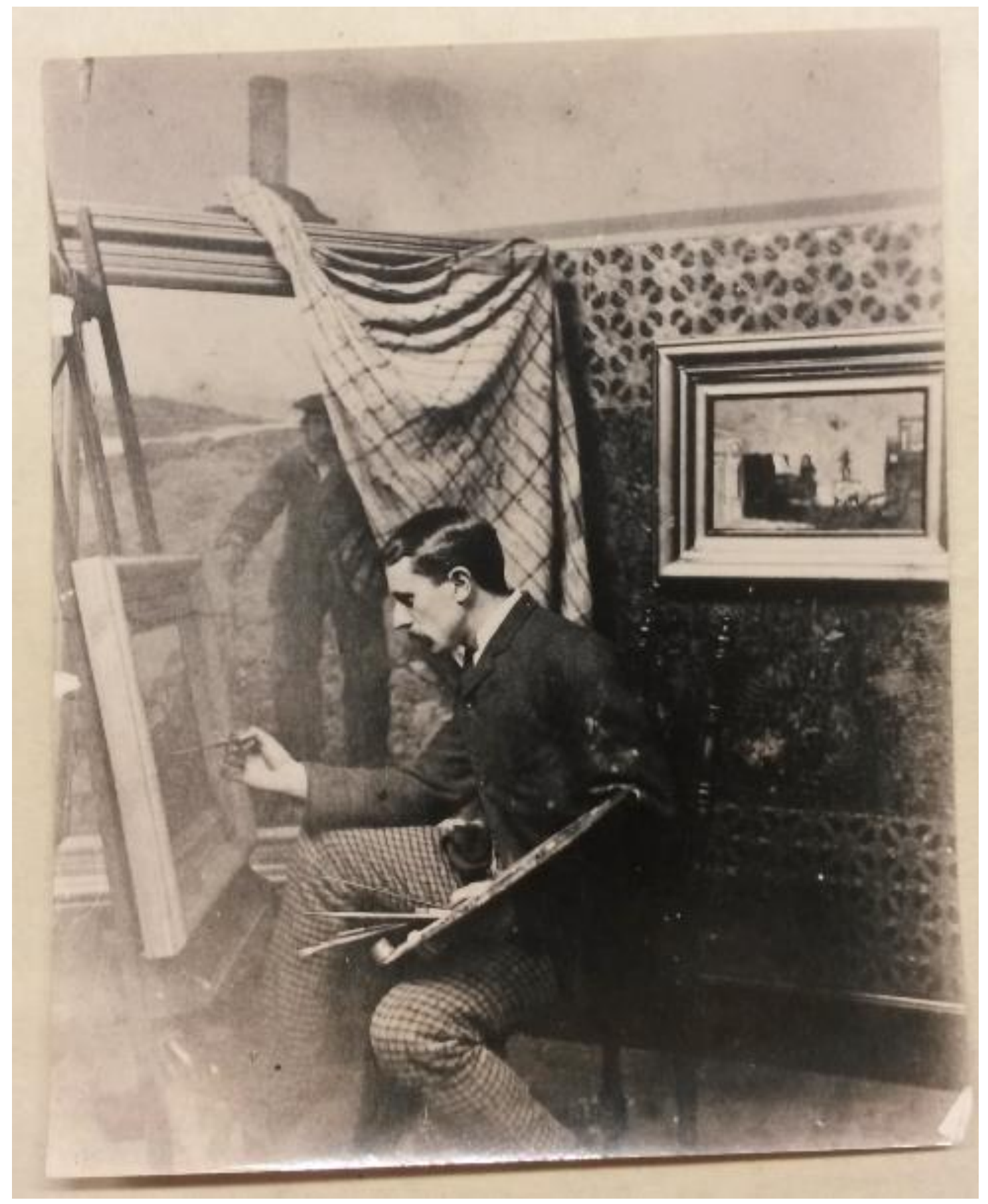

Plate 10: Undated photograph of Nairn in his Glasgow studio with Clearing the Stake-nets, Eyemouth, c. 1883 in the background with fabric draping over frame. Taken by an unknown photographer in mid-1880s. (ATL, Wellington: PAColl-6853). 


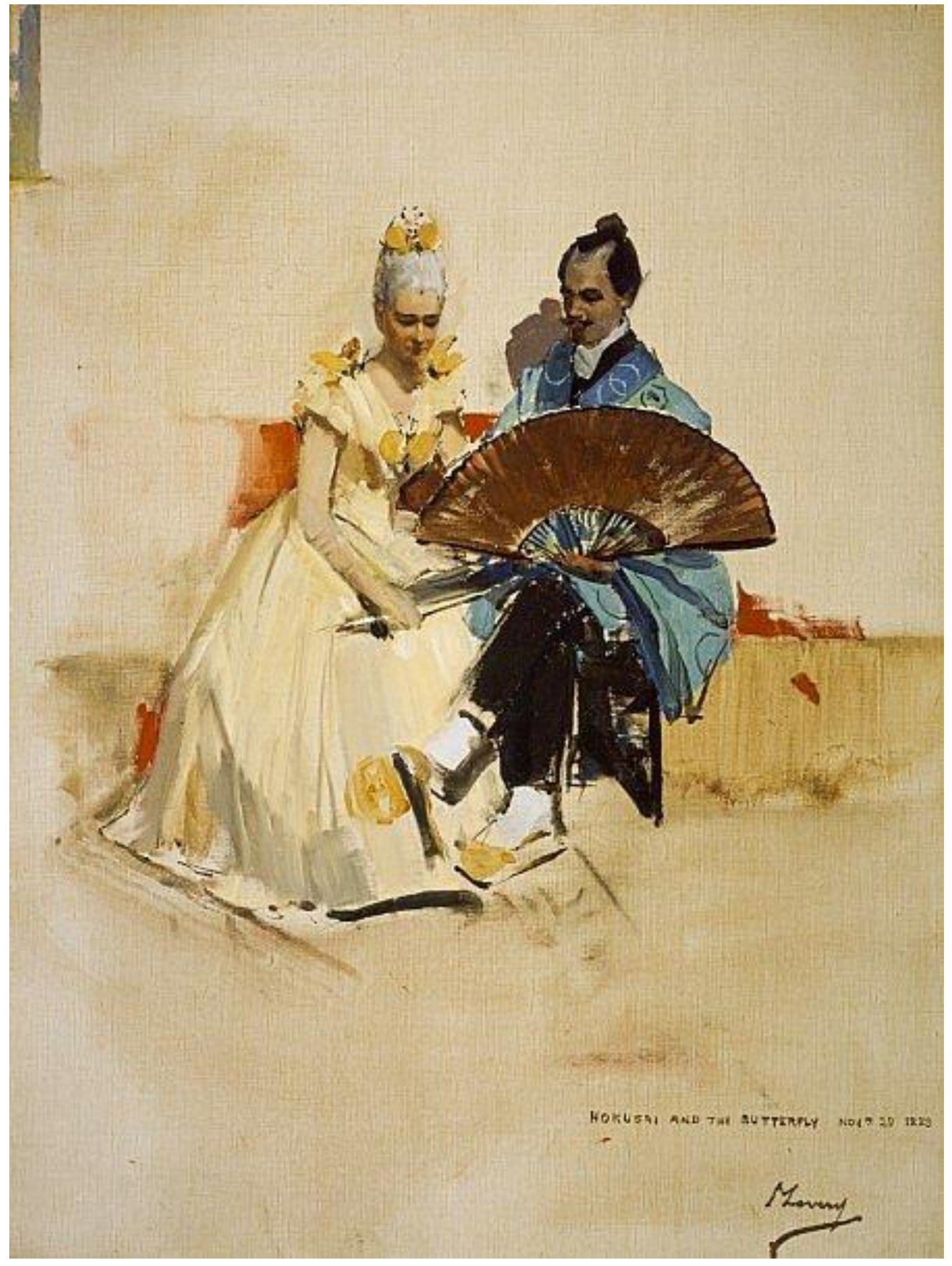

Plate 11: John Lavery, E. A. Walton with his fiancée Helen Law (Hokusai and the Butterfly), 1889, watercolour on paper, (National Galleries of Scotland, Edinburgh). 


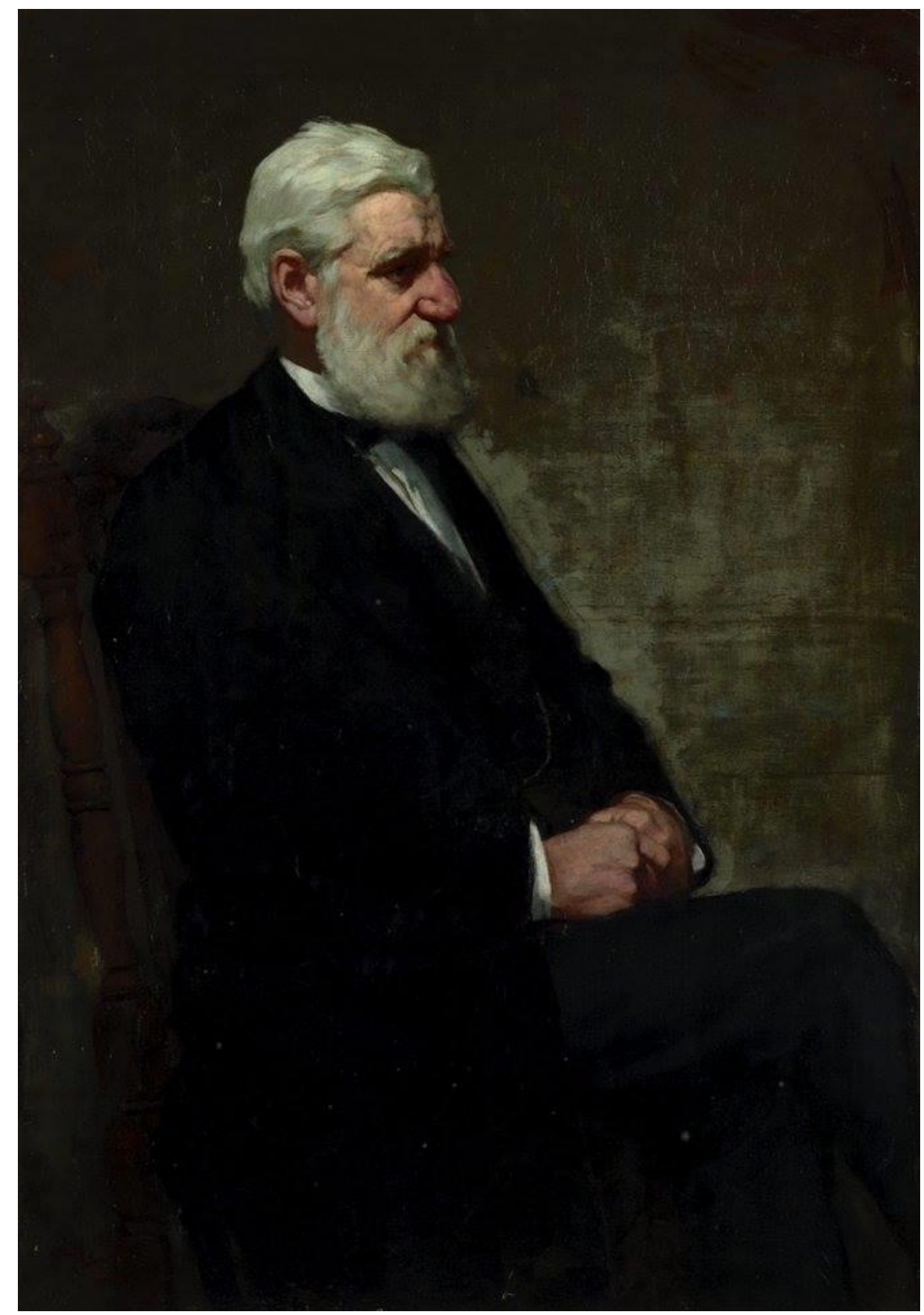

Plate 12: James M. Nairn, Portrait of Archibald Nairn, 1884 (Museum of New Zealand Te Papa Tongarewa, Wellington). 

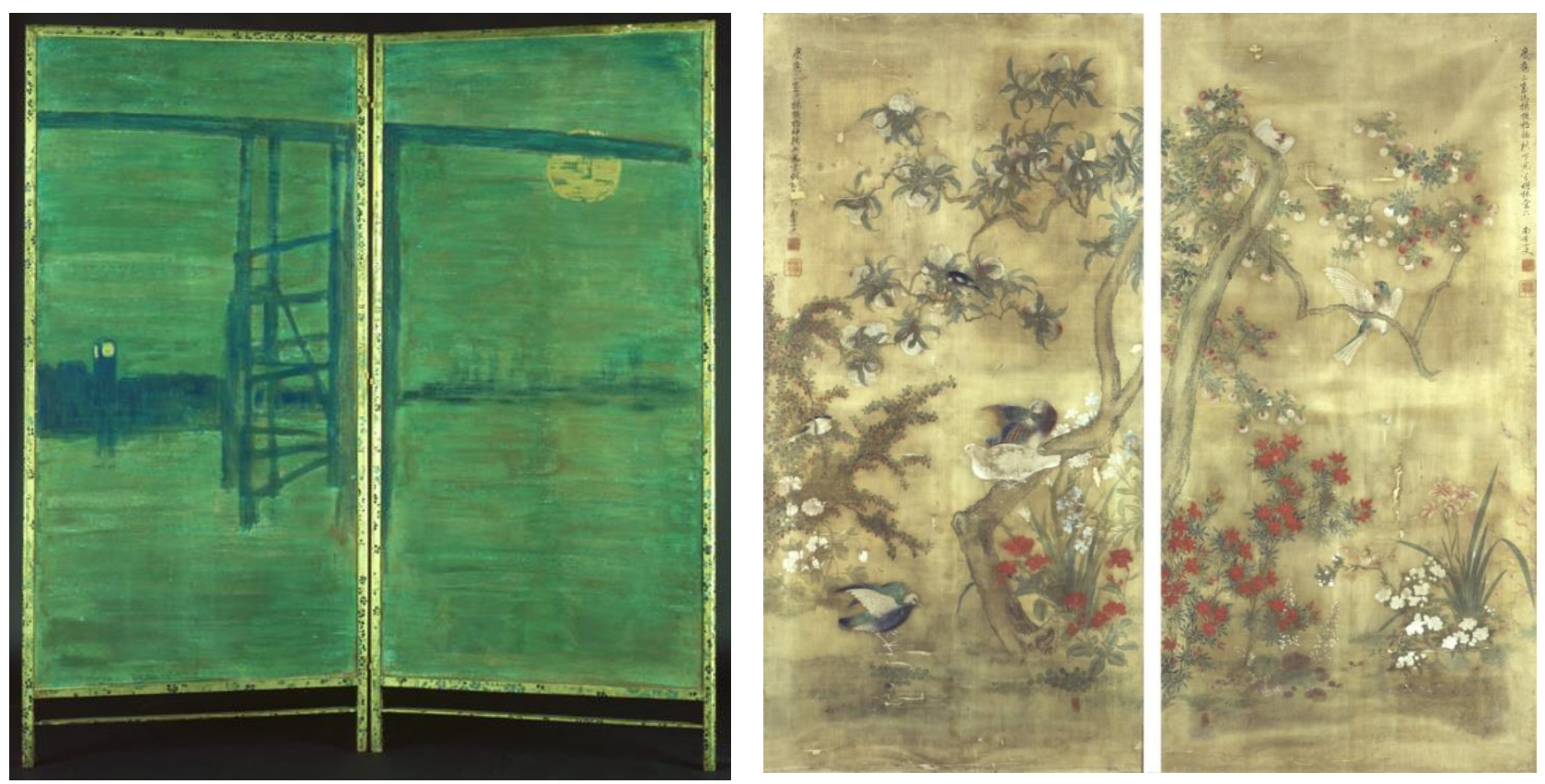

Plate 13: (upper left) James McNeill Whistler, Blue and Silver: Screen, with Old Battersea Bridge, 1871-72, distemper and gold paint on brown paper laid on canvas stretched on back of silk, (The Hunterian Museum and Art Gallery, University of Glasgow). (Upper right) on reverse (not by Whistler) Osawa Nampo's Birds and Blossoms, Autumn, 1866-1867, oil and watercolour on silk. Screen fully opened measures 1950 x $1820 \mathrm{~mm}$.

(Below) James M. Nairn's Anglo-Japanese screen (for more details, see plate 2). Nairn's screen was clearly influenced by Whistler's promotion of oriental art and the Far East.

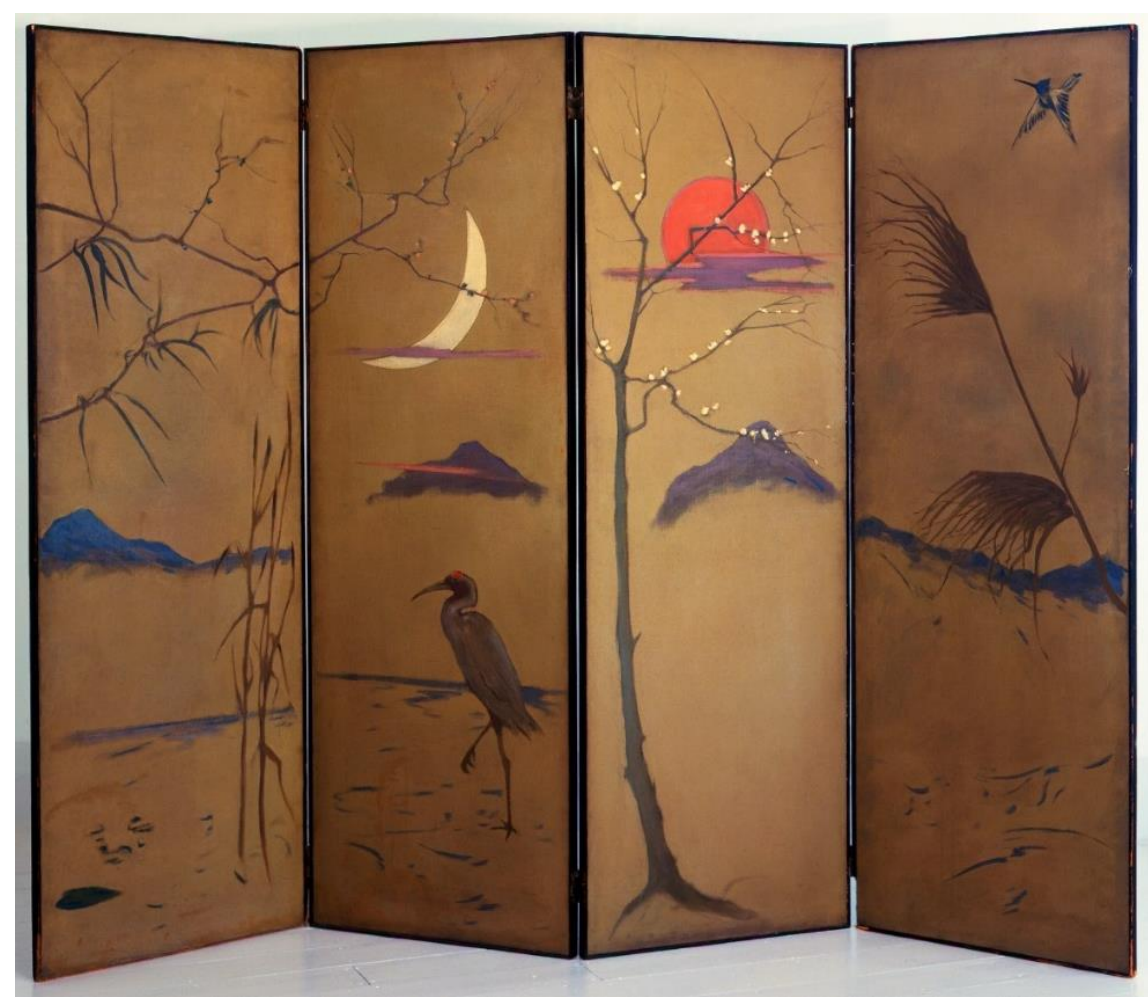




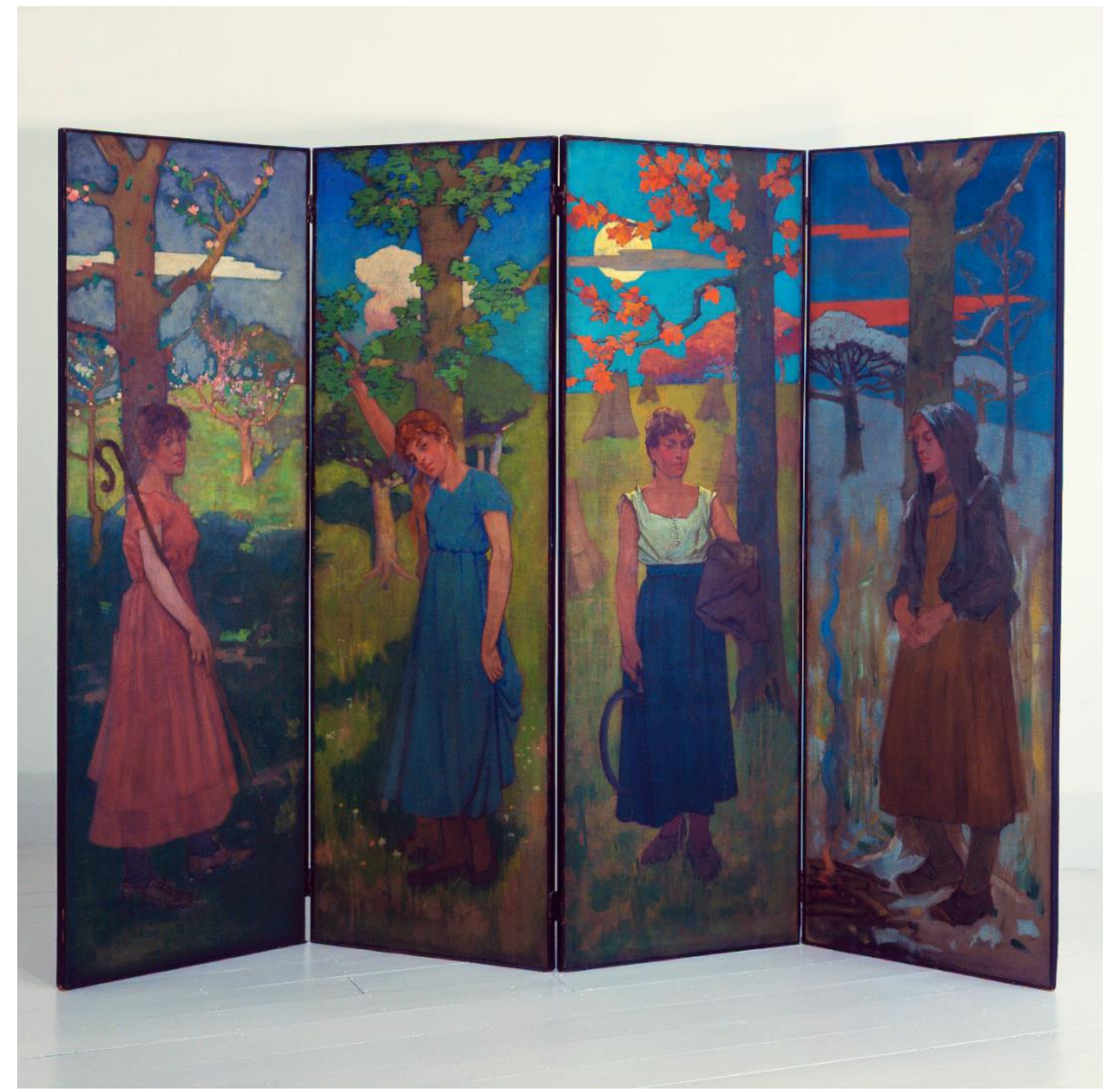

Plate 14: James McLauchlan Nairn, Four Seasons, c. 1888 (recto) screen, oil on canvas, four framed panels, each 1727 x 559 mm, (purchased 1987 by the National Art Gallery, now Museum of New Zealand Te Papa Tongarewa). 


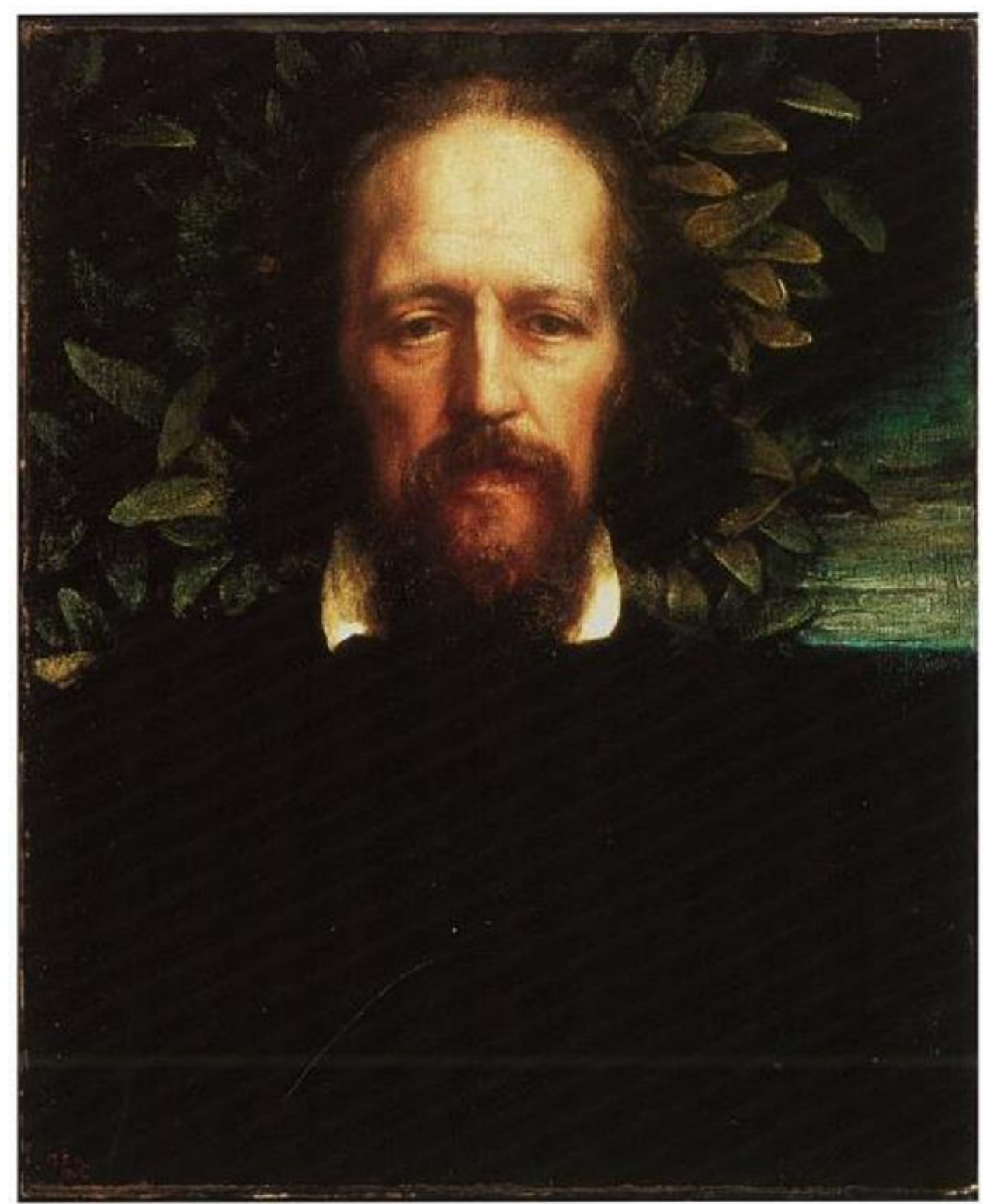

Plate 15: George Frederic Watts, The Head of Alfred, Lord Tennyson (Poet Laureate), 1863-4, oil on canvas (private collection). 


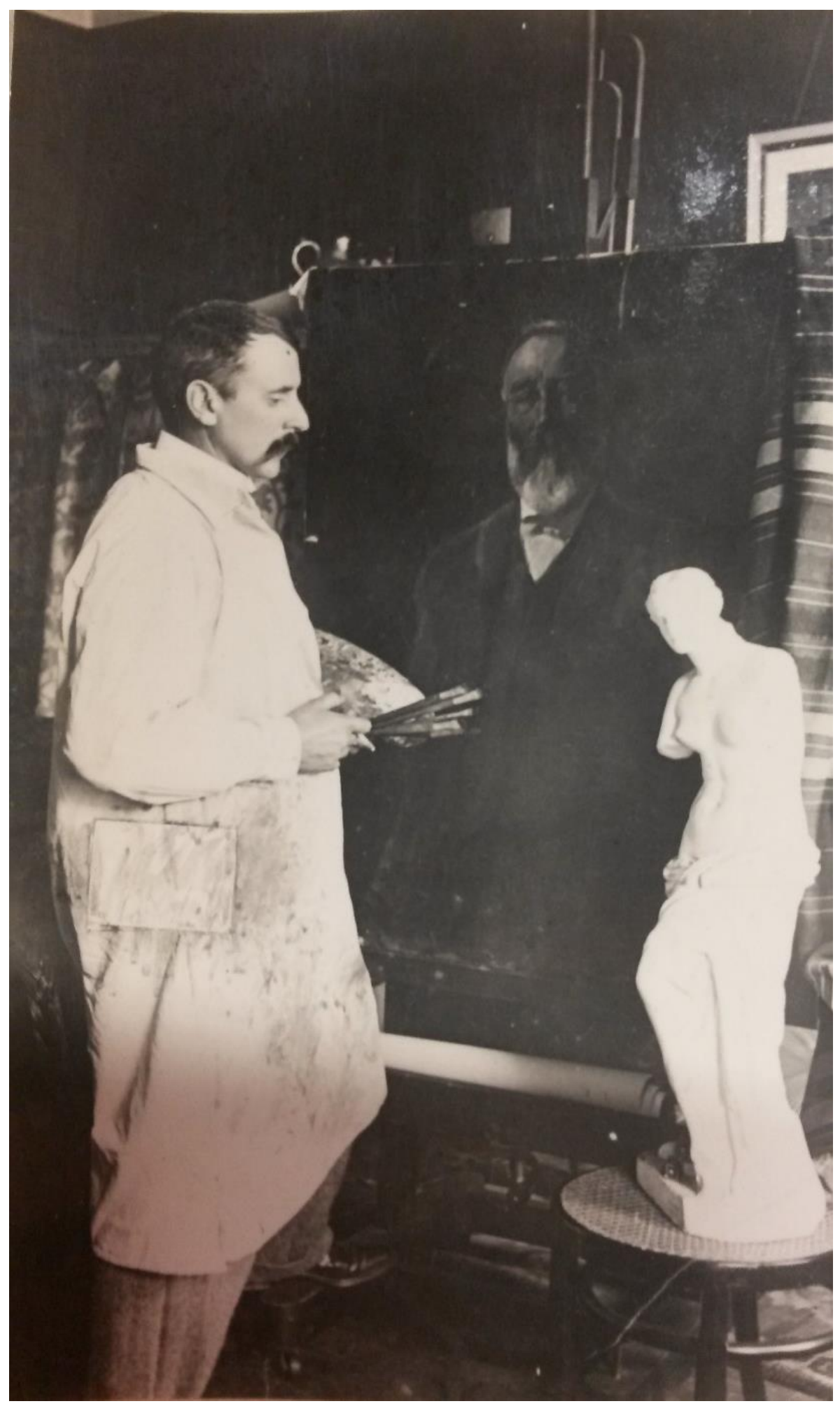

Plate 16: Unidentified photographer, Nairn in his Wellington studio, taken mid-to-late 1890s (J. M. Nairn File, Te Papa Library). 


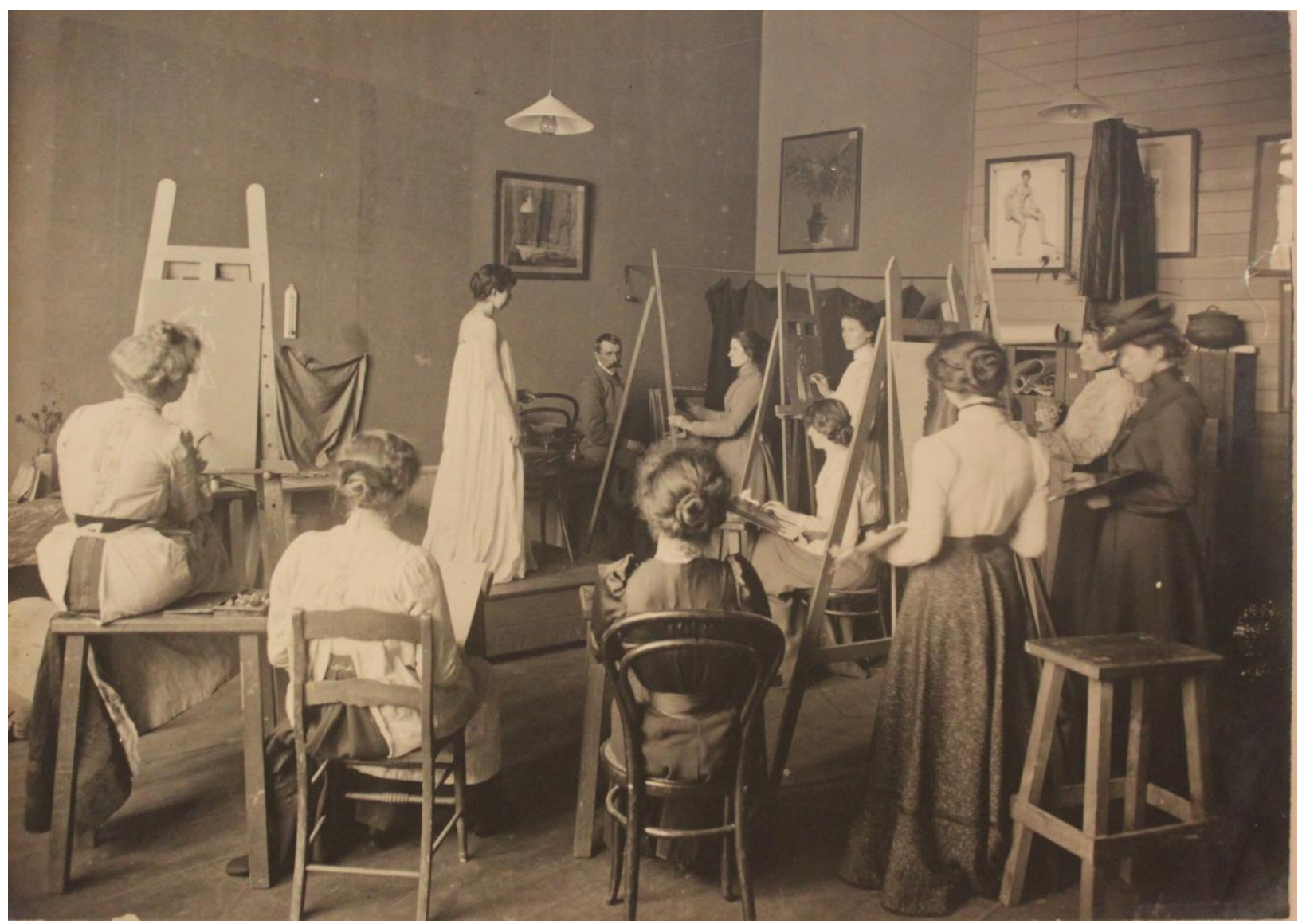

Plate 17: Nairn teaching classes at Wellington School of Design, taken only months before the artist's death in 1904 (ATL: Alcorn Family Album: Photographs of Wellington Technical School, PAColl-3016,). 


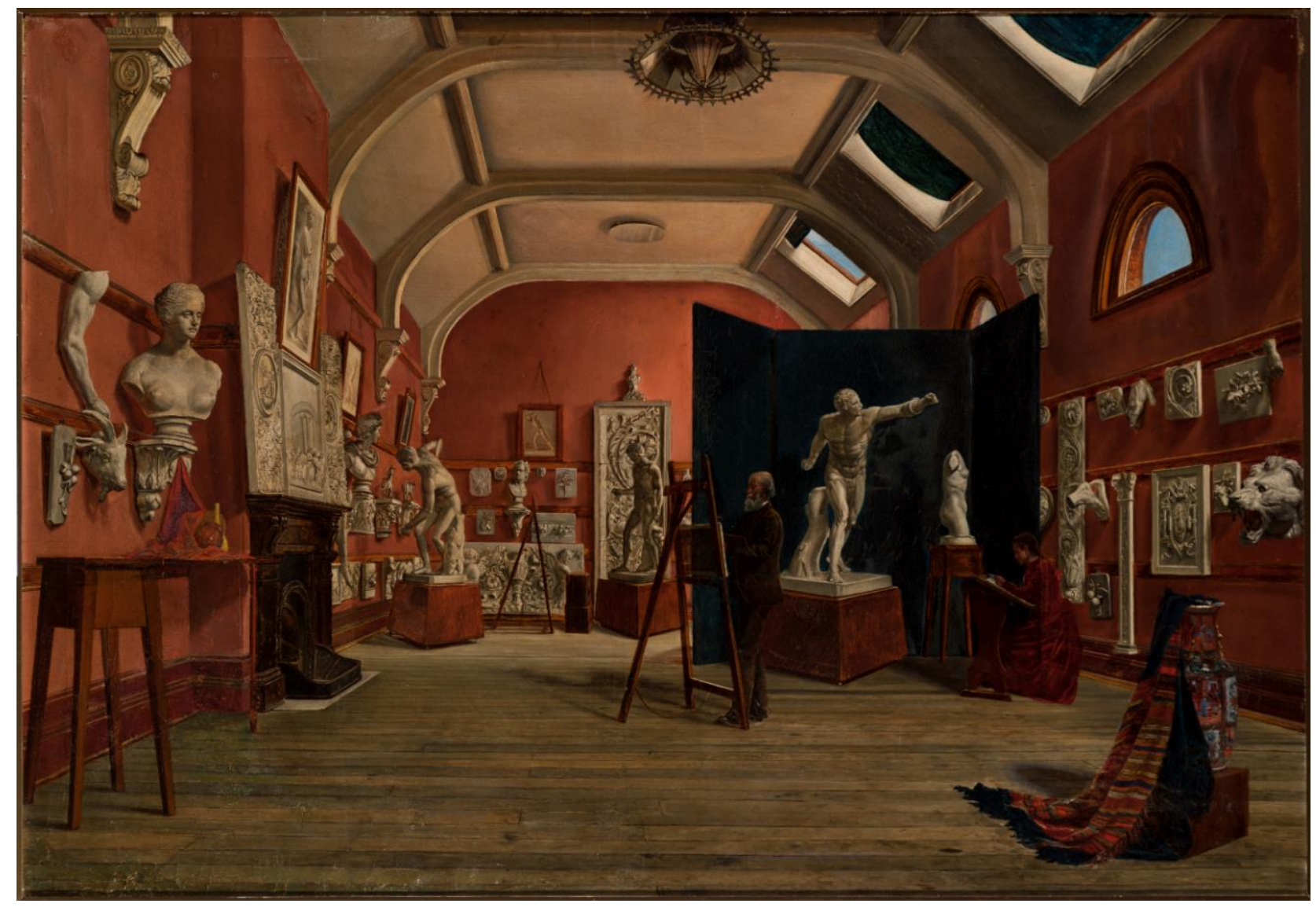

Plate 18: James Kilgour, Dunedin School of Art, 1891 (Hocken Library Pictorial Collection, Dunedin). 


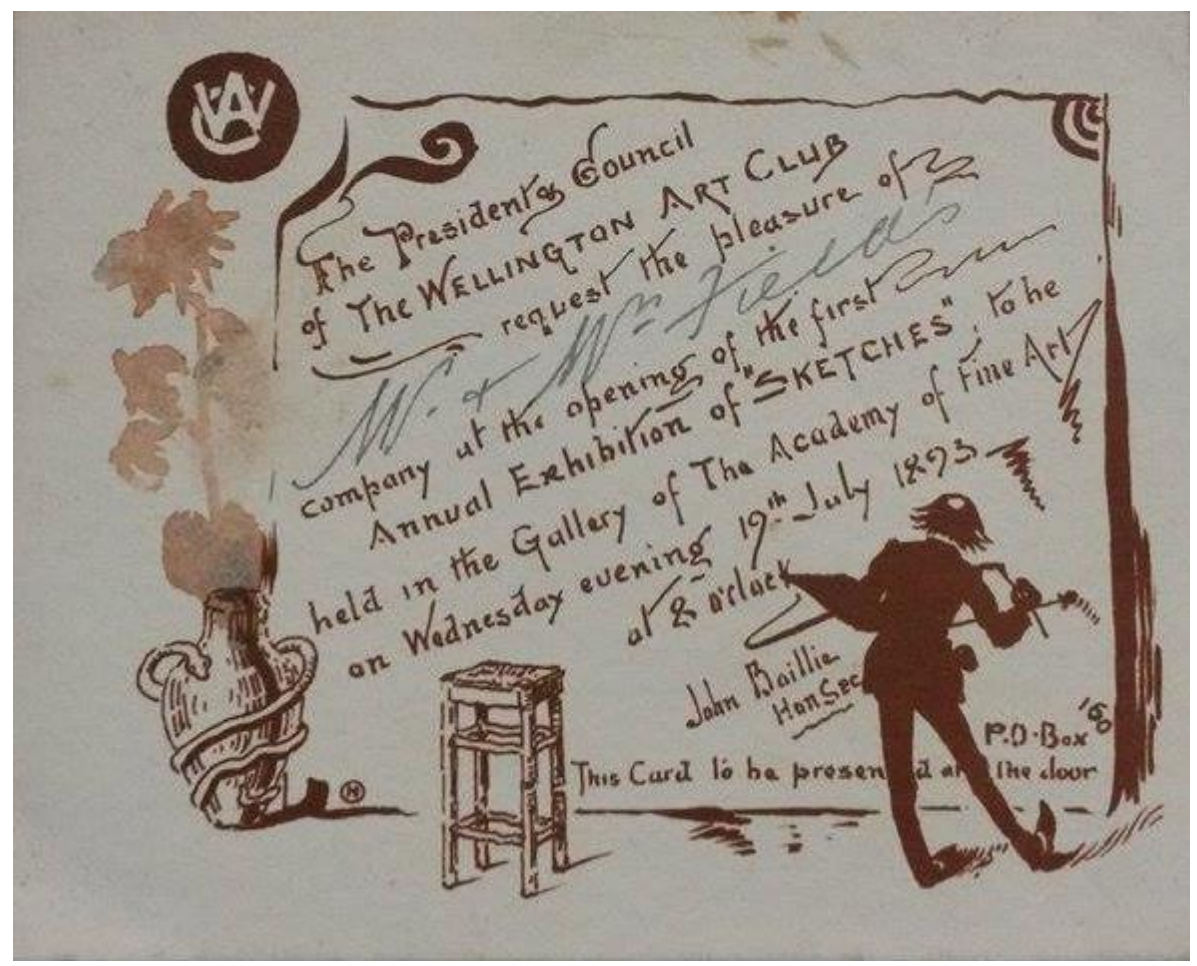

Plate 19: (Above) Invitation for Will and Isabel Field to attend the Wellington Art Club Second Annual Exhibition, 1893. 'Field and Hodgkins' Family Papers', (Wellington: ATL, MS-Papers-0113-06/1).

Plate 20: (Below) Mabel Hill's Invitation with a hand-painted watercolour of a fern in a Japanese vase, 1893, 'Hill, Mabel Papers', (Wellington: ATL, MSPapers-5581).

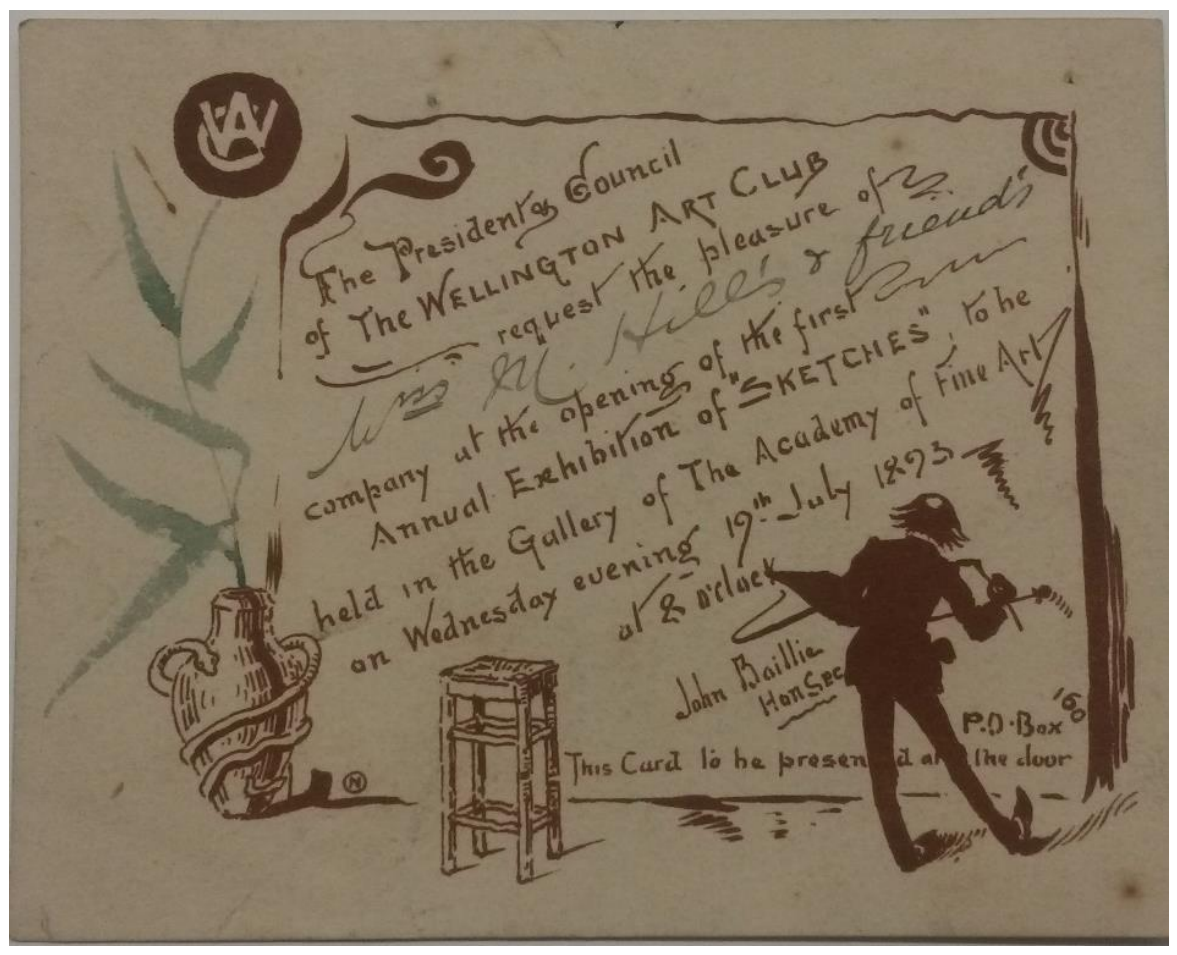




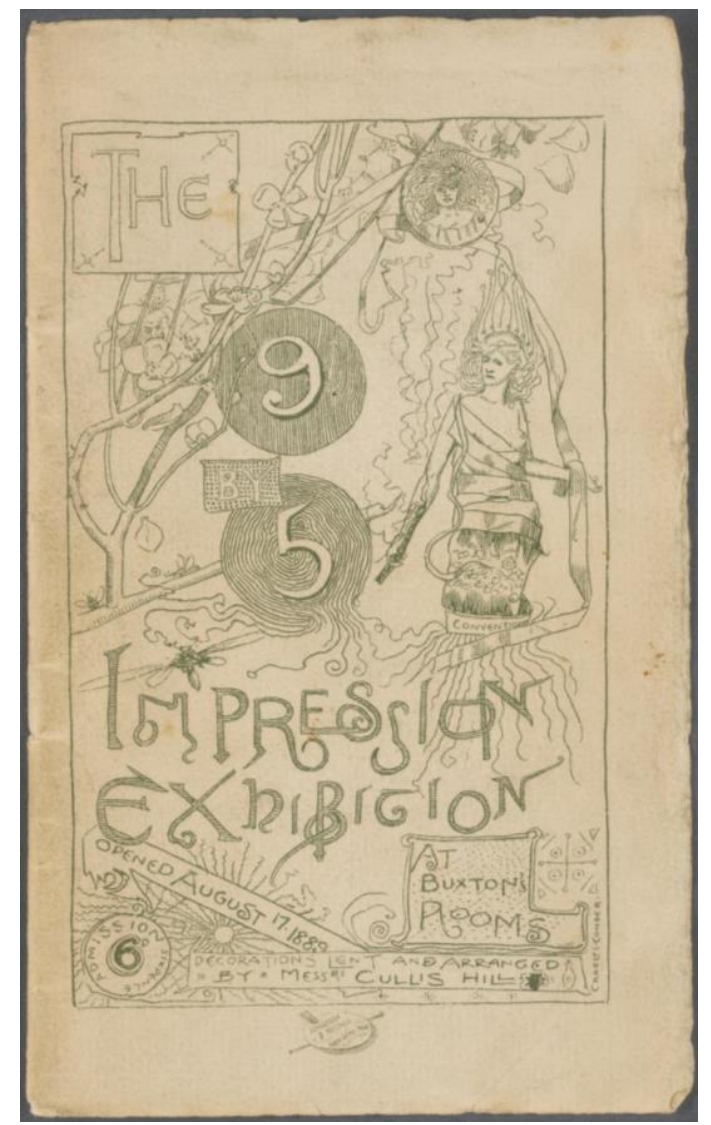

Plate 21: (Above) The 9 by 5 Exhibition, 1889. Catalogue cover designed by Charles Conder (NGV, Melbourne).

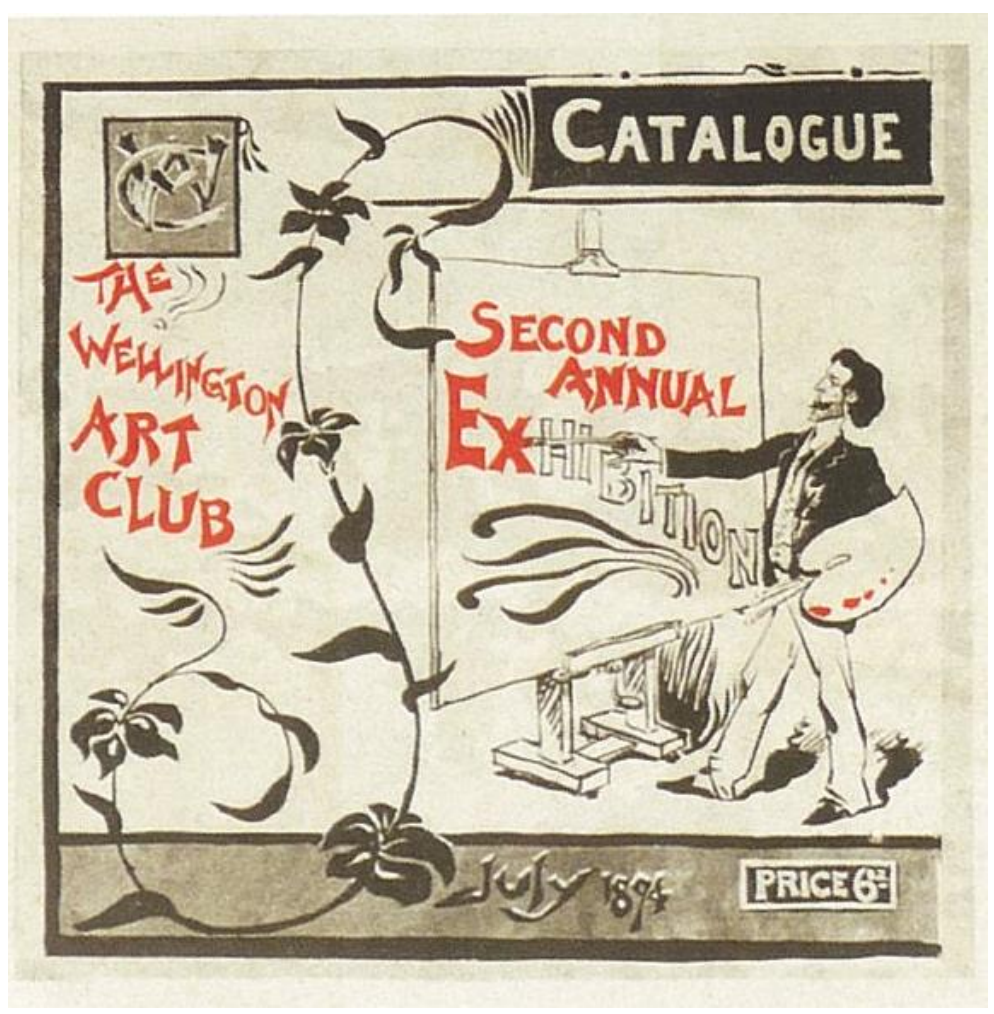

Plate 22: (Above) The Wellington Art Club's Second Annual Exhibition, July 1894. Catalogue cover designed by James M. Nairn. (Photograph courtesy of Bill Main Collection). 


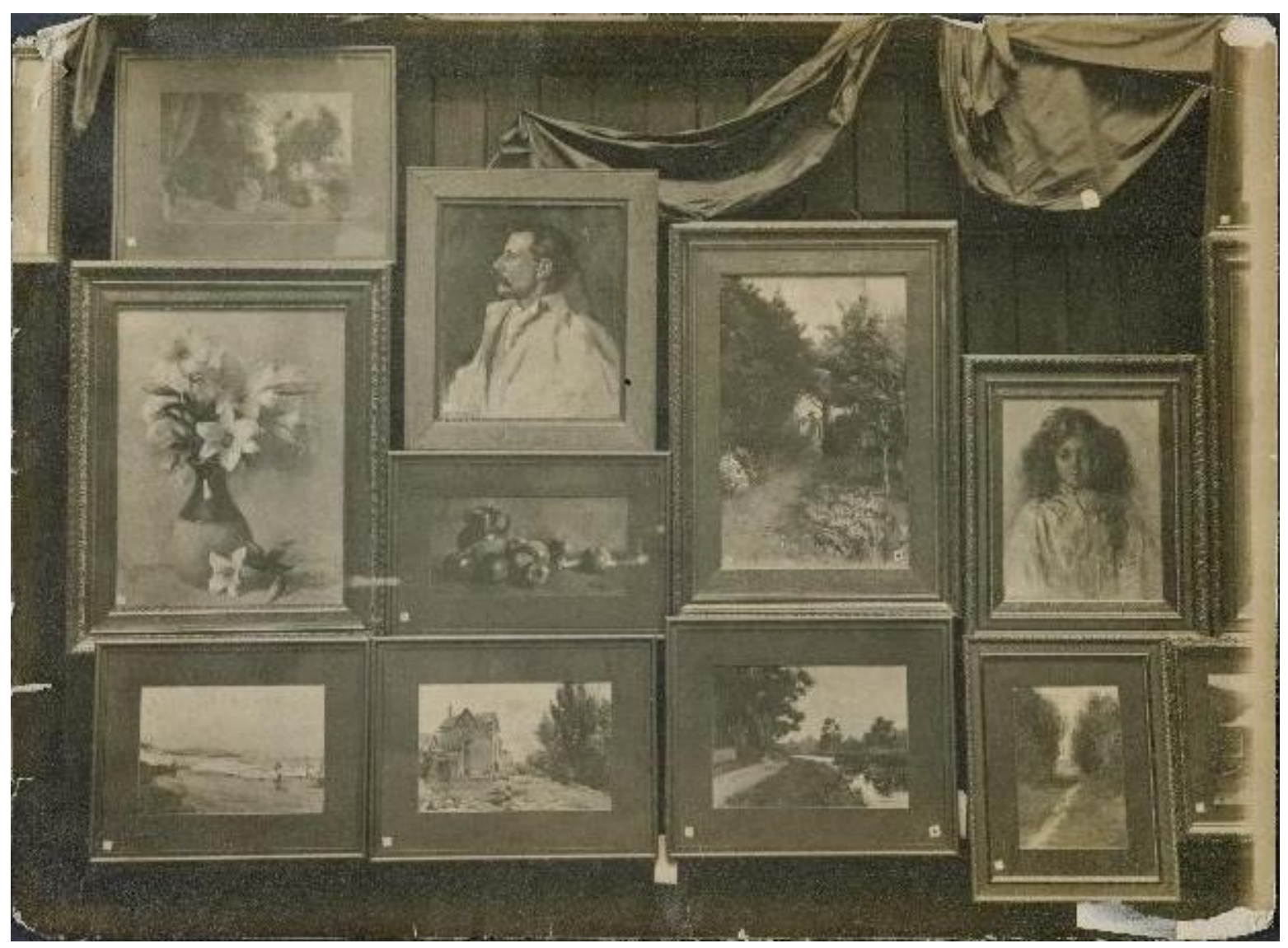

Plate 23: Unidentified photographer, Wellington Art Club's Second Annual Exhibition, 1894. (Museum of New Zealand Te Papa Tongarewa, Ref. 0.031087). Mabel Hill's Whistlerian profile portrait of Nairn is upper centre. 


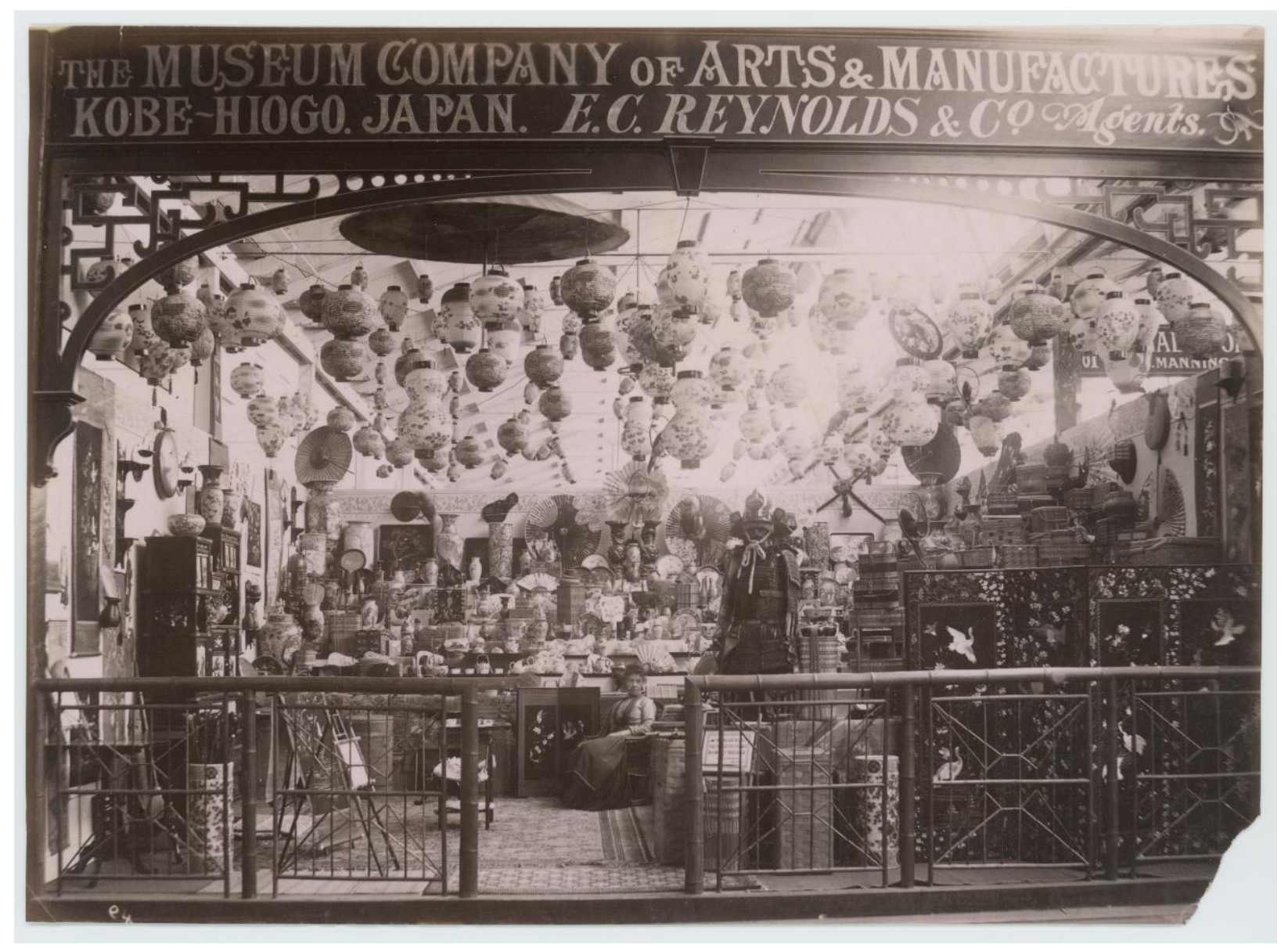

Plate 24: Alexander de Maus, E. C. Reynolds \& Co. Stall, New Zealand \& South Seas Exhibition Photograph Album, c. 1889-90, (Toitū Otago Settlers Museum: Ref. 1919.134.324). 


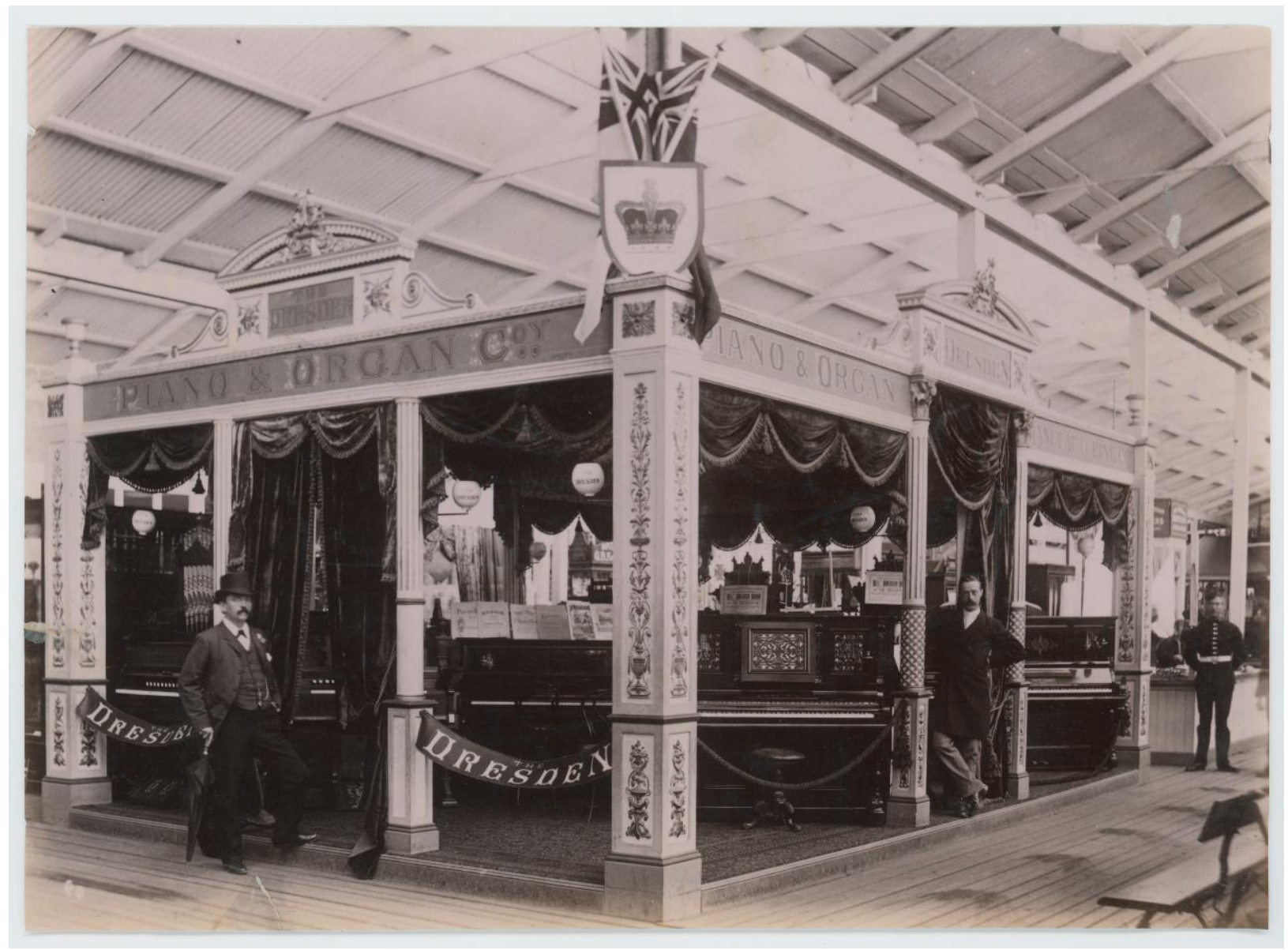

Plate 25: Alexander de Maus, Theomin's Dresden Piano \& Organ Co. Stall draped in Liberty Silks, New Zealand \& South Seas Exhibition Photograph Album, c.1889-90, (Toitū Otago Settlers Museum: Ref. 1919.134.324). 

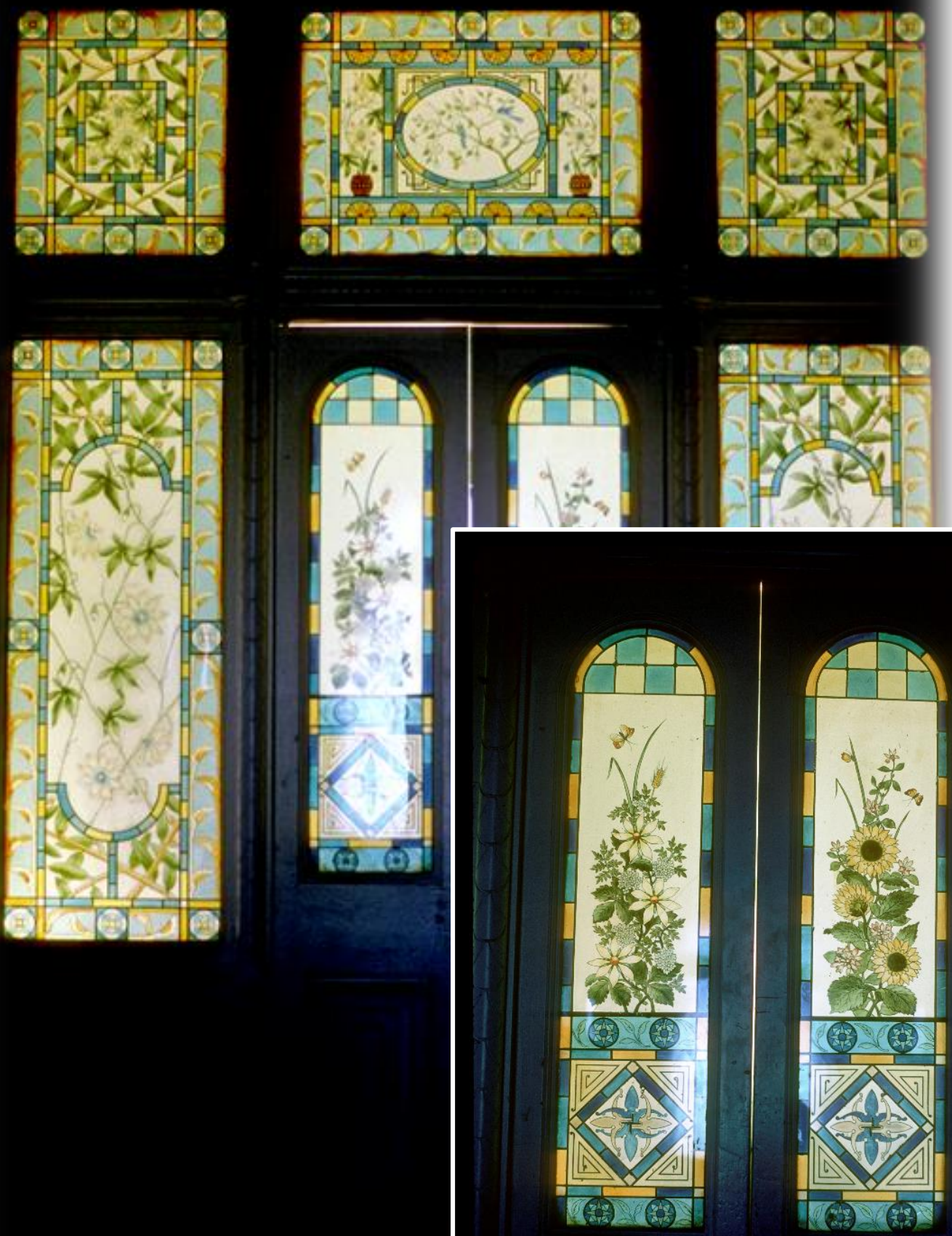

Plate 26: Glass panels by D. Scott at 58 Royal Terrace, Dunedin. [Inset] Detail of glass panels in front door with sunflowers and daises. (ATL: PA12-1433). 


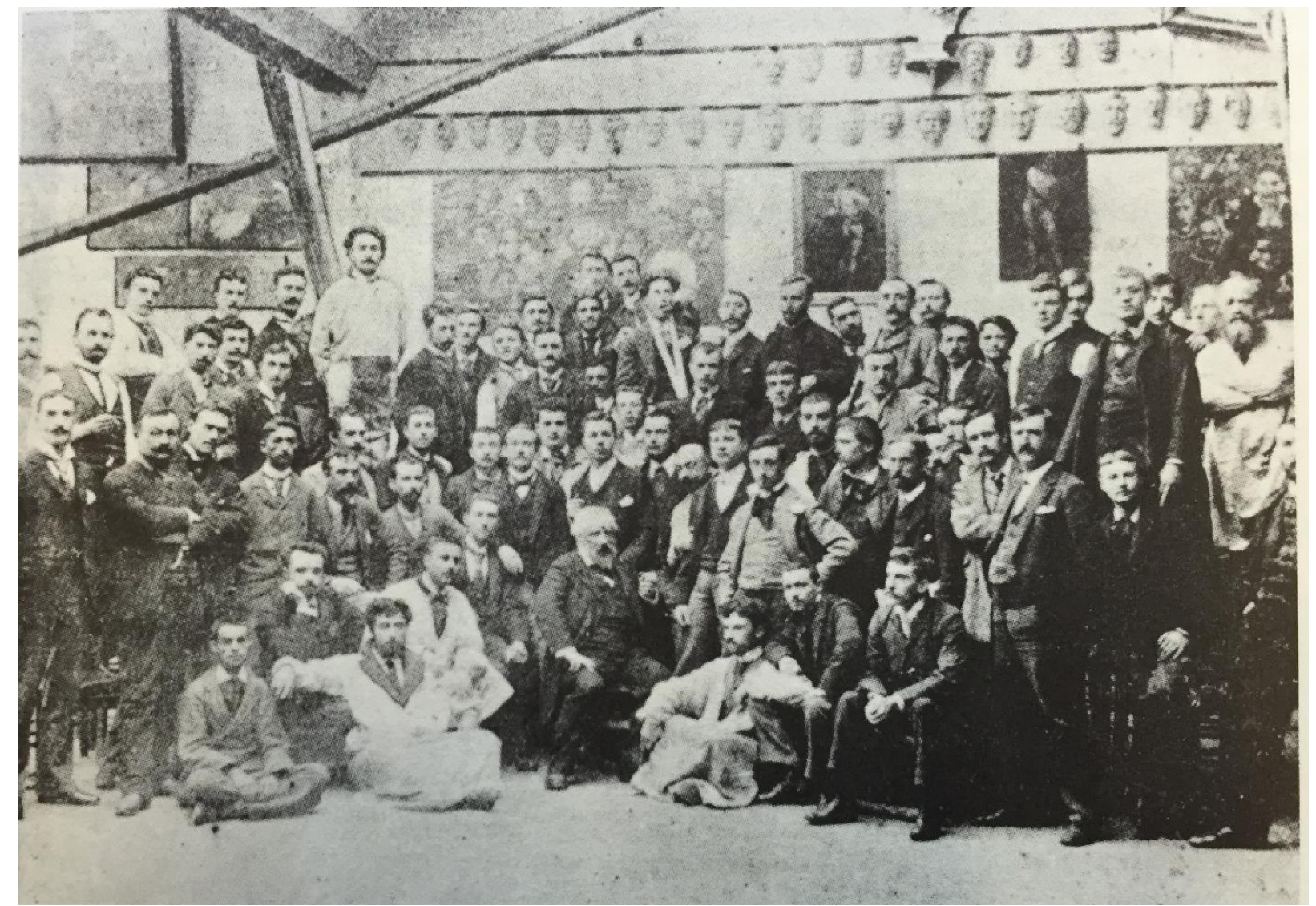

Plate 27: Unidentified photographer, Students with Bouguereau at the Académie Julian, 1897. Goldie stands in the back row, fifth from the left. Image reproduced in New Zealand Illustrated Magazine, 1 October 1901, 20. 


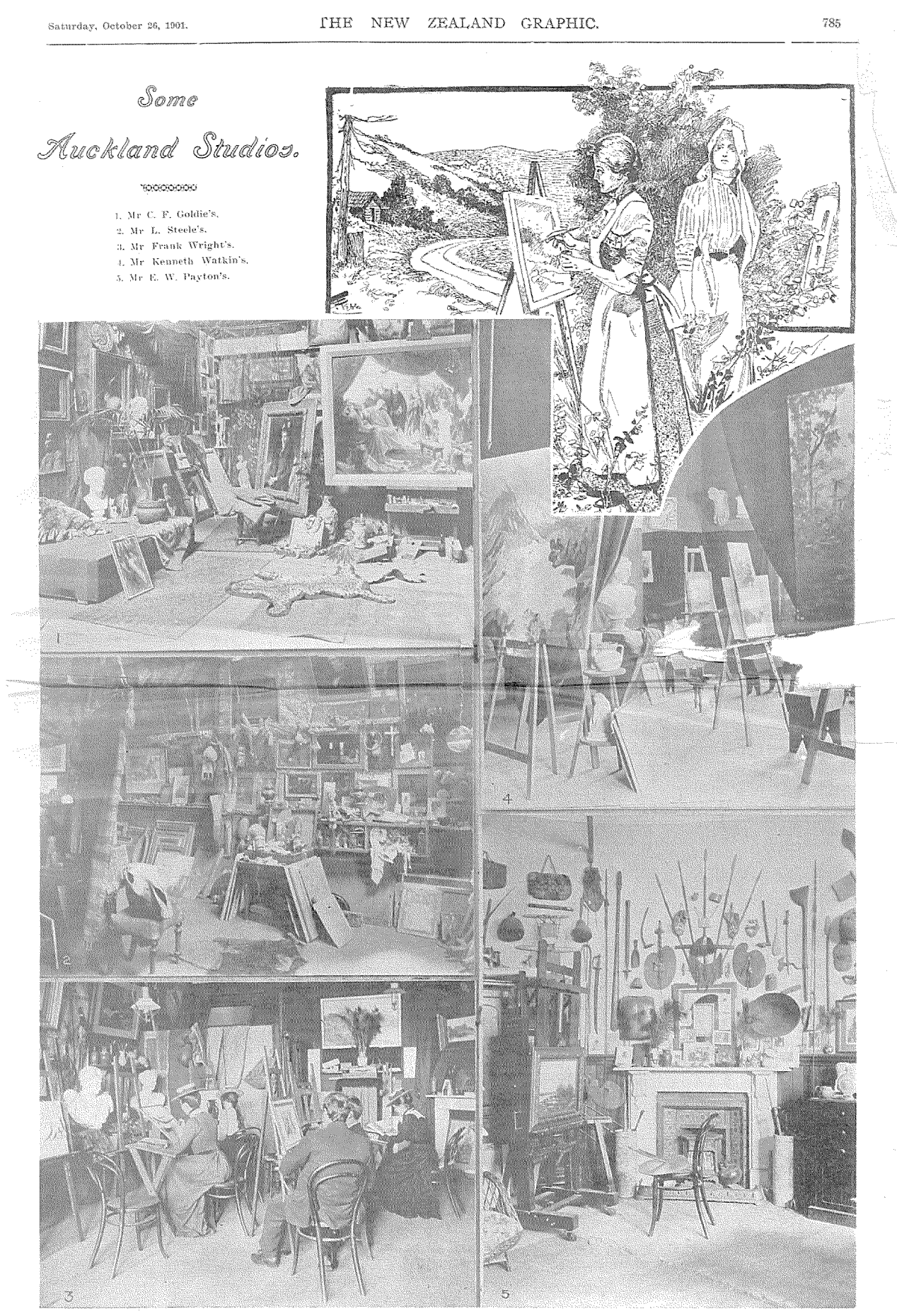

Plate 28: 'Some Auckland Studios', New Zealand Graphic, 26 October 1901, 785. 


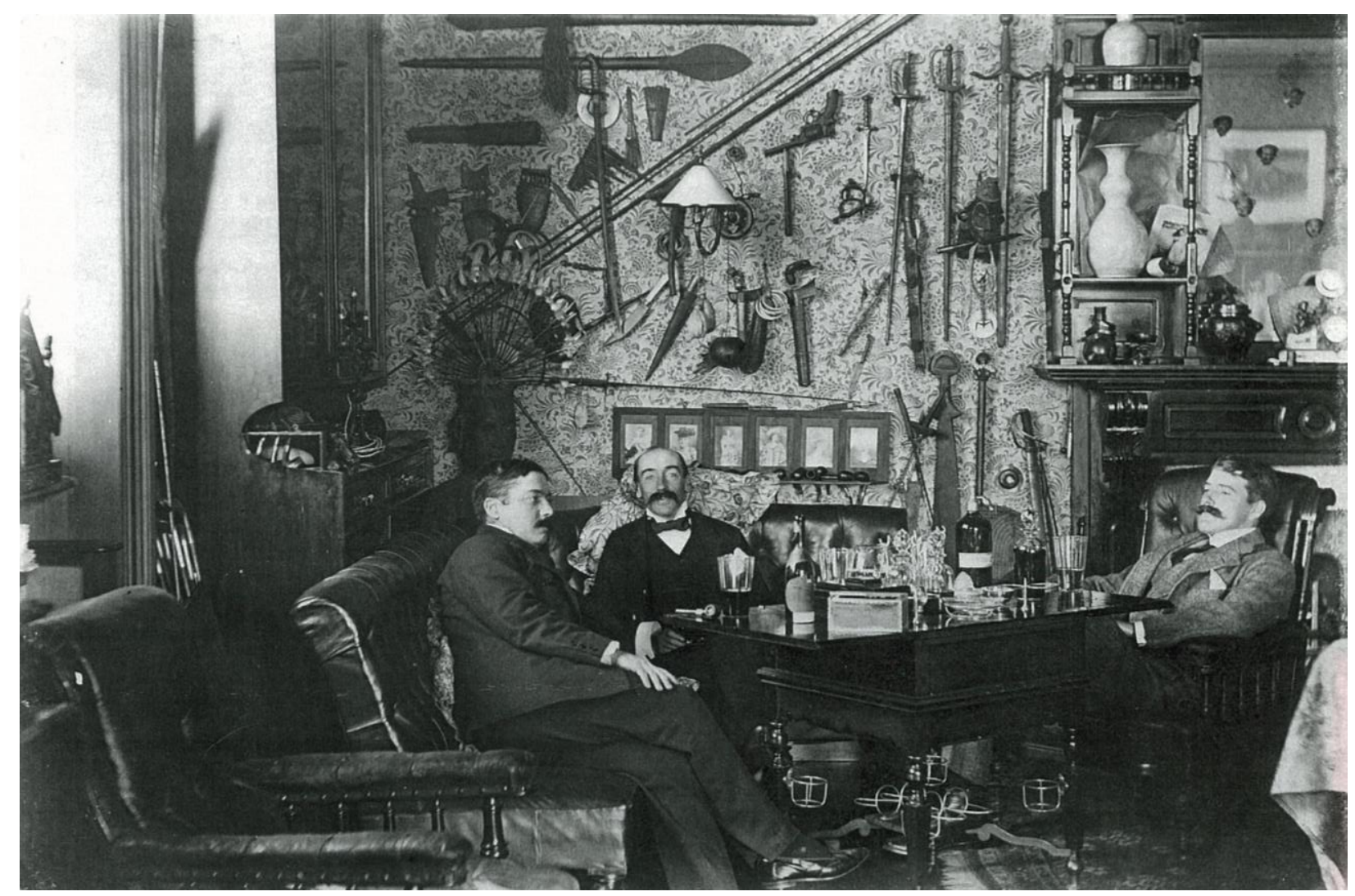

Plate 29: Unidentified Photographer, 'Robert Turnbull, E. F. Hadfield and Alexander Turnbull' at the Turnbull home, 'Elibank', c. 1890. (Wellington: ATL: 1/2-002608-F). 


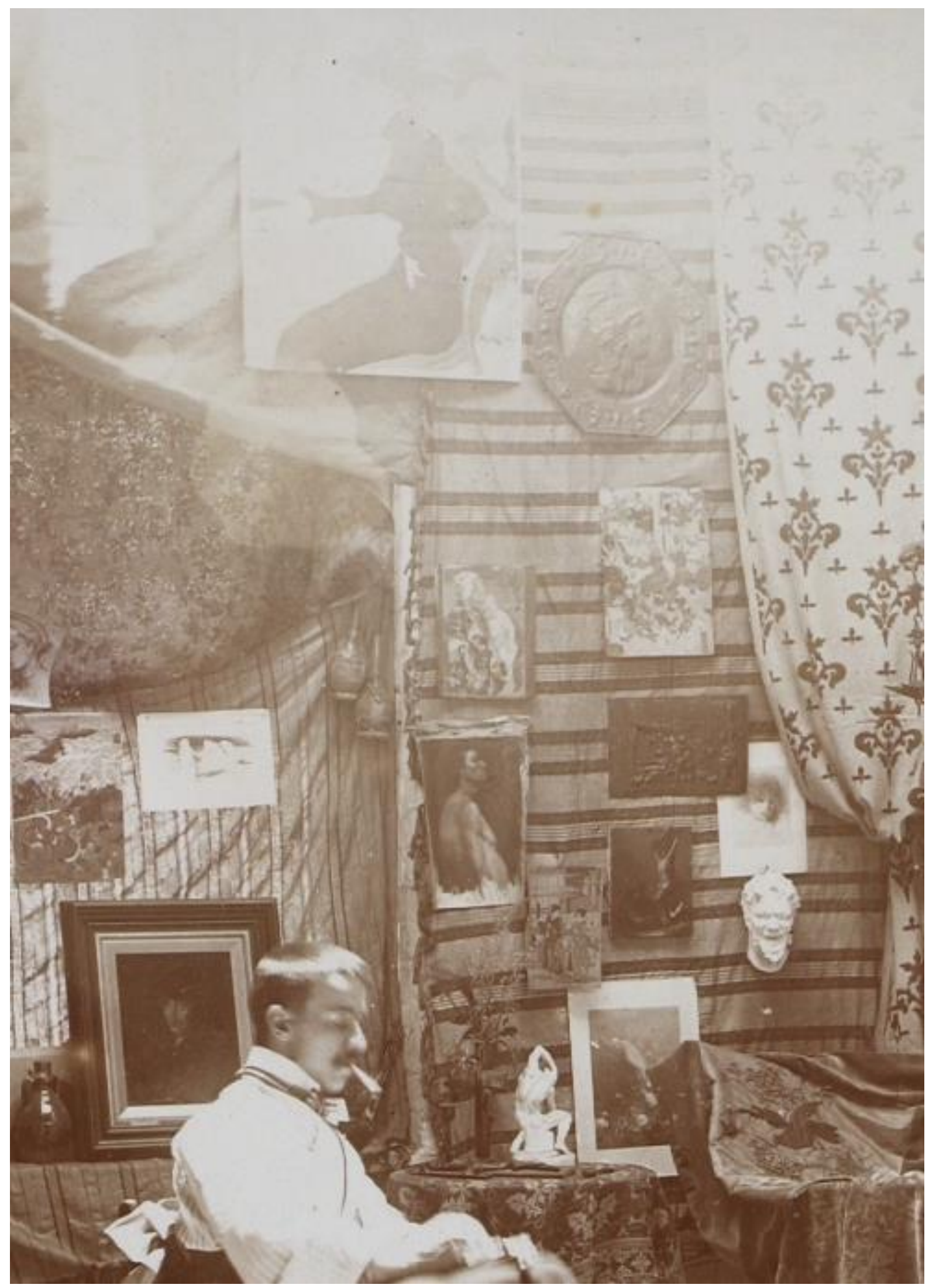

Plate 30: Detail of Plate 3. The main wall features esquisses, fabrics and antique casts collected by Goldie, who is leisurely smoking in the comfort of his studio. 


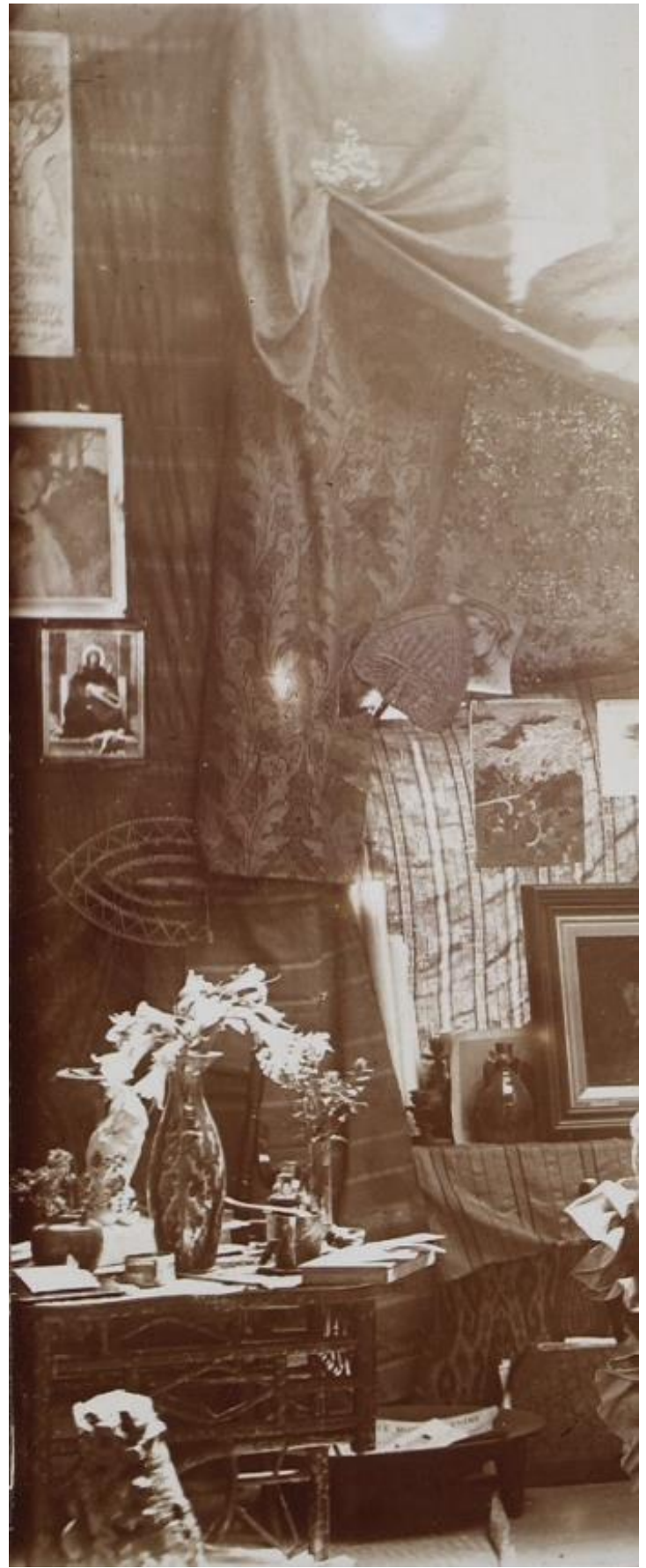

Plate 31: Detail of Plate 3. Left side of the photograph with engraving of Bouguereau's Virgin of Consolation, Pacific woven fans and traditional kava bowl on floor.

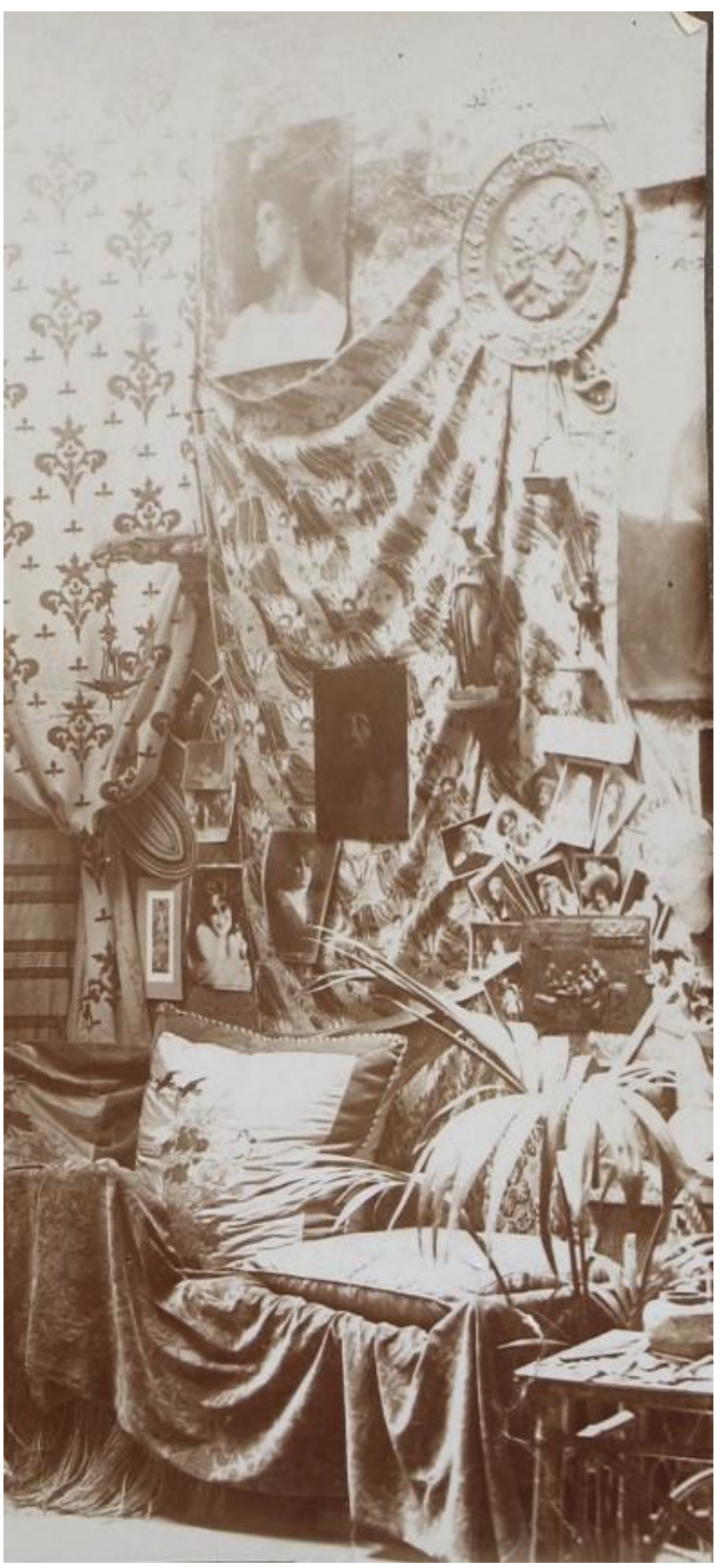

Plate 32: Detail of Plate 3. Right side of the photograph with the divan, oil sketch of Ecce Homo, Edwardian beauties and the unframed portrait in his early still life. 


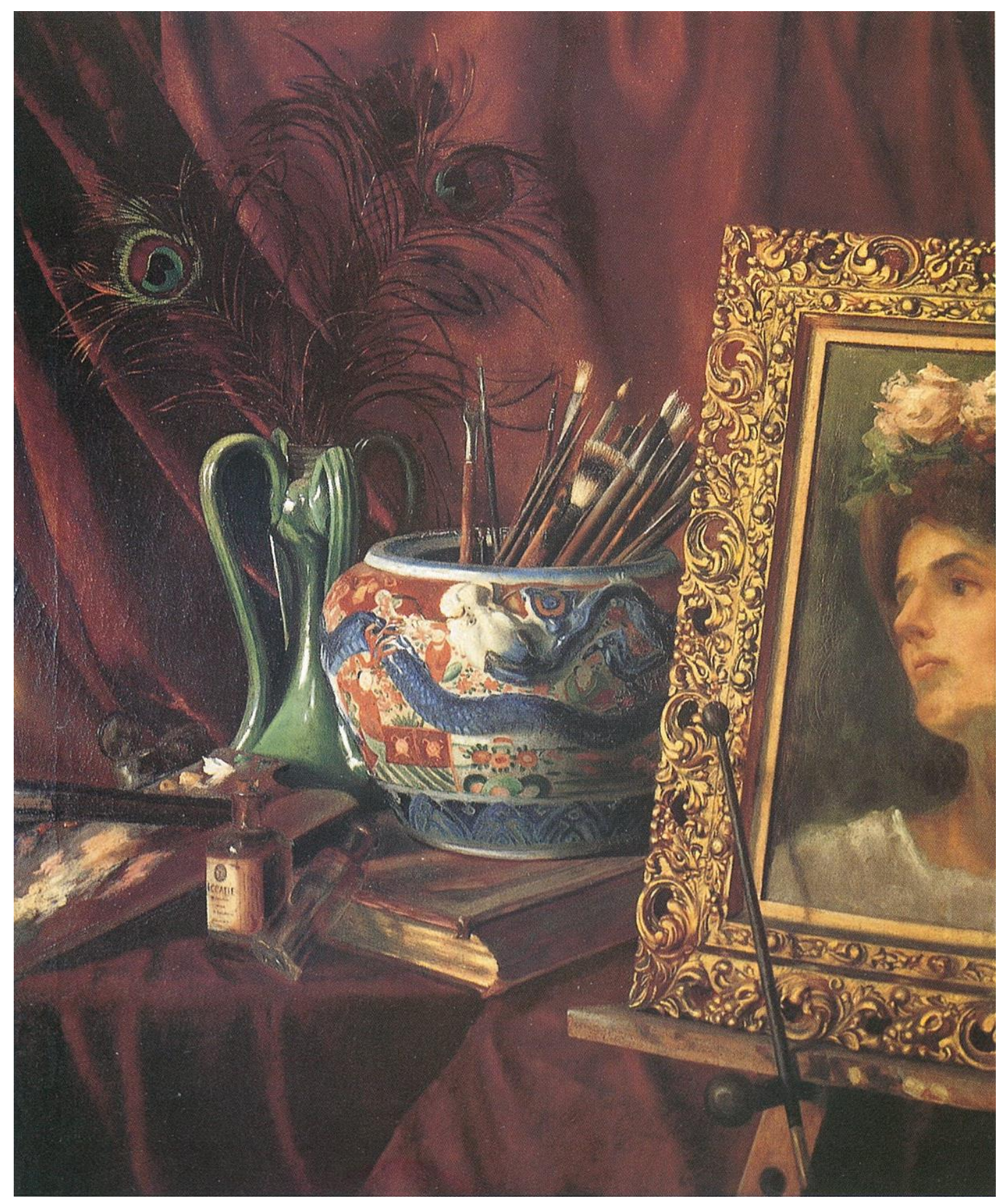

Plate 33: Charles F. Goldie, Study of a Still Life, c. 1890 (private collection). 


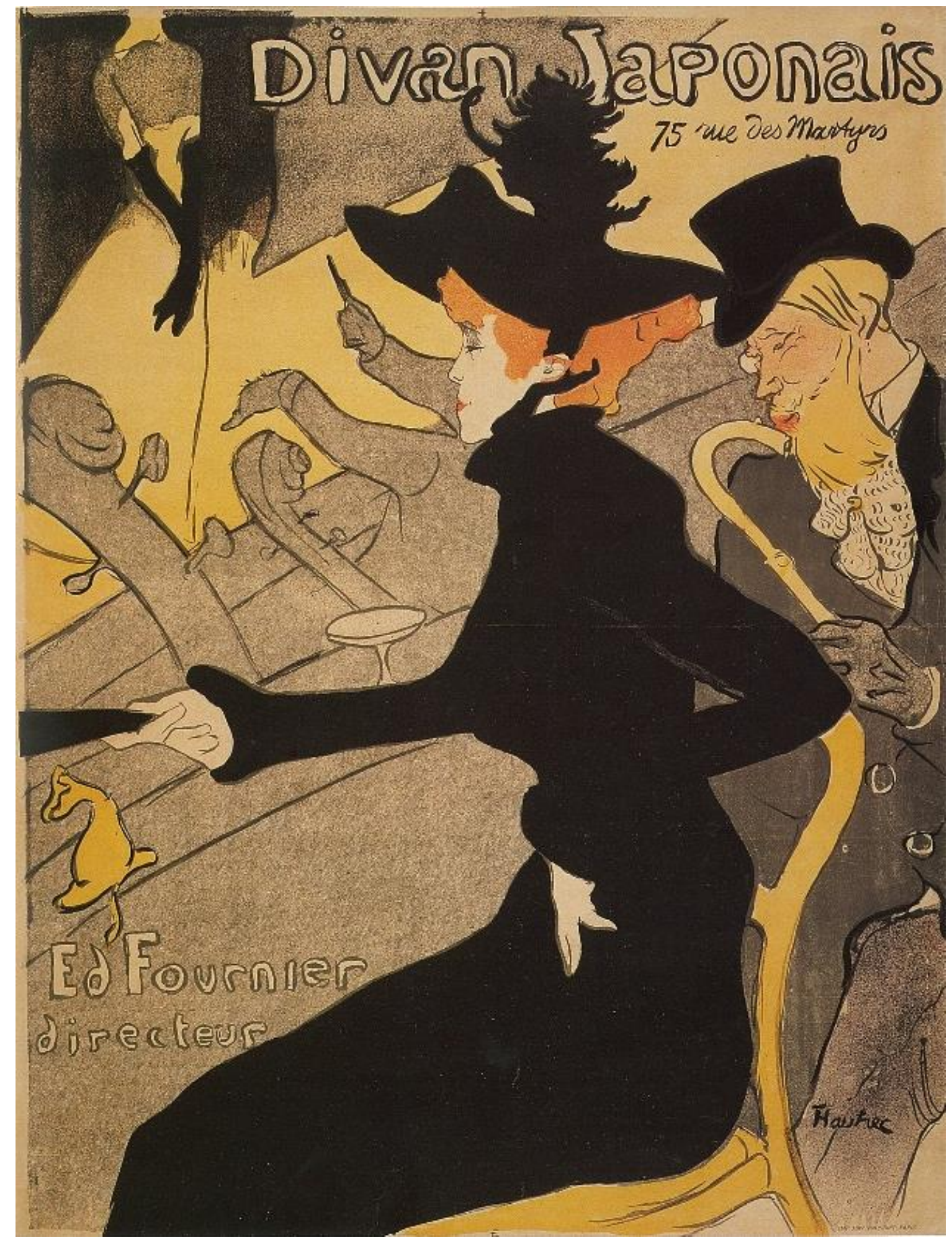

Plate 34: Henri Toulouse-Lautrec, Divan Japonais, 1892-93 (Brisbane: Queensland Art Gallery). 


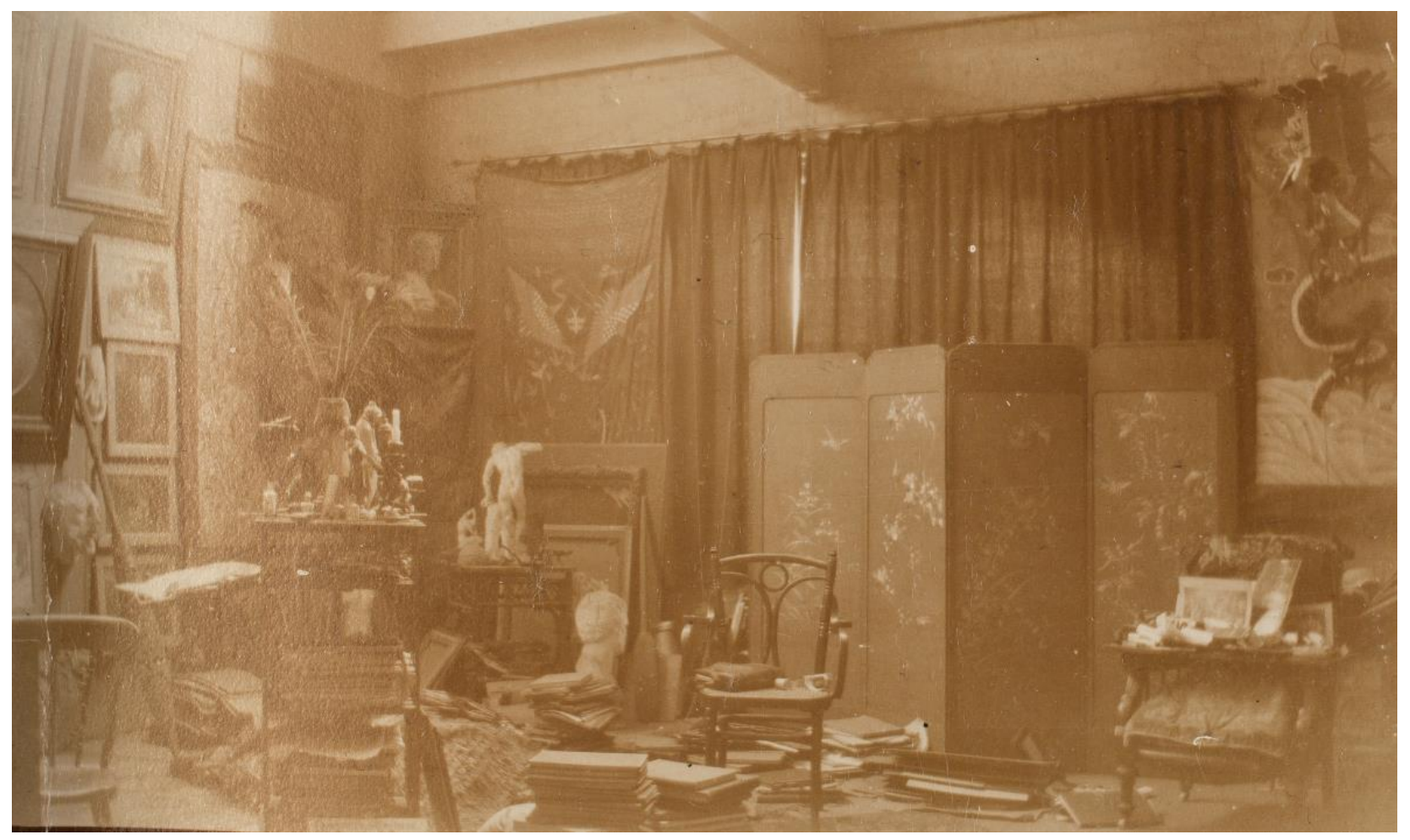

Plate 35: An intimate view of Goldie's studio behind the camera, c. 1900. Goldie Scrapbook, 11, (Auckland War Memorial Museum Library: Box 6, MS-438). 


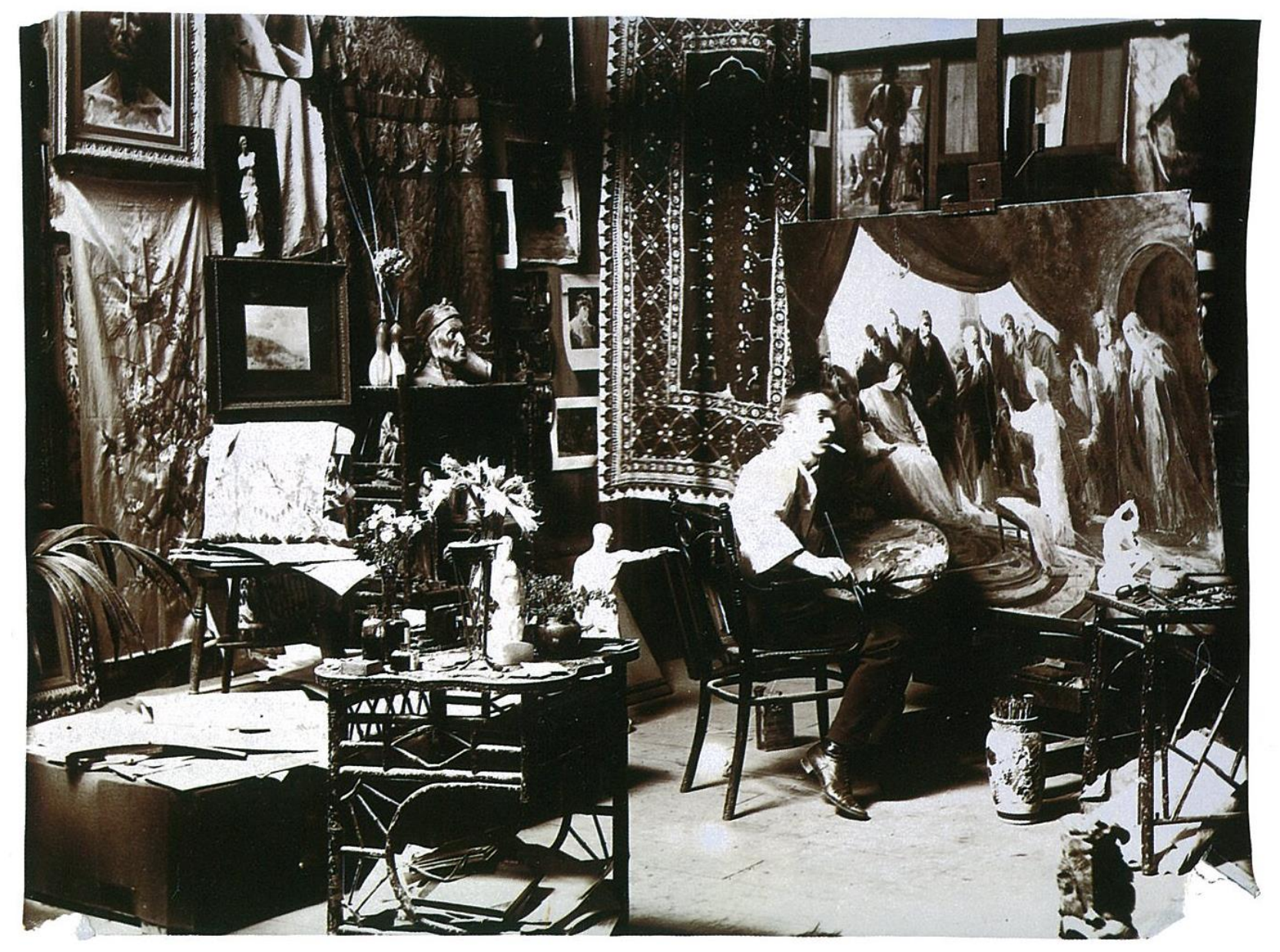

Plate 36: Unidentified Photographer, Goldie in his Studio, Hobson's Buildings, c. 1900. (Auckland Art Gallery Toi o Tāmaki, gift of the Goldie Family, 1995). 


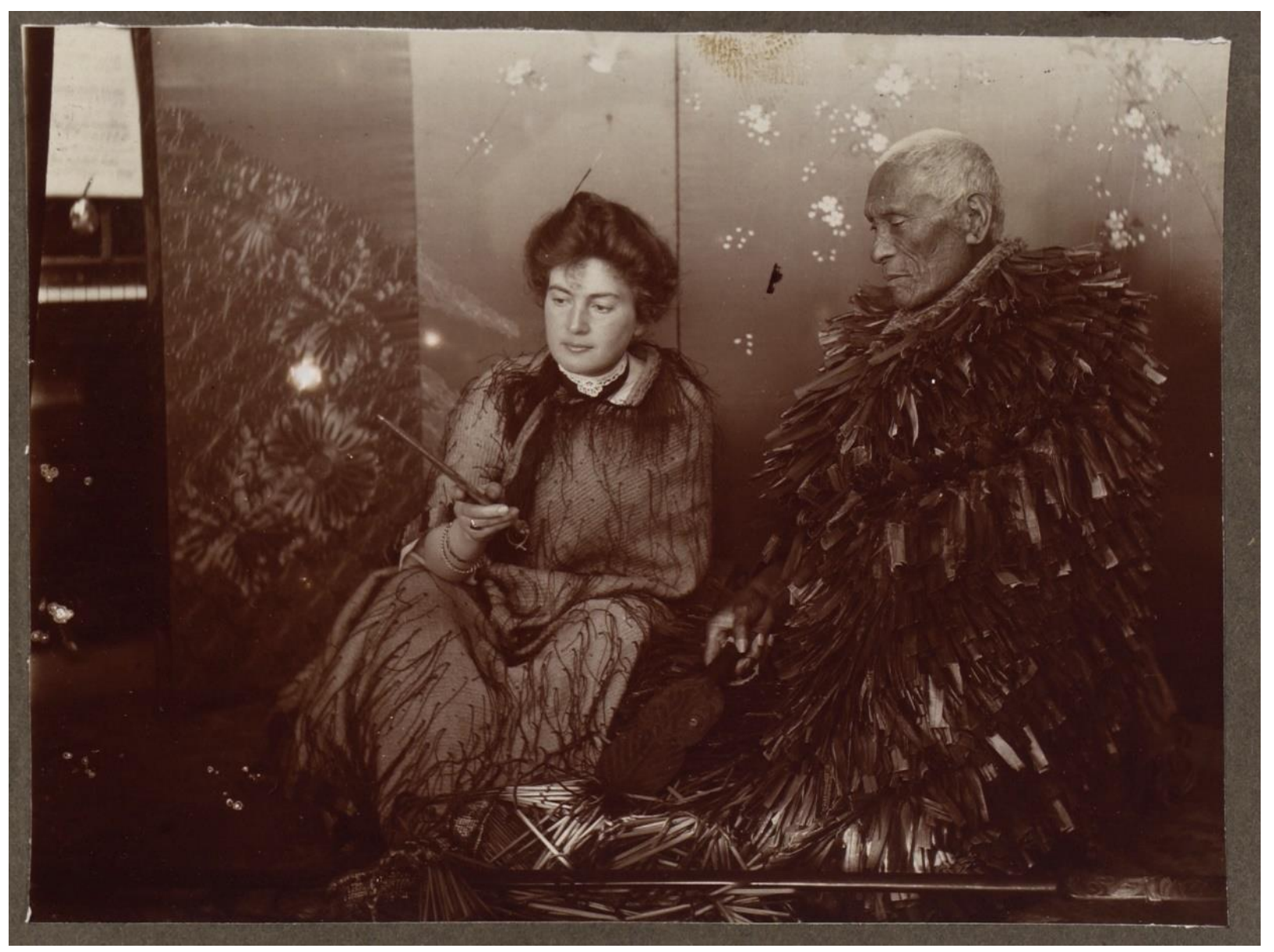

Plate 37: Kamariera Te Wharepapa with a visitor to Goldie's studio, undated, (Auckland Art Gallery Toi o Tāmaki, gift of the Goldie Family, 1995). 


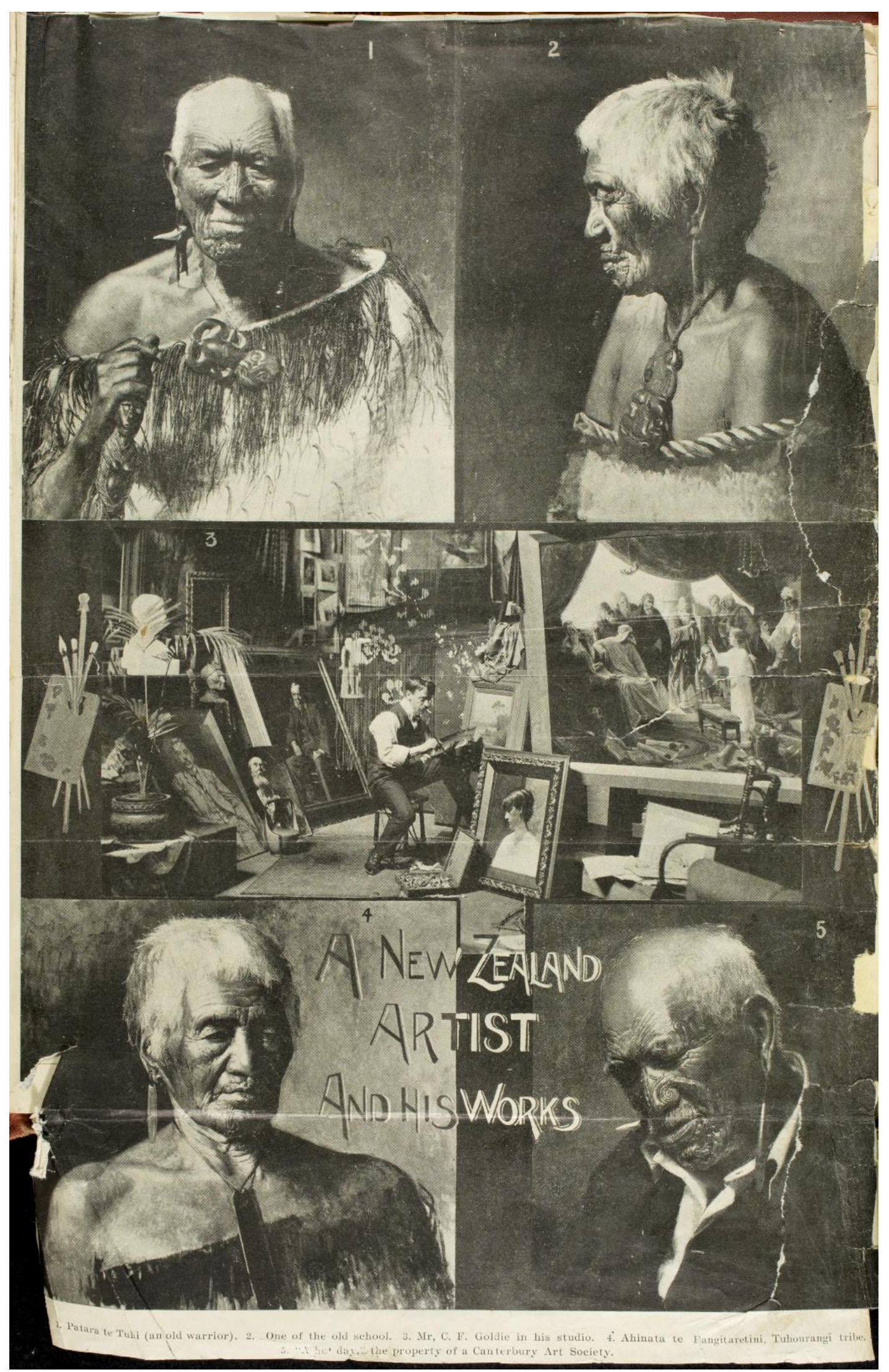

Plate 38: Newspaper clipping of Goldie posing in his studio with Sorrowful Moments resting near the artist's feet in the New Zealand Graphic, 24 May 1902, 1018. Cited: Goldie Scrapbook, 11, 95 (Auckland War Memorial Museum Library: MS-438). 


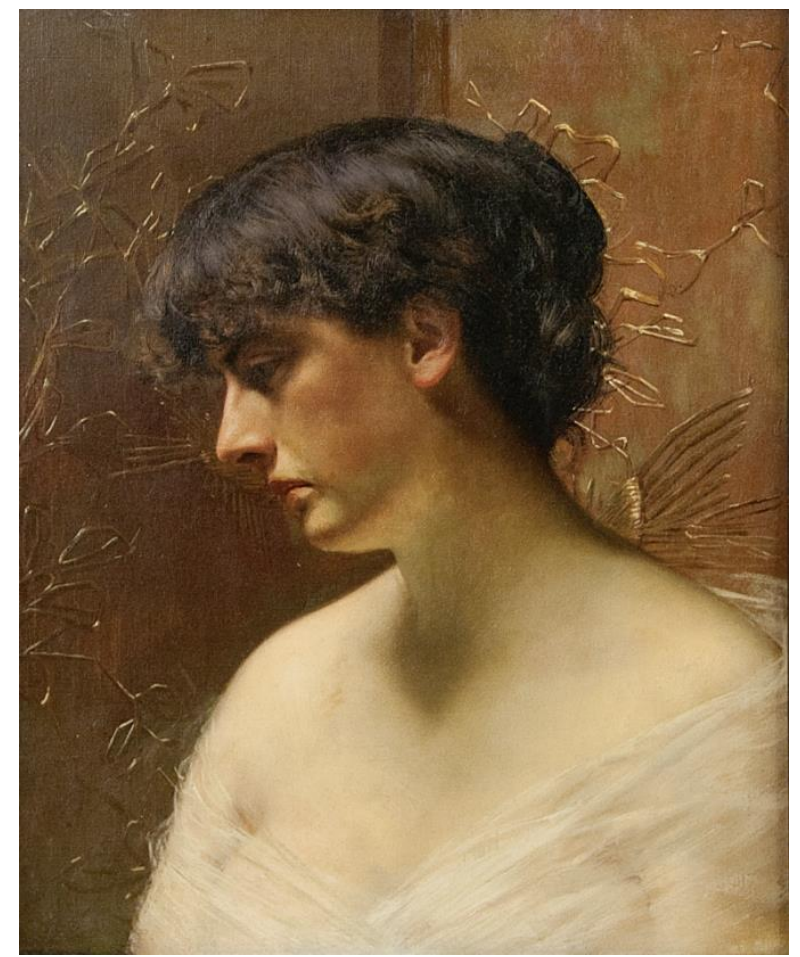

Plate 39: Charles F. Goldie, Sorrowful Moments, c. 1900 , oil on canvas, (Image courtesy of MossgreenWebb's, Auckland, now housed in a private collection).

Plate 40: William-Adolphe Bouguereau, Irène, 1897 (private collection).

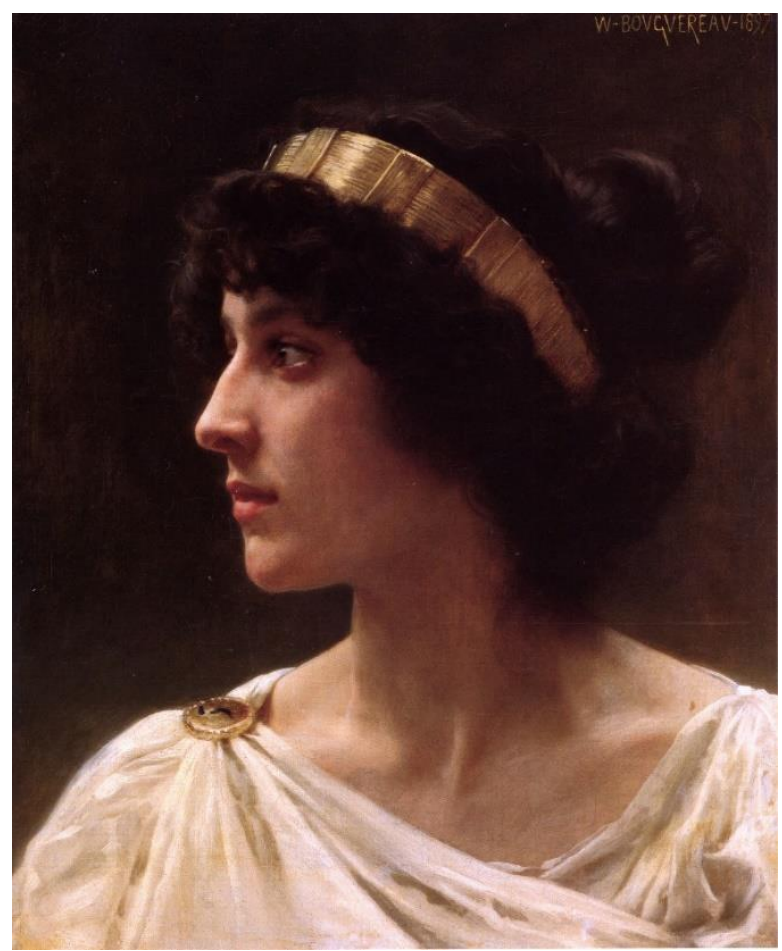




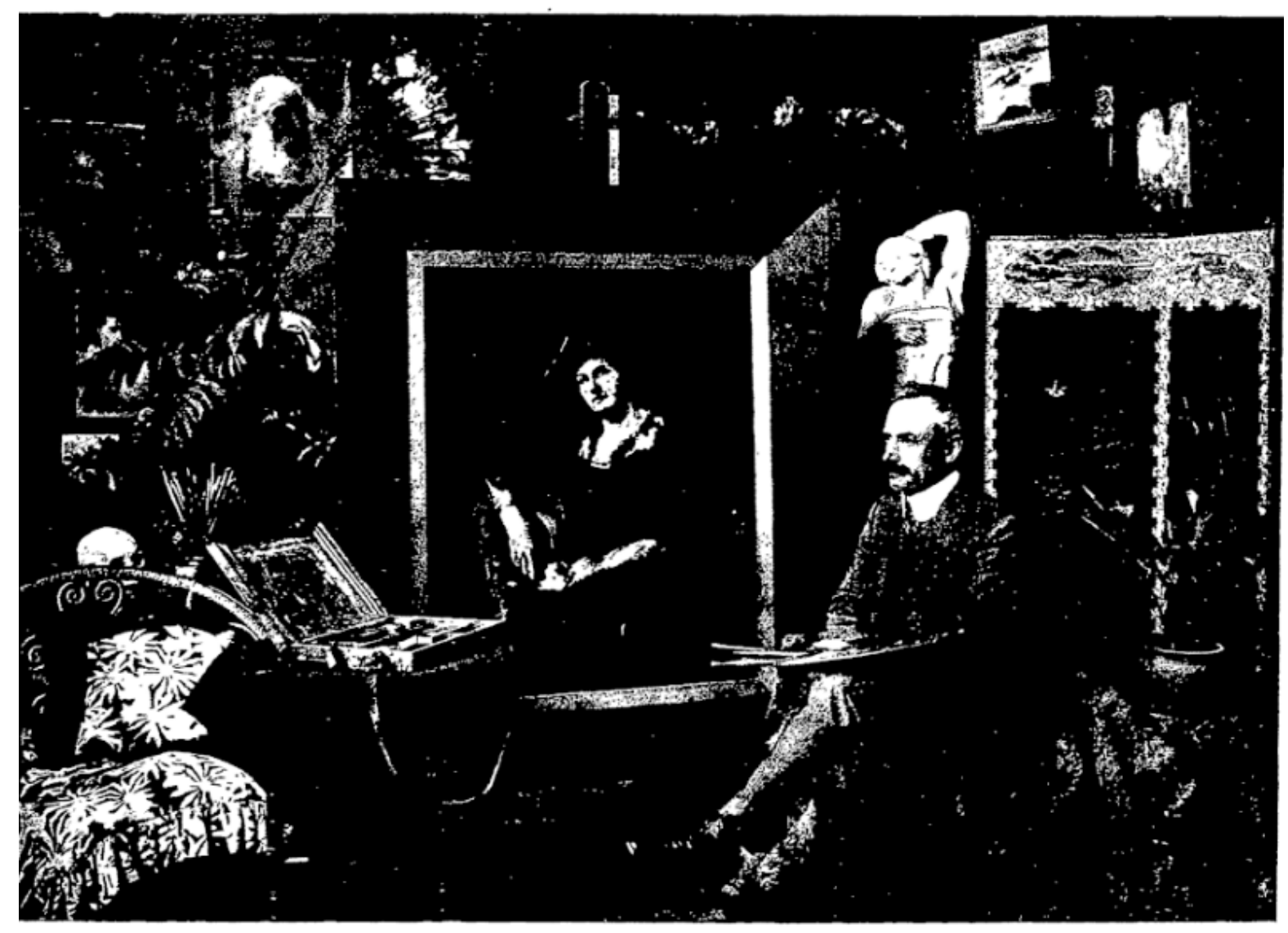

DUNE JIN ARTISTS $1 X$ THEIS STUDIOS: NO. 10-MR A. H. O'KEEFE.

Plate 41: Mr A. H. O'Keeffe in his oriental studio in Princes Street, Dunedin. Published in Otago Witness, 10 March 1909, 50. 


\section{BIBLIOGRAPHY}

\section{Unpublished: Correspondence, Files and other Archival Material}

\section{Alexander Turnbull Library, Wellington:}

Alcorn Family Album and Papers: Wellington Technical School (PAColl-3016).

Clere, Frederick de Jersey, Letter to Stanley Edwards, 9 July 1939 (MS-Papers-1438).

Cowan, James, Letters from C. F. Goldie (MS-Papers-5438).

Crompton-Smith, M., Letter to Stanley Edwards, 10 July 1939 (MS-Papers-1438).

Field and Hodgkins Family Papers (MS-Papers-0113-06/1).

Field, William Hughes, Scrapbook (E-313-q).

Goldie, C. F., Letters to Grace Hesketh (A-252-010/013).

Hill, Mabel, 'James McLachlan [sic] Nairn', 1 September 1939 (MS-Papers- 5581). letter to S. Edwards, 17 September 1939 (MS-Papers-1438).

_. Sketchbook. 1890-1898 (E-514).

Hodgkins, Frances, Correspondence 1875-1946, (MS-85).

Nairn, James M. to Mabel MacIndoe (née. Hill), 2 February 1896 (MS-Papers-5581).

Nairn, James M. to Mabel MacIndoe (née. Hill), 19 August 1898, (MS-Papers-5581).

McGregor-Wright, J. P., letter to S. Edwards, 22 June 1939 (MS-Papers-1438).

McGregor-Wright, J. P., letter to S. Edwards, 13 July 1939 (MS-Papers-1438).

Mills, Tom L., replying to S. Edwards, July 1939. (MS-Papers-1438).

Murray-Oliver, Anthony Audrey St Clair, 'Brief Notes on James McLauchlan Nairn, Artist', 24 July 1939 (qMS-1402).

Ramsden, Eric papers (MS-Papers-0196-266).

Tustin, Mabel, reply letter to S. Edwards, 20 September 1939 (MS-Papers-1438).

Unknown author, 'James Nairn, Appreciation', date unknown (MS-Papers-1438). 
'Wise's Post Office Directory 1896-97', Dunedin: Wise's Directories, 1896. (FHCNZ/LIST (FICHE)).

\section{Auckland War Memorial Museum Library:}

Goldie's Scrapbooks (MS-438).

\section{Dunedin City Council Archives:}

Otago Art Society Exhibition Catalogues, 1876-1924 (Box 1).

Otago Art Society Minutes 1875-1922 (Box 1).

Valuation Department Series I, Valuation Rolls, 1890-91.

\section{Hocken Library, Dunedin:}

Catalogues of Otago Art Society Exhibitions 1890-1904 (MS-2114/028).

Esplin, Tom, Papers relating to New Zealand artists (MS-1242).

Haddon, A. C., letter to Balfour entitled, 'Evolution of Decorative Art', 1893, 1895 (MS 1219/119).

Hutton, K. S., 'Revised biography of D. E. Hutton', 1969 (Misc-MS-34, 1970).

'Revision of the manuscript biography of D. E. Hutton', 1969 (Misc-MS-17, 1969).

Hocken, Dr. Thomas Morland, 'Scrapbook of New Zealand and South Seas Exhibition' (MS-0451/038).

'Correspondence' (MS-0451-020).

Joel, Maurice, Letters and article about Grace Joel (MS-0996-003/087).

King, Bella, Diary 1903-1904 (AG-75-35).

Notebook, (AG-007-005/033).

Letter Book, Correspondence for New Zealand and South Seas Exhibition, November 1889-December 1891 (MS-0340).

'Otago Art Society Exhibition Manuscript relating to 1894 exhibition' (Misc-MS0341).

\section{Museum of New Zealand Te Papa Tongarewa Library, Wellington:}

Goldie, C. F. to Augustus Hamilton, 29 September 1910.

Goldie, Elsie: Writing Album; 1898-1922 (Ref. CA000253/001/0001). 
Goldie, Charles F., Scrapbook 1909-1937. (Ref. CA000252/001/0001).

Nairn, James McLauchlan, Scrapbook of newspaper clippings (compiled by Tony Mackle).

\section{$\underline{\text { Artist Files: }}$}

Alfred Henry O’Keeffe

Charles F. Goldie.

Girolamo P. Nerli

Frances Hodgkins

James M. Nairn

Mary Tripe (née. Richardson)

Raymond F. McIntyre

Thomas Ryan

\section{National Archives}

Bell, Francis Dillon, Agent General, London, 'Correspondence and consent to display Sir Frederic Leighton's Phryne', 1889-90 (Ref no. IA1 578).

Archives New Zealand, Passenger Lists, 1839-1973, FHL microfilm.

\section{Unpublished Theses:}

Campbell, Laura, 'James McLauchlan Nairn: Through an Aesthetic Lens', B. A. (Hons.) Research Essay, Art History, Wellington: Victoria University of Wellington, 2014.

Campbell, Penelope, 'Collecting the Pacific 1768-1977: Joseph Banks, Alexander Turnbull, Rex Nan Kivell', M. A., Art History, Wellington: Victoria University of Wellington, 2002.

Currie, Betty, 'Girolamo Pieri Nerli', B. A. (Hons) Art History, Fine Arts Department, University of Melbourne, 1976.

Harris, J., 'The Artist's Mission to the Philistines: James M. Nairn and Art in Wellington in the 1890s', Wellington: Victoria University of Wellington, 1983.

Hearnshaw, Victoria 'James McLauchlan Nairn: The Glasgow Years', B. A. (Hons.) Research Essay, Art History, Christchurch: University of Canterbury, 1990. 
'James McLauchlan Nairn: The New Zealand Years', M. A., Art History, Christchurch: University of Canterbury, 1992.

Morgan, Benjamin Joseph, 'The Matter of Beauty: Materialism and the Self in Victorian Aesthetic Theory', PhD Thesis, Berkeley: University of California, 2010.

Norman, Mathew, 'Print Collection of Bishop Monrad (1811-1887)', M. A., Art History, Wellington: Victoria University of Wellington, 2006.

Petersen, Anna K. C., 'Signs of Higher Life: A Cultural History of Domestic Interiors in New Zealand 1814-1914', PhD Thesis, Dunedin: University of Otago, 1998.

Rice, Rebecca, 'Picturing Progress in Paradise: New Zealand on Display at International Exhibitions 1873-1886', M. A., Art History, Wellington: Victoria University of Wellington, 2003.

'The State Collections of Colonial New Zealand Art: Intertwined Histories of Collecting and Display', PhD Thesis, Art History, Wellington: Victoria University of Wellington, 2010.

Vaughan, Gerard, 'Maurice Denis: His Place in the Parisian Milieu and Some Sources for his Imagery, 1890-1910', B. A. (Hons.), Art History, Melbourne: University of Melbourne, 1976.

Vial, Jane, 'How Amateurish was Wellington Art Prior to James Nairn's Arrival in 1890 ?', B. A. (Hons.) Research Essay, Art History, Wellington: Victoria University of Wellington, 1991.

, 'Painting in New Zealand and Australia 1884-1904', M. A., Art History, Wellington: Victoria University of Wellington, 1993.

\section{Published Books and Articles:}

Adams, Elsie B., Bernard Shaw and the Aesthetes, Columbus: Ohio State University Press, 1971.

Adburgham, Alison, Liberty's: A Biography of a Shop, London: Allen \& Unwin, 1975. Aldington, Richard, The Religion of Beauty: Selections from the Aesthetes, London: William Heinemann, 1950.

Aslin, Elizabeth, The Aesthetic Movement: Prelude to Art Nouveau, London: Elek Publishing, 1969.

E. W. Godwin: Furniture and Interior Decoration, London: John Murray Publishers, 1986. 
Astbury, Leigh, 'Around the Studios: Girolamo Nerli, The Sitting', in Lynne Sear and Julie Ewington (eds.), Brought to Light: Australian Art 1850-1965, Brisbane: Queensland Art Gallery, 1998.

Auckland Art Gallery Toi o Tāmaki, Auckland, Art Toi, New Zealand Art at Auckland Art Gallery Toi o Tãmaki, edited by Ron Brownson, 2011.

Raymond McIntyre: A New Zealand Painter, Auckland: Heinemann Publishers Ltd, 1984.

Barringer, Tim and Elizabeth Prettejohn (eds.), Frederic Leighton: Antiquity, Renaissance, Modernity, New Haven and London: Yale University Press, 1999.

Bayly, Janet, Frances Hodgkins in Kapiti: The Field Collection (exhibition catalogue), Wellington: Mahara Gallery, 2014.

Bell, David, 'Bella King in Japan and China: Travelling and Collecting in the Early Twentieth Century', New Zealand Journal of Asian Studies, 14, December 2012, 67-85.

Bell, Leonard, Colonial Constructs: European Images of the Māori, 1840-1914, Auckland: Auckland University Press, 2013.

'Is Art Global? Reflections from Another Place', Is Art History Global?, James Elkins (ed.) New York \& London: Routledge, 2007, 376-77.

,'The Representation of the Maori by European Artists in New Zealand, c. 1890 1914', Art Journal, 49, 2, 1990, 142-149.

Billcliffe, Roger, Pioneering Painters: The Glasgow Boys, Glasgow: Kelvingrove Art Gallery and Museum, 2010.

Bills, Mark and Barbara Bryant, G. F. Watts, Victorian Visionary, New Haven and London: Yale University Press, 2008.

Bills, Mark and David Webb, Victorian Artists in Photographs: The World of G.F. Watts, Selections from The Rob Dickens Collection, Surrey, U. K.: Watts Gallery, 2007.

Blackley, Roger, 'As Rembrandt would have painted the Māori', Auckland: Gow Langsford Gallery, 2013, 2-3.

, 'First Impressionists', Listener, 17 July 2010, 44.

Goldie, Auckland: Auckland Art Gallery Toi o Tāmaki, David Bateman, 1997.

, 'Goldie: New Zealand's Old Master', Australian Antique Collector, July-December 1998, 94-98.

, The Art of Alfred Sharpe, Auckland: Auckland Art Gallery Toi o Tāmaki, David Bateman, 1992. 
,'The Exhibitions of Māori Art in Auckland 1884-1885: Documents of the New Zealand Art Students Association', Antic 3, 1984, 116-122.

, The Māori in European Art, Wellington: A. H. \& A. W. Reed, 1980.

,Two Centuries of New Zealand Landscape Art, Auckland: Auckland City Art Gallery, 1992.

,'Working with Goldie', Off the Wall, 1, March 2013. http://arts.tepapa.govt.nz/ off-the-wall/4166/working-with-goldie. Accessed: 6 January 2016.

Blackman, Margery, Dorothy Theomin of Olveston, Dunedin: Friends of Olveston, 2007.

Blunt, Wilfrid, A Biography of George Frederic Watts: England's Michelangelo, London, Hamish Hamilton, 1975.

Body, Ralph, 'The Doyen of Dunedin Art: Alfred Henry O'Keeffe's Late Works', The Journal of New Zealand Art History, 30, 2009, 17-36.

Brown, Gordon H., New Zealand Painting 1900-1920: Traditions and Departures (New Zealand Painting Series I), Wellington: Queen Elizabeth II Arts Council of New Zealand, 1972.

,'Signor Nerli: The Painter', Auckland City Art Gallery Quarterly, 45, 1969, 3-15. and Hamish Keith, An Introduction to New Zealand 1839-1980, Auckland: David Bateman and William Collins, $2^{\text {nd }}$ ed., 1982.

Brown, Warwick, 100 New Zealand Paintings, Auckland: Godwit Publishing, 1995.

Brown-Price, Aimée, Pierre Puvis de Chavannes, 2 vols., New Haven and London: Yale University Press, 2010.

Brown-Price, Aimée, Jon Whiteley and Geneviève Lacambre, Pierre Puvis de Chavannes, Amsterdam and New York: Van Gogh Museum and Rizzoli International, 1994.

Buchanan, William, Mr Henry and Mr Hornel visit Japan, Edinburgh: Scottish Arts Council, 1978.

Burn, Ian, National Life \& Landscapes: Australian Painting 1900-1940, Sydney, Australia and London U. K.: Bay Books, 1990.

Calhoun, Ann, The Arts \& Crafts Movement in New Zealand 1870-1940, Auckland: Auckland University Press, 2000.

, Arts and Crafts Design: Like Yet Not Like Nature, Sources for a New Zealand Story, ebook, 2015. http://www.artsandcraftsnz.co.nz/uploads/9/8/3/5/9835758/ artsandcraftsnz_ann_calhoun_2015_v108.pdf. Accessed: 22 January 2016. 
Calloway, Stephen and Lynn Federle Orr (eds.), The Cult of Beauty: The Aesthetic Movement 1860-1900, V\&A Publishing, 2011.

Casteras, Susan P., and Colleen Denney, The Grosvenor Gallery: A Palace of Art in Victorian England, New Haven \& London: Yale University Press, 1996.

Chapman, Barbara, 'Nerli, Girolamo Pieri Ballati (1860-1926)', Australian Dictionary of Biography, 10, 1986. http://adb.anu.edu.au/biography/nerli-girolamo-pieriballati-7740. Accessed: 23 November 2015.

Checkland, Olive, Japan and Britain after 1859: Creating Cultural Bridges, New York and London: Routledge, 2003.

Chesterman, Sandra, Figure Work: The Nude and Life Modelling in New Zealand Art, Dunedin: University of Otago Press, 2002.

Christchurch Art Gallery Te Puna o Waiwhetu, Christchurch, Owen Merton, Expatriate Painter, curated by R. D. J. Collins (exhibition catalogue), Christchurch, 2004.

'Christie's Auction House, Sale of George Frederick Watts Alfred, Lord Tennyson, c. 1863-64', sold at auction on 25 March 1994, lot 73. http://www.christies.com/ lotfinder/LotDetailsPrintable.aspx?intObjectID=245817. Accessed: 21 July 2015.

Clark, Jane and Bridget Whitelaw (eds.), Golden Summers: Heidelberg and Beyond, Sydney: International Cultural Corporation of Australia, 1985.

Clifford, James, The Predicament of Culture: Twentieth-Century Ethnography, Literature and Art, Cambridge, Harvard University Press, 1988.

Cohen, Deborah, Household Gods: The British and their Possessions, New Haven and London, 2006.

Collins, Roger, 'A Note on Two Paintings by G. P. Nerli', The Journal of New Zealand Art History, 27, 2006, 89-91.

Colvin, Sidney, 'English Painters and Painting in 1867', Fortnightly Review, 1 October 1867.

Crane, Walter, 'The Prospects of Art under Socialism', The Scottish Art Review, 1, 4, September 1888, 81-83. https://archive.org/stream/scottishartrevie01unse\#page/ n5/mode/2up. Accessed: 16 May 2015.

,An Artist's Reminiscences, New York: Macmillan, 1907.

Currie, Betty, 'Signor Nerli' , Art and Australia, 16, 1, September 1978, 55-60.

Day, M. N., 'Raymond Francis McIntyre 1879-1933', Art New Zealand, Winter 1978, 11, 32-39. 
Denvir, Bernard, The Late Victorians: Art, Design and Society 1852-1910, London and New York: Longman, 1986.

Dickinson, Frank, Grace Joel, Paintings and Drawings, Dunedin: Dunedin Public Art Gallery, 1980.

Docking, Gil, Two Hundred Years of New Zealand Painting With Additions by Michael Dunn Covering 1970-90, Auckland: David Bateman, $3^{\text {rd }}$ ed., 1990.

Dunn, Michael, New Zealand Painting: A Concise History, Auckland: Auckland University Press, 2003.

$\ldots$ Nerli: An Italian Painter in the South Pacific, Auckland: Auckland University Press, 2005.

_. 'Notes on Nairn in Glasgow,' Bulletin of New Zealand Art History, 5, 1977, 11-14.

__., 'The Other Expatriate', Art New Zealand, 33, 1984, 43-45.

Frances Hodgkins: A Private Viewing, Auckland: Random House, 2005.

Eastmond, Elizabeth, Michael Dunn and Iain Buchanan, Frances Hodgkins: Paintings and Drawings, Auckland: Auckland University Press, 1994.

Eccles, Alfred, The First New Zealand Exhibition and Dunedin in 1865, Dunedin: Crown Print, 1925.

Edgar, Charlton and Oliver G. Cox (eds.), 'Otago School of Art Centennial Exhibition 1870-1970', Dunedin: Dunedin School of Art, 1970.

Edwards, Deborah, Margaret Preston, Sydney: Art Gallery of New South Wales, 2005.

Edwards, Stanley H. and John Magurk, 'James Nairn: Artist', Art in New Zealand, 12, June 1940, 220-225.

Eggleton, David, Towards Aotearoa: A Short History of Twentieth-Century New Zealand Art, Auckland: Reed Publishing Ltd, 2007.

Entwisle, Peter, William Mathew Hodgkins \& His Circle, Dunedin: Dunedin Public Art Gallery, 1984.

Entwisle, Peter, Michael Dunn, and Roger Collins, Nerli: An Exhibition of Paintings \& Drawings (exhibition catalogue), Dunedin: Dunedin Public Art Gallery, 1988.

Ensing, Riemke, 'Frances Hodgkins in Kapiti: The Field Collection at Mahara Gallery', Art New Zealand, 150, Winter 2014, 92-94.

Fairburn, A. R. D., 'Some Aspects of New Zealand Art and Letters', Art in New Zealand, 24, June 1934, 213-18. 
Field, Jemma, 'Charles Frederick Goldie, Sorrowful Moments', Auckland: Webb's Auction House, August 2011. www.webbs.co.nz/auction-item/sorrowful-moments. Accessed: 14 July 2015.

Fletcher, Pamela and Anne Helmreich, The Rise of the Modern Art Market in London, 1850-1939, Manchester: Manchester University Press, 2011.

Fowle, Frances, and National Galleries of Scotland, Van Gogh's Twin: The Scottish Art Dealer Alexander Reid, Edinburgh: National Galleries of Scotland, 2010.

Franklin-Gould, Veronica, G. F. Watts, The Last Great Victorian, New Haven and London: Yale University Press, 2004.

Galbally, Ann, 'Aestheticism in Australia', in Anthony Bradley and Terry Smith (eds.), Australian Art and Architecture: Essays Presented to Bernard Smith, Melbourne: Oxford University Press, 1980, 124-33.

Gere, Charlotte, Artistic Circles: Design \& Decoration in the Aesthetic Movement, London: V\&A Publishing, 2010.

Gere, Charlotte and Lesley Hoskins, The House Beautiful: Oscar Wilde and the Aesthetic Interior, London: Lund Humphries, 2000.

Gibbons, P. J., 'The Climate of Opinion', The Oxford History of New Zealand, Geoffrey Rice (ed.), 2 ed., Auckland: Oxford University Press, 1992.

Gill, Linda (ed.), Letters of Frances Hodgkins, Auckland: Auckland University Press, 1993.

Glasgow Art Club Book, Glasgow: National Library of Scotland, 1885.

Glazer, Lee and Linda Merrill (ed.), Palaces of Art: Whistler and the Art Worlds of Aestheticism, Washington D.C.: Smithsonian Institution Scholarly Press, 2013.

Goldie, C. F., 'Art Crisis, Auckland Art Gallery' , Battle of the Schools: Modernism Condemned', New Zealand Herald, 28 September, 1934, 15.

Hallum, Kirby-Jane, Aestheticism and the Marriage Market in Victorian Popular Fiction: The Art of Female Beauty, London: Routledge, 2015.

Hamilton, Augustus, Maori Art, Wellington: New Zealand Institute, 1901.

Hamilton, Walter, The Aesthetic Movement in England, New York and London: Garland Publishing, 1986.

Hammerschlag, Keren Rosa, Frederic Leighton: Death, Mortality, Resurrection. British Art: Histories and Interpretations since 1700, Surrey, U. K.: Ashgate, 2015. 
Harrison, Noel, The School that Riley Built: The Story of the Wellington Technical College from 1886 to the Present Day, Wellington: Wellington Technical College, 1961.

Haskell, Francis and Nicholas Penny, Taste and the Antique: The Lure of Classical Sculpture, 1500-1900, New Haven and London: Yale University Press, 1981.

Haweis, M., The Art of Beauty, New York: Harper, 1878.

Hearnshaw, Vicky, 'James McLauchlan Nairn: A Catalogue of Work', Bulletin of New Zealand Art History, 3, Dunedin: Hocken Library, 1997.

Hocken Library, 'One Before Breakfast: J. M. Nairn, G. P. Nerli, P. Van der Velden', Dunedin: University of Otago, 1988.

Hodgkins, W. M., 'A History of Landscape Art and its Study in New Zealand', ODT, 20 November 1880, Supplement, 5.

,The Exhibition', ODT, 2 December 1889, 2.

Hoff, Ursula, Charles Conder, Melbourne: Lansdowne Press, 1972.

Holland, Clive, 'Student Life in the Quartier Latin, Paris', The Studio, 27, 1902, 33-40.

Houghton, Walter E., The Victorian Frame of Mind 1830-1870, New Haven: Yale University Press, 1957.

Hunterian Art Gallery Whistler Collections, 'Whistler, James McNeill'. http://www. huntsearch.gla.ac.uk/cgi-bin/foxweb/huntsearch/ DetailedResults.fwx? collection=whistler \&SearchTerm=46379\&reqMethod=Link. Accessed: 19 November 2015.

Inglis, Alison, 'Aestheticism and Empire: The Grosvenor Gallery Inter -Colonial Exhibition in Melbourne, 1887', Seize the Day: Exhibitions, Australia and the World, Kate Darian-Smith, Richard Gillespie, Caroline Jordan, and Elizabeth Willis (eds.), Melbourne: Monash University, ePress, 2008. http://books.publishing.monash.edu/ apps/bookworm/view/SEIZE+THE+DAY/123/xhtml/chapter1.html. Accessed: 28 September 2015.

Jackson, Penelope, Neil Roberts, Lara Strongman, Images of Home and Garden, Christchurch: Robert McDougall Art Gallery, and Trust Bank Canterbury, 1991.

Kanopy Film Production, Whistler: For Art's Sake, 2014. https://vuw-

kanopystreaming-com.helicon.vuw.ac.nz/video/whistler-arts-sake. Accessed: 3 January 2016.

Kay, Robin and Tony Eden, Portrait of a Century: the History of the NZ Academy of Fine Arts, Wellington: Millwood Press, 1983. 
Keith, Hamish, New Zealand Art: Painting 1827-1890, A. H. \& A. W. Reed, 1968. Images of Early New Zealand Painting, Auckland: David Bateman, 1983. 'James McLauchlan Nairn 1859-1904', Auckland City Art Gallery Quarterly, 25, 1963, 4-7.

Kirker, Anne, New Zealand Women Artists, Auckland: Reed Methuen, 1986. ,'Special Feature, The Nairn Screen: A New Acquisition', National Art Gallery Newsletter, April-June 1988, 6-7.

Kōdera, Tsukasa, 'Japan as Primitivistic Utopia: Van Gogh's Japonisme Portraits', Simiolus: Netherlands Quarterly for the History of Art, 14, 3, 1984, 189-208.

Lambourne, Lionel, Japonisme: Cultural Crossings between Japan and the West, London: Phaidon Press Limited, 2005.

The Aesthetic Movement, Oxford: Phaidon, 2011.

Lane, Terence, Australians at Home: Documentary History of Australian Domestic Interiors from 1788 to 1914, Oxford: Oxford University Press, 1990.

, Australian Impressionism, Melbourne: National Gallery of Victoria, 2007.

Le Gallienne, Richard, The Romantic '90s, London: Putnam, 1926.

Leighton House Museum, 'Phryne at Eleusis'. https://www.rbkc.gov.uk/lordleightons drawings/ldcollection/paintingrecord.asp?workid=803. Accessed: 3 November 2015.

MacCarthy, Fiona, 'The Aesthetic Movement', Guardian, 26 March 2011.

http://www.theguardian.com/artanddesign/2011/mar/26/aestheticism-exhibitionvictoria-albert-museum. Accessed: 7 August 2015.

Macleod, Dianne Sachko, Art and the Victorian Middle Class: Money and the Making of Cultural Identity, Cambridge: Cambridge University Press, 1996.

McAloon, William, (ed.), Art at Te Papa, Wellington: Te Papa Press, 2009.

McCahon, Colin, James Nairn and Edward Fristrom, (exh. catalogue), Auckland: Auckland City Art Gallery, 1964.

Six New Zealand Expatriates: Grace Joel, Rhona Haszard, Frances Hodgkins, Francis McCracken, Raymond McIntyre, Owen Merton, (exh. catalogue), Auckland: Pelorus Press, 1962.

McLaren-Young, Andrew, Margaret MacDonald, Hamish Miles and Robin Spencer, The Paintings of James McNeill Whistler, New Haven and London: Yale University Press, 1980, 85. 
McCormick, E. H., Alexander Turnbull: His Life, His Circle, His Collections, Wellington: Alexander Turnbull Library, 1974.

, Letters and Art in New Zealand, Wellington: Department of Internal Affairs New Zealand, 1940.

,The Expatriate: A Study of Frances Hodgkins in New Zealand, Wellington: New Zealand University Press, 1954.

Works of Frances Hodgkins in New Zealand, Auckland: Auckland City Art

Gallery, 1954.

Maas, Jeremy, Victorian Painters, London: Barrie \& Jenkins, 1969.

Main, William, New Zealand Photography from the 1840s to the Present, Auckland: Photoforum, 1993.

Mackle, Anthony, Grace Joel 1865-1924, Paintings and Drawings, Dunedin: Dunedin Public Art Gallery, 1980.

Mackle, Anthony and Ann Calhoun, Aspects of New Zealand Art 1890-1940, Wellington: National Art Gallery, 1984.

Mason, Elizabeth and Jane Vial, 'Mabel Hill 1872-1956: A Memoir', Bulletin of New Zealand Art History, 2, 1990, 19-27.

Metzger, Rainer and Ingo F. Walther, Vincent van Gogh 1853-1890, Köln: Taschen, 2008.

Montana, Andrew, The Art Movement in Australia: Design, Taste and Society 18751900, Melbourne: Melbourne University Press, 2000.

'Arabesques of Beauty: Cullis Hill, the 9 by 5 Impression Exhibition, Decorative Decor and Painting', The La Trobe Journal, 2014, 82-101.

'One of the Greatest Sights of the World': Herr Carl Kahler's Paintings and Prints, 'The Melbourne Cup Series, 1887-89', The La Trobe Journal, 86, December $2010,83$.

Muir, Brian, 'Sydney Lough Thompson, 1877-1973', Robert McDougall Art Gallery Survey, 14, 1976.

Murray-Oliver, Anthony, 'Art in New Zealand', New Zealand's Heritage, 3, 1972, 1194 1199.

Nadelhaft, Janice, 'Punch and the Syncretics: An Early Victorian Prologue to the Aesthetic Movement', Studies in English Literature 1500-1900, 15, 4, 1975, 627-640. 
Nairn, James M., 'Art and Artists', 'Decorative Art', Otago Witness, 7 August 1890, 4142.

'The Progress of Art in New Zealand', NZM, 6 October 1892, 11.

,'Some Notes on Landscape Painting', NZM, 23 April 1896, 13.

National Art Gallery, Nairn and his Associates, Supplement, Wellington: Madison Print Ltd., 1975.

National Art Gallery, Raymond McIntyre; Works in the National Collection curated by M. N. Day (exhibition catalogue), Wellington, 1972.

National Portrait Gallery (Great Britain), Early Victorian Portraits (by Richard Ormond), London: H. M. S. O., 1973.

Neiswander, Judith A., The Cosmopolitan Interior, Liberalism and the British Home, 1870-1914, Haven \& London: Yale University Press, 2008.

Newell, Christopher, The Grosvenor Gallery Exhibitions: Change and Continuity in the Victorian Art World, Cambridge, U. K. and New York, U. S. A.: Cambridge University Press, 1995.

New Zealand Art Students' Association of Auckland: Constitution and Rules, Exhibition Regulations, and Lists of Prizes, for the Year 1884, Auckland: Wilson \& Horton, 1884.

New Zealand Art Students' Association of Auckland for the Year 1884, First Annual Report, Auckland: Wilson \& Horton, 1885.

New Zealand Art Students' Association of Auckland, Catalogue of the Third Annual Exhibition at Milne \& Choyce's Buildings, Queen Street Auckland, Auckland: Wilson \& Horton, 1886.

Notman, Robyn, Lynda Cullen and Dunedin Public Art Gallery, Beloved: Works from the Dunedin Public Art Gallery, Dunedin: Dunedin Public Art Gallery, 2009.

Nunn, Pamela Gerrish, Victorian Women Artists, London: The Women’s Press, 1987.

Oakley, John, Paintings of Canterbury 1840-1890, Wellington: A. H. \& A. W. Reed Publishing, 1969.

Official Catalogue of the New Zealand and South Seas Exhibition 1889-90, (compiled by D. H. Hastings), Wellington, Government Printer, 1891.

O'Keeffe, A. H., 'Art in Retrospect: Earlier Dunedin Days, Paint and Personality', Art in New Zealand, 47, March 1940, 156-62.

O'Neill, Morna, Walter Crane: the Arts and Crafts, Painting, and Politics, 1875-1890, New Haven: Yale University Press, 2010. 
Packwood, George Earl S., Nairn and his Associates, Selected from Works in the Collection of the National Art Gallery, 4, Wellington: National Art Gallery, 1969.

Parry, Linda, 'Aestheticism', in Michael Snodin and John Styles (eds.), Design and the Decorative Arts: Britain 1500-1900, London: V\&A Publishing, 2001, 358-59.

Pater, Walter, The Renaissance, Studies in Art and Poetry, London: Macmillan and Co. Ltd., 1900.

Payne, John, Framing the Nineteenth Century: Picture Frames 1837-1935, Melbourne: Peleus Press and NGV, 2007.

Pearce, Barry, 'Colonial Eyes' in Australian Art in the Art Gallery of New South Wales, Sydney: Art Gallery of New South Wales, 2000, 17-18.

Pennell, Elizabeth and Joseph Pennell, The Life of James McNeill Whistler, London: W. Heinemann, 1908.

Petersen, Anna K. C., New Zealanders at Home: A Cultural History of Domestic Interiors 1814-1914, Dunedin: University of Otago Press, 2001.

'The European Use of Māori Art in New Zealand c. 1890-1914', At Home in New Zealand: History, Houses, People, Barbara Brookes (ed.), Wellington: Bridget Williams Books, 2000.

Phillips, Jock and Chris Maclean, Light of the Past: Stained Glass Windows in New Zealand Houses, Melbourne and Auckland: Oxford University Press, 1983.

Platts, Una, Nineteenth-Century New Zealand Artists: A Guide and Handbook, Christchurch: Avon Fine Prints, 1979.

Pound, Francis, 'A Battle of the Critics: The Concept of the Avant-Garde comes to New Zealand', Art New Zealand, 28, Winter 1983, 24-27.

Frames on the Land: Early Landscape Painting in New Zealand, Auckland: William Collins Publishers Ltd, 1983.

Prettejohn, Elizabeth, Art for Art's Sake: Aestheticism in Victorian Painting, New Haven and London: Yale University Press, 2007.

Renwick, William (ed.), Creating National Spirit: Celebrating New Zealand's Centennial, Wellington: Victoria University Press, 2004.

Rice, Geoffrey, W. H. Oliver, and B. R. Williams, The Oxford History of New Zealand, 2 ed., Auckland, N.Z.: Oxford University Press, 1992.

Rice, Rebecca, 'The Art of Photography at Nineteenth-Century International Exhibitions', New Zealand Journal of Photography, 63, 2007, 8-12. 
'The Courage of her Convictions', New Zealand Books: A Quarterly Review, 25, $2015,16$.

Schiff, Joel L., Grace Joel: An Impressionist Portrait, Dunedin: Otago University Press, 2014

Schofield, G. H., (ed.), A Dictionary of New Zealand Biography (2 vols.), Department of Internal Affairs, Wellington, 1940.

Sealy, H. P., 'L' Académie Julian in Paris', New Zealand Illustrated Magazine, 5, 1 October 1901, 17-22.

,'In the Studio: Mr C. F. Goldie's Work', New Zealand Illustrated Magazine, 6, 1 November 1901, 144-149.

Shelley, James, 'Sydney Lough Thompson: Painter', Art in New Zealand, 31, March 1936, 129-39.

Singer, Richard Arnold, 'Mr C. F. Goldie and his Pictures', Triad, 11, 9, 1 December $1903,10-12$.

Smith, Alison, The Victorian Nude: Sexuality, Morality and Art, Manchester, U. K. and New York, U. S. A.: Manchester University Press, 1996.

Smith, Bernard W., Place, Taste and Tradition: a Study of Australian Art since 1788, Melbourne: Oxford University Press, 1979. (with additions by Terry Smith), Australian Painting, 1788-1990, Melbourne: Oxford University Press, 1991.

Smith, Bill and Selina Skipwith, A History of Scottish Art, London: The Fleming-Wyfold Art Foundation, 2003.

Spencer, Robin, The Aesthetic Movement: Theory \& Practice, London: Studio Vista Publishing, 1972.

Stacpoole, John, 'Steele, Louis John', Dictionary of New Zealand Biography, Te Ara Encyclopedia of New Zealand, 2014. http://www.teara.govt.nz/en/biographies/ 2s42/steele-louis-john. Accessed: 10 June 2015.

Staley, Allen, The New Painting of the 1860s: Between the Pre-Raphaelites and the Aesthetic Movement, New Haven: Yale University Press, 2011.

Surtees, Virginia, Coutts Lindsay 1824-1913: The Grosvenor Gallery, Norwich U. K.: Michael Russell, 1993.

Taylor, Alister and Jan Glen, C. F. Goldie 1870-1947: His Life and Painting, Martinborough: A. Taylor, 1977. 
Taylor, Alex, Perils at the Studio: Inside the Artistic Affairs of Bohemian Melbourne, Melbourne: Australia Scholarly Publishing and State Library of Victoria, 2007.

Tennyson, Alfred, 'The Palace of Art', Poetical Works, London: Macmillan \& Co., 1916, 44-49.

The Scottish Art Review, 1, Glasgow and London: Elliot Stock, June 1888 - May 1889. https://archive.org/stream/scottishartrevie01unse\#page/n5/mode/2up. Accessed: 23 May 2015.

Thomson, G. M., The Naturalisation of Animals \& Plants in New Zealand, Cambridge: Cambridge University Press, 1922.

Thompson, Nancy and Joan Brickell, Biographies of the Artists Represented in the Olveston Collection, Dunedin: Theomin Gallery, 1985.

Thoms, Albie, Bohemians in the Bush: The Artists' Camps of Mosman, Sydney: Art Gallery of New South Wales, 1991.

Tizard, R., The Auckland Society of Arts 1870-1970: A Centennial History, Auckland: Business Printing Works, 1970.

Todd, Pamela, The Pre-Raphaelites at Home, London: Pavilion Books, 2001.

Tomory, P. A., (ed.), New Zealand Art: Painting 1827-1967, Wellington: A. H \& A. W. Reed Publishing, 1968.

Tomory, P. A. and Anne Kirker, British Painting 1800-1990: In Australian and New Zealand Public Collections, Sydney: The Beagle Press, 1997.

Topliss, Helen, The Artists' Camps: Plein Air Painting in Melbourne 1885-1898, Melbourne: Monash University Gallery and The Visual Arts Board of the Au stralia Council, 1984.

Tripe, M. E. R., 'James McLauchlan Nairn: Some Personal Reminiscences', Art in New Zealand, 1, December 1928, 105-107.

Trodd, Colin and Stephanie Brown, Representations of G. F. Watts: Art Making in Victorian Culture, London, U. K. and Burlington, U. S. A.: Ashgate Publishing, 2004.

Trumble, Angus, Love and Death: Art in the Age of Queen Victoria, Adelaide: Art Gallery of South Australia, 2007.

Turner, John B. (ed.), Nineteenth-Century New Zealand Photographs, Govett-Brewster Art Gallery, New Plymouth, 1970. 
Tyler, Linda. 'McIntyre, Raymond Francis', Dictionary of New Zealand Biography, Te Ara, Encyclopedia of New Zealand. http://www.TeAra.govt.nz/en/biographies/ 3m11/mcintyre-raymond-francis. Accessed: 16 September 2015.

Unidentified 'Correspondent', 'A Gossip about Studios', The Architect, 11, 28 March 1874, 174-75.

Unidentified author, 'The Late Mr J. M. Nairn by One of his Pupils', New Zealand Illustrated Magazine, 1 May 1904, 135-138.

Vaughan, Gerard and Veronica Angelatos, New Acquisitions, 31, Melbourne: National Gallery of Victoria, 2003.

Vial, Jane, Bohemians of the Brush, Pumpkin Cottage Impressionists, Upper Hutt: Expressions Arts \& Entertainment Centre, 2010.

'Nairn, James McLauchlan', The Dictionary of New Zealand Biography, 2, 18701900, Wellington: Department of Internal Affairs, 1993.

'Tom Roberts and the New Zealand Avant-Garde', Art New Zealand, 76, 1995, 80-84.

Van Gogh Museum, Amsterdam, 'Vincent van Gogh Letters', September 1888. http://vangoghletters.org/vg/letters/let682/letter.html. Accessed: 14 January 2016.

Weinberg, H. Barbara, 'James McNeill Whistler (1834-1903)', Heilbrunn Timeline of Art History, New York: The Metropolitan Museum of Art, 2010.

http://www.metmuseum.org/toah/hd/whis/hd whis.htm. Accessed 4 January 2016.

, The Lure of Paris: Nineteenth-Century American Painters and their French Teachers, New York: Abbeville Press, 1991.

Weisinger, Véronique et al., Paris Bound: American in Art Schools 1868-1918, (exh. catalogue), Paris: Réunion des Musées Nationaux, 1990,

Wilde, Oscar, 'The Grosvenor Gallery', Dublin University Magazine, July 1877, 118126.

Wilson, Charles, 'James McLachlan [sic] Nairn', Sydney: Art in Australia: A Quarterly Magazine, 5, August 1923, unpaginated.

Wilson, Elizabeth, 'Edward Friström: Interpretations of the Landscape', Art New Zealand, 19, 1981, 42-45.

Wilson, T. L., Rodney, Petrus van der Velden (1837-1913), Wellington, A. H. \& A. W. Reed, 1976. 
Wilton, Andrew and Robert Upstone (eds.), The Age of Rossetti, Burne-Jones \& Watts, Symbolism in Britain 1860-1910, London: Tate Gallery Publishing, 1997.

Wolfe, Richard, 'Antipodean Bohemian: Reacting to Impressionism in New Zealand', Art New Zealand, 150, Winter 2014, 108-15.

Young, Andrew McLaren, Margaret MacDonald, Robin Spencer, and Paul Mellon Centre for Studies in British Art, The Paintings of James McNeill Whistler, New Haven: Yale University Press, 1980. 


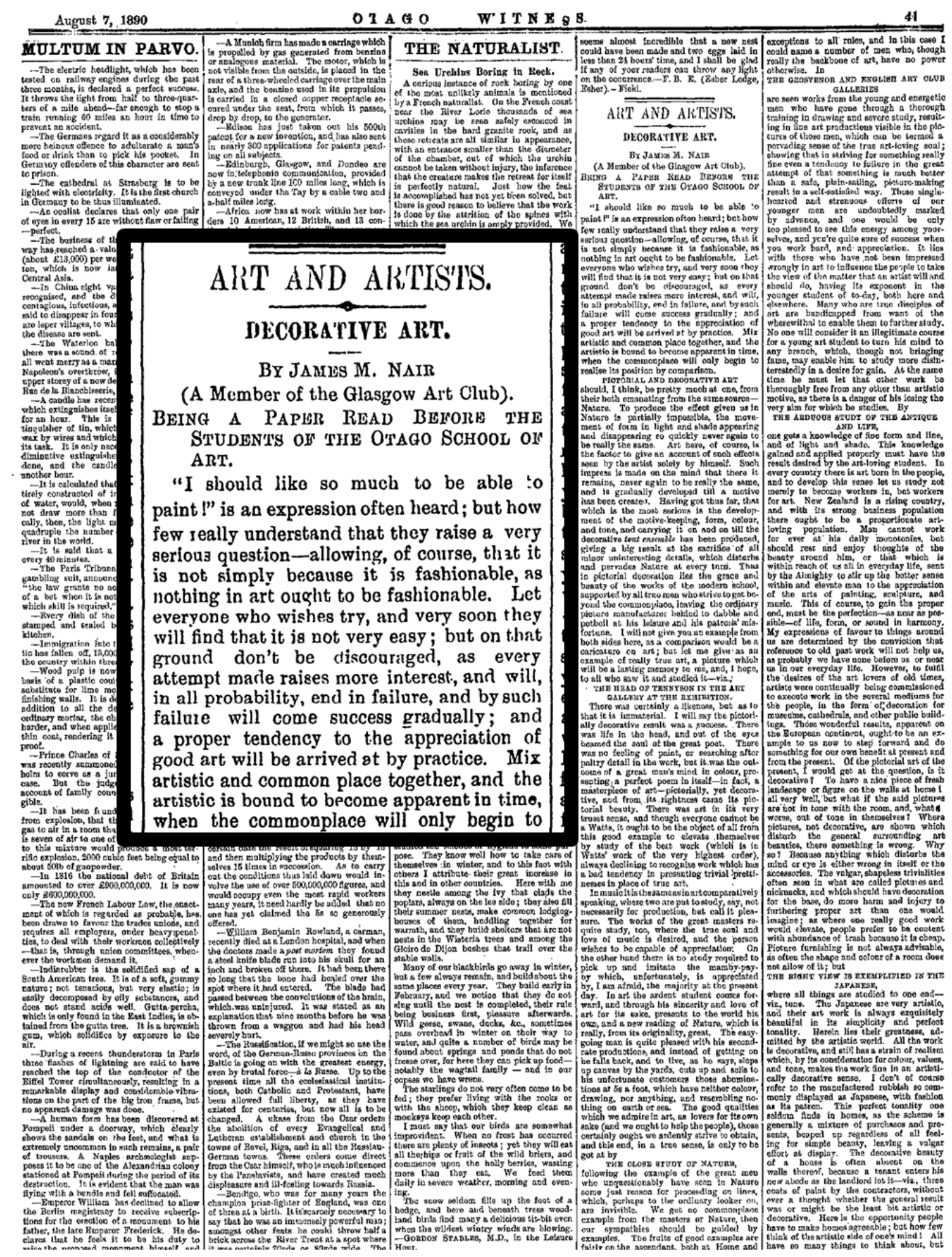

Plate 42: James M. Nairn, 'Art and Artists', 'Decorative Art', Otago Witness, 7 August 1890, 41-42.

[Inset] Detail of the transcript of Nairn's first lecture in New Zealand. 


\section{APPENDIX:}

\section{J. M. NAIRN’S ‘DECORATIVE ART’, 1890, 41-42.}

"I should like so much to be able to paint!" is an expression often heard; but how few really understand that they raise a very serious question - allowing of course, that it is not simply because it is fashionable, as nothing in art ought to be fashionable. Let everyone who wishes try, and very soon they will find that it is not very easy; but on that ground don't be discouraged, as every attempt made raises more interest, and will, in all probability, end in failure, and by such failure will come success gradually; and a proper tendency to the appreciation of good art will be arrived at by practice. Mix artistic and common place together, and the artistic is bound to become apparent in time, when the commonplace will only begin to realise its position by comparison.

PICTORIAL AND DECORATIVE ART should, I think, be pretty much at one, from their both emanating from the same source - Nature. To produce the effect given us in Nature is partially impossible, the movement of form in light and shade appearing and disappearing so quickly never again to be really the same. Art here, of course, is the factor to give an account of such effects seen by the artist solely by himself. Such impress is made on the mind that there it remains, never again to be really the same, and is gradually developed till a motive has been created. Having got thus far, that which is the most serious is the development of the motive-keeping, form, colour and tone, and carrying it on and on till the decorative tout ensemble has been produced, giving a big result at the sacrifice of all minor uninteresting details, which disturbs and pervades Nature at every turn. Thus in pictorial decoration lies the grace and beauty of the works of the modern school, supported by all true men who strive to get beyond the commonplace, leaving the ordinary picture manufacturer behind to dabble and potboil at his leisure and his patrons' misfortune. I will not give you an example from both sides here, as a comparison would be a caricature on art; but let me give as an example of really true art, a picture which will be a lasting memory to me, and, I hope, to all who saw it and studied it - viz., THE HEAD OF TENNYSON IN 
THE ART GALLERY AT THE EXHIBITION. There was certainly a likeness, but as to that it is immaterial. I will say the pictorially decorative result was a success. There was life in the head, and out of the eyes beamed the soul of the great poet. There was no feeling of paint, or searching after paltry detail in the work, but it was the outcome of a great man's mind in colour, presenting a perfect poem in itself - in fact, a masterpiece of art - pictorially, yet decorative, and from its rightness came its pictorial beauty. There was art in its very truest sense, and though everyone cannot be a Watts, it ought to be the object of all from this good example to elevate themselves by study of the best work (which is in Watts' work of the very highest order), always declining to recognise work which has a bad tendency in presenting trivial prettinesses in place of true art.

In music it is the same as in art comparatively speaking, where two are put to study, say, not necessarily for production, but call it pleasure. The works of the great masters require study, too, where the true soul and love of music is desired, and the person wishes to be capable of appreciation. On the other hand there is no study required to pick up and imitate the mamby-pay-by which, unfortunately, is appreciated by, I am afraid, the majority at the present day. In art the ardent student comes forward through his sincerity and love of art for its sake, presents to the world his own, and a new reading of Nature, which is really, from its originality, great. The easy-going man is quite pleased with his second-rate productions, and instead of getting on he falls back, and to live, as he says, slops up canvas by the yards, cuts up and sells to his unfortunate customers those abominations at $5 \mathrm{~s}$ a foot, which have neither colour, drawing, nor anything, and resembling nothing on earth or sea. The good qualities which we admire in art, as lovers for its own sake (and we ought to help the people), those certainly ought we ardently strive to obtain, and this end, in a true sense, is only to be got at by

THE CLOSE STUDY OF NATURE, following the example of the great men who unquestionably have seen in Nature some just reason for proceeding on lines, which, perhaps to the ordinary looker on, are invisible. We get no commonplace example from the masters or Nature, then our sympathies should be guided by examples. The fruits of good examples are fairly on the ascendant, both at Home and abroad, and it only requires such magnetic influence carried a step further by ourselves, and we 
would have much more refined taste in both pictorial and decorative work, which in time must tell on the minds of the rising generation, by giving them an insight to art and her mission. The example of the Royal Academies of England and Scotland has not been fruitful, because it is and has been bad. This is easy enough to see by the direct opposition arising of late years. The criticism has been fast and furious over it, but no change has taken place, nor is it likely that any change will take place, as "possession is nine points of the law." Those institutions have closed their doors to the advances of art with the rising generation, but keep sailing over the calm sea of fashionable picture making. Young spirit and power has been kept out, rejected, or, when admitted skied. Why? Because true to themselves, the young men would not for art's sake follow in the steps of men whom they sincerely thought were not true, either to themselves or art. Of course there are exceptions to all rules, and in this case I could name a number of men who, though really the backbone of art, have no power otherwise. In THE GROSVENOR AND ENGLISH ART CLUB GALLERIES are seen works from the young and energetic men who have gone through a thorough training in drawing and severe study, resulting in fine art productions visible in the pictures of those men, which can be termed a pervading sense of the true art-loving soul; showing that in striving for something really fine even a tendency to failure in the great attempt of that something is much better than a safe, plain-sailing, picture making result in a self-satisfied way. Those single-hearted and strenuous efforts of our younger men are undoubtedly marked by advance, and one would be only too pleased to see this energy among yourselves, and you're quite sure of success when you work hard, and appreciation. It lies with those who have not been impressed wrongly in art to influence the people to take the view of the matter that an artist will and should do, having its exponent in the younger student of to-day, both here and elsewhere. Many who are true disciples of art are handicapped from want of the wherewithal to enable them to further study. No one will consider it an illegitimate course for a young art student to turn his mind to any branch, which, though not bringing fame, may enable him to study more disinterestedly in a desire for gain. At the same time he must let that other work be thoroughly free from any other than artistic motive, as there is a danger of his losing the very aim for which he studies. 
By THE ARDUOUS STUDY OF THE ANTIQUE AND LIFE, one gets a knowledge of fine form and line, and of light and shade. This knowledge gained and applied properly must have the result desired by the art-loving student. In every country there is art born in the people, and to develop this sense let us study not merely to become workers in, but workers for art. New Zealand is a rising country, and with its strong business population there ought to be a proportionate art-loving population. Man cannot work for ever at his daily monotonies, but should rest and enjoy thoughts of the beauty around him, or that which is within reach of us all in everyday life, sent by the Almighty to stir up the better sense within and elevate man to the appreciation of the arts of painting, sculpture, and music. This of course, to gain the proper end, must be the perfection - as near as possible - of life, form, or sound in harmony. My expressions of favour to things around us are determined by the conviction that reference to old past work will not help us, as probably we have none before us or near us in our everyday life. However, to fulfil the desires of the art lovers of old times, artists were continually being commissioned to execute work in the several mediums for the people, in the form of decoration for museums, cathedrals, and other public buildings. Those wonderful results, apparent on the European continent, ought to be an example to us now to step forward and do something for our own benefit at present and from the present. Of the pictorial art of the present, I would get at the question, is it decorative? To have a nice piece of fresh landscape or figure on the walls at home i[s] all very well, but what if the said pictures are not in tone with the room, and, what [s] worse, out of tone in themselves? Where pictures, not decorative, are shown which disturb the general surrounding art beauties, there is something wrong. Why so? Because anything which disturbs the mind or eye is either wrong in itself or the accessories. The vulgar, shapeless trivialities often seen in what are called pictures and nicknacks, and which should have decoration for the base, do more harm and injury to furthering proper art than one would imagine; as where one really good work would elevate, people prefer to be content with abundance of trash because it is cheap. Picture furnishing is not always advisable, as often the shape and colour of a room does not allow of it; but THE RIGHT VIEW IF EXEMPLIFIED IN THE JAPANESE, where all things are studied to one end - viz., tone. The Japanese are very artistic, and their artwork is always exquisitely beautiful in its simplicity and perfect tonality. Herein lies their greatness, admitted by the artistic world. All the work is 
decorative, and still has a strain of realism which, by its consideration for colour, values and tone, makes the work fine in an artistically decorative sense. I don't of course refer to the manufactured rubbish so commonly displayed as Japanese, with fashion as its patron. This perfect tonality one seldom finds in homes, as the scheme is generally a mixture of purchases and presents, heaped up regardless of all feeling for simple beauty, leaving a vulgar effort at display. The decorative beauty of a house is often absent on the walls thereof, because a tenant enters his new abode as the landlord let it - viz., threes coats of paint by the contractors, without ever a thought whether the general result was or might be the least bit artistic or decorative. Here is the opportunity people have to make homes agreeable; but how few think of the artistic side of one's mind! All have so many things to think about, but generally excuse themselves by pleading that times are too hard, as if it were not as cheap to have artistic work well done as commonplace. Advance is made daily by a few artistic painters, who look upon a room as a picture of health and comfort; and this is due to art principles being their aim. By this sympathy existing between parties and their work, some really fine results come to light, and this is only the natural outcome of perseverance in aiming at true artistic art. Of course the tendency of the public to be content with rubbishy show having been flooded upon them, is removed if we go to the source - viz., the painter, potter, carver, or iron-worker, who produce work which from its utter disregard for art can bring no pleasure to them in production, or no lasting pleasure to the user. To those who are studying (let it be in whichever branch) I advise THE CULTIVATION OF A DESIRE TO BE GENUINE, so that giving to the world your mind in any form of art, you would know that you have done it sincerely for the elevation of the minds of the community, and would have as your reward the most worthy form of criticism and praise - that of your brother worker. In referring to decoration as a help to education, I quote the words of Walter Crane, "We are thinking more of our shop windows than the windows of our minds." Very true, as we seldom see in schools, for instance (where the rising generation are plodding through the monotony of books), art work which, perhaps, from its archaeolo gical, historical, idealistic, or realistic importance would tend to stimulate the young mind in the fine arts. In public buildings also is the absence of such work felt, but in schools more especially. I think there should be examples of subject decoration by really competent men, carried out according to a scheme suited to the education of the mind. Whether 
pastoral, peasant, or historical, these would help the student both artistically and morally. Schools, or those under whose government they are should really take a step in furthering the art education of which I speak by giving encouragement to young art workers. By offering a prize, say, the students would be led to submit designs, and, with the hope of their being utilised further on, would spur them on to better efforts. How many people could give a $£ 10$ note for public art benefit, and enjoy it, who throw money away trivially, and never through their fears and hopes expect to see any return; whereas they could do a vast amount of good by taking art e ducation in hand and distributing benefits among those to whom fate had not been so considerate, thereby enjoying it with those whom they had benefitted. In this impression of little truths, however, I'd have you bear in mind that were the scheme ever to take shape in any of your hands, the first and leading desire in the development should be to let nothing but what is really instructive with artistic vitality be selected to compose the decoration of any place; as were the paintings wanting in artistic intelligence, and judiciously schemed in tone, colour, and form, the results would be worse than nothing but bare walls and windows. The application of each man's peculiar sentiments in this way would be presented to us, and through time, no doubt, the technical ability showing would lead to a fixed selection for the decoration of whichever public or private apartment there was in view. 